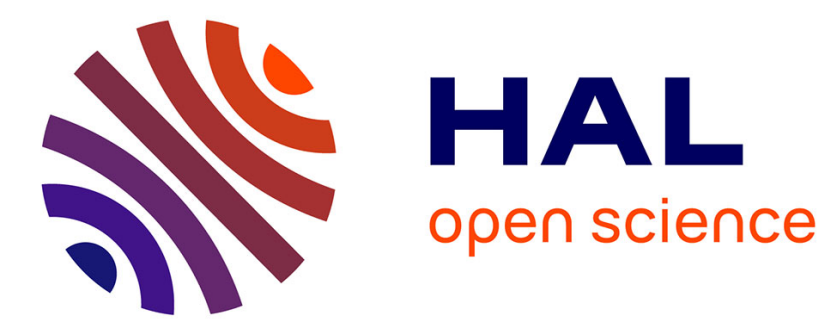

\title{
Commodity returns co-movements: Fundamentals or "style" effect?
}

Philippe Charlot, Olivier Darné, Zakaria Moussa

\section{To cite this version:}

Philippe Charlot, Olivier Darné, Zakaria Moussa. Commodity returns co-movements: Fundamentals or "style" effect?. 2014. hal-01093631

\section{HAL Id: hal-01093631 \\ https://hal.science/hal-01093631}

Preprint submitted on 10 Dec 2014

HAL is a multi-disciplinary open access archive for the deposit and dissemination of scientific research documents, whether they are published or not. The documents may come from teaching and research institutions in France or abroad, or from public or private research centers.
L'archive ouverte pluridisciplinaire HAL, est destinée au dépôt et à la diffusion de documents scientifiques de niveau recherche, publiés ou non, émanant des établissements d'enseignement et de recherche français ou étrangers, des laboratoires publics ou privés. 
EA 4272

\title{
Commodity returns co-movements: Fundamentals or "style" effect?
}

\author{
Philippe Charlot* \\ Olivier Darné* \\ Zakaria Moussa*
}

$2014 / 30$

$\left(^{*}\right)$ LEMNA, Université de Nantes

\section{Laboratoire d'Economie et de Management Nantes-Atlantique Université de Nantes \\ Chemin de la Censive du Tertre - BP 52231 44322 Nantes cedex 3 - France \\ www.univ-nantes.fr/iemn-iae/recherche}

Tél. +33 (0)2 40141717 - Fax +33 (0)2 40141749 


\title{
Commodity returns co-movements: Fundamentals or "style" effect?
}

\author{
Philippe Charlot* Olivier Darné $^{\dagger}$ Zakaria Moussa ${ }^{\ddagger \S}$
}

\begin{abstract}
This paper investigates dynamic correlations both across commodities and between commodities and traditional assets, such as equities and government bonds, using the Regime Switching Dynamic Correlation (RSDC) model. In particular, this paper assesses the dynamics of 32 daily commodity futures returns, spanning a period from May 28, 2003, to June 04, 2014, in the light of economic and financial events before and after the mid-2007 financial crisis. There are three major findings. First, prior to the financial crisis, we detect stronger correlation among the wide range of commodities used in the analysis, indicating that the financialization process started impacting commodity price movements from mid-2005. Between commodities taken as an asset class and traditional asset classes our results generally show very weak commodity-equity and commodity-bond correlations prior to the Lehman Brother collapse. This can be explained by the "style "effect theory that correlations between different asset classes in a portfolio weaken. Second, during the financial crisis, correlations both across commodities and between commodities and equities increase dramatically, with a regime change which coincides exactly with the demise of Lehman Brothers on September 15, 2008. This suggests that a strong commodity-equity integration was temporarily masked by the "style "effect. However, commodity-bond correlations switch to a strongly negative regime, showing that government bonds were considered as refuge securities. Third and most importantly, the new and original finding here is the temporary nature of the financial crisis effect identified, as correlations both across commodities and between commodities and traditional assets revert to pre-crisis level from April 2013. This highlights the impact of the financial-based factors on commodity price movements.
\end{abstract}

JEL classification: C22; G01; G10; G12; Q4

Keywords: Financialization; Style effect; Commodities; Cross-market linkages; Financial crisis; RSDC model

\footnotetext{
*LEMNA, University of Nantes, France, philippe.charlot@univ-nantes.fr

${ }^{\dagger}$ LEMNA, University of Nantes, France, olivier.darne@univ-nantes.fr

${ }^{\ddagger}$ Corresponding author. LEMNA, University of Nantes, France, zakaria.moussa@univ-nantes.fr.

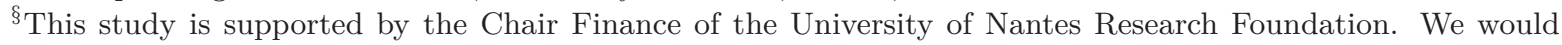
like to thank participants at the seminar of Banque de France and the 31st Spring International Conference of the French Finance Association for their valuable feedback.
} 


\section{Introduction}

The most attractive aspect of commodity investments is that they offer diversification benefits both by hedging against inflation and by improving the risk-adjusted performance of a mixedasset portfolio due to the low, or even negative, correlations between this alternative class of assets and traditional assets, such as equities or bonds (Gorton and Rouwenhorst, 2006; Chong and Miffre, 2010; Daskalaki and Skiadopoulos, 2011; Büyükşahin et al., 2010; Büyükşahin and Robe, 2014). As equities performed poorly for two years following the 2000 burst of the Internet bubble, these alternative assets were therefore increasingly included in the strategic portfolio allocation process by institutional investors, particularly pension funds.

Investable commodity indices offer wide exposure to different commodity futures in different sectors of commodity markets, allowing index investors to reduce the risk of their overall investment portfolios whilst avoiding the problems involved in managing the physical goods. Commodity index swap dealers, having short positions with their investors, must hedge their positions by taking long positions on the underlying commodity futures. The inflow of index investors initiates the commodity financialization process $^{1}$.

Before the 2007-2008 financial crisis, decreases in equity prices were generally accompanied by increases in commodity prices, reflecting a certain autonomy between commodity and equity markets. A new feature that emerged from the recent financial crisis was similar trends in equity and commodity markets. The synchronized sharp decline in equity and commodity prices in 2008 indicates increasing correlations between the two markets. Tang and Xiong (2010, 2012) stressed the importance of financialization in increasing the correlation both amongst seemingly unrelated commodities and between commodity and equity returns; the financial crisis simply further magnified this effect. This raises the question of the role of commodities as a diversification tool. The aim of this paper is twofold. Firstly, we analyze correlations both across commodity futures and between commodity futures and traditional assets, focusing on commodity-equity correlation. Secondly, we measure the impact of the 2007-2008 financial crisis, assessing whether the crisis caused a temporary or a permanent shift in the correlation trend, thereby providing insights into commodity price movements during recent years.

Existing theories on correlations across indexed assets show how fundamentally uncorrelated assets may move together when they become index constituents. According to the "style investment"theory of Barberis and Shleifer (2003) and Barberis et al. (2005), constructed for stock markets and adapted by Basak and Pavlova (2013) to commodities, commodity index investment increases correlations among seemingly unrelated commodities in commodity index. This increases homogeneity among indexed commodities, leading them to be accepted as a distinct asset class or "style", like equity and fixed interest asset classes. However, commodity index investments may have two counteracting effects on co-movements between commodity indices, and therefore on index constituents and traditional assets like stocks, depending on index investors' rebalancing strategies and the composition of their portfolios. On the one hand, commodity index trading can act as a channel leading to higher correlations with other assets in a portfolio. As index investors, having incentives to maintain their portfolio diversification level, rebalance their portfolios between commodities and stocks when a shock alters portfolio weights, correlations among the different assets increase (Basak and Pavlova (2013)). On the other hand, to be recognized as an asset class, commodity futures need to exhibit a sufficiently low correlation with

\footnotetext{
${ }^{1}$ The World Bank estimates as much as $\$ 325$ billion worth of assets are under the management of the hedge fund industry, about nine times higher than in the last decade (World Bank Commodity Market outlook 2012,...2014). Moreover, the total amount invested in commodity derivatives in the over-the-counter market of securities firms or banks of the leading 11 developed countries rapidly increased after 2005 from $\$ 1400$ trillion (base for notional value) in December 2004 to $\$ 9000$ trillion in December 2007 (BIS, Regular OTC Derivatives Market). Also, a CFTC staff report (2008) estimates that the total amount invested in commodity indices by non-commercial participants increased from $\$ 15$ billion in 2003 to $\$ 200$ billion in 2008 .
} 
other asset classes; this is one of the qualitative criteria (in addition to sufficient market capitalization, availability of pricing and investability). Barberis and Shleifer (2003) consider this weak correlation as a consequence of the "style" competition caused by the externality generated by switcher investors: switching portfolio composition between commodity indices and stocks leads to a weak, even negative, correlation between the two competing asset classes. To sum up, index investments can have a positive as well as a negative impact on commodity-equity correlations, the overall co-movement reaction depending on whether positive or negative effects prevail.

However, in times of financial crisis, regardless of these theoretical index investment effects, correlations may sharply increase between different asset classes included in investors' portfolios, particularly between commodities and equities, the largest part of investors' portfolios (Kyle and Xiong, 2001; Brunnermeier and Pedersen, 2009). When a market collapses, investors, particularly leveraged, are drawn into a "loss spiral" (Brunnermeier and Pedersen (2009)) and sell risky assets to raise liquidity, causing falls in unrelated asset returns. ${ }^{2}$ Although again unrelated to fundamentals, this common effect sharply increases correlations, both across commodities as a distinct asset class and between commodities and other asset classes. This is in line with the Büyükşahin et al. (2010) notion of a "market of one", postulating an increase in co-movements among unrelated asset classes during turbulent periods. Relatedly, Singleton (2012) documents a significant contribution by flows from institutional investors to the 2008 boom/bust in oil prices.

Numerous empirical studies examine the link between commodity and equity markets before the financial crisis. There seems to be broad consensus that correlations between these two assets are weak and generally follow a decreasing trend, suggesting that commodity futures do improve diversification benefits for investors. Jensen et al. (2000) and Erb and Harvey (2006) report that the correlation between commodity futures returns and the S\&P 500 is weak and even negative for some commodities. Chong and Miffre (2010) apply the multivariate dynamic conditional correlation (DCC) GARCH approach introduced by Engle (2002) on 25 commodities and seven equity assets (within the S\&P 500 index), spanning the period from December 12, 1980 to December 27, 2006. They find that the conditional correlations between commodity and S\&P500 returns fall over time, a sign that commodity futures have become better tools for strategic asset allocation. Conversely, Choi and Hammoudeh (2010) study the correlation between five commodities (Brent oil, WTI oil, copper, gold and silver) and the S\&P 500 index, using the DCC GARCH model, for the period between January 2, 1990 and May 1, 2006. Their results show that equity-commodity correlations started to rise as early as 2003 and hence diversification benefits declined.

Büyükşahin et al. (2010) study the correlation between the S\&P 500 and six commodity sub-indices, namely, Agriculture, Energy, Industrial Metals, Livestock, Non-Energy and Precious Metals. They treat structural breaks exogenously by using subsample analysis for the periods June 1991-May 1997, June 1997-May 2003 and June 2003-November 2008. They contend that, even though the co-movements between equities and commodities increased substantially during the financial crisis, they remained lower than their peaks in the previous decade, suggesting that commodities retained their role as a diversification tool. These findings are consistent with those in Büyükşahin and Robe (2014) using updated data from January 1991 to February 2010.

In order to take into account correlation regime changes, Silvennoinen and Thorp (2013) apply a bivariate conditional volatility and correlation dynamics model (DSTCC-GARCH), developed by Silvennoinen and Teräsvirta (2009). They include 24 individual commodity futures returns along with major equity indices in the U.S. and Europe from May 1990 to July 2009, plus US government bonds, and use either time calendar or the implied volatility index (VIX) as transition variables governing the correlation switch. Contrary to Büyükşahin et al. (2010), Büyükşahin and Robe (2014) and Chong and Miffre (2010), their main findings are in line with those of

\footnotetext{
${ }^{2}$ Closely related to the "loss spiral" theory of Brunnermeier and Pedersen (2009), Kyle and Xiong (2001) propose a model explaining that in times of financial crisis, financial intermediaries experience wealth effects reducing their risk-bearing capacity and pushing them to sell all types of assets held in their portfolios.
} 
Tang and Xiong (2010, 2012). They support the rising trend hypothesis, i.e. that all commodity correlations with stock indices, except for gold, start to increase gradually well before the financial crisis, reflecting the effect of financial integration between markets, and grow sharply during the turbulent period of the financial crisis. However, correlation with the bond market is generally weak and constant over the sample data, being particularly low, or even switching to a negative regime, for Industrial Metals.

Our paper contributes to this rich debate by extending previous studies in two principal respects. First, from a methodological perspective, a novel and distinctive feature of the paper is that it adopts the Regime Switching for Dynamic Correlations (RSDC) model of Pelletier (2006), estimated using the EM (Expectation-Maximization) algorithm. Both in DSTCC, applied by Silvennoinen and Thorp (2013), and in RSDC, dynamic correlations can switch between two or more constant correlation matrices, depending on the number of regimes. The main difference between the two approaches lies in the assumption concerning the mechanism that governs the switch. The DSTCC assumes a deterministic switch based on a conditional transition function which includes smoothing and localization parameters and either deterministic or stochastic transition variables. The problem with such an approach is that the regime switch depends on the transition variable selected. This problem does not arise with the RSDC, however, as it assumes that the switch between constant correlation matrices is established through an underlying hidden stochastic process with a first order Markov chain. Moreover, the DSTCC model encounters major numerical problems when estimated with a large number of series, whereas the RSDC can be applied to a large dataset, especially when it is estimated using an EM algorithm. The ease with which the RSDC performs large-scale estimations allows us to model series in groups, whereas the DSTCC would only be able to deal with bivariate estimations. Second, applying the EM algorithm to estimate the model allows us to exploit a more extensive data set, covering the period of the 2007-2008 financial crisis. While most papers use either commodity indices or a few individual commodity futures prices, we consider daily data for the four major commodity indices and 32 individual commodity futures returns, along with stock and bond returns, spanning a period from May 28, 2003, to June 04, 2014. Our sample period allows for analysis to be performed before and after the financialization as well as during the financial crisis and the subsequent changes, so as to clearly distinguish between financialization-related and crisis-related effects on the change in correlation trend.

Our main findings can be summarized as follows. First, before the financial crisis, our results confirm the theoretical findings of both "style effect"and asset management allocation: we detect stronger integration among the large selection of commodities used in the analysis. Moreover, as in Tang and Xiong $(2010,2012)$, we find that correlations between Non-Energy commodities and WTI started to increase well before the recent financial crisis, indicating that the financialization process started impacting commodity price movements prior to the recent turbulent period. However, regarding correlations between commodities as an asset class and traditional financial assets, our results generally show very weak commodity-equity and commodity-bond correlations prior to the Lehman Brothers collapse. This proves the relevance of the "style effect"theory to explain the dynamic links between commodities and both stock and bond markets. However, it may not be possible to consider commodities as a fully-fledged "style", as we detect a significant heterogeneity among commodity groups. Our second major finding is that, during the financial crisis, correlations both across commodities and between commodities and equities increased dramatically, with a regime change that coincided perfectly with the demise of Lehman Brothers on September 15, 2008. This reflects the "loss spiral"effects during the period of financial market tensions. However, commodity-bond correlations switched to a strongly negative regime, showing that government bonds were being considered as refuge securities. The third and most important of our findings contributes to the debate by revealing the temporary nature of the financial crisis effect. Correlations both across commodities and between commodities and traditional assets reverted to their pre-crisis level by April 2013, thus confirming that financial-based factors impact 
commodity price movements.

In the next section, we outline the econometric methodology used in the empirical analysis. Section 3 presents detailed descriptive statistics of the dataset. Section 4 discusses empirical results of analysis across commodities. Section 5 focuses on correlations between commodities and traditional assets. Section 6 concludes.

\section{Methodology}

In this paper, we adopt the general framework of multivariate GARCH models with dynamic conditional correlations. Introduced by Bollerslev (1990), the conditional correlations model was finely tuned by Engle and Sheppard (2001) to introduce time-varying conditional correlations. Formally, the general framework of multivariate GARCH models with dynamic correlations assumes that a stochastic process $r_{t}$ of size $(K \times T)$ is defined by:

$$
r_{t} \mid \mathcal{F}_{t-1} \sim \mathcal{L}\left(0, H_{t}\right)
$$

where $\mathcal{F}_{t-1}$ refers to the information set generated by the observed series $\mathbf{r}_{t}$ up to $t-1$, while $\mathcal{L}$ is a distribution function with zero mean and conditional variance $H_{t}$. The expression of $H_{t}$ is given by:

$$
H_{t}=D_{t} R_{t} D_{t}
$$

where:

$$
D_{t}=\operatorname{diag}\left(h_{1, t}^{1 / 2}, \ldots, h_{K, t}^{1 / 2}\right)
$$

is a diagonal matrix composed of the standard deviation of the $K$ univariate series. This degarching tranformation leads to expressing the standardized residuals as:

$$
\epsilon_{t}=D_{t}^{-1} r_{t}
$$

Then, the expectation of the standardized residuals gives the conditional correlations.

The seminal specification of Engle and Sheppard (2001) proposes a time-varying conditional correlation using an autoregressive formulation for $R_{t}$ such that:

$$
R_{t}=\operatorname{diag}\left\{Q_{t}\right\}^{-1 / 2} Q_{t} \operatorname{diag}\left\{Q_{t}\right\}^{-1 / 2}
$$

The conditional covariance matrix $Q_{t}$ is expressed as a BEKK formulation:

$$
Q_{t}=(1-\alpha-\beta) \bar{Q}+\alpha \epsilon_{i, t-k} \epsilon_{j, t-k}^{\prime}+\beta Q_{t-l}
$$

in which $\bar{Q}$ is the unconditional covariance matrix. Enthusiasm for this class of models resulted in a vast literature, as exhaustively reviewed by Bauwens et al. (2006), Silvennoinen and Teräsvirta (2009), Engle (2009) and Francq and Zakoian (2010).

In this paper, we study the conditional correlations given two constraints arising from our dataset: computationally feasible estimation of the model and the possibility of breaks. A few Markov-switching models have been proposed, like Billio and Caporin (2005), Pelletier (2006) and Haas and Mittnik (2008). The advantage of the Regime Switching for Dynamic Correlations (RSDC) model of Pelletier (2006) lies in offering a Markov-Switching structure for the correlation process by imposing constant correlations within each regime but switch from one regime to another via a Markov chain of order one, at the same time as making it possible to estimate with large datasets. The RSDC model assumes that the conditional correlation matrix has the form:

$$
R_{t}=\sum_{n=1}^{N} \mathbb{1}_{\left\{s_{n}=i\right\}} R_{n}
$$


where $\left\{s_{t}\right\}_{t \in \mathbb{N}}$ is a first order Markov chain with $N$ states and $R_{n}$ a constant correlation matrix. In other words, the correlations evolve between $N$ constant correlations matrices, moving from one to another according to the Markov chain.

The first advantage of the RSDC is economic: unlike autoregressive formulations, which are difficult to understand from an economic point of view, this model has a clear cut economic explanation because each regime is linked to a constant correlation matrix. Secondly, this model can be estimated using an EM algorithm. In fact, the drawback of many dynamic conditional correlations models lies in the fact that estimation of parameters for large datasets can encounter difficulties in handling extensive data. Being able to apply an EM algorithm means that less structured models do not need to be used when handling large datasets.

We use a two-stage estimation for the RSDC where the log- likelihood is written as the sum of the volatility component and the correlation term. For the first step, we perform the estimation of each univariate volatility model using a search procedure across a class of 8 univariate GARCH specifications selected according to the Bayesian information criterion (BIC). Finally, log-likelihood of the volatility component can be written as:

$$
L\left(\theta_{1}\right)=-\frac{1}{2} \sum_{t=1}^{T}\left(K \log (2 \pi)+\log \left(\left|D_{t}\right|^{2}\right)+y_{t}^{\prime} D_{t}^{-2} y_{t}\right)
$$

where $\theta_{1}$ denotes the parameter space for the univariate volatility. The log-likelihood of the correlation term is expressed as follows:

$$
L\left(\hat{\theta_{1}}, \theta_{2}\right)=-\frac{1}{2} \sum_{t=1}^{T}\left(\log \left(\left|R_{t}\right|\right)+\varepsilon_{t}^{\prime} R_{t}^{-1} \varepsilon_{t}-\varepsilon_{t}^{\prime} \varepsilon_{t}\right)
$$

with $\theta_{2}$ the parameter space for the correlation part. Because the latent process is unobserved, the estimation step requires inferring the state of the Markov chain. Let $\xi_{j t}$ be the probability of being in regime $j$ given the information set available at time $t-1$ and $\eta_{j t}$ the density under regime $j$. The probability $\hat{\xi}_{t \mid t}$ of being in a regime at time $t$ given the observations up to $t$ can be computed using Hamilton's filter:

$$
\hat{\xi}_{t \mid t}=\frac{\left(\hat{\xi}_{t \mid t-1} \circ \eta_{t}\right)}{\mathbf{I}^{\prime}\left(\hat{\xi}_{t \mid t-1} \circ \eta_{t}\right)}
$$

with:

$$
\hat{\xi}_{t \mid t+1}=\mathrm{P} \times \hat{\xi}_{t \mid t}
$$

where $P$ is a transition matrix and $\circ$ denotes the element-by-element multiplication. Based on Hamilton (1994), the re-estimation formula allows the elements $p_{i j}$ of the transition matrix $P$ to be updated:

$$
\hat{p}_{i j}=\frac{\sum_{t=2}^{T} \mathbb{P}\left(s_{t}=j, s_{t-1}=i \mid \varepsilon_{T}, \hat{\theta_{2}}\right)}{\sum_{t=2}^{T} \mathbb{P}\left(s_{t}=i \mid \varepsilon_{T}, \hat{\theta_{2}}\right)}
$$

There is no re-estimation formula for directly updating the correlations matrices. In a first step, we update the covariance matrices $Q_{n}$ of the standardized residuals:

$$
\hat{Q}_{n}=\frac{\sum_{t=1}^{T}\left(\hat{\varepsilon}_{t} \hat{\varepsilon}_{t}^{\prime}\right) \mathbb{P}\left(s_{t}=n \mid \varepsilon_{T}, \hat{\theta_{2}}\right)}{\sum_{t=1}^{T} \mathbb{P}\left(s_{t}=n \mid \varepsilon_{T}, \hat{\theta_{2}}\right)}
$$

and then obtain the correlations matrices $\hat{R}_{n}$ by rescaling the covariance $\hat{Q}_{n}$ using the transformation defined in equation 5. As noted by Pelletier (2006), this rescaling produces a value for the log-likelihood obtained by the EM algorithm that does not exactly match the value computed with a Newton-type algorithm, but remains very close to it. Nonetheless, the EM algorithm allows very rapid estimation of high-dimensional systems while maintaining a full structured model where models estimated with numerical methods fail. 


\section{Data}

\subsection{Descriptive statistics}

The data considered in this study consist of 4 commodity indices, namely, the S\&P Goldman Sachs Commodity Index (GSCI), the Dow-Jones UBS (DJ-UBS) Commodity Index (which are the dominant commodity benchmarks for investors) the Rogers International Commodity index (RICI) and the Thomson Reuters/Jefferis CRB Index (CRB), as well as 32 individual commodity futures contract price series. The traditional assets include the S\&P500 as equity asset index and JP Morgan US Government Bond total returns (JPMUS) as bond assets, along with a measure of volatility, the CBOE VIX volatility index, also considered a fear index on financial markets. ${ }^{3}$ Frequency is daily from May 28, 2003, to June 4, 2014, for a total of 2876 observations. Futures contract series can be classified in groups, representing various sectors of the commodity market, as follows:

1. Energy: crude oil (WTI), coal, natural gas.

2. Precious Metals: gold, silver, palladium, platinum.

3. Industrial Metals: aluminum, copper, zinc, tin, lead, nickel.

4. Agriculture: barley, corn, oats, rice, soybeans, soybean oil, wheat, palm oil, sunflowers, cocoa, coffee, sugar, cotton, lumber and orange juice.

- Grains: barley, corn, oats, rice, soybeans, wheat and sunflowers.

- Softs: cocoa, coffee, sugar, cotton, lumber and orange juice.

5. Livestock: live cattle, lean hogs, feeder cattle.

Commodity futures prices used in this study are from Bloomberg, which provides what is known as "generic"futures. Many factors need to be considered in computing "generic"or continuous contracts in order to avoid significant price jumps or drops when concatenating contracts for the same commodity over time. Bloomberg builds "generic"futures series by using a nearest futures contract approach, rolling over from the most active contract or the contract nearest to expiry to the next nearest one. The active contract is typically based on the open interest and volume in the contract. ${ }^{4}$ Our empirical work uses a data set where all variables have been transformed to returns by multiplying the first difference of the logarithm by 100 . In order to approximate the true cost as closely as possible and following Silvennoinen and Thorp (2013) and Hong and Yogo (2011), we take an equally weighted average across returns to generic futures with the available maturity dates in each period and collateralize with the 3-month US Treasury Bill (T-bill), as the risk-free rate, as follows: $y_{i t, F}=\frac{1}{K} \sum_{k=1}^{K} \widetilde{r}_{i, t, \tau_{k}}+r_{f, t}$, where $\widetilde{r}_{i, t, \tau_{k}}$ is the log return to $k$-th futures contract with maturity $\tau_{k}$, and $r_{f}$ is the daily T-bill rate.

Tables 1 and 2 report the summary statistics for different asset classes. As reported in earlier studies, commodity indices and commodity futures other than natural gas and aluminum have higher mean daily returns, between $3 \%$ and $6 \%$, than those of traditional assets, about $2 \%$ and $0.25 \%$ for S\&P 500 and Bonds, respectively. These high commodity returns are coupled with higher volatility relative to both equity and bond assets, confirming the commonly-observed excessive commodity price volatility over recent years attributed to either the boom-and-bust cycle or to excessive speculation by index investors. ${ }^{5}$ Furthermore, all series are leptokurtotic,

\footnotetext{
${ }^{3}$ Data details and sources are given in the Dataset Appendix.

${ }^{4}$ More details about generic contracts are given in Chantziara and Skiadopoulos (2008).

${ }^{5}$ For more details about the two opposing explanation for excessive commodity price volatility, see Tang and Xiong $(2010,2012)$.
} 
Table 1: Descriptive statistics: commodity futures returns.

\begin{tabular}{|c|c|c|c|c|c|c|c|c|c|}
\hline wti & $\begin{array}{l}\text { Mean* } \\
0.0438\end{array}$ & $\begin{array}{c}\text { Min } \\
-8.9974\end{array}$ & $\begin{array}{c}\operatorname{Max} \\
9.8897\end{array}$ & $\begin{array}{c}\text { Var. } \\
3.0802\end{array}$ & $\begin{array}{l}\text { S. dev. } \\
1.7550\end{array}$ & $\begin{array}{c}\text { Med. } \\
0.0610\end{array}$ & $\begin{array}{c}\text { Kurtosis } \\
6.4176\end{array}$ & $\begin{array}{c}\text { Skewness } \\
-0.1863\end{array}$ & $\begin{array}{c}\text { Engle LM test** } \\
10.6053 \\
(5.9791 e-02)\end{array}$ \\
\hline heating oil & 0.0469 & -8.6200 & 8.5821 & 2.7989 & 1.6730 & 0.0090 & 5.2767 & -0.0761 & $\begin{array}{c}9.8504 \\
(7.9586 e-02)\end{array}$ \\
\hline natural gas & -0.0148 & -10.5418 & 8.3090 & 3.3323 & 1.8255 & 0.0148 & 4.6865 & 0.0976 & $\begin{array}{c}22.7141 \\
(3.8280 e-04)\end{array}$ \\
\hline coal & 0.0209 & -9.8928 & 10.3161 & 1.7355 & 1.3174 & -0.0209 & 13.2462 & -0.3336 & $\begin{array}{c}35.1850 \\
(1.3820 e-06)\end{array}$ \\
\hline gold & 0.0423 & -9.9038 & 7.8360 & 1.4245 & 1.1935 & 0.0043 & 8.1521 & -0.5370 & $\begin{array}{c}3.1449 \\
(6.7766 e-01)\end{array}$ \\
\hline silver & 0.0413 & -17.7329 & 12.6415 & 3.9884 & 1.9971 & 0.0647 & 9.1641 & -0.7097 & $\begin{array}{c}2.5285 \\
(7.7220 e-01)\end{array}$ \\
\hline platinum & 0.0301 & -7.1475 & 11.4117 & 1.3411 & 1.1581 & 0.0210 & 10.1054 & 0.0579 & $\begin{array}{c}9.6109 \\
(8.7043 e-02)\end{array}$ \\
\hline palladium & 0.0500 & -13.0528 & 9.8420 & 4.1915 & 2.0473 & 0.0067 & 6.6506 & -0.5696 & $\begin{array}{c}11.7640 \\
(3.8168 e-02)\end{array}$ \\
\hline aluminum & 0.0100 & -7.7585 & 5.6434 & 1.8475 & 1.3592 & -0.0039 & 5.2381 & -0.3544 & $\begin{array}{c}6.6848 \\
(2.456 e-01)\end{array}$ \\
\hline copper & 0.0474 & -10.1199 & 11.5452 & 3.3368 & 1.8267 & -0.0288 & 6.7288 & -0.1615 & $\begin{array}{l}10.4875 \\
(6.2545 e-02)\end{array}$ \\
\hline nickel & 0.0280 & -15.6456 & 12.8105 & 5.5945 & 2.3653 & -0.0279 & 6.1572 & -0.1705 & $\begin{array}{c}3.5365 \\
(6.1787 e-01)\end{array}$ \\
\hline lead & 0.0520 & -12.8007 & 12.3169 & 4.7691 & 2.1838 & 0.0189 & 6.0628 & -0.2894 & $\begin{array}{c}4.4848 \\
(4.8191 e-01)\end{array}$ \\
\hline $\operatorname{tin}$ & 0.0547 & -11.0386 & 13.7926 & 3.6308 & 1.9055 & 0.0033 & 7.9563 & -0.2254 & $\begin{array}{c}5.7381 \\
(3.3254 e-01)\end{array}$ \\
\hline zinc & 0.0326 & -10.2372 & 8.3663 & 3.9190 & 1.9796 & -0.0092 & 5.2176 & -0.2584 & $\begin{array}{c}5.0592 \\
(4.0870 e-01)\end{array}$ \\
\hline corn & 0.0224 & -7.3758 & 8.7767 & 2.1265 & 1.4583 & -0.0200 & 5.9026 & -0.0074 & $\begin{array}{c}1.6067 \\
(9.0044 e-01)\end{array}$ \\
\hline soybeans & 0.0274 & -7.1534 & 6.6567 & 2.3152 & 1.5216 & 0.0345 & 5.5978 & -0.3652 & $\begin{array}{c}1.6498 \\
(8.9516 e-01)\end{array}$ \\
\hline soybean oil & 0.0198 & -7.0416 & 6.5350 & 2.0287 & 1.4243 & -0.0165 & 5.3922 & -0.0027 & $\begin{array}{c}1.8563 \\
(8.6865 e-01)\end{array}$ \\
\hline wheat & 0.0243 & -8.2315 & 7.2575 & 2.4635 & 1.5696 & -0.0231 & 5.5793 & -0.0184 & $\begin{array}{c}6.8854 \\
(2.2930 e-01)\end{array}$ \\
\hline coffee & 0.0324 & -10.7111 & 10.9987 & 3.1794 & 1.7831 & -0.0099 & 5.5894 & 0.1429 & $\begin{array}{c}6.1642 \\
(2.9057 e-01)\end{array}$ \\
\hline cotton & 0.0093 & -7.8303 & 6.2534 & 1.9679 & 1.4028 & 0.0230 & 5.2593 & -0.1629 & $\begin{array}{c}6.4381 \\
(2.6589 e-01)\end{array}$ \\
\hline orange juice & 0.0201 & -11.3623 & 10.2091 & 2.7022 & 1.6438 & 0.0295 & 7.1633 & -0.2721 & $\begin{array}{c}9.2091 \\
(1.0101 e-01)\end{array}$ \\
\hline barley & 0.0112 & -54.5683 & 53.4137 & 5.5580 & 2.3575 & -0.0112 & 212.7716 & 0.4454 & $\begin{array}{c}11.4333 \\
(4.3435 e-02)\end{array}$ \\
\hline oats & 0.0289 & -11.1912 & 11.8538 & 2.6695 & 1.6339 & 0.0096 & 7.6775 & -0.0651 & $\begin{array}{c}18.6134 \\
(2.2682 e-03)\end{array}$ \\
\hline rice & 0.0205 & -6.7346 & 6.3782 & 1.6521 & 1.2853 & -0.0205 & 4.8653 & 0.0047 & $\begin{array}{c}4.9306 \\
(4.2441 e-01)\end{array}$ \\
\hline palm oil & 0.0202 & -10.0779 & 7.4185 & 1.7139 & 1.3092 & -0.0198 & 8.6608 & -0.4479 & $\begin{array}{c}2.3458 \\
(7.9952 e-01)\end{array}$ \\
\hline cocoa & 0.0235 & -8.8601 & 7.5449 & 2.6824 & 1.6378 & -0.0067 & 5.8077 & -0.1880 & $\begin{array}{c}3.7737 \\
(5.8244 e-01)\end{array}$ \\
\hline sugar & 0.0297 & -10.4868 & 6.7202 & 2.3486 & 1.5325 & 0.0116 & 7.4521 & -0.6231 & $\begin{array}{c}12.5627 \\
(2.7840 e-02)\end{array}$ \\
\hline lumber & 0.0079 & -5.1275 & 7.0852 & 1.3683 & 1.1697 & -0.0079 & 5.4558 & 0.4772 & $\begin{array}{c}17.9320 \\
(3.0329 e-03)\end{array}$ \\
\hline sunflowers & 0.0321 & -8.2065 & 12.6384 & 0.7954 & 0.8919 & -0.0265 & 23.0523 & 0.2749 & $\begin{array}{c}111.0000 \\
(0.0000 e+00)\end{array}$ \\
\hline lean hogs & 0.0180 & -4.9718 & 5.9656 & 0.8693 & 0.9324 & 0.0344 & 5.6446 & -0.2404 & $\begin{array}{c}1.7156 \\
(8.8693 e-01)\end{array}$ \\
\hline live cattle & 0.0233 & -4.0081 & 3.2186 & 0.4796 & 0.6925 & 0.0150 & 5.7203 & -0.3185 & $\begin{array}{c}6.1628 \\
(2.9070 e-01)\end{array}$ \\
\hline feeder cattle & 0.0287 & -4.9763 & 3.0858 & 0.4940 & 0.7029 & 0.0076 & 5.8747 & -0.3607 & $\begin{array}{c}18.9979 \\
(1.9238 e-03)\end{array}$ \\
\hline Engle DCC test** & $\begin{array}{l}(118.7318) \\
(0.0000 e+00)\end{array}$ & & & & & & & & \\
\hline
\end{tabular}

This table reports summary statistics for the 32 daily collateralized commodity futures returns from May 28 , 2003 to June 4, 2014. We take futures returns (changes in log prices multiplied by 100) and collateralize them with the daily 3-month US Treasury Bill (T-bill) secondary market rate. Details about commodity futures contracts and sources are provided in Appendix A.

with some high values for barley and sunflowers. One explanation for the increasing demand for commodities in recent years is return distribution. As commodity returns are usually positively skewed and less volatile than traditional assets, which are usually positively skewed, they entail lower downward risk than traditional assets. When the tail event occurs simultaneously for both commodities and traditional assets, commodities add diversification benefits to the portfolio allocation. Conversely, however, for the considered sample, the distribution of commodity returns is negatively skewed, except for natural gas, barley, soybean oil, sunflowers and lumber, also showing volatility relative to traditional assets, suggesting that the diversification benefits of commodities can vanish. 
Table 2: Descriptive statistics: commodity indices and financial series.

\begin{tabular}{|c|c|c|c|c|c|c|c|c|c|}
\hline VIX & $\begin{array}{l}\text { Mean* } \\
-0.0194\end{array}$ & $\begin{array}{c}\text { Min } \\
-34.8762\end{array}$ & $\begin{array}{c}\text { Max } \\
40.4722\end{array}$ & $\begin{array}{c}\text { Var. } \\
36.9983\end{array}$ & $\begin{array}{l}\text { S. dev. } \\
6.0826\end{array}$ & $\begin{array}{c}\text { Med. } \\
-0.2449\end{array}$ & $\begin{array}{c}\text { Kurtosis } \\
7.6601\end{array}$ & $\begin{array}{c}\text { Skewness } \\
0.6535\end{array}$ & $\begin{array}{c}\text { Engle LM test** } \\
29.0372 \\
(2.2801 e-05)\end{array}$ \\
\hline SP500 & 0.0245 & -9.4665 & 10.8993 & 1.5034 & 1.2261 & 0.0281 & 14.9362 & -0.3456 & $\begin{array}{l}11.0127 \\
(5.1128 e-02)\end{array}$ \\
\hline JPMUS & 0.0149 & -1.9720 & 2.1031 & 0.0925 & 0.3041 & -0.0075 & 5.6525 & -0.0232 & $\begin{array}{c}11.7970 \\
(3.7678 e-02)\end{array}$ \\
\hline DJUBS & 0.0042 & -6.4065 & 5.6433 & 1.2508 & 1.1184 & -0.0042 & 5.6604 & -0.2686 & $\begin{array}{c}3.8549 \\
(5.7049 e-01)\end{array}$ \\
\hline GSCI & 0.0077 & -8.6565 & 7.2070 & 2.2747 & 1.5082 & -0.0077 & 5.9488 & -0.2421 & $\begin{array}{l}7.5208 \\
(870 e-01\end{array}$ \\
\hline RICI & 0.0229 & -7.6446 & 6.2630 & 1.5286 & 1.2364 & 0.0041 & 6.5998 & -0.3501 & $\begin{array}{l}5.9896 \\
30724 e-01)\end{array}$ \\
\hline JFCRB & 0.0131 & -6.8909 & 5.7332 & 1.2985 & 1.1395 & -0.0024 & 6.2877 & -0.3217 & $\begin{array}{c}4.9948 \\
(4.1652 e-01)\end{array}$ \\
\hline GSCIAG & -0.0003 & -7.4749 & 7.1571 & 1.9301 & 1.3893 & 0.0003 & 5.2609 & -0.1334 & $\begin{array}{c}0.9470 \\
(9.6673 e-01)\end{array}$ \\
\hline GSCIIM & 0.0322 & -9.0473 & 7.5567 & 2.6422 & 1.6255 & -0.0317 & 5.3376 & -0.2803 & $\begin{array}{c}9.1893 \\
(1.0175 e-01)\end{array}$ \\
\hline GSCIEN & 0.0055 & -9.6141 & 9.7997 & 3.6001 & 1.8974 & -0.0055 & 5.7241 & -0.1661 & $\begin{array}{c}7.5972 \\
(1.598 e-01)\end{array}$ \\
\hline GSCILIVE & -0.0073 & -4.2411 & 3.2617 & 0.7259 & 0.8520 & 0.0073 & 3.9197 & -0.1843 & $\begin{array}{c}5.2175 \\
(3.8991 e-01)\end{array}$ \\
\hline GSCIPM & 0.0396 & -10.1443 & 8.7219 & 1.7237 & 1.3129 & 0.0009 & 8.0151 & -0.5434 & $\begin{array}{c}2.1419 \\
(8.2919 e-01)\end{array}$ \\
\hline Engle DCC test** & & & & & & & & & \\
\hline
\end{tabular}

In brackets, critical values for the tests. ${ }^{*}$ Mean of the series in returns. ${ }^{* *}$ With 5 lags.

This table reports summary statistics for 4 commodity index and sub-index returns, as well as equity and bond returns (changes in log prices multiplied by 100). Commodity indices are: Goldman Sachs Commodity Index (GSCI), Dow Jones UBS Commodity Index (DJ-UBS), Reuters/Jefferies Commodity Research Bureau Index (RJ/CRB) and Rogers' International Commodity Index (RICI). The sub-indices used in this analysis are those of the GSCI index, namely, GSCI Energy (GSCIEN), GSCI Industrial Metals (GSCIIM), GSCI Agriculture (GSCIAG), GSCI Livestock (GSCILS) and GSCI Precious Metals (GSCIPM). For equity returns we used Standard and Poor's S\&P 500 and for bond returns the JP Morgan US Government Bond total returns (Datastream database). Along with financial variables we also include the CBOE VIX volatility index. Data are obtained from Bloomberg and span the period between May 28, 2003 and June 4, 2014.

A second explanation for the increasing investment in commodities is the weak, even negative, correlation between commodities and traditional asset returns, which encourages investors to use commodities to reduce portfolio risk. As reported in Tables 1 and 2, Engle's LM1 tests and Engle's DCC tests, all with five lags, confirm the absence of serial correlation and reject the hypothesis of constant correlations. Table 3 then summarizes information about unconditional correlations, both inter- and intra- group, and with the SP500 and US bonds throughout the period, as well as for the pre- and post-global financial crisis periods.

The unconditional correlations throughout the period (Table 3a) show that energy, Precious Metals, industrial Metals and oils have a significant positive correlation, while Agriculture and Softs seem to show intra-heterogeneity, with a relatively weak correlation coefficient. The intergroup correlations point to a certain independence in how sectors evolve. The highest correlation is between Precious and Industrial Metals groups. Commodity groups and indices have positive and relatively high correlations with the S\&P 500 and negative correlations with US bonds. However, tables $3 \mathrm{~b}$ and $3 \mathrm{c}$ show a sharp contrast between correlations before and after the financial crisis, suggesting a significant change in the correlation process. In the pre-crisis period, correlations between commodity futures and indices returns and the S\&P 500 are very low and even negative for energy and oil groups and the GSCI index, despite the fact that, as pointed out by Tang and Xiong $(2010,2012)$, the financialization process started from 2004. In contrast, during the post-crisis period, correlations with equity indices increase significantly. A strong increase in inter-group average correlations is also observed, confirming earlier results in the literature suggesting increased correlations in bear markets (see Ang and Chen (2002), Longin and Solnik (2001), and Campbell et al. (2002)). Cross-group correlations also increase between periods, but only slightly. These descriptive statistics confirm our choice of non-linear specification to analyze the link between commodities and traditional asset classes.

Estimation with the RSDC involves first extracting the univariate volatility of each series. Following Cappiello et al. (2006), we tested seven GARCH models (all at first order): GARCH, 
Table 3: Average correlations across commodity groups and with financial assets.

\begin{tabular}{lcccccccc}
\hline \hline & Energy & Precious Met & Industrial Met & Grains & Softs & Live & DJ-UBS & GSCI \\
Intra groups & & & & & & & & \\
Ave. & 0.4233 & 0.6079 & 0.5847 & 0.2463 & 0.1302 & 0.4597 & & \\
Min. & 0.2990 & 0.5124 & 0.4712 & 0.0142 & 0.0464 & 0.2486 & & \\
Max. & 0.9235 & 0.7557 & 0.7476 & 0.7910 & 0.2682 & 0.7620 & & \\
& & & & & & & & \\
Inter groups & & & & & & & & \\
Energy & & 0.24 & 0.24 & 0.18 & 0.16 & 0.14 & 0.60 & 0.66 \\
Precious Met & & & 0.35 & 0.18 & 0.17 & 0.10 & 0.49 & 0.37 \\
Industrial Met & & & & 0.16 & 0.17 & 0.12 & 0.52 & 0.41 \\
Grains & & & & & 0.14 & 0.09 & 0.36 & 0.27 \\
Softs & & & & & & 0.10 & 0.28 & 0.23 \\
Live & & & & & & & 0.23 & 0.20 \\
DJ-UBS & & & & & & & & 0.91 \\
With indices & & & & & & & & \\
SP500 & 0.2274 & 0.1469 & 0.2524 & 0.1184 & 0.1521 & 0.1327 & 0.3100 & 0.3186 \\
JPMUS & -0.1140 & -0.0315 & -0.1555 & -0.0779 & -0.0813 & -0.0887 & -0.1830 & -0.1976 \\
\hline \hline
\end{tabular}

(a) $06 / 2003-03 / 2014$

\begin{tabular}{|c|c|c|c|c|c|c|c|c|}
\hline & Energy & Precious Met & Industrial Met & Grains & Softs & Live & DJ-UBS & GSCI \\
\hline \multicolumn{9}{|l|}{ Intra groups } \\
\hline$\overline{\text { Ave. }}$ & 0.4263 & 0.5313 & 0.5058 & 0.2162 & 0.0975 & 0.4208 & & \\
\hline Min. & 0.1970 & 0.4330 & 0.3393 & -0.0055 & 0.0019 & 0.2026 & & \\
\hline Max. & 0.9237 & 0.6965 & 0.7216 & 0.7886 & 0.2321 & 0.7523 & & \\
\hline \multicolumn{9}{|l|}{ Inter groups } \\
\hline$\overline{\text { Energy }}$ & & 0.22 & 0.14 & 0.13 & 0.12 & 0.07 & 0.59 & 0.66 \\
\hline Precious Met & & & 0.30 & 0.16 & 0.15 & 0.07 & 0.44 & 0.31 \\
\hline Industrial Met & & & & 0.08 & 0.10 & 0.02 & 0.41 & 0.26 \\
\hline Grains & & & & & 0.11 & 0.03 & 0.28 & 0.18 \\
\hline Softs & & & & & & 0.05 & 0.20 & 0.13 \\
\hline Live & & & & & & & 0.10 & 0.07 \\
\hline DJ-UBS & & & & & & & & 0.90 \\
\hline \multicolumn{9}{|l|}{ With indices } \\
\hline$\overline{\text { SP500 }}$ & -0.0192 & 0.0288 & 0.0996 & 0.0024 & 0.0421 & -0.0168 & 0.0255 & -0.0309 \\
\hline JPMUS & 0.0226 & 0.0353 & -0.0289 & -0.0268 & -0.0178 & -0.0301 & -0.0179 & 0.0038 \\
\hline \multicolumn{9}{|c|}{ (b) Pre-15/09/2008 } \\
\hline & Energy & Precious Met & Industrial Met & Grains & Softs & Live & DJ-UBS & GSCI \\
\hline \multicolumn{9}{|l|}{ Intra groups } \\
\hline$\overline{\text { Ave. }}$ & 0.4279 & 0.6594 & 0.6490 & 0.2748 & 0.1529 & 0.4986 & & \\
\hline Min. & 0.2134 & 0.5004 & 0.5378 & 0.0211 & 0.0475 & 0.2959 & & \\
\hline Max. & 0.9310 & 0.7945 & 0.7713 & 0.7950 & 0.3130 & 0.7719 & & \\
\hline \multicolumn{9}{|l|}{ Inter groups } \\
\hline$\overline{\text { Energy }}$ & & 0.26 & 0.32 & 0.22 & 0.19 & 0.20 & 0.62 & 0.67 \\
\hline Precious Met & & & 0.38 & 0.19 & 0.18 & 0.13 & 0.53 & 0.42 \\
\hline Industrial Met & & & & 0.22 & 0.22 & 0.21 & 0.62 & 0.53 \\
\hline Grains & & & & & 0.16 & 0.14 & 0.42 & 0.35 \\
\hline Softs & & & & & & 0.14 & 0.34 & 0.30 \\
\hline Live & & & & & & & 0.34 & 0.32 \\
\hline DJ-UBS & & & & & & & & 0.91 \\
\hline \multicolumn{9}{|l|}{ With indices } \\
\hline SP500 & 0.3632 & 0.2049 & 0.3403 & 0.1805 & 0.2088 & 0.2229 & 0.4604 & 0.5093 \\
\hline JPMUS & -0.2300 & -0.0814 & -0.2618 & -0.1195 & -0.1322 & -0.1406 & -0.3162 & -0.3665 \\
\hline
\end{tabular}

(c) Post-15/09/2008

This table provides the average unconditional correlations within and between commodity groups, and those of commodity groups and commodity indices with the S\&P 500 and US bonds. Panel (a) shows correlations using data for all sample periods from 06/03/2003 to 06/04/2014, panels (b) and (c) show correlation results using respectively pre- and post-crisis periods.

EGARCH, FIGARCH, ZARCH, GJR-GARCH, AGARCH and NAGARCH, adding to them the MS-GARCH (Haas et al., 2004). This pool of models gave us the option of choosing between a simple GARCH model and models including asymmetry, threshold effects or long memory. Model 
selection was performed using a Bayesian information criterion. ${ }^{6}$

\section{Co-movements across commodities}

Investable commodity indices grew rapidly in recent years because they offer wide exposure to different commodity futures in different sectors in commodity markets, allowing index investors to reduce the risk of their overall investment portfolios, whilst avoiding problems linked to the management of the physical goods. In order to replicate the commodity index, institutional investors, or swap dealers where institutional investors outsource the management of their futures trading, must have a long position on the underlying commodity futures. This increasing trading in and out of commodity futures is called financialization of commodities.

According to the "style investment"theory of Barberis and Shleifer (2003) and Barberis et al. (2005), developed in the context of stock markets and adapted by Basak and Pavlova (2013) to commodities, commodity index investment leads to an increase in correlations among seemingly unrelated commodities which are part of a commodity index. This increases homogeneity between different indexed commodities, leading them to be accepted as a distinct asset class or "style", like equity and fixed interest asset classes. Amongst other qualitative criteria for recognizing an asset class satisfied by commodities, namely sufficient market capitalization, availability of pricing and investability, commodity futures forming an asset class should exhibit a sufficiently low correlation with other asset classes. This will be covered in the next section.

However, a financial crisis can amplify financialization effects. When the market collapses, investors, particularly if leveraged, are drawn into a "loss spiral" (Brunnermeier and Pedersen (2009)), selling assets to raise liquidity and thereby causing falls in unrelated asset returns ${ }^{7}$. This commonly produces another unrelated-to-fundamentals effect that sharply increases correlations both across commodities as a distinct asset class and between commodities and other classes. Relatedly, Singleton (2012) documents the significant contribution of flows from institutional investors to the 2008 boom/bust in oil prices.

We first examine the estimation results on correlations among the full range of commodities and then further the analysis by investigating correlations between Non-Energy commodities and WTI. By allowing for more than two regimes, the RSDC model ensures that the dynamics of the correlation process related to the different commodity co-movement phases are taken into account, before, during and after both financialization and financial crisis.

\subsection{Co-movements across the full range of commodities}

As pointed out by earlier studies, estimating multivariate GARCH models with time-varying conditional correlations is an extremely difficult task, and even more so when the number of commodities increases. The notable advantage of estimating the RSDC model by an EM algorithm lies in the fact that a large number of conditional correlations can be estimated without the specification constraints that are usually entailed when dealing with a large number of series. Moreover, unlike autoregressive formulations which deliver information that is not easily interpretable from an economic point of view, the RSDC model offers a clear-cut economic explanation, given that each regime is linked to a constant correlation matrix which can cross-referenced, for instance to bull or bear market periods. This enables us to shed light on more general commodity market behavior during recent years through applying the theories mentioned above, while

\footnotetext{
${ }^{6}$ Selected models and estimated parameters for the 32 series of commodities, commodity(sub-) indices and traditional assets are reported in the supplementary Apendix (Tables 1 and 2 page 6). Figures 5 and 6 , in the supplementary Appendix, show the estimated volatilities for commodities and the indices, respectively.

${ }^{7}$ Closely related to the "loss spiral" theory of Brunnermeier and Pedersen (2009), Kyle and Xiong (2001) propose a model explaining that in times of financial crisis, financial intermediaries experience wealth effects, reducing their risk-bearing capacity and pushing them to sell all types of assets held in their portfolios.
} 
making allowance for the regime changes detected by the model. To this end and as in Tang and Xiong $(2010,2012)$, we distinguish between In-index and Off-index commodities. This distinction is based on the fact that the latter are not bought and sold by commodity index providers to offset their net position and should not therefore be subject to the financialization process and to the "style"effect. A weaker correlation can therefore be expected between Off-index commodities than between indexed commodities. Our Off-index sample contains coal, barley, palm oil and sunflowers. ${ }^{8}$ Furthermore, we distinguish between commodity groups in order to detect any dynamic correlation divergence into commodity classes and then, at a more disaggregated level, we analyze the bivariate dynamic commodity return correlations.

Figure 1: Overall commodity conditional correlations

Smoothed probability

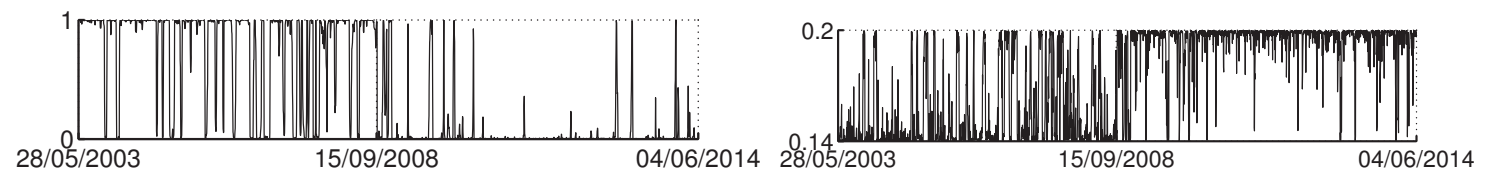

(a) Total commodities

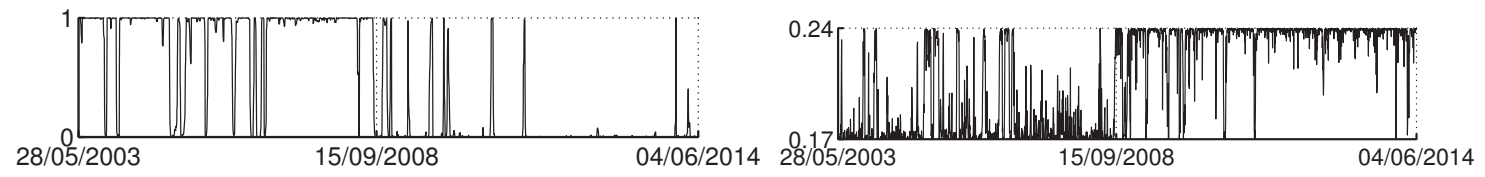

(b) In-index commodities

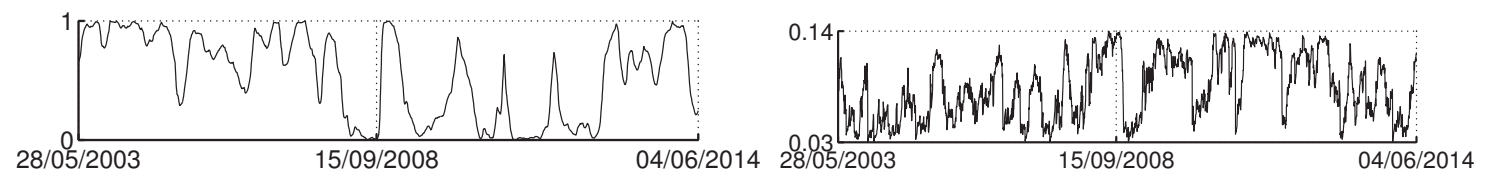

(c) Off-index commodities

Note: this figure provides the estimated smoothed probability (left) and equally average correlation pairs of commodity futures daily returns (right), for the period between May 28, 2003 and June 4, 2014. Panel (a) contains results for the all commodity sample and the bottom two panels ((b) and (c)) reports results for respectively In- and Off-index commodity futures returns. The timeline of the figure in panels (a) and (b) indicates a correlation regime change on September 15, 2008, corresponding exactly to the Lehman Brothers demise. Regime One refers to the weaker correlation regime. Panel (c) indicates that correlations across Offindex commodity futures returns vary without regime change.

Figure 1 reports probabilities and the dynamics of the equally average correlation pairs of overall commodity futures returns. It is easy to see that the financial crisis period involves a new correlation regime between different commodity futures returns, with a regime change that coincides exactly with Lehman Brothers' collapse on September 15, 2008. Furthermore, the transition matrix ${ }^{9}$ indicates that each regime is highly persistent with the probability of staying in a regime being higher than $0.99 .^{10}$ The second regime, coinciding with the financial crisis and the Lehman default, corresponds to an increase in magnitude of all correlations relative to those in the low correlation regime (Figure 1a). The equally weighted average of returns correlations of all commodity pairs increases from about 0.14 to 0.20 , suggesting that commodity markets are

\footnotetext{
${ }^{8}$ We use a different definition of In- and Off-index commodities from that of Tang and Xiong (2010, 2012). We consider commodities not only in the GSCI and the DJ-UBS but also in RICI and JF/RBC as "In-index", "Off-indexed" otherwise. We think that although the GSCI and DJ-UBS are the most important indices, the two others are not negligible in terms of trading volume (US dollar 55bn, 23bn, $1 \mathrm{bn}$ and 3.5bn, respectively). That being said, we do estimate correlations of Off-index commodities following the definition of Tang and Xiong (2010, 2012) and, as expected, we do not find a significant difference from those of In-index commodities. Results are not reported in the paper but available upon request.

${ }^{9}$ Results are not reported but are available upon request.

${ }^{10}$ It could be argued that, as in Tang and Xiong (2010, 2012), the financialization process that began in 2004 may have led to a regime change in the dynamic correlation across commodities. Hence, as a robustness check, we estimated our model with three and even four regimes. Results clearly indicate the absence of an additional significant regime, and are available upon request.
} 
driven more by broader trends than by fundamental factors specific to each market. This result confirms the "loss spiral" argument that correlations between unrelated assets increase in periods of extreme conditions. However, this argument suggests that dynamic correlations should have transitioned back to the low correlation regime as the financial crisis wound down in May 2009 and the recession in the US officially ended in June 2009. Our sample length covers a long enough period after the crisis to enable us to detect any return to the lower correlation regime (regime One). It is worth noting that regime One does seem to show up again on some occasions: very briefly in early 2010 and, in late 2012, and more frequently in 2013.

However, this result does not allow us to conclude firmly on the temporary nature of the financial crisis effect. Rather, it shows that the effect lasted longer than expected after the immediate crisis abated in 2009. It is true that the high financial asset volatility concomitant with the financial crisis, as measured by the VIX (see Figure 2 in the supplementary Appendix page 3), had ended by mid-2009, but two significant spikes emerge in May-October 2010 and August 2011-April 2012, which could have prolonged the initial effect of the 2007-2008 financial crisis. However, as the higher correlation regime extends beyond April 2012, the financial crisis cannot fully account for this regime. An alternative explanation might be that investors' risk preferences were lastingly impacted by extreme events, outlasting the actual estimated shift in correlation.

On the other hand, Figure 1a shows that before the significant rise in the higher correlation regime (regime Two), dynamic correlations seem to initiate a slight increasing trend, confirming Tang and Xiong $(2010,2012)$ 's view and the "style"investment argument that the financialization process started impacting commodity correlations before the financial crisis. Moreover, as shown in Figure 1c, despite the absence of an identified regime change, Off-index commodity correlations are subject to a ceiling varying between 0.03 and 0.14 , with more steady increases after the Lehman Brothers default. These results indicate a certain disconnection between Off-index commodities, providing additional evidence for the financialization effect in indexed commodities, and confirm the findings of Basak and Pavlova (2013) and Tang and Xiong (2010,2012) that financialization affects not only In-index commodities but also, to a lesser extent, Off-index commodities. However, our estimated average correlations of In- and Off-index commodities differ in magnitude from those of Tang and Xiong $(2010,2012)$. This difference may be due to different definitions of Off-index commodities and to different estimation methodologies.

However, the dynamic correlations of the overall sample may mask large variations among commodity groups. By analyzing specific groups, we identified three main types of switching dynamic (Figure 11 in Appendix C). The special feature of the first group, composed of Grains, Softs, Livestock and Precious Metals (Figures 11c, 11d, 11e and 11f, respectively), is that correlations vary, without identified regime switches, between 0.16 and $0.26,0.05$ and $0.18,0.38$ and 0.5, and 0.51 and 0.68, respectively. For the second group, composed of Energy commodities, we observe a different dynamic correlation path. The higher correlation regime (regime Two) starts well before the 2008 financial crisis, and regime One returns and firmly establishes it self at the end of fall 2012 (Figure 11a); correlations then decline to even below their pre-crisis levels. This proves the temporary nature of the financial crisis effect on this group and would tend to reinforce the idea that the "loss spiral" mechanism triggered by the financial crisis was simply revealing the financialization and "style" investment process effect on the commodity returns correlation dynamics. By contrast, however, our findings on correlations across the third group, Industrial Metals, deserve particular attention: this group undergoes a regime change slightly after the Lehman Brothers demise on September 15, 2008 (Figure 11b), and the weaker correlation regime (regime One) shows up again at the end of the sample. Moreover, it is worth noting the remarkable similarity between the dynamic correlations of this group and those of the overall sample, suggesting that the dynamic switching of the former drives that of the latter. 


\subsection{Co-movements between Non-Energy commodities and WTI}

A complementary strategy to study dynamic correlations across commodities is to evaluate correlations of the constituent commodities with their index, as done in Barberis et al. (2005) for stock markets. Moreover, as by construction the index is correlated with its constituents, we use WTI as a proxy for commodity indices since it is the most heavily weighted commodity across the four commodity indices used in this study. This solution is also used by Tang and Xiong (2010, 2012). We first focus on correlations between the overall Non-Energy commodity sample and WTI; then we compare different commodity Non-Energy groups' correlation with WTI; finally, we separately treat the correlations of individual commodities with WTI to obtain greater detail. For these estimations, we construct three equally-weighted indices of Total, In-index and Off-index Non-Energy commodities. This allows us to estimate probabilities of regime change for dynamic correlations only between Non-Energy commodities and WTI, thereby eliminating those across Non-Energy commodities themselves.

Figure 2: Total Non-Energy commodity-WTI conditional correlations

Smoothed probability

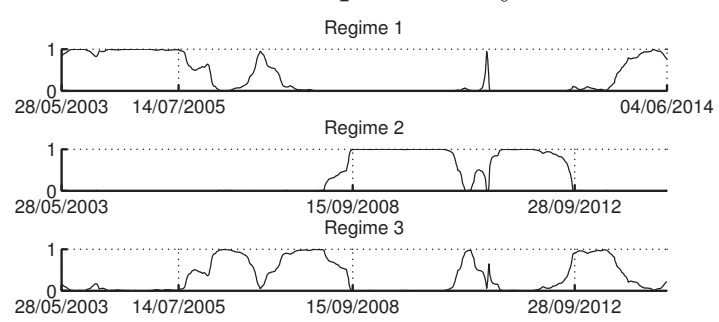

(a) Total Non-Energy commodity-WTI

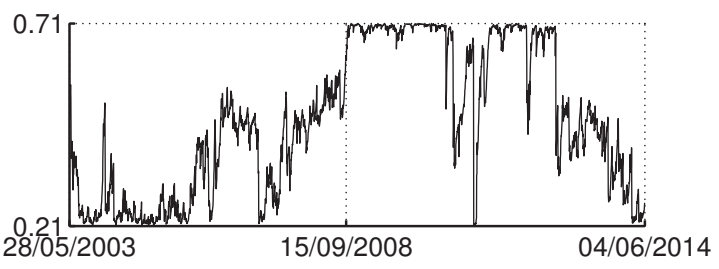

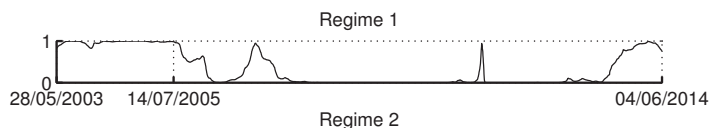
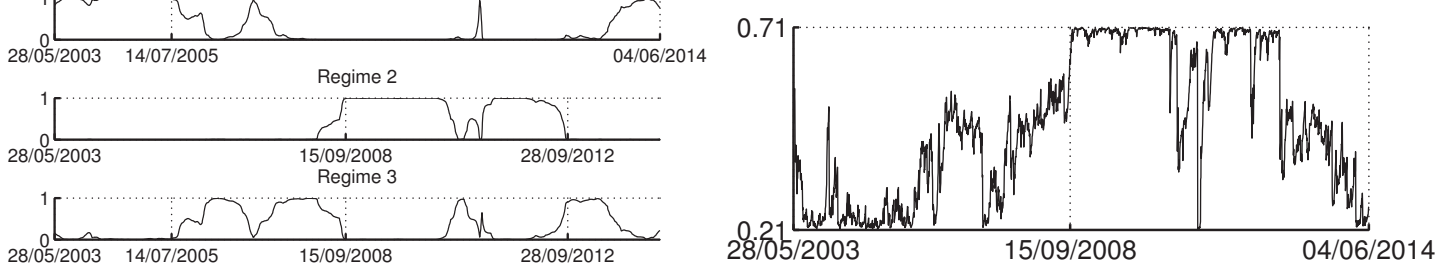

(b) In-index Non-Energy/WTI
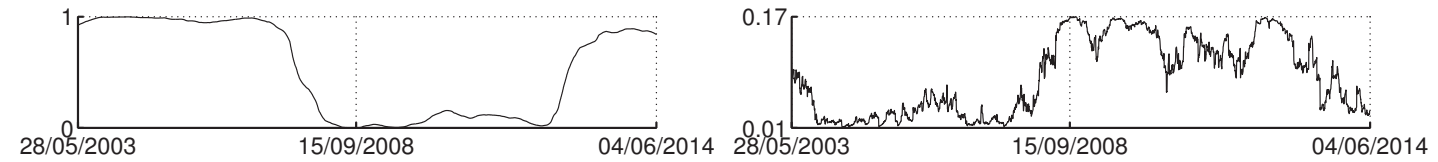

(c) Off-index Non-Energy/WTI

Note: this figure plots the estimated smoothed probability (left) and dynamic correlation of the equally-weighted indices of Non-Energy commodity futures returns with WTI (right), using daily data between May 28, 2003 and June 4, 2014. Panel (a) contains results from the equally-weighted index constructed from the total non-energy commodity futures returns. Panels (b) and (c) contain results from the equally-weighted indices constructed from In- and Off-index Non-Energy commodity futures returns, respectively. Results indicate three dynamic correlation regimes for Total and In-index commodities. While the weaker correlation regime (regime One) corresponds to the period preceding the financialization process, the higher correlation regime (regime Two) corresponds to the financial crisis period. Regime Three, the intermediate correlation regime, reflects commodity financialization. Only two regimes are identified for Off-index Non-Energy commodities: regime One and regime Two correspond respectively to the weaker and higher regimes.

Smoothed probabilities and the dynamic Non-Energy commodity index-WTI correlations in Figure 2 reveal several important results. First, the RSDC model detects three significant regimes corresponding to lower, intermediate and higher correlations. During the intermediate regime (regime Three), correlations followed a new upward trend, gradually going from about 0.20 in July 2005 to about 0.60 just before the Lehman Brothers collapse in September 2008. This may reflect the financialization effect and reinforces the "style" effect theory, confirming empirical findings by Tang and Xiong $(2010,2012)$ that the average correlation of Non-Energy commodity 
Figure 3: Non-Energy commodity groups-WTI conditional correlations

Smoothed probability

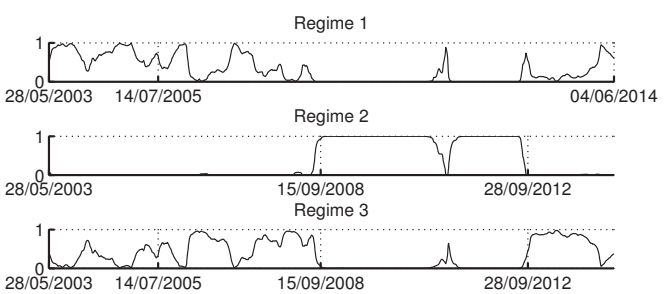

Estimated correlations

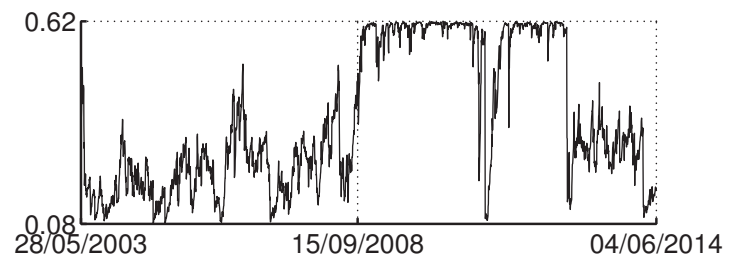

(a) Industrial Metals/WTI
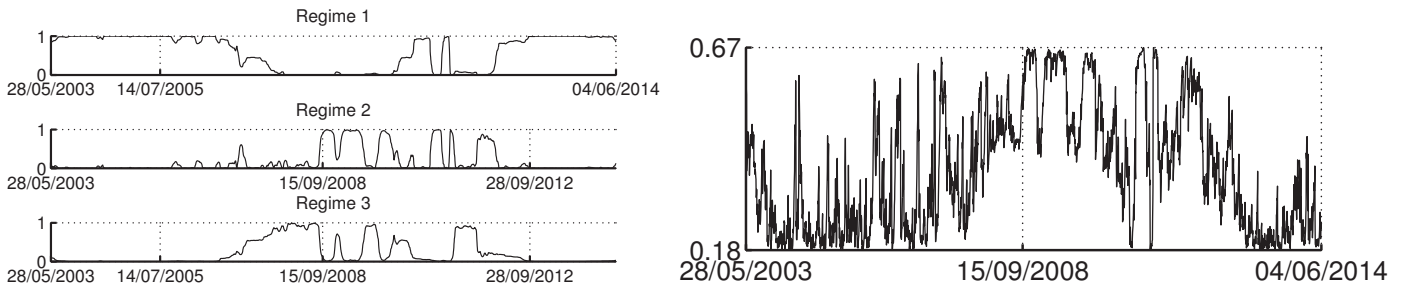

(b) Agriculture/WTI
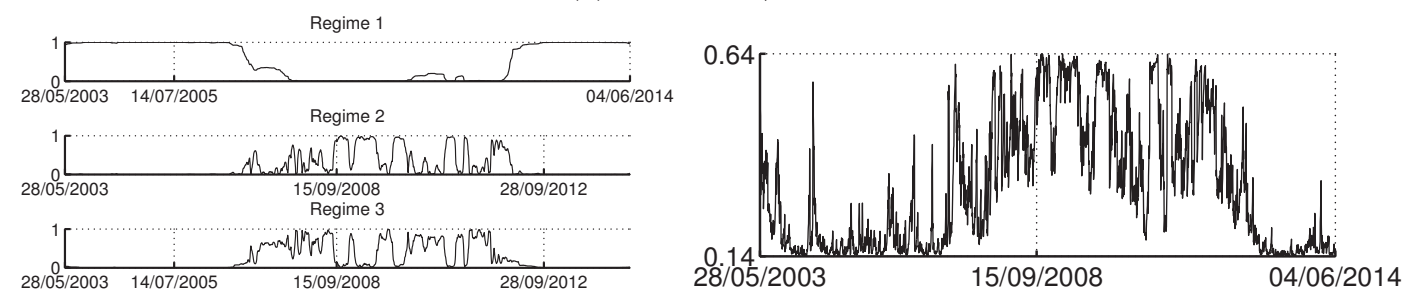

(c) Grains/WTI
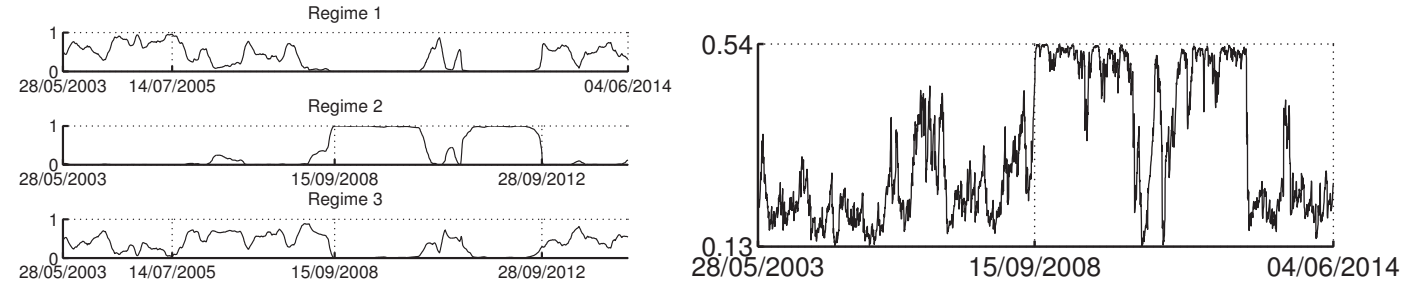

(d) Softs/WTI

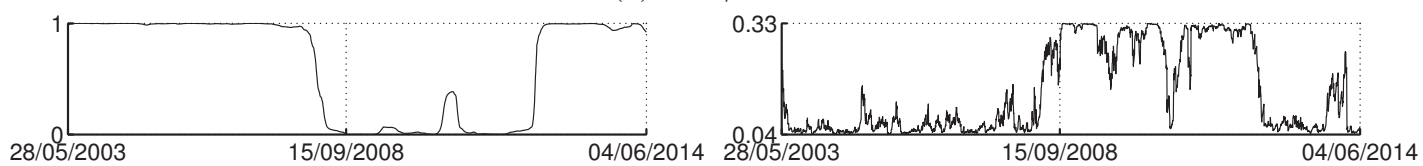

(e) Livestock/WTI

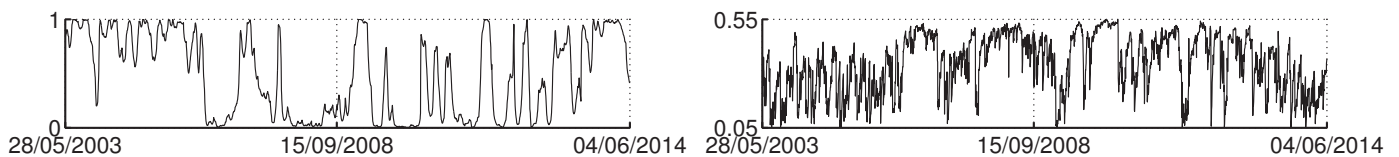

(f) Precious Metals/WTI

Note: this figure plots the estimated smoothed probability (left) and dynamic correlation of the equally-weighted indices returns, constructed from Non-Energy commodity futures groups (as defined in Section 3), with WTI (right), using daily data between May 28, 2003 and June 4, 2014. For instance, Panel (a) contain results from the equally-weighted index constructed from Industrial Metals futures returns. Results indicate three dynamic correlation regimes for Industrial Metals, Agriculture, Grains and Softs groups. The weaker correlation regime (regime One) corresponds to the period preceding the financialization process, the higher correlation regime (regime Two) corresponds to the financial crisis period. Regime Three, the intermediate correlation regime, reflects commodity financialization. Only two regimes, lower (regime One) and higher (regime Two) regimes, are identified for Livestock and Precious Metals.

futures returns with WTI started increasing well before the financial crisis. Second, correlation is indeed found to have increased significantly on September 15, 2008, to about 0.70, remaining high until September 2012. Importantly, therefore, our results for the first time reveal the temporary 
nature of the financial crisis effect.

This is compelling evidence in support of the "loss spiral" argument and the market-of-one notion, implying a reversion to the lower pre-crisis correlation regime. As explained above, since the financial crisis officially ended in June 2009, the brief turbulent periods that followed between 2010 and mid-2012 may appear to have prolonged the financial crisis regime. A third important finding is that, correlations reverted to the pre-crisis level in a gradual manner: first the intermediate regime (regime Three) started to show up again in September 2012, before giving way to the lower correlation regime (regime One). Fourth, we find that Off-index Non-Energy commodity-WTI correlations rose to 0.17 during the financial crisis and reverted to pre-crisis levels in September 2012 (Figure 2c). Although correlations started to increase a little before the Lehman Brothers demise, our model did not separate out this relatively small upward trend as a fully-fledged regime. ${ }^{11}$ This finding further confirms the above-discussed theories and is consistent with Tang and Xiong (2010, 2012) and Basak and Pavlova (2013), who found that financialization and, by implication, financial crisis effects are more pronounced on In-index than on Off-index commodity futures returns.

Other interesting findings are identified when analyzing the correlations of different NonEnergy commodity groups with WTI (Figure 3).On the one hand, dynamic correlations between the different commodity groups (except for Precious Metals and Livestock) and WTI are characterized by three separate regimes. This is very similar to results from Total and In-index Non-Energy commodities. On the other hand, Livestock group-WTI correlations follow a different path: only two regimes are detected, with a low correlation regime until September 15, 2008, giving way to the high financial crisis regime, and appeared again at the end of September 2012. Precious Metals too highlights the heterogeneity in Non-Energy commodity-WTI correlations. Its dynamic correlations with WTI continually move between 0.05 and 0.55 without any identified regime change, reflecting its safe-haven status.

As for total Non-Energy commodities, indices for Non-Energy commodity groups are constructed using equally-weighted commodity futures returns for each group. For robustness, we also apply an alternative measure using GSCI sub-index weights. ${ }^{12}$ Results are qualitatively similar and robust with the two alternative definitions of constructed indices (Figure 12). Furthermore, as a second robustness check, we estimate dynamic correlations between the available Non-Energy GSCI sub-indices, namely GSCI Industrial metals, Agriculture, Livestock and Precious Metals, and WTI. Once again, our estimations give very similar results to those from constructed indices (Figure 13 in Appendix C).

To further reveal commodity-specific characteristics, we decide to analyze each Non-Energy commodity-WTI correlation pair estimated using bivariate models, as a complement to the total and group analyses. The specific and independent switching dynamics of each pairwise correlation were examined. As expected, the timeline of the sub-figures in Figure 4 indicates a variety of commodity-WTI correlations in switching dynamics. More precisely, smoothed probabilities (Appendix C) show that for some bivariate estimations, three regime changes are detected (Figure 14), while only two regimes are identified for the others (Figure 14). The common feature of NonEnergy individual commodity futures returns, except for barley, sunflowers and orange juice, is the steep jump in their correlations with WTI coinciding with either the financial crisis or the demise of Lehman Brothers. This confirms findings by Tang and Xiong $(2010,2012)$ that the correlation of Non-Energy commodities with WTI has increased, which is interpreted as evidence of the financialization of commodities. This is reinforced by the finding that individual Off-index commodities, such as barley and sunflowers, are totally disconnected with WTI, with correlations fluctuating around zero. Unlike previous studies, moreover, our results show the temporary nature of the recent hike in these correlations, which is due to the temporary large shock from

\footnotetext{
${ }^{11}$ Transition matrix and smoothed probability clearly show the absence of a third regime. Results are available upon request.

${ }^{12}$ Weight for each commodity is calculated on the basis of rescaled weight of corresponding commodity sector.
} 

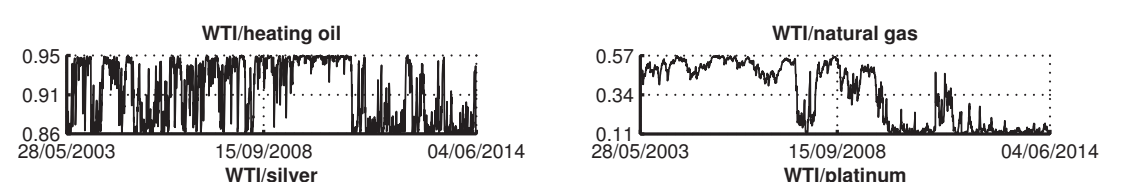

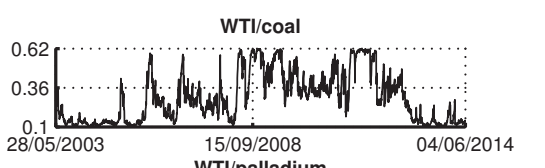

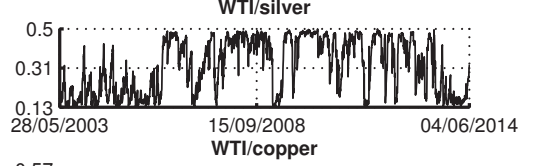
${ }_{20.06}^{0.28}{ }_{2805 / 2003}^{0.51}$

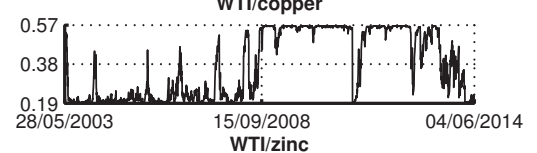

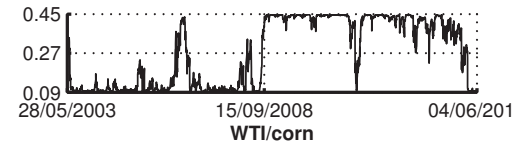

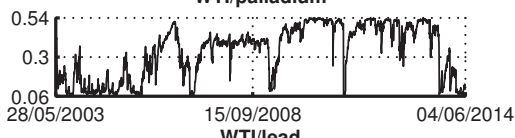

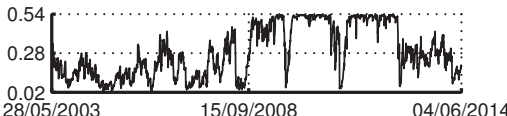
28.14

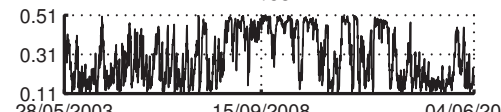

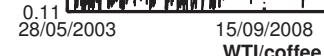

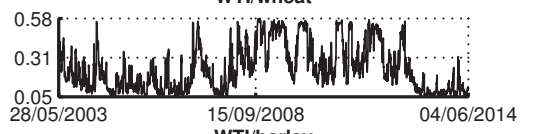
o. ${ }_{28 / 05 / 2003}^{0.04}$

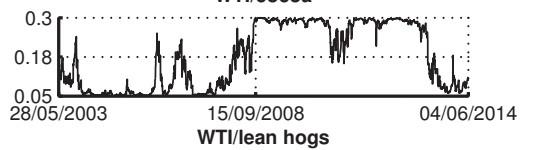
28/05/2003 15/09/2008 04/06/2014 28/05/2003

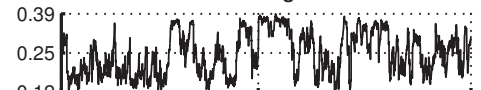
28/105/2003 $\begin{array}{ccc}0.12 \\ 28 / 05 / 2003 & \begin{array}{c}15 / 09 / 2008 \\ \text { WT/live cattle }\end{array} & 04 / 06 / 2014\end{array}$
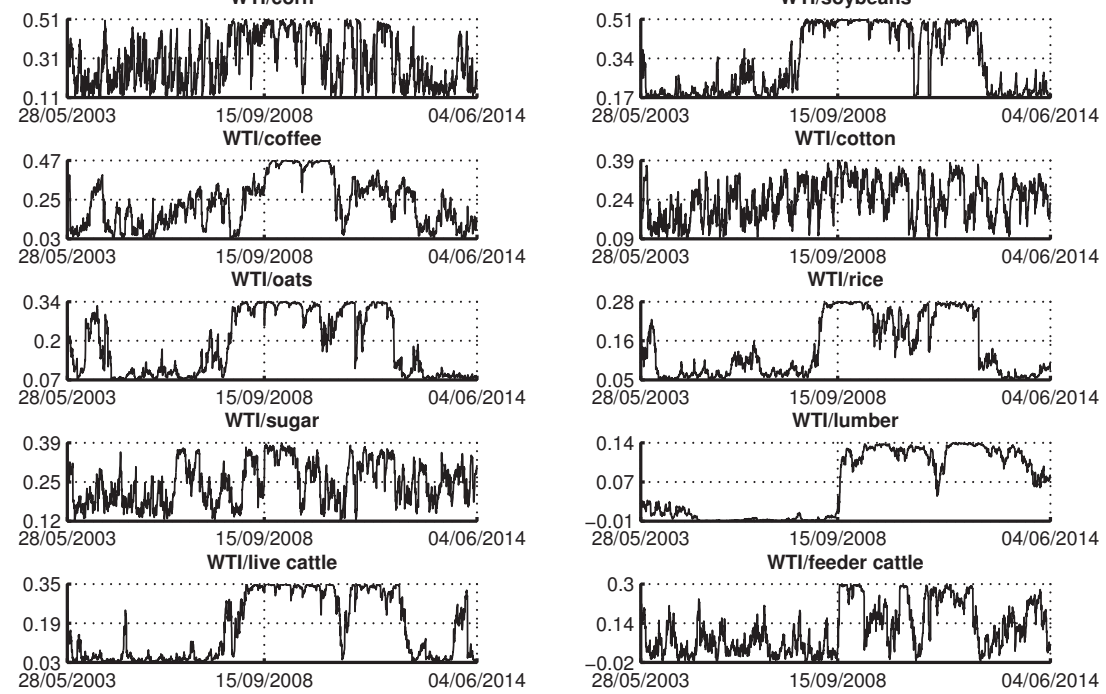

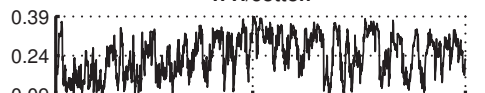
${ }_{2809}^{0.09 / 2003} \frac{1}{15 / 09 / 2008}$

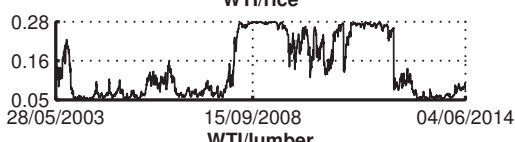

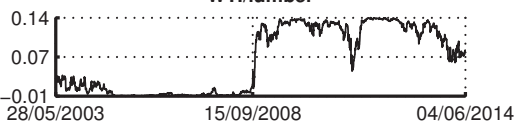
(u)

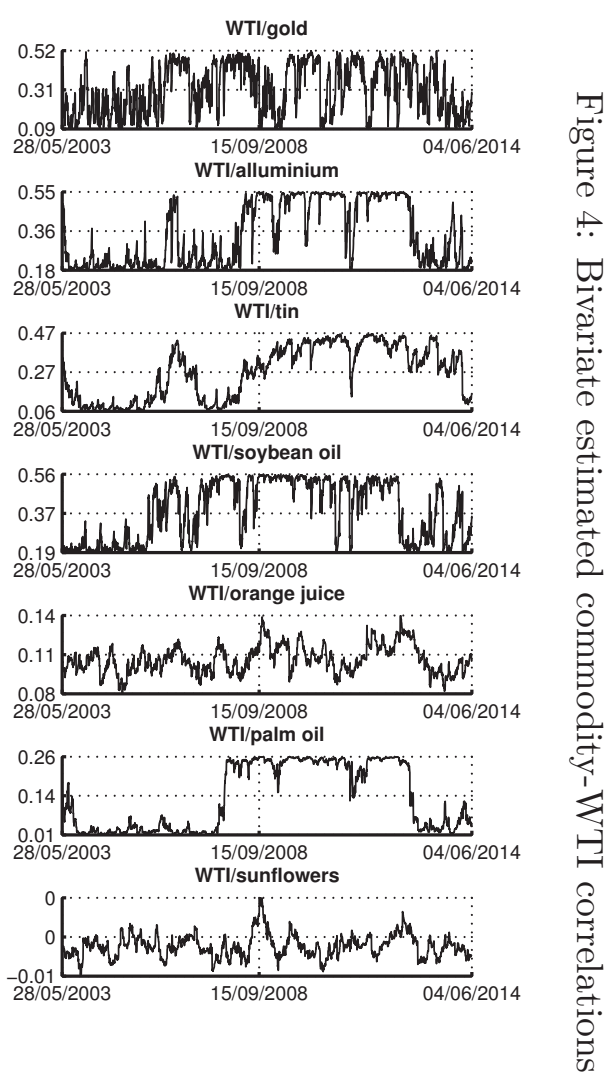


the financial crisis, as several agricultural, soft and oil individual futures return correlations return to their pre-crisis levels.

This is more consistent with the notion of a "market-of-one" and the "loss spiral" theory whith investors facing fire sales of liquid risky assets during periods of high volatility in financial markets. Interestingly, individual Industrial Metals commodities exhibit remarkable similarity, both with their group and with each other, in terms of timing of the change across regimes and the correlation spread value between low and high correlation regimes. The common turning point corresponds to the demise of Lehman Brothers, after which the higher correlations regime seems to be persistent, except for aluminum and zinc. On the other hand, correlations between individual Off-index commodity futures returns, except palm oil, with WTI are consistent with the expected theoretical findings and results from total Off-index commodities. Palm oil, however, behaves exactly like In-index commodity futures: its correlation with WTI sharply increases during the financial crisis period, reverting to its low level by the end of September 2012.

\section{Co-movements between commodities and traditional assets}

Several previous empirical studies examine the co-movement between commodity and equity returns with the objective of judging the diversification benefits of commodity futures as alternative assets in portfolios and assessing whether or not commodity and financial markets are becoming more closely integrated (Jensen et al. (2000), Erb and Harvey (2006), Chong and Miffre (2010), Tang and Xiong (2010), Choi and Hammoudeh (2010), Büyükşahin et al. (2010), Silvennoinen and Thorp (2013), and Büyükşahin and Robe (2014)). In this section we first examine the dynamic correlation between commodities and the S\&P 500, and second, we conduct the same analysis for commodity-bond co-movements.

\subsection{Commodity-equity co-movements}

The focus on commodity-equity co-movements is justified by the large weight of stocks in the commodity index investors' portfolio. As explained in Tang and Xiong (2010), increasing investment in commodity indices may have two opposing effects on co-movements between commodity indices and traditional asset returns such as stocks, depending on index investors' rebalancing strategies and the composition of their portfolios. On the one hand, commodity index trading can act as a channel of higher correlations with equities in a portfolio, as index investors, having incentives to maintain their portfolio diversification level, rebalance their portfolios between commodities and stocks when shock alters portfolio weights (Basak and Pavlova (2013)). On the other hand, portfolio composition switches between commodities and stocks can generate a weak and even negative correlation between the two different asset classes. This effect ties in with the "style effect" theory (Barberis and Shleifer (2003)), which considers this negative correlation as a consequence of the style competition caused by the externality generated by switcher investors. To sum up, the overall commodity-equity co-movement reaction may depend on the combined effect of these two opposing forces, or on whether positive or negative effects prevail.

However, in times of financial crisis, regardless of the above effects, correlations may sharply increase between different asset classes comprising investors' portfolios, particularly between commodities and equities, the largest segment of investors' portfolios (Kyle and Xiong (2001) and Brunnermeier and Pedersen (2009)).

First, we present estimation results on commodity index-equity correlations using the four most popular commodity indices. Secondly, based on the above theories, we take a closer look at commodity-equity correlations through estimations using individual commodity futures returns. 
Figure 5: Commodity indices and the S\&P 500
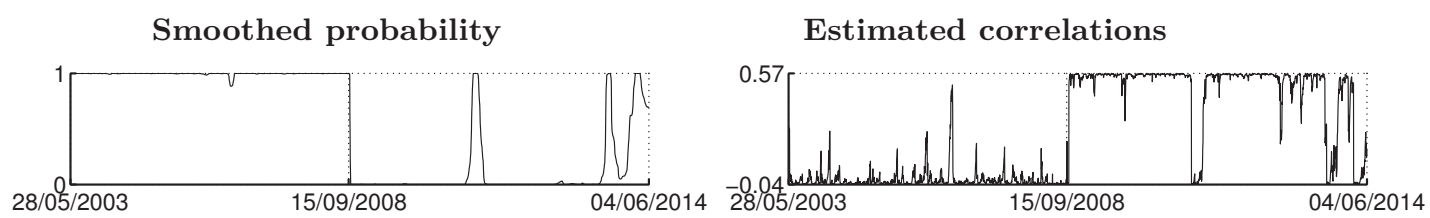

(a) GSCI/SP500

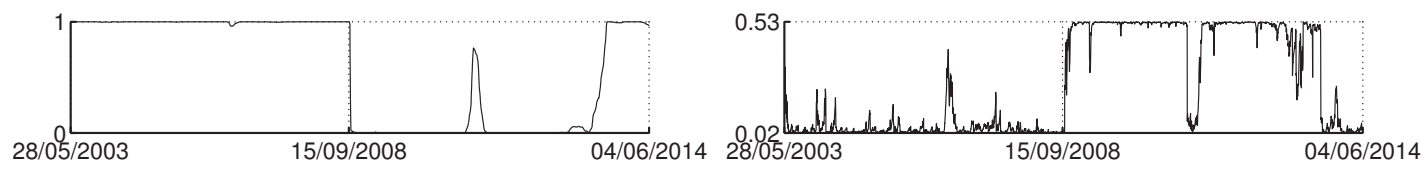

(b) DJUBS-SP500

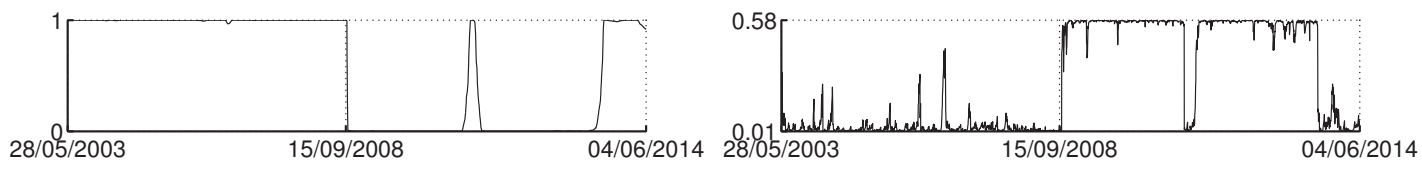

(c) RJ-CRB/SP500

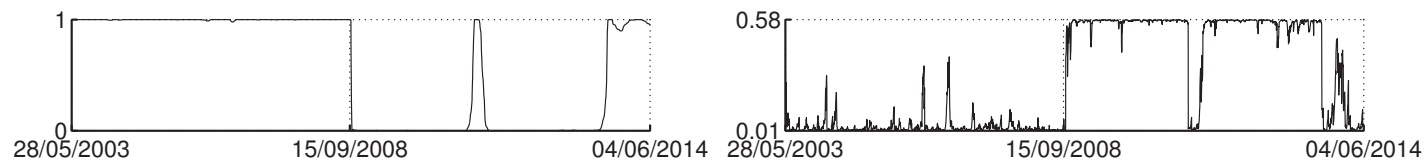

(d) RICI-SP500

Note: this figure plots the estimated smoothed probability (left) and dynamic correlation of commodity indices returns with S\&P 500 (right), using daily data between May 28, 2003 and June 4, 2014. Results indicate two dynamic correlation switching regimes, regime One referring to the weaker correlation regime.

\subsubsection{Commodity indices and the S\&P 500}

Figure 5 shows pairwise correlations among all four equity-commodity indices, namely GSCI, DJ-UBS, RJ-CRB and RICI. ${ }^{13}$ Smoothed probabilities between the S\&P500 and different indices follow a similar pattern, indicating a regime change precisely in September 15, 2008 following the Lehman bankruptcy. As indicated in the previous section, we estimate our model with no restriction on the number of regimes, and our estimations clearly support the existence of only two regimes. As we can see, during regime One, dynamic correlations between commodity indices and the S\&P 500 are very low and even negative for the GSCI index, except for some insignificant fluctuations, before the dramatic upsurge to more than 0.5 in regime Two. This is in agreement with the findings of Gorton and Rouwenhorst (2006), Büyükşahin et al. (2010) and Büyükşahin and Robe (2014), but contrary to those of Tang and Xiong (2010), who find that the correlation between the GSCI index and the S\&P500 started to increase from 2004. As explained in Büyükşahin and Robe (2014), the rolling correlation technique can lead to biased estimation due to sensitivity to volatility. These results are therefore more consistent with the "style effect" theory, which documents the very weak correlation between competing asset classes or "styles", and their robustness to different commodity indices consequently runs counter to the theoretical findings of Basak and Pavlova (2013).

Evidence that the commodity-equity returns correlation was negligible prior to September 2008 and has increased sharply since then is not new, being frequently found in the literature (Gorton and Rouwenhorst (2006), Büyükşahin et al. (2010) and Büyükşahin and Robe (2014)). Our work clearly identifies a regime change in commodity-equity correlations, corresponding exactly to the Lehman Brothers collapse on September 15, 2008 when the prices of most tradable

\footnotetext{
${ }^{13}$ We also estimate equity correlations with GSCI sub-indices. The focus on the GSCI index is justified by its very high market share (63\%). Results from sub-indices (Figure 16), especially GSCI Energy, are similar to those from the GSCI index, except for GSCI Precious metals, confirming the status of precious metals as a safe haven.
} 
assets simultaneously experienced sharp declines within the same day. This correlation shift can be attributed to Büyükşahin et al. (2010)'s notion of a "market of one" which is in line with the "loss spiral" theory of Brunnermeier and Pedersen (2009) during turbulent periods.

Most importantly, our work advances the debate by providing, for the first time, a clear-cut response to the frequently asked question of whether the financial crisis effect on commodity-equity correlations is temporary or permanent. It is worth noting that regime One, which corresponds to the weak correlation regime, shows up once simultaneously for all commodity indices during the tranquil period between the two VIX spikes in May-October 2010 and August 2011-April 2012, before becoming established since April 2013. Correlations then revert to their pre-crisis level as implied by the "loss spiral" theory, emphasizing the temporary nature of the financial crisis effect on commodity-equity correlations.

\subsubsection{Individual commodity futures returns and S\&P 500}

We now turn to the analysis of individual commodity futures return correlations with the S\&P500. Our main interest is in determining whether or not individual commodity futures correlations with the S\&P 500 behave differently from those of their corresponding indices. This allows us to gauge the effect of the financialization process on commodity futures returns and to complete the picture related to the "style" investment theory, since the commodity index constituents should have weak or negative correlations with other competing asset classes.

Figure 6: Total commodities with S\&P 500

Smoothed probability

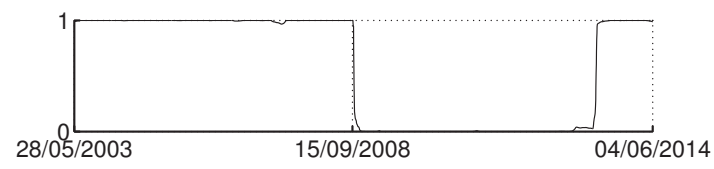

(a) Total commodities/S\&P 500

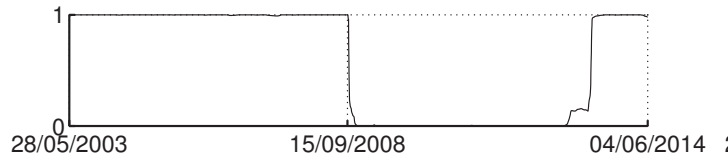

(b) In-index/S\&P 500

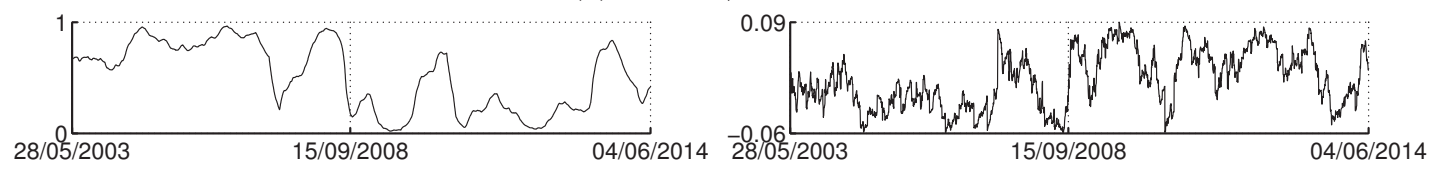

(c) Off-index/S\&P 500
Estimated correlations

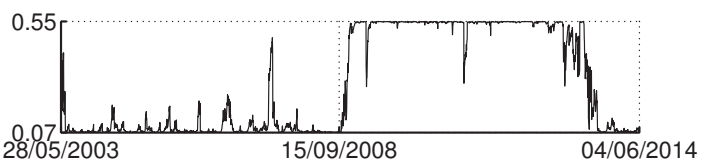

Note: this figure plots the estimated smoothed probability (left) and dynamic correlation of the equally-weighted indices of commodity futures returns with S\&P 500 (right), using daily data between May 28, 2003 and June 4, 2014. Panel (a) contains results from the equally-weighted index constructed from the total commodity futures returns. Panels (b) and (c) contain results from the equally-weighted index constructed from In- and Off-index commodity futures returns. Results indicate two dynamic correlation switching regimes, regime One referring to the weaker correlation regime.

Figure 6 exhibits smoothed probabilities and correlations between individual commodities and the S\&P 500. ${ }^{14}$ Similar to our findings from commodity indices, our model detects only two dynamic correlations regimes with a significant regime shift on September 15, 2008, moving from close to zero to 0.55 . Moreover, correlations reverted to the pre-crisis level at the same time, in April 2013.

\footnotetext{
${ }^{14}$ We use the same commodity index construction as in the previous section, namely an equally weighted index from individual commodity futures returns. In addition, our results are robust to the alternative construction method for indices using GSCI weights (see Figure 17).
} 
In addition, as Off-index commodity-equity correlations hover around zero across the sample without any clear regime change (sub-Figure 6c), the distinction between In- and Off-index commodity futures returns sheds light on two important issues. First, regarding the period preceding the financial crisis, the absence of correlation with equities further confirms the relevance of the "style" theory compared to the rebalancing portfolio argument, which postulates that even Off-index commodity-equity correlations increase, although to a lesser degree than In-index commodity-equity correlations. Second, this result further supports the "loss spiral" theory since, contrary to In-index, Off-index commodity correlations with stock returns remain negligible during the financial crisis. This is consistent with the fact that only In-index commodity futures, which are bought and sold by commodity index providers to offset their net position, are subject to selling pressure during the turbulent period.

Figure 7: Commodity groups with S\&P 500

Smoothed probability

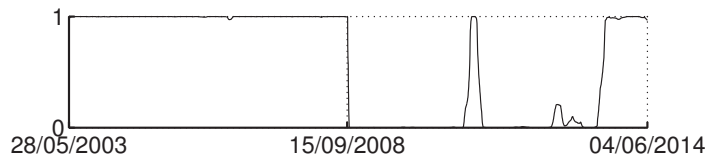

(a) Energy/SP500

Estimated correlations
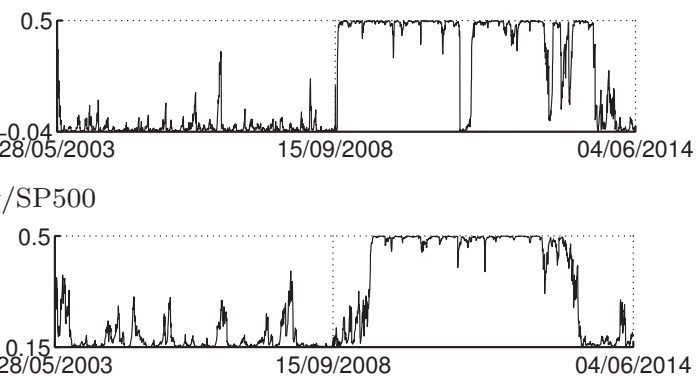

(b) Industrial metals/SP500

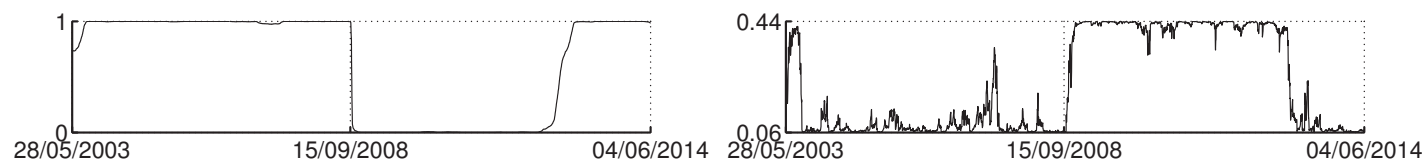

(c) Agriculture/SP500

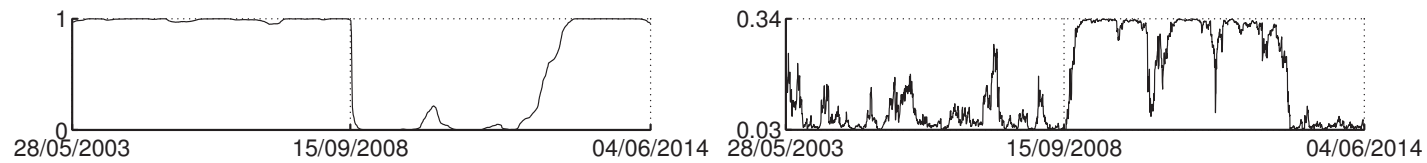

(d) Grains/SP500

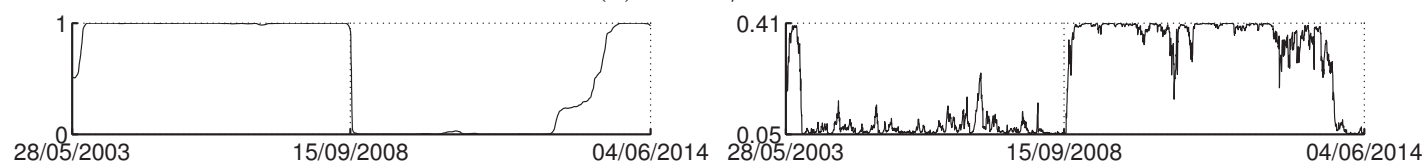

(e) Softs/SP500

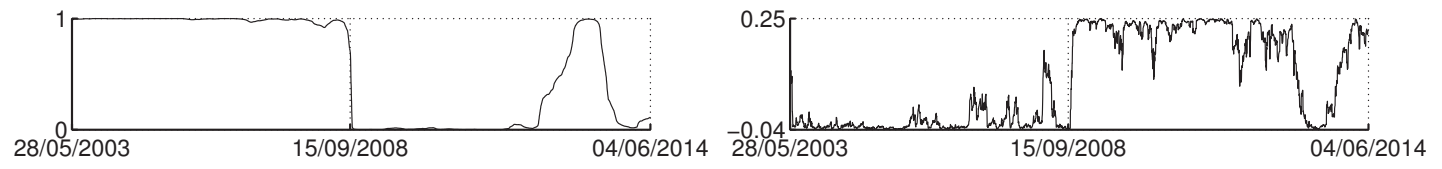

(f) Livestock/SP500

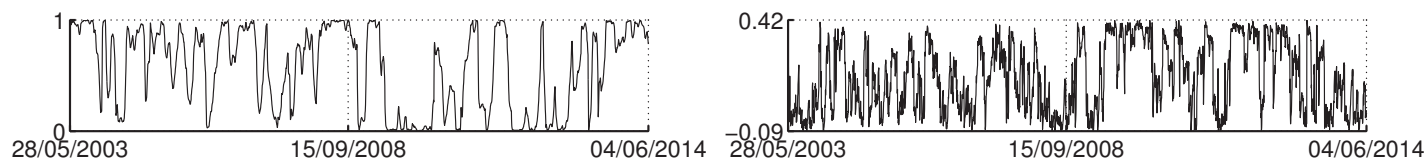

(g) Precious Metals/SP500

Note: this figure plots the estimated smoothed probability (left) and dynamic correlation of the equally-weighted indices returns, constructed from commodity futures groups (as defined in Section 3), with S\&P 500 (right), using daily data between May 28, 2003 and June 4, 2014. For instance, Panel (a) contains results from the equally-weighted index constructed from industrial metals commodity futures returns. Results indicate two dynamic correlation switching regimes, regime One referring to the weaker correlation regime. 
The goal now is therefore to understand whether there is heterogeneity between commodity group co-movements with the S\&P 500. Figure 7 exhibits commodity-equity correlations for each group, namely Industrial Metals, Energy, Agriculture, with a distinction between Grains and Softs, Livestock and Precious Metals. ${ }^{15}$ The Energy group correlations (Figure 7a) stands out because of its remarkable similarity with the commodity indices-equity correlation in Figure 5, in terms of synchronized structure change and particularly the common decline in their correlations with the S\&P 500 between February 2011 and April 2011. This decline in correlation is most likely related to the decline in the VIX during the period of calm between the two VIX spikes in MayOctober 2010 and August 2011-April 2012. Not being common to the other Non-Energy groups, this suggests that the Energy group are the most financialized commodities, those most strongly integrated with equities, and therefore more dependent on events in global financial markets than on fundamentals. This is not surprising, as the Energy group has the largest weight in commodity indices, especially the GSCI index (see Table 4 in Appendix A). Moreover, the negative correlation of this group with the S\&P 500 before the financial crisis (-0.04) is consistent with the "style" effect theoretical findings, suggesting that the Energy group is likely to be considered by investors as a fully-fledged "style" differentiated from other commodity groups.

Also noteworthy in sub-Figure $7 \mathrm{~b}$ is the timing of the Industrial Metals group correlation regime change, as correlation increases sharply in May 2009, well after the demise of Lehman Brothers. ${ }^{16}$ This means that Industrial Metals commodity futures returns were not impacted by fire sales on the eve of the current financial crisis. The similarity between these results and those from the GSCI Industrial metals sub-index (Figure 18a in Appendix D), together with the difference between the latter two results and those from commodity indices (Figure 5), indicate that investors do not consider all commodities jointly as a fully-fledged asset-class. Rather, investors seem to distinguish between commodity groups, thereby justifying the sub-indices offered by most institutions, such as S\&P Goldman Sachs or Dow-Jones UBS. Index investors, therefore, may not have considered Industrial Metals commodities as riskier assets, the latter not being among the assets sold in fire sales immediately after the Lehman Brothers collapse. One plausible explanation of investor behavior is the emerging market economies' growing demand for these commodities, which positively influenced risk perception regarding these assets. This appears to have been sufficient to offset the expected sharp price decline following the mass selling on commodity indices. However, as the financial crisis started to affect the world's real economy, the demand on Industrial Metals commodities and therefore their prices experienced a sharp decline, which in turn sharply increased correlations with equities in May 2009. Moreover, we can observe the relatively high correlation (0.15) between this group and equities during the low correlation regime compared to the other groups. The rebalancing portfolio argument in Basak and Pavlova (2013) and Tang and Xiong (2010) may appear to better explain these results. However, as all the other results from commodity indices-equities clearly support the "style" argument, we can only think that economic fundamentals still largely explain returns movements of Industrial Metals commodities.

Correlation between the Agriculture group and equities follows a similar path to that of its corresponding GSCI sub-index. The inflection point of a very weak and a sharp rise in correlations coincides with the Lehman Brothers default, with a reversion to the pre-crisis level at the end of the sample in April 2013. A difference in reversion date emerges, however, when we distinguish between the Grains and Softs groups. The Livestock group has the same pattern as Agriculture and Energy, with the only difference, but one that is significant, occurring at the end of the sample:

\footnotetext{
${ }^{15}$ For robustness, we estimate correlations between equities and alternative indices constructed from commodity groups using GSCI weights; results, provided in Appendix D, remain quite similar to those from equally-weighted group indices. There is a remarkable similarity between results from both definitions of commodity group indices and the corresponding GSCI sub-indices, except for Grains and Softs as GSCI do not provide a sub-index for Grains and GSCI Softs is available only as from 2008.

${ }^{16} \mathrm{~A}$ similar correlation trend can be seen with both the index constructed using GSCI weights (Figure 17) and the sub-index GSCI Industrial Metals (Figure 18a)
} 
the correlation seems to revert to crisis regime after a sharp decrease in mid-2013. Finally, results on correlations between the Precious Metals group and equities confirm once more the safe-haven status of Precious Metals commodities.

Overall, two major features are brought to light by the commodity group analysis. First, commodity index investors do distinguish between commodity groups and do not consider all commodities jointly as an asset class. Second, there is substantial heterogeneity among commodity groups, and Energy and Industrial Metals are special cases.

Figure 8 takes a closer look at commodity-equity correlations to reveal more features of correlation dynamic switching and magnitude by estimating bivariate models. ${ }^{17}$ Three major findings emerge form this analysis. First, as Figure 8 shows, the commodity futures returns with the largest weight, especially the GSCI index, seem to govern the dynamic correlation paths with the S\&P 500 of their corresponding groups and any sub-indices. This applies to WTI, aluminum and copper, corn and soybeans, gold and live cattle ${ }^{18}$, and is consistent with the fact that these commodities are more subject to the financialization process. Second, despite some observed differences in behavior, bivariate estimations show a high degree of homogeneity among commodities belonging to the same group in terms of correlation with equities. Moreover, commodities which behave differently are either Off-index commodities, namely barley and sunflowers, or belong only to the RICI and RJ/CRB indices, like tin, rice, oats, lumber and orange juice ${ }^{19}$. For these commodities, fundamentals, seasonality and specific physical market factors appear to remain determinant factors. Third, as regards Precious Metals commodities, whereas gold and silver seems to play their traditional role as safe-haven assets, platinum and palladium behave like Industrial Metals: their correlations with equities remain very weak (0.05 and 0.08) until 2009, subsequently increasing markedly (0.45). This is consistent with the fact that the most of the demand for platinum and palladium (more than $80 \%$ ) is attributable to the industrial sector, in particular the automotive industry.

\subsection{Commodity-bond co-movements}

Although S\&P 500 stocks and commodities represent a large fraction, institutional investors' portfolios include a certain amount of value and growth stocks, small, medium and large capitalization stocks, US Treasury-bonds and Treasury-bills, and international assets. ${ }^{20}$

Some attention has also been paid in the literature to co-movements between commodities and bonds (Chong and Miffre (2010) and Silvennoinen and Thorp (2013)). This section focuses on correlation between commodities and US bonds in order to explore commodity co-movements with another asset class such as fixed-income assets. It extends these works, both by including more commodity futures and commodity indices in the analysis and by using a longer time series of data extending beyond the financial crisis. Despite their smaller weight in investor portfolios, the "style effect" theory should hold for bonds as a competing asset, suggesting a weak commoditybond correlation. However, during periods of financial turmoil like the recent financial crisis, and contrary to stocks, the "loss spiral" argument does not hold. Investors actually become more risk averse and tend to reduce their exposure to riskier assets, such as stocks, favoring safer assets such as government bonds. We would therefore expect this asset class to behave differently from commodities.

\footnotetext{
${ }^{17}$ In this respect in particular, the study most similar to ours is Silvennoinen and Thorp (2013) whose results differ from ours, except for energy commodities, either in correlation magnitude and/or in regime changes. This is mainly due to the difference in estimation approaches.

${ }^{18}$ For more details about commodity weights you can see Table 4 in Appendix A.

${ }^{19}$ Natural gas correlation with equity remains close to zero throughout the sample, showing a very different path compared with those of WTI and heating oil. This is the only commodity belonging to all major commodity indices showing such different behavior. This result is similar to that found in Silvennoinen and Thorp (2013).

${ }^{20}$ More details about institutional allocation across assets are given in Gonnard et al. (2008) and Tonello and Rabimov (2010).
} 


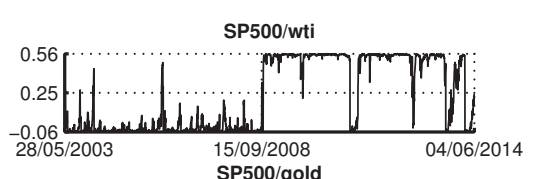

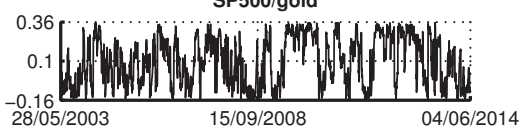

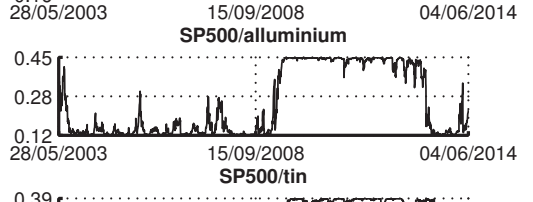

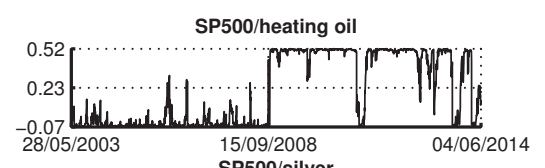
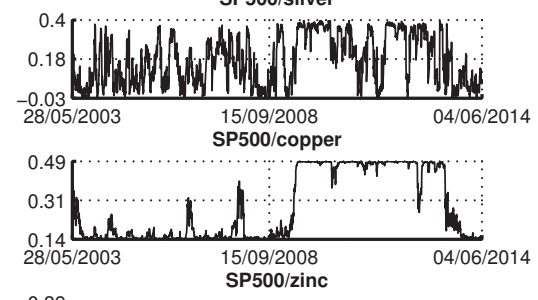

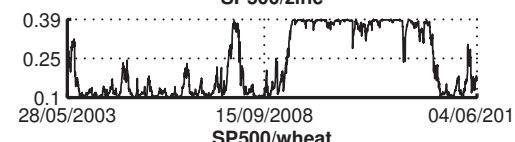

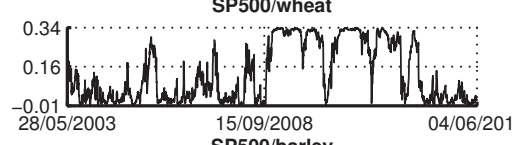

SP500/barley

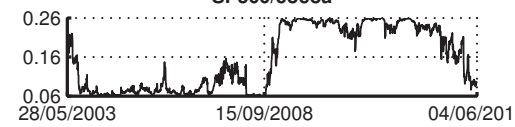

$\begin{array}{cc}0.06 \frac{15}{2805 / 2003} & 15 / 09 / 2008 \\ \text { SP500/lean hogs }\end{array}$

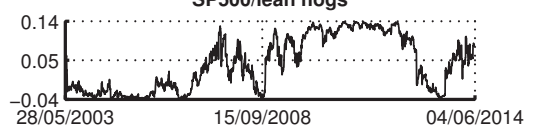

${ }_{-0.02}^{0.11}(\underset{28 / 05 / 2003}{\text { SP500/natural gas }}$

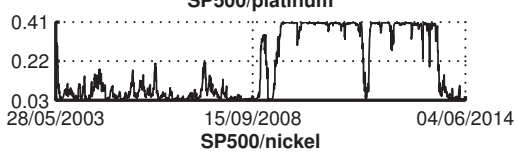

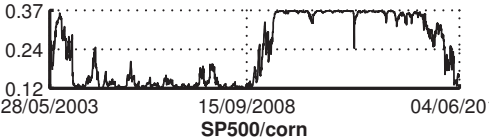

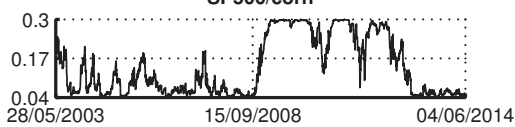

$\begin{array}{ll}0.04 & 15 / 09 / 2008 \\ 28 / 05 / 2003 & \text { SP500/coffee }\end{array}$

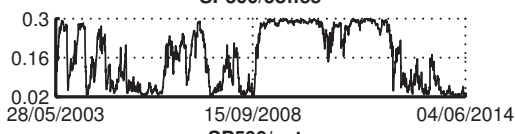

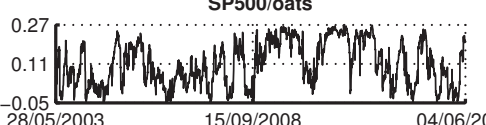

$\frac{-0.05}{28 / 05 / 2003} \frac{04 / 06 / 2014}{15 / 09 / 2008}$

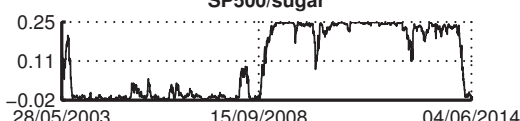

$\begin{array}{ccc}-0.02 & 15 / 09 / 2003 / 2008 & 04 / 06 / 2014 \\ \text { SP500//ive cattle }\end{array}$

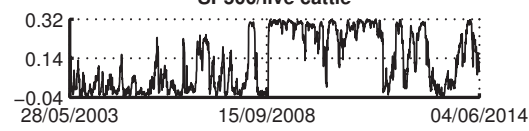

SP500/palladium

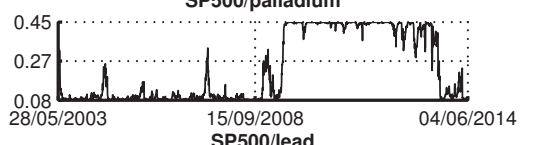

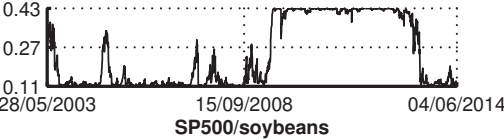

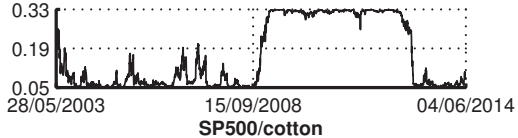

SP500/cotton
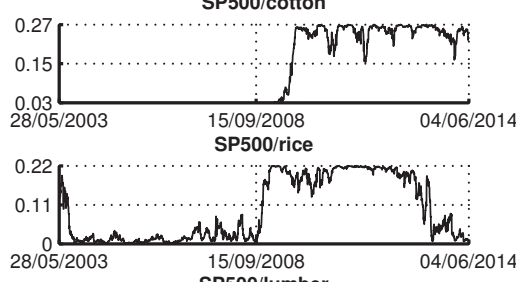

SP500/lumber

${ }_{28,05 / 2003}^{0.13}{ }_{15 / 09 / 2008}^{0.13}$

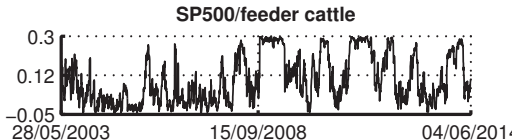


Figure 9: Commodity indices and US Bonds
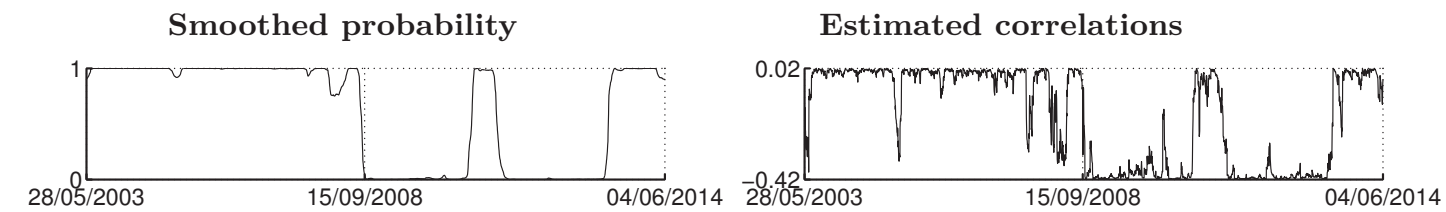

(a) GSCI/US Bonds
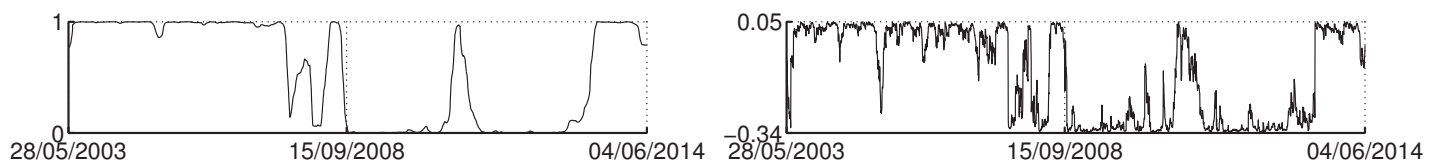

(b) DJUBS/US Bonds

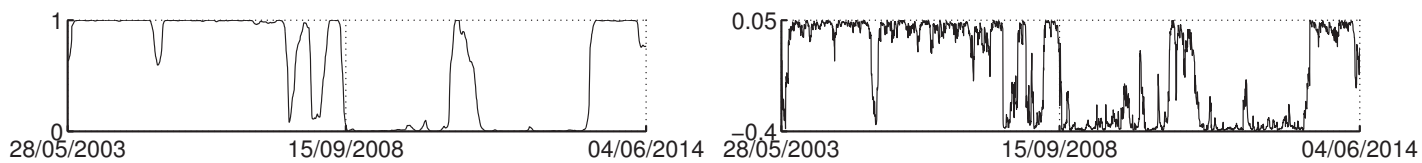

(c) JF-CRB/US Bonds

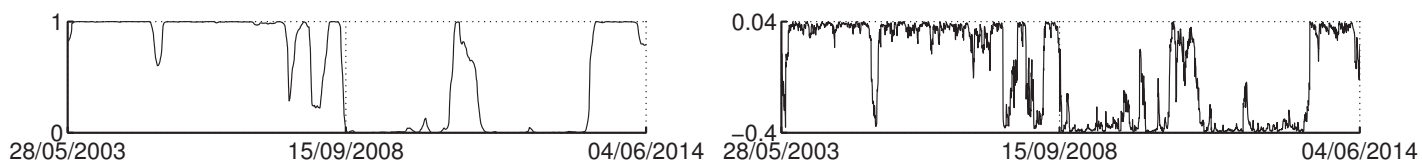

(d) RICI/US Bonds

Note: this figure plots the estimated smoothed probability (left) and dynamic correlation of commodity index returns with US Bonds (right), using daily data between May 28, 2003 and June 4, 2014. Panels (a)-(d) represent results for GSCI, DJ-UBS, RJ/CRB and RICI indices, respectively. Results indicate two dynamic correlation switching regime; while regime One refers to the weak, but positive, correlation regime, regime Two refers to a high and negative correlation regime.

Results from commodity index-US bond correlations in Figure 9 reveal at least three interesting features. The period until September 15, 2008 exhibits a very weak commodity index correlation with US bond returns (about 0.03 on average). This is consistent with the financialization and the "style effect" arguments, as discussed above. What is more interesting is the fact that correlations sharply decrease to a negative regime (about -0.4) on the eve of the Lehman bankruptcy, before returning to pre-crisis level in April 2013. As expected, the negative correlation regime (regime Two) may reflect the flight-to-quality notion: investors considered government bonds as refuge securities in this turbulent period. ${ }^{21}$

The common significant spike shown in sub-figures 9a, 9b, 9c and 9d occurring between July 2010 and March 2011 corresponds to the period of calm when the VIX is almost at the same low level as before the financial crisis. ${ }^{22}$ This further confirms the refuge status of US bonds, as during this relatively short period of calm, correlations with commodities matched pre-crisis levels. Finally, the correlation reversion to pre-crisis level in April 2013 confirms results from commodity-equity correlations regarding the temporary nature of the financial crisis effect.

Figure 10 exhibits smoothed probabilities and correlations between equally-weighted commodity indices and US bonds. Results from correlations between bonds and indices for both total and In-index commodities (sub-Figures 10a and 10b) show exactly the same patterns and exactly resemble results from commodity indices. Importantly, sub-Figure 10c shows that correlations

\footnotetext{
${ }^{21}$ Moreover, as we expected, this phenomenon is not restricted to the relationship between bond and commodities. Although not reported in the paper, bond-equity correlations exhibit the same pattern with positive, but small, correlations before the financial crisis and a highly negative correlation regime starting in fall 2008, which is consistent with the findings of Engle and Sheppard (2001) and Andersen et al. (2007). This confirms the "market of one" view of equity and commodity markets which are simultaneously subject to the flight-to-quality phenomenon.

${ }^{22}$ Results from US Bond correlations with Energy and Industrial Metals GSCI sub-indices (Figure 18), show a similar pattern to the GSCI index, whereas those with GSCI Agriculture, Livestock and Precious Metals sub-indices behave differently.
} 
between Off-index commodities remain negligible and constant at -0.2 over time. Once again, this result supports the crucial role of the financialization of commodity markets in impacting the price determination process.

Figure 10: Total commodities with US Bonds
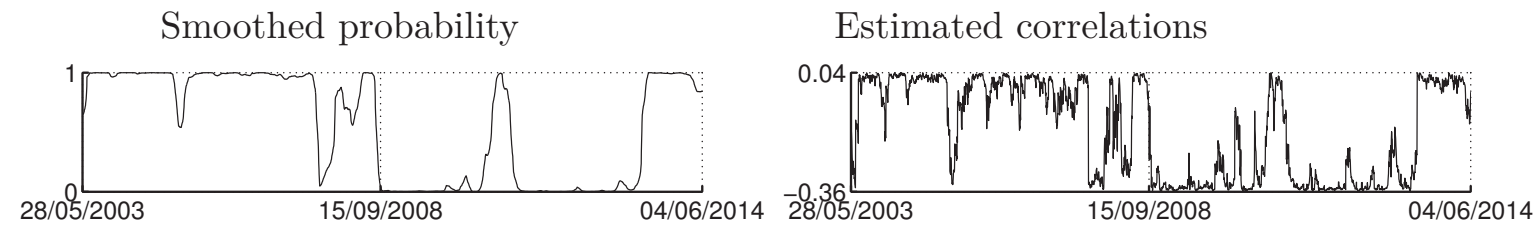

(a) Total commodities/US Bonds

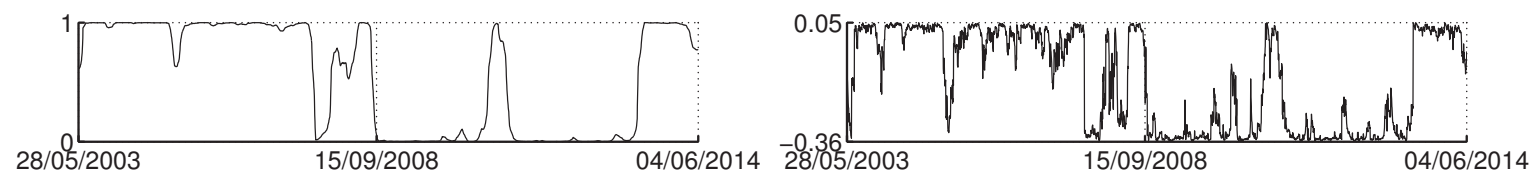

(b) In-index/US Bonds

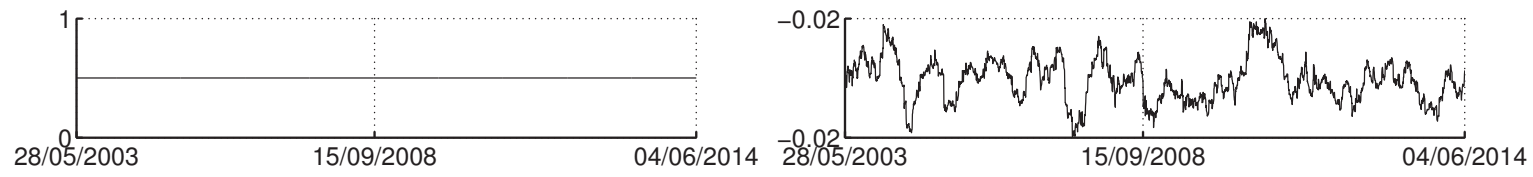

(c) Off-index/US Bonds

Note: this figure plots the estimated smoothed probability (left) and dynamic correlation of the equally-weighted indices of commodity futures returns with US Bond (right), using daily data between May 28, 2003 and June 4, 2014. Panel (a) contains results from the equally-weighted index constructed from the total commodity futures returns. Panels (b) and (c) contain results from the equally-weighted index constructed from In- and Off-index commodity futures returns. Results indicate two dynamic correlation switching regime; while regime One refers to the weak, but positive, correlation regime, regime Two refers to a high and negative correlation regime.

When estimating US Bond correlations with equally-weighted group commodity indices (Figure 19) ${ }^{23}$, we obtain the same results as with the corresponding GSCI sub-indices (Figure 18). We thus find some heterogeneity among commodity groups: in particular, no regime changes were detected for the Precious Metals and Livestock groups.

\section{Conclusion}

This paper examines co-movements across commodities and between commodities and traditional assets such as equities and bonds. In particular, we employ the RSDC methodology allowing for time variation in correlations matrices which evolve according to a regime switching process. We show how this methodology sheds light on different phases of correlation between seemingly unrelated commodities and between these commodities and traditional assets. To do so, we focus on the period before and after the rapid growth of index investment in commodities markets since early 2003, and before and after the recent financial crisis. Using a large data set of commodity futures contract prices and commodity indices, we are able to address numerous aspects of the correlation issue.

We detected strong integration among commodities concomitant with the financialization process due to heavy investment in commodity indices. Moreover, as in Tang and Xiong (2010, 2012), we find that correlations between Non-Energy commodities and WTI started to increase well before the recent financial crisis, indicating that the financialization process started impacting price movements of commodities before the recent turbulent period. However, our findings on correlations between commodities taken as an asset class and traditional financial assets as a

\footnotetext{
${ }^{23}$ We find the same results from constructed groups using GSCI weights (Figure 20).
} 
whole show very weak commodity-equity and commodity-bond correlations prior to the Lehman Brothers collapse. Weak correlation, however, does not necessarily mean weak integration. Here, the increasing commodity-equity correlations found during the financial crisis suggest, instead, strong integration among competing financial asset classes ("Styles"). This confirms the "style effect" theory that correlations between different asset classes in a portfolio weaken, and underlines the importance of financialization in current commodity price movements.

This paper suggests new avenues of research in commodity financialization. We demonstrate the need to use a non-linear model that takes into account changes in the financial sector and its interaction with the commodities sector. However, correlation, the focus of this paper, does not necessarily imply causality. A interesting question is, therefore, whether index investments impact commodity prices, and to what extent. To provide a complete picture of commodity financialization (or its absence), further analysis based on non-linear models should address the issue of causality. 


\section{References}

Andersen, T. G., Bollerslev, T., Diebold, F. X., Vega, C., 2007. Real-time price discovery in global stock, bond and foreign exchange markets. Journal of International Economics 73 (2), $251-277$.

Ang, A., Chen, J., 2002. Asymmetric correlations of equity portfolios. Journal of Financial Economics 63 (3), 443-494.

Barberis, N., Shleifer, A., 2003. Style investing. Journal of Financial Economics 68 (2), 161 - 199.

Barberis, N., Shleifer, A., Wurgler, J., 2005. Comovement. Journal of Financial Economics 75 (2), $283-317$.

Basak, S., Pavlova, A., 2013. A model of financialization of commodities. Working paper.

Bauwens, L., Laurent, S., Rombouts, J., 2006. Multivariate GARCH models : a survey. Journal of Applied Econometrics 21 (1), 79-109.

Billio, M., Caporin, M., 2005. Multivariate markov switching dynamic conditional correlation GARCH representations for contagion analysis. Statistical Methods and Applications 14 (2), $145-161$.

Bollerslev, T., 1990. Modelling the coherence in short-run nominal exchange rates: A multivariate generalized ARCH model. Review of Economics and Statistics 72, 498-505.

Brunnermeier, M. K., Pedersen, L. H., 2009. Market liquidity and funding liquidity. Review of Financial Studies 22 (6), 2201-2238.

Büyükşahin, B., Haigh, M., Robe, M., 2010. Commodities and equities: Ever a market of one? Journal of Alternative Investments 12 (3), 76-95.

Büyükşahin, B., Robe, M. A., 2014. Speculators, commodities and cross-market linkages. Journal of International Money and Finance 42 (C), 38-70.

Campbell, R., Koedijk, K., Kofman, P., 2002. Increased correlation in bear markets. Financial Analysts Journal 58 (1), 87-94.

Cappiello, L., Engle, R. F., Sheppard, K., 2006. Asymmetric dynamics in the correlations of global equity and bond returns. Journal of Financial Econometrics 4 (4), 537-572.

Chantziara, T., Skiadopoulos, G., 2008. Can the dynamics of the term structure of petroleum futures be forecasted? Evidence from major markets. Energy Economics 30 (3), 962-985.

Choi, K., Hammoudeh, S., 2010. Volatility behavior of oil, industrial commodity and stock markets in a regime-switching environment. Energy Policy 38, 4388-4399.

Chong, J., Miffre, J., 2010. Conditional correlation and volatility in commodity futures and traditional asset markets. Journal of Alternative Investments 12, 61-75.

Daskalaki, C., Skiadopoulos, G., 2011. Should investors include commodities in their portfolios after all? new evidence. Journal of Banking and Finance 35 (10), 2606 - 2626.

Engle, R., 2002. Dynamic conditional correlation - a simple class of multivariate GARCH models. Journal of Business and Economic Statistics 20, 339-350.

Engle, R., 2009. Anticipating Correlations. Princeton University Press. 
Engle, R., Sheppard, K., 2001. Theoretical and empirical properties of dynamic conditional correlation multivariate GARCH. Working Paper 2001-15, UCSD.

Erb, C., Harvey, C., 2006. The strategic and tactical value of commodity futures. Financial Analysts Journal 62:2, 69-97.

Francq, C., Zakoian, J., 2010. GARCH Models. Wiley, Chichester.

Gonnard, E., Kim, E. J., Ynesta, I., 2008. Recent trends in institutional investors statistics. OECD Journal: Financial Market Trends 2008 (2), 1-22.

Gorton, G., Rouwenhorst, G. K., 2006. Facts and fantasies about commodity futures. Financial Analysts Journal 62 (2), 47-68.

Haas, M., Mittnik, S., 2008. Multivariate regime-switching GARCH with an application to international stock markets. CFS Working Paper Series 2008-08, Center for Financial Studies.

Haas, M., Mittnik, S., Paollela, M., 2004. A new approach to markov-switching GARCH models. Journal of Financial Econometrics 2 (4), 493-530.

Hamilton, J., 1994. Time Series Analysis. Princeton University Press.

Hong, H., Yogo, M., 2011. What does futures market interest tell us about the macroeconomy and asset prices? Working Paper 16712, National Bureau of Economic Research.

Jensen, G. R., Johnson, R. R., Mercer, J. M., 2000. Efficient use of commodity futures in diversified portfolios. Journal of Futures Markets 20 (5), 489-506.

Kyle, A. S., Xiong, W., 2001. Contagion as a wealth effect. The Journal of Finance 56 (4), $1401-1440$.

Longin, F., Solnik, B., 2001. Extreme correlation of international equity markets. Journal of Finance 56, 651-678.

Pelletier, D., 2006. Regime switching for dynamic correlations. Journal of Econometrics 131 (1-2), $445-473$.

Silvennoinen, A., Teräsvirta, T., 2009. Multivariate GARCH models. In: Andersen, T., Davis, R., Kreiss, J., Mikosch, T. (Eds.), Handbook of Financial Time Series. Springer, New York.

Silvennoinen, A., Teräsvirta, T., 2009. Modeling Multivariate Autoregressive Conditional Heteroskedasticity with the Double Smooth Transition Conditional Correlation GARCH Model. Journal of Financial Econometrics 7 (4), 373-411.

Silvennoinen, A., Thorp, S., 2013. Financialization, crisis and commodity correlation dynamics. Journal of International Financial Markets, Institutions and Money 24, 42-65.

Singleton, K. J., 2012. Investor flows and the 2008 boom/bust in oil prices. Working paper.

Tang, K., Xiong, W., 2010. Index investment and financialization of commodities. NBER Working Papers 16385, National Bureau of Economic Research.

Tang, K., Xiong, W., 2012. Index investment and financialization of commodities. Financial Analysts Journal 68 (5).

Tonello, M., Rabimov, S., 2010. trends in asset allocation and portfolio composition. Tech. rep., The Conference Board:The 2010 Institutional Investor Report. 


\section{A Dataset}

Table 4: Commodity futures weights in the major commodity indices

\begin{tabular}{|c|c|c|c|c|c|c|c|}
\hline Commodities & Exchange & "Bloomberg Ticker & Contracts & GSCI & DJ-UBS & $\mathrm{RJ} / \mathrm{CRB}$ & RICI \\
\hline Energy & & & & $69.76 \%$ & $32.39 \%$ & $39 \%$ & $40 \%$ \\
\hline WTI crude oil & NYM & CL1-CL15 & Every month & $24.71 \%$ & $9.20 \%$ & $23 \%$ & $16 \%$ \\
\hline Heating oil & NYM & HO1-HO15 & Every month & $6.17 \%$ & $3.52 \%$ & $5 \%$ & $1.80 \%$ \\
\hline Natural gas & NYM & NG1-NG15 & Every month & $2.02 \%$ & $10.42 \%$ & $6 \%$ & $5 \%$ \\
\hline Coal & NYM & QZ1-QZ10 & Every month & 0 & 0 & 0 & 0 \\
\hline Industrial Metals & & & & $6.75 \%$ & $16.95 \%$ & $13 \%$ & $14 \%$ \\
\hline Aluminum & LME & LMAHDS (03 and 15) & Every month & $2.13 \%$ & $4.91 \%$ & $6 \%$ & $4 \%$ \\
\hline Copper & LME & LMCADS (03 and 15) & Every month & $3.28 \%$ & $7.27 \%$ & $6 \%$ & $4 \%$ \\
\hline Lead & LME & LMPBDS (03 and 15) & Every month & $0.40 \%$ & 0 & 0 & $2 \%$ \\
\hline Nickel & LME & LMNIDS (03 and 15) & Every month & $0.58 \%$ & $2.24 \%$ & $1 \%$ & $1 \%$ \\
\hline $\operatorname{Tin}$ & LME & LMSNDS (03 and 15) & Every month & 0 & 0 & 0 & $1 \%$ \\
\hline Zinc & LME & LMZSDS (03 and 15) & Every month & $0.51 \%$ & $2.52 \%$ & 0 & $2 \%$ \\
\hline Precious Metals & & & & $3.25 \%$ & $7 \%$ & $11.1 \%$ & $7.1 \%$ \\
\hline Gold & CMX & GC1-GC12 & Mar, May, Jul, Sep, Dec & $3 \%$ & $10.81 \%$ & $6 \%$ & $5 \%$ \\
\hline Silver & CMX & SI1-SI13 & Mar, May, Jul, Sep, Dec & $0.49 \%$ & $3.89 \%$ & $1 \%$ & $4 \%$ \\
\hline Palladium & NYM & PA1-PA3 & Mar, Jun, Sep, Dec & 0 & 0 & 0 & $0.30 \%$ \\
\hline Platinum & NYM & PL1-PL5 & Jan, Apr, Jul, Oct & 0 & 0 & 0 & $1.8 \%$ \\
\hline Agriculture & & & & $15.29 \%$ & $30.72 \%$ & $34 \%$ & $30.4 \%$ \\
\hline 1- Grain & & & & $11.21 \%$ & $22.64 \%$ & $13 \%$ & $21.6 \%$ \\
\hline Corn & $\mathrm{CBT}$ & $\mathrm{C} 1-\mathrm{C} 11$ & Jan, Mar, May, Jul, Aug, Nov & $4.69 \%$ & $7.05 \%$ & $6 \%$ & $4.75 \%$ \\
\hline Soybeans & CBT & S1-S7 & Jan, Mar, May, Jul, Aug, Sep, Oct, Dec & $2.62 \%$ & $5.49 \%$ & $6 \%$ & $3.50 \%$ \\
\hline Rice & CBT & RR1-RR7 & Mar, May, Jul, Sep, Nov, Jan & 0 & 0 & 0 & $0.75 \%$ \\
\hline Barley & SFE-ASX & FY1-FY7 & Mar, May, Jul, Sep, Nov, Jan & 0 & 0 & 0 & 0 \\
\hline Oats & $\mathrm{CME}$ & O1-O5 & Mar, May, Jul, Sep, Dec & 0 & 0 & 0 & $0.50 \%$ \\
\hline Soybean oil & $\mathrm{CBT}$ & BO1-BO10 & Jan, Mar, May, Jul, Aug, Sep, Oct, Dec & 0 & $2.74 \%$ & 0 & $2 \%$ \\
\hline Palm oil & MDE & KO1-KO10 & Jan, Mar, May, Jul, Aug, Sep, Nov & 0 & 0 & 0 & 0 \\
\hline Sunflowers & SAF & SU1,SU2, SU4, SU5 & Mar, May, Jul, Sep, Dec & 0 & 0 & 0 & 0 \\
\hline Wheat & CBT & W1-W10 & Mar, May, Jul, Sep, Dec & $3.22 \%$ & $3.43 \%$ & $1 \%$ & $4.75 \%$ \\
\hline 2- Soft & & & & $3.97 \%$ & 8.08 & $21 \%$ & $8.8 \%$ \\
\hline Cocoa & $\mathrm{ICE}$ & $\mathrm{CC} 1-\mathrm{CC} 10$ & Mar, May, Jul, Sep, Dec & $0.23 \%$ & 0 & $5 \%$ & $1 \%$ \\
\hline Sugar & ICE & SB1-SB8 & Mar, May, Jul, Oct & $1.85 \%$ & $3.88 \%$ & $5 \%$ & $1 \%$ \\
\hline Coffee & $\mathrm{ICE}$ & $\mathrm{KC} 1-\mathrm{KC} 8$ & Mar, May, Jul, Sep, Dec & $0.82 \%$ & $2.44 \%$ & $5 \%$ & $2 \%$ \\
\hline Cotton & $\mathrm{ICE}$ & CT1-CT10 & Mar, May, Jul, Oct, Dec & $1.07 \%$ & $1.76 \%$ & $5 \%$ & $4.20 \%$ \\
\hline Lumber & $\mathrm{CME}$ & LB1-LB7 & Jan, Mar, May, Jul, Sep, Nov & 0 & 0 & 0 & $1 \%$ \\
\hline Orange juice & ICE & JO1-JO10 & Jan, Mar, May, Jul, Sep, Nov & 0 & 0 & $1 \%$ & $0.60 \%$ \\
\hline Livestock & & & & $4.96 \%$ & $5.12 \%$ & $7 \%$ & $3 \%$ \\
\hline Feeder cattle & CME & FC1-FC8 & Jan, Mar, Apr, May, Aug, Sep, Oct & $0.52 \%$ & 0 & 0 & 0 \\
\hline Live cattle & $\mathrm{CME}$ & LC1-LC7 & Feb, Apr, Jun, Aug, Oct, Dec & $2.62 \%$ & $3.28 \%$ & $6 \%$ & $2 \%$ \\
\hline Lean hogs & $\mathrm{CME}$ & LH1-LH9 & Feb, Apr, Jun, Aug, Oct, Dec & $1.58 \%$ & $1.90 \%$ & $1 \%$ & $1 \%$ \\
\hline
\end{tabular}

This table gives details of the 32 commodity futures contracts used in our study to calculate the daily log returns from May 28, 2003 to June 4, 2014. Commodity futures contracts are generic contracts which refer to as constructing continuous futures prices series from futures active contract data. For instance, CL1 is the WTI Generic 1st contract, based on a 1-month WTI contract. Exchange-traded commodity futures markets are given in the second column. The third and fourth column contain maturity months of futures contracts and their Bloomberg tickers and the last four columns report the market value weights of each individual commodity within the major commodity indices, principally Standard and Poor's Goldman Sachs Commodity Index (GSCI) and Dow Jones UBS Commodity Index (DJ-UBS)as well as Rogers International Commodity index (RICI) and Thomson Reuters/Jefferis CRB Index (CRB), as of 2013. As commodity futures expires every one to three months, indices need to specify a rolling rule to transfer weights of the futures from the expiring period's contract to the next available contract. The rollover schedules of the GSCI, DJ-UBS, RJ/CRB indices are business days 5-9, 6-10 and 1-4 respectively. For the RICI index, it runs from the day prior to the last RICI business day of the month to the first RICI business day of the following month (for more details see RICI handbook). Industrial metals are traded on LME and daily settlement prices are quoted for the futures contracts to a fixed maturity period of 3and 15-months. 


\section{B Correlation across commodities}

\section{B.1 Correlation across commodity groups}

Figure 11: Commodity conditional correlations by group

Smoothed probability

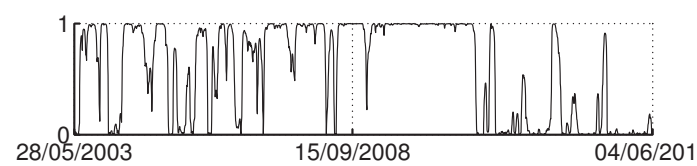

Estimated correlations

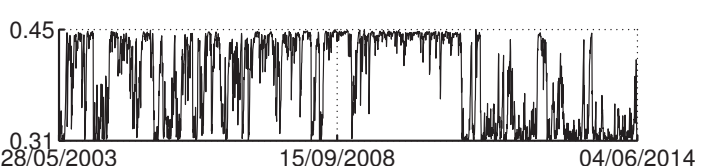

(a) Energy

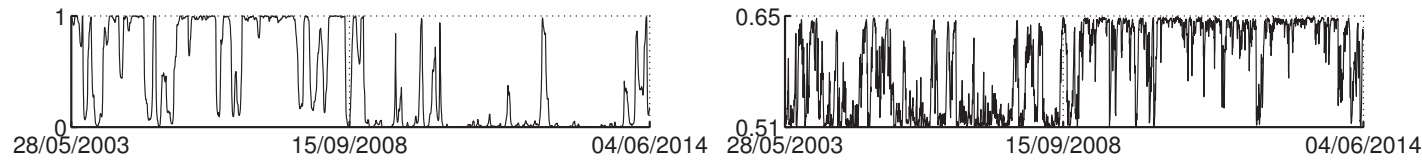

(b) Industrial Metals

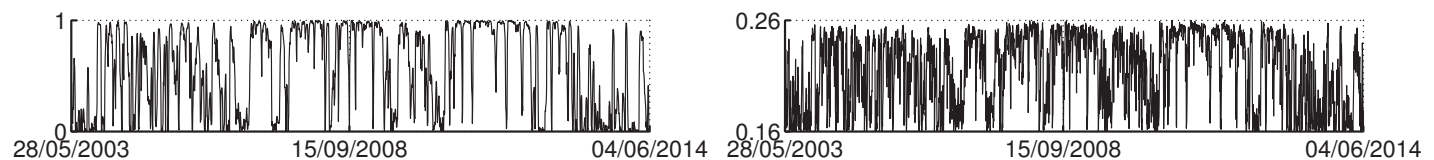

(c) Grains

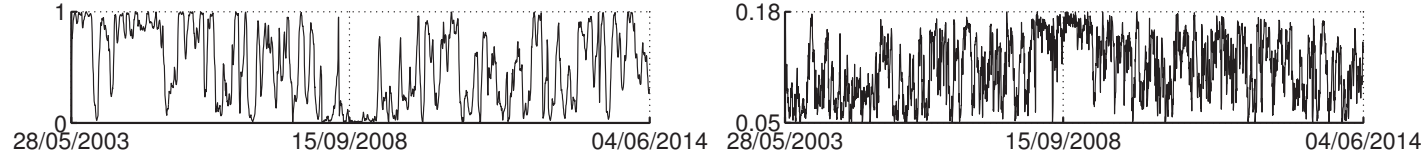

(d) Soft

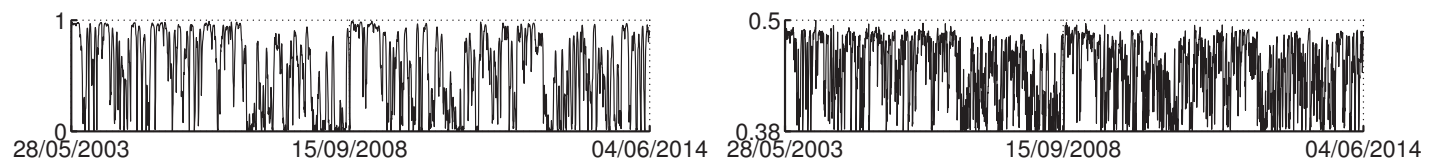

(e) Livestock

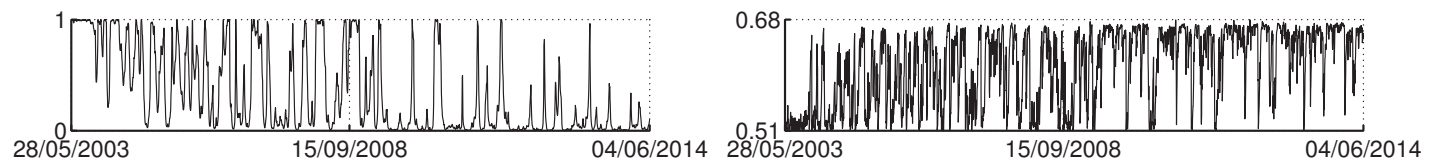

(f) Precious metals

Note: this figure plots the estimated smoothed probability (left) and equally average correlation pairs within groups (as defined in Section 3) of commodity futures daily returns (right), for the period between May 28, 2003 and June 4, 2014. Regime One, if any, refers to the weaker correlation regime.

B.2 GSCI groups and sub-indices correlation with WTI 
Figure 12: Commodity groups following GSCI weights with WTI

Smoothed probability

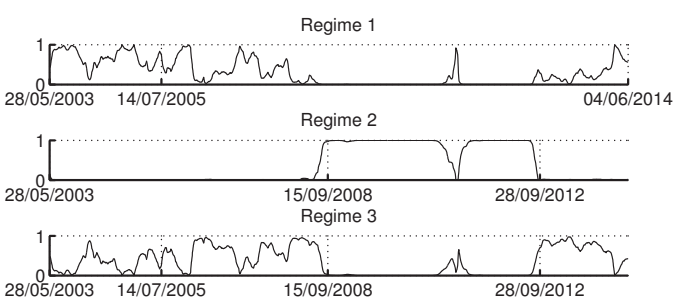

(a) Industrial metals/WTI

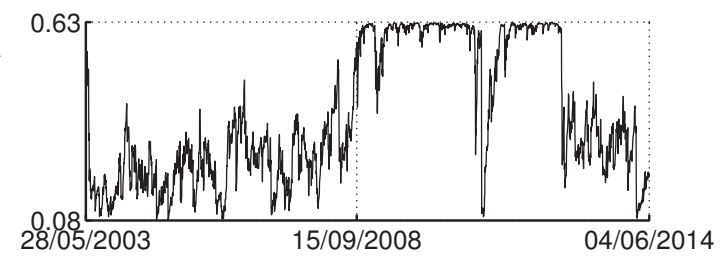

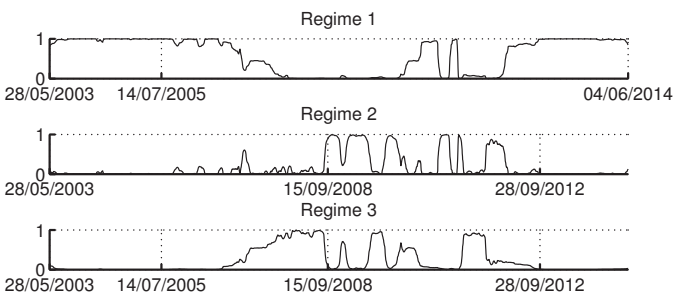

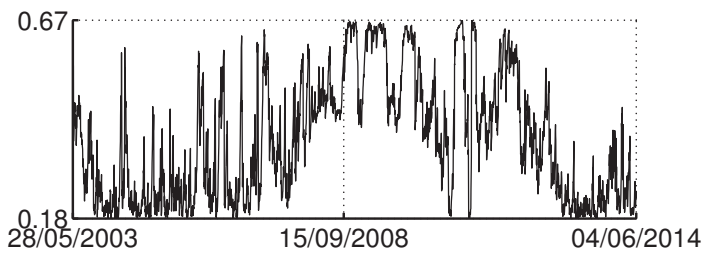

(b) Agriculture/WTI
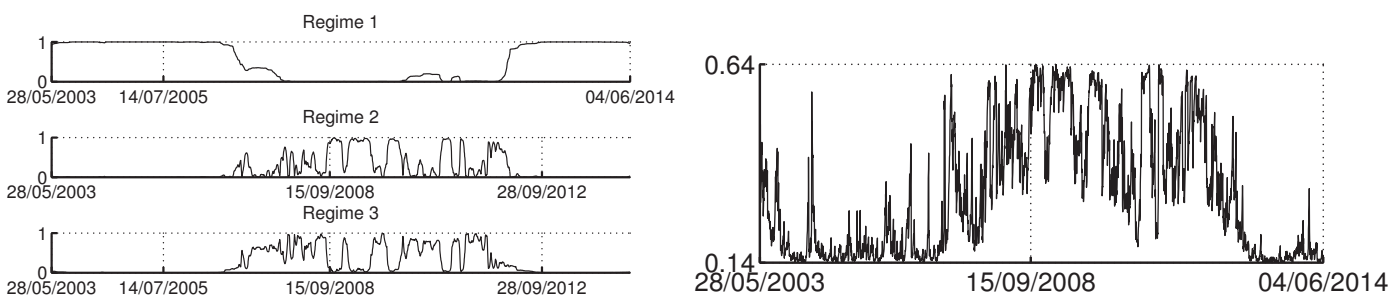

(c) Grains/WTI
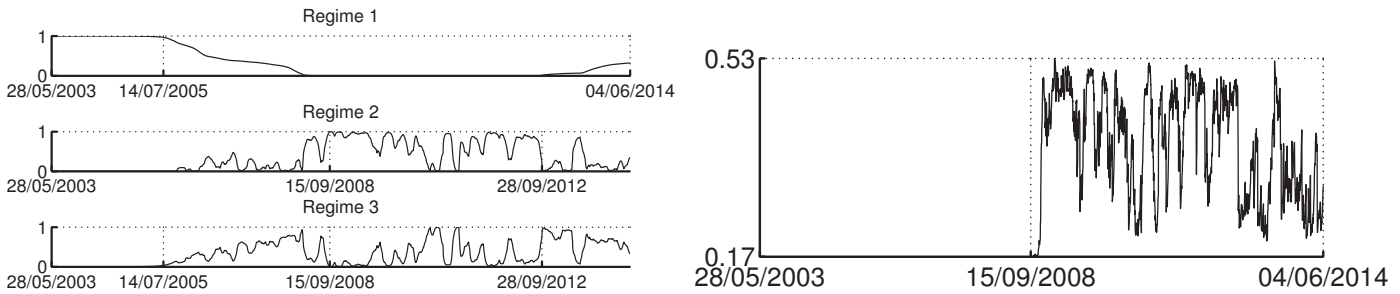

(d) Softs/WTI

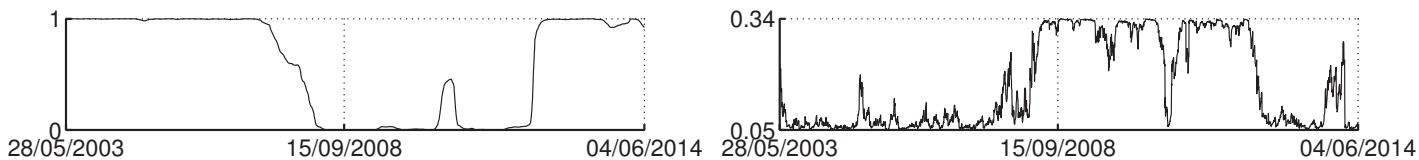

(e) Livestock/WTI

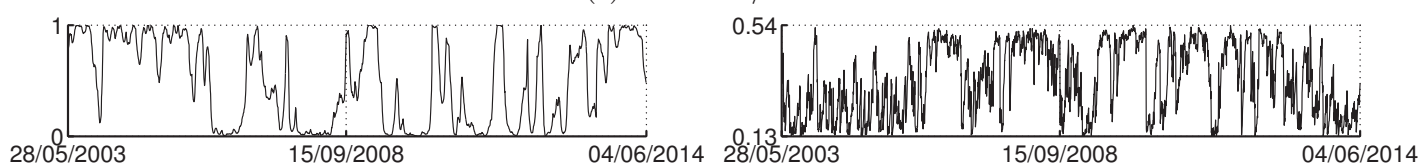

(f) Precious metals/WTI

Note: this figure plots the estimated smoothed probability (left) and dynamic correlation of indices returns, constructed from non-energy commodity futures groups (as defined in Section 3) and following GSCI weights (see Table 1 for futures weight details), with WTI (right), using daily data between May 28, 2003 and June 4, 2014. For instance, Panel (a) contains results from the constructed GSCI-weighted index from Industrial Metals futures returns. Results indicate three dynamic correlation switching regime, namely lower (regime One), higher (regime Two) and intermediate (regime Three) regimes. Only two regimes, lower (regime One) and higher (regime Two) regimes, are identified for Livestock and Precious Metals. 
Figure 13: GSCI sub-indices with WTI

Smoothed probability

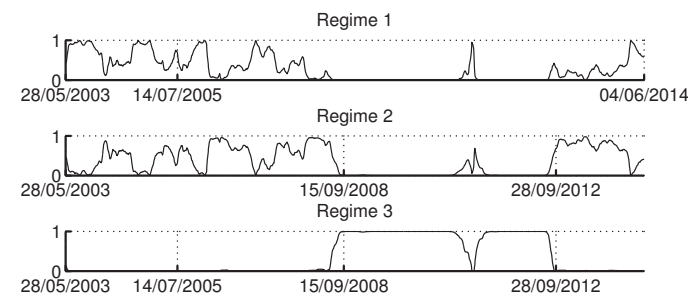

Estimated correlations

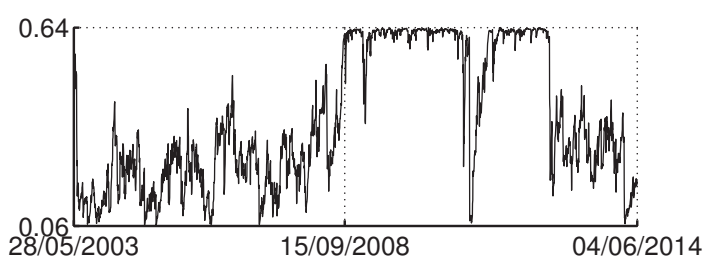

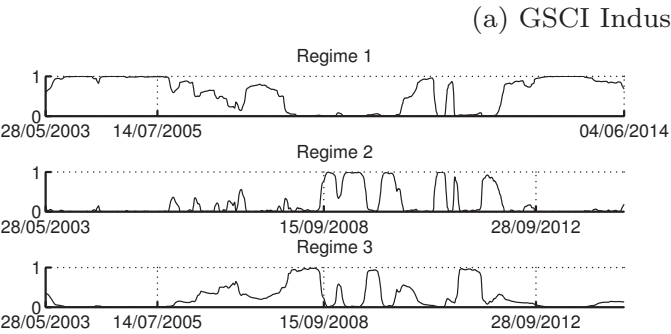

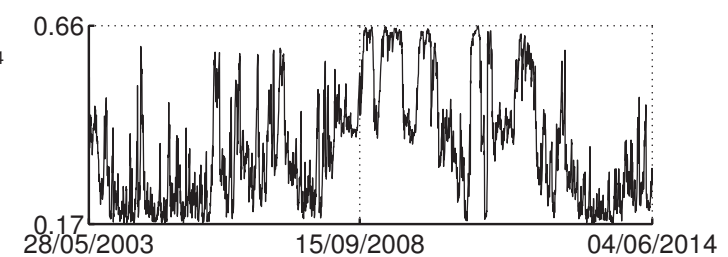

(b) GSCI Agriculture/WTI

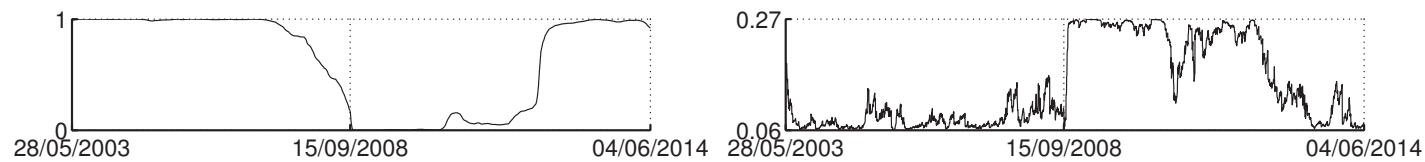

(c) GSCI Livestock Index/WTI

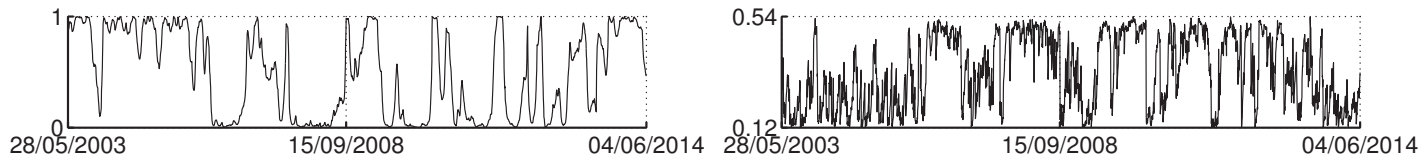

(d) GSCI Precious Metals Index/WTI

Note: this figure plots the estimated smoothed probability (left) and dynamic correlation of GSCI sub-indices, with WTI (right), using daily data between May 28, 2003 and June 4, 2014. For instance, Panel (a) contains results from GSCI Industrial Metals index. Results indicate three dynamic correlation switching regime, namely lower (regime One), higher (regime Two) and intermediate (regime Three) regimes. Only two regimes, lower (regime One) and higher (regime Two) regimes, are identified for Livestock and Precious Metals GSCI subindices. 

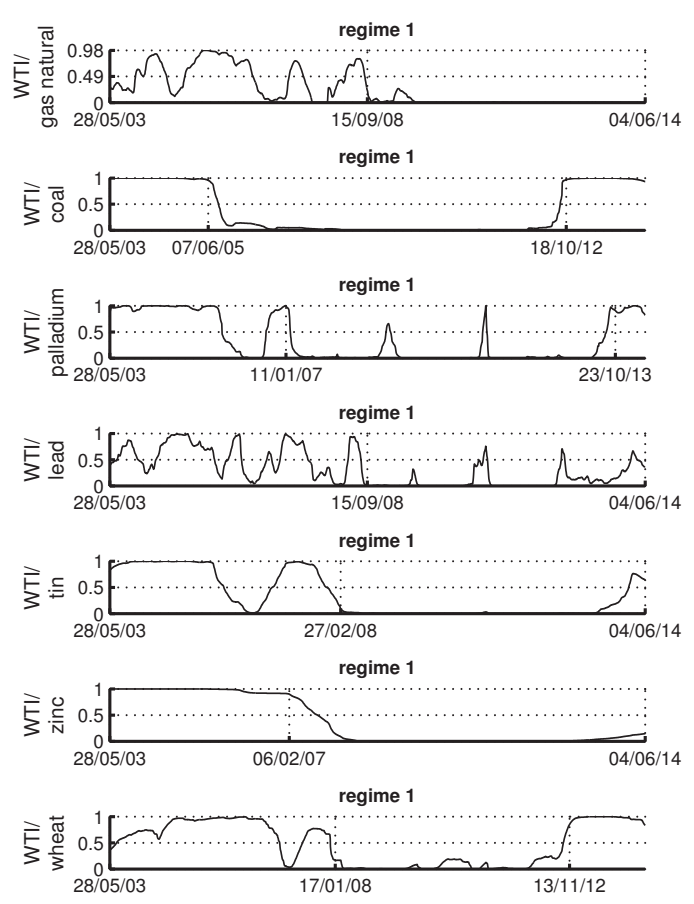

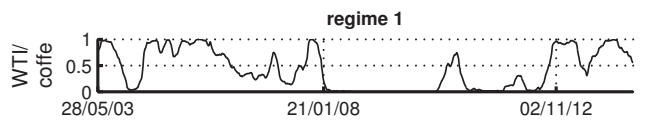
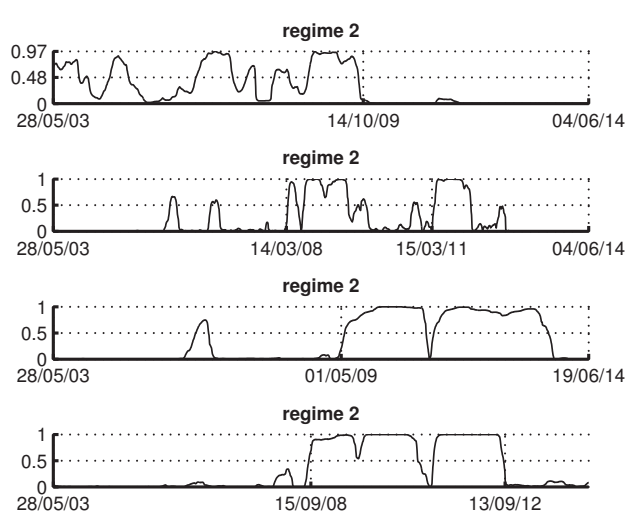

ת)

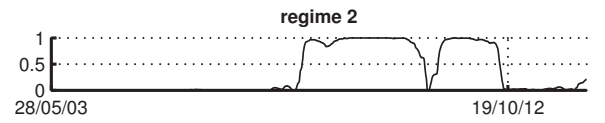

regime 2

$\underset{28 / 05 / 03}{0.5}$

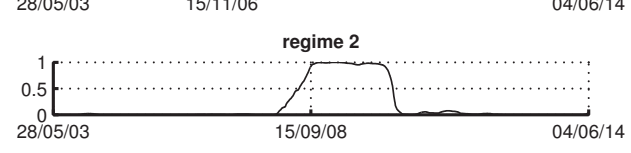

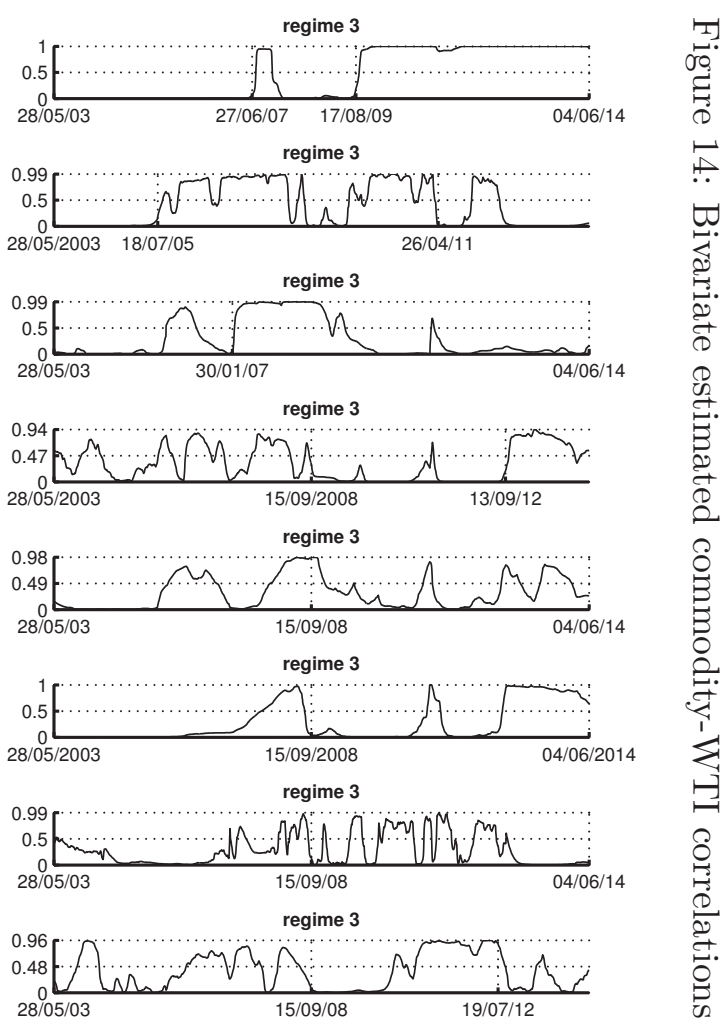



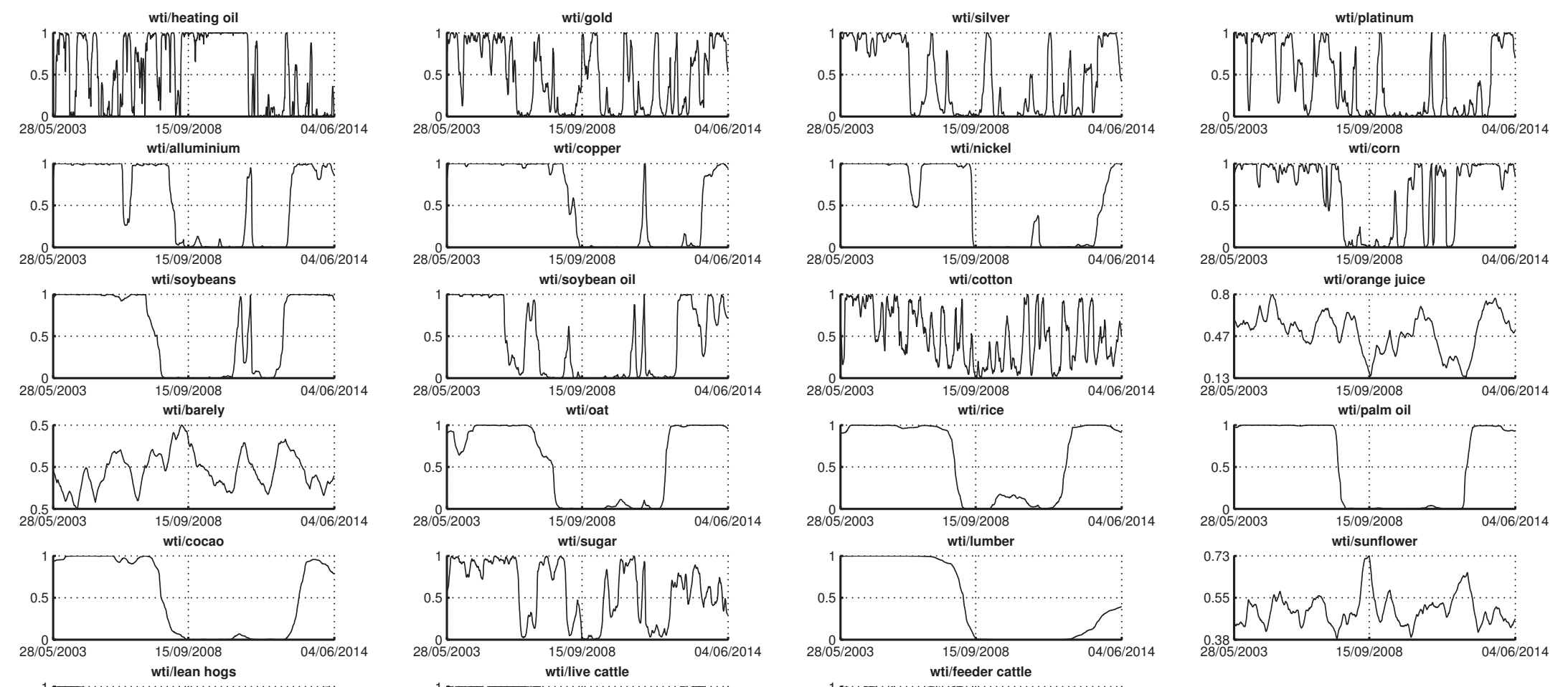

${ }_{2805 / 2003}^{0.55}$
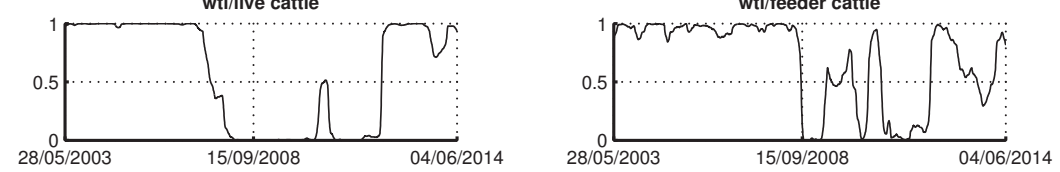


\section{Commodities with S\&P 500}

Figure 16: GSCI sub-indices with S\&P 500

Smoothed probability

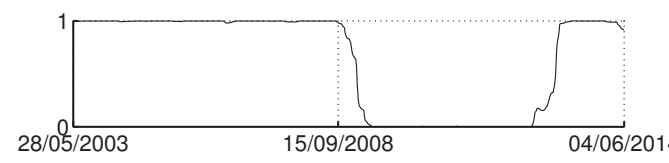

Estimated correlations

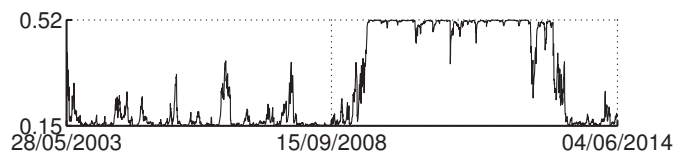

(a) GSCI Industrial metals/SP500

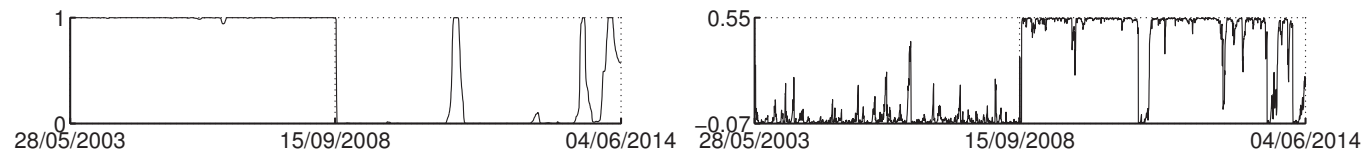

(b) GSCI Energy/SP500

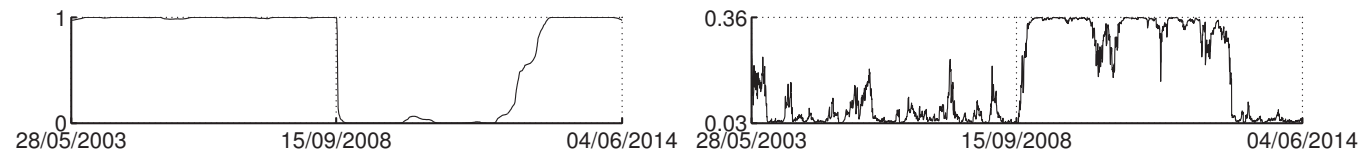

(c) GSCI Agriculture/SP500

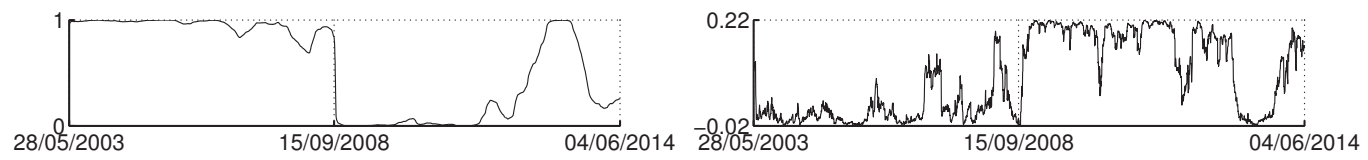

(d) GSCI Livestock/SP500

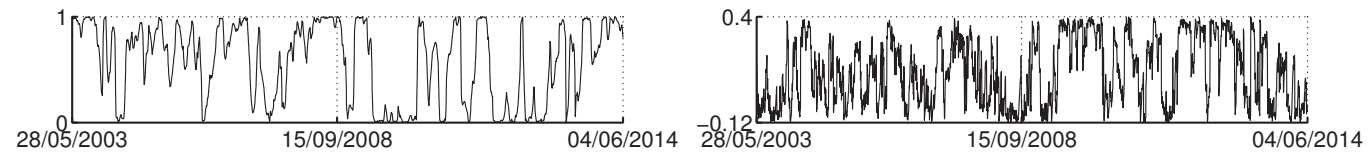

(e) GSCI Precious Metals/SP500

Note: this figure plots the estimated smoothed probability (left) and dynamic correlation of commodity indices returns with S\&P 500 (right), using daily data between May 28, 2003 and June 4, 2014.Panels (a)-(d) represent results for Industrial Metals, Energy, Agriculture, Livestock and Precious Metals GSCI sub-indices, respectively. The focus on the GSCI index is justified by its very high market share (63\%). Results indicate two dynamic correlation switching regime, regime One referring to the weaker correlation regime. 
Figure 17: Commodity groups following GSCI weights with S\&P 500

Smoothed probability

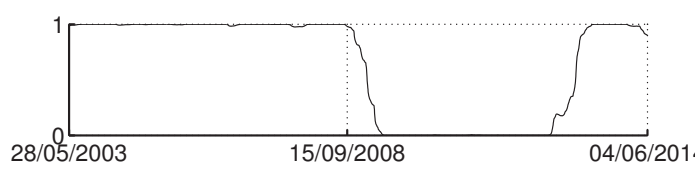

Estimated correlations

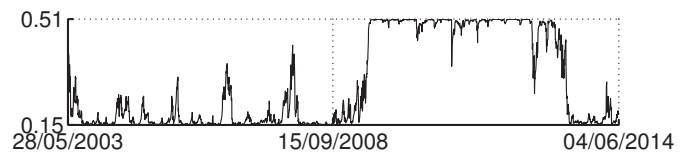

(a) Industrial metals/SP500

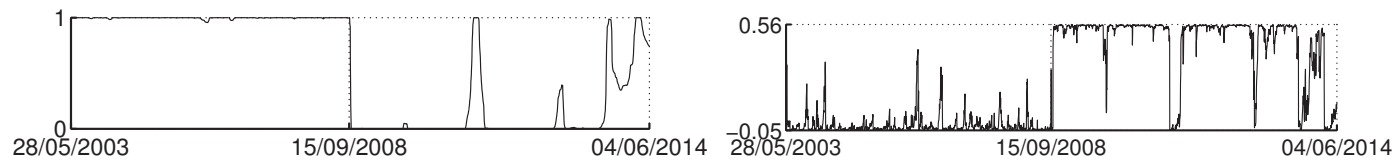

(b) Energy/SP500

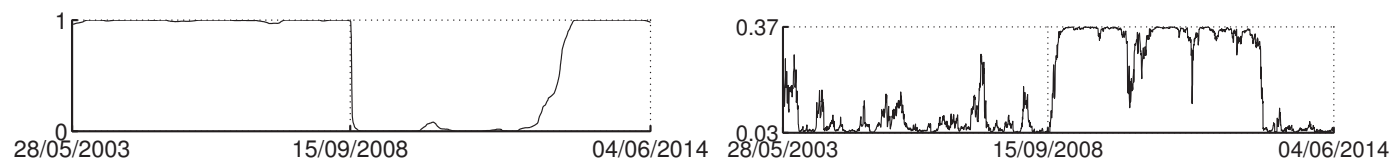

(c) Agriculture/SP500

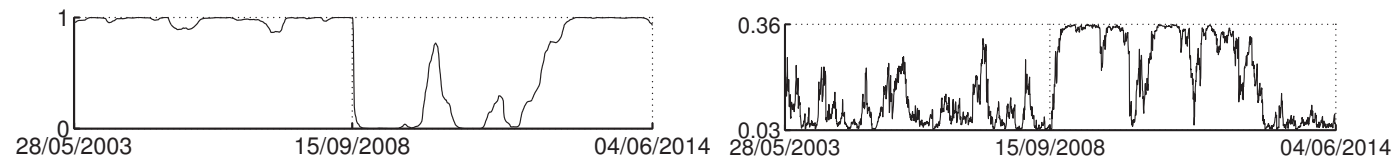

(d) Grains/SP500

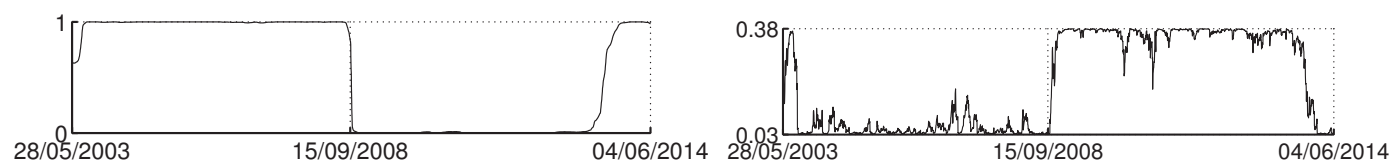

(e) Softs/SP500

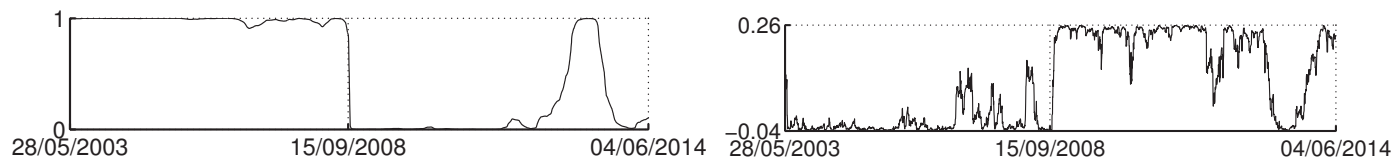

(f) Livestock/SP500

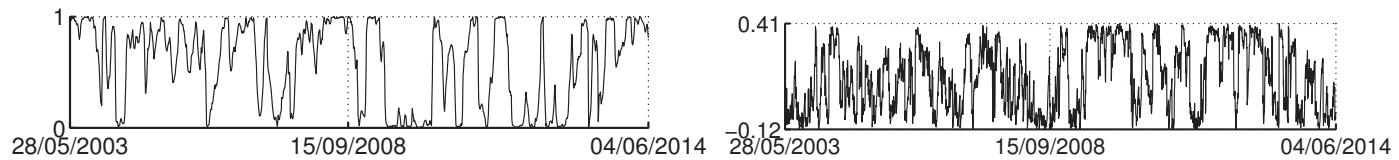

(g) Precious Metals/SP500

Note: this figure plots the estimated smoothed probability (left) and dynamic correlation of indices returns, constructed from non-energy commodity futures groups (as defined in Section 3) and following GSCI weights (see Table 4 for commodity futures weight details), with S\&P 500 (right), using daily data between May 28, 2003 and June 4, 2014. For instance, Panel (a) contains results from the GSCI-weighted index constructed from Industrial Metals futures returns. Results indicate two dynamic correlation switching regimes, regime One referring to the weaker correlation regime. 


\section{Commodities with Bonds}

Figure 18: GSCI sub-indices with US Bond

Smoothed probability

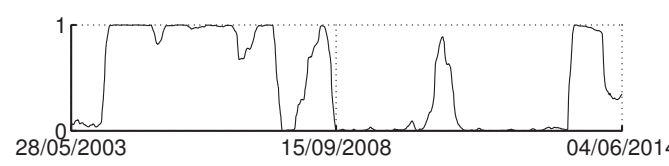

Estimated correlations

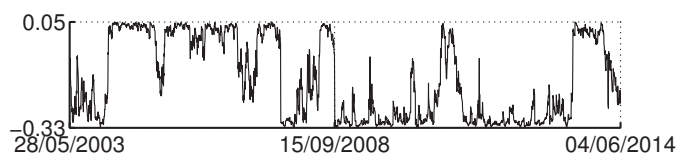

(a) GSCI Industrial metals/SP500
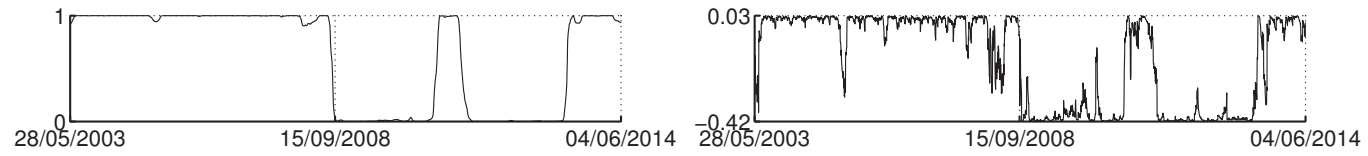

(b) GSCI Energy/SP500
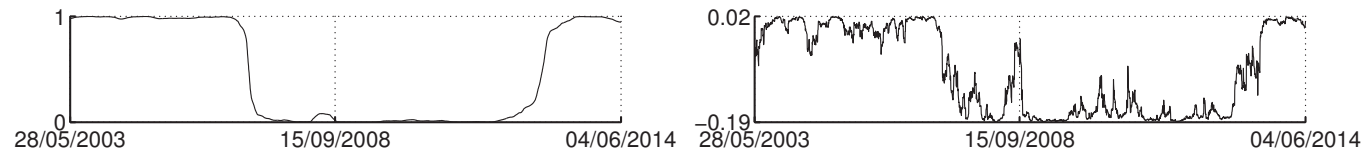

(c) GSCI Agriculture/SP500
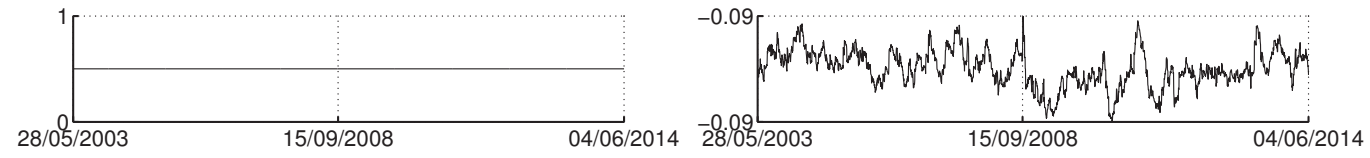

(d) GSCI Livestock/SP500
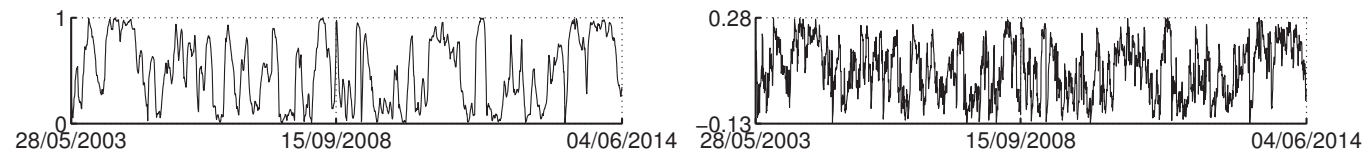

(e) GSCI Precious Metals/SP500

Note: this figure plots the estimated smoothed probability (left) and dynamic correlation of commodity indices returns with US Bonds (right), using daily data between May 28, 2003 and June 4, 2014. Results indicate two dynamic correlation switching regimes. While regime One refers to the weak, but positive, correlation regime, regime Two refers to a high and negative correlation regime. 
Figure 19: Commodity groups with US Bonds

Smoothed probability

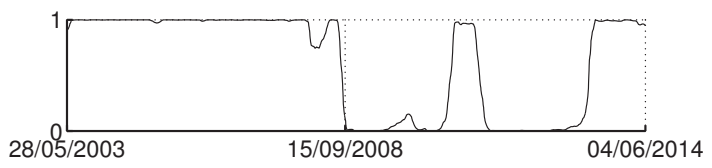

(a) Energy/US Bond
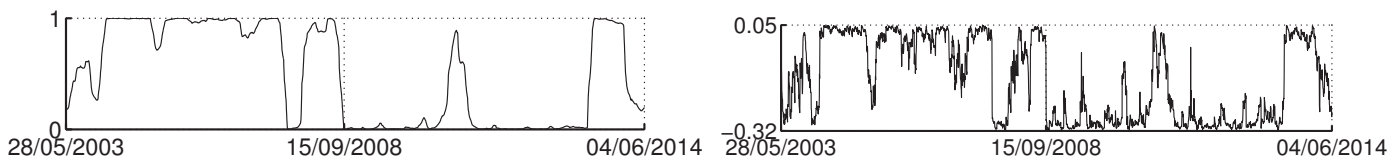

(b) Industrial metals/US Bonds
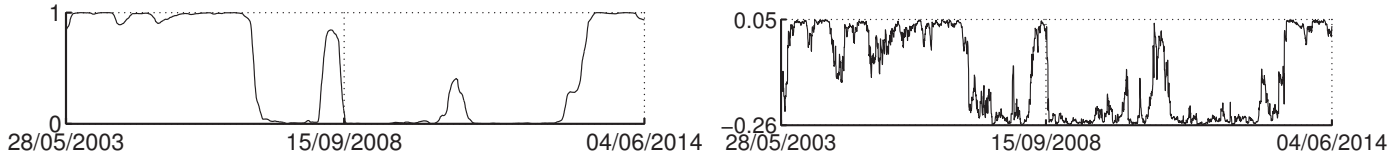

(c) Agriculture/US Bonds

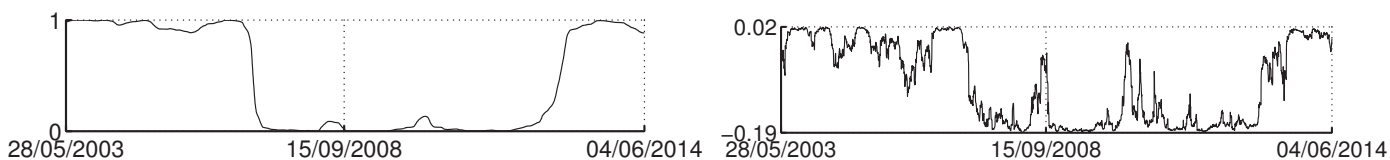

(d) Grains/US Bonds

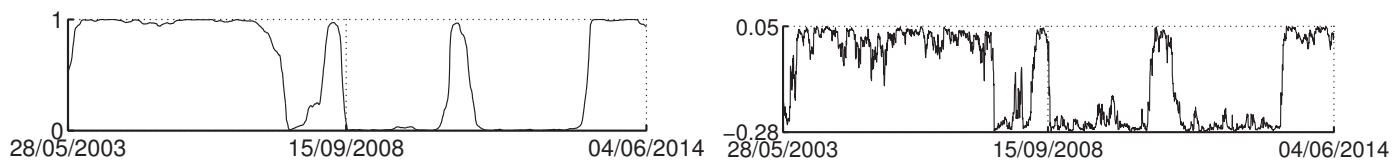

(e) Softs/US Bonds

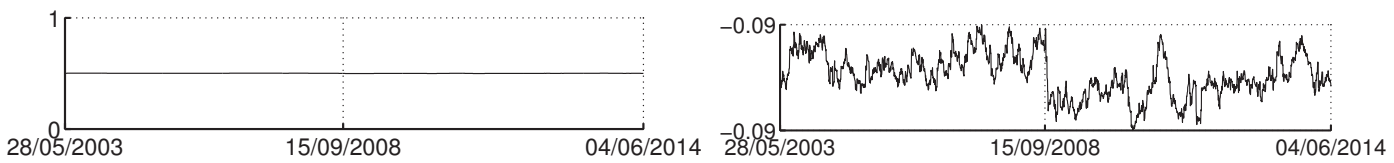

(f) Livestock/US Bonds

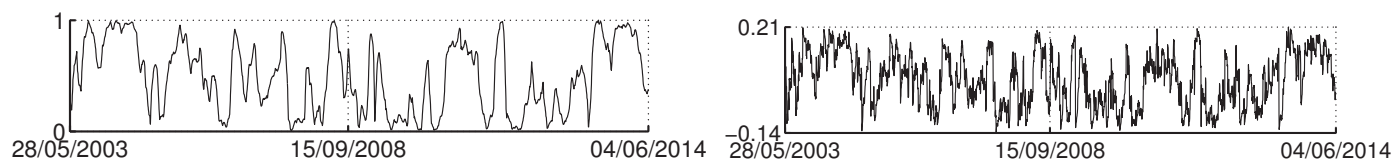

(g) Precious Metals/US Bonds

Note: this figure plots the estimated smoothed probability (left) and dynamic correlation of the equally-weighted indices returns, constructed from commodity futures groups (as defined in Section 3), with US Bond (right), using daily data between May 28, 2003 and June 4, 2014. For instance, Panel (a) contains results from the equally-weighted index constructed from Industrial Metals commodity futures returns. Results from panels (a)-(e) indicate two dynamic correlation switching regimes; regime One referring to the weak, but positive correlation regime and regime Two referring to the highly negative regime. Panels (f) and (g) have different patterns without a regime change. 
Figure 20: Commodity GSCI groups with US Bonds

\section{Smoothed probability}

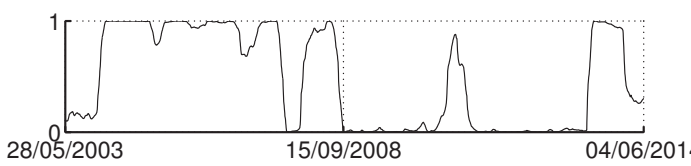

Estimated correlations

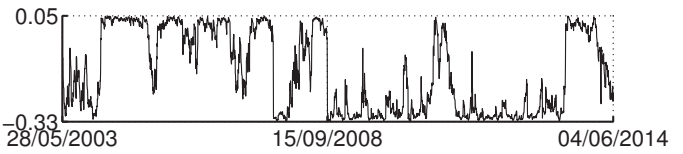

(a) Indutrial metals/US Bonds

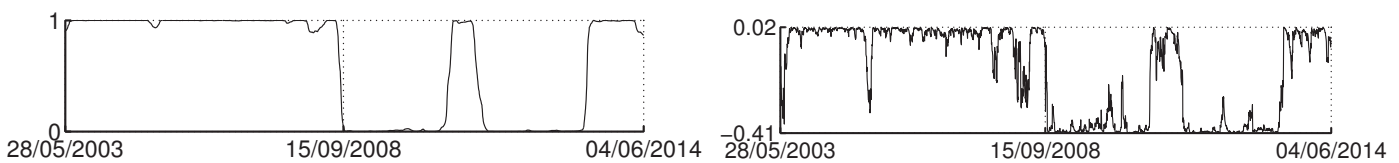

(b) Energy/US Bonds
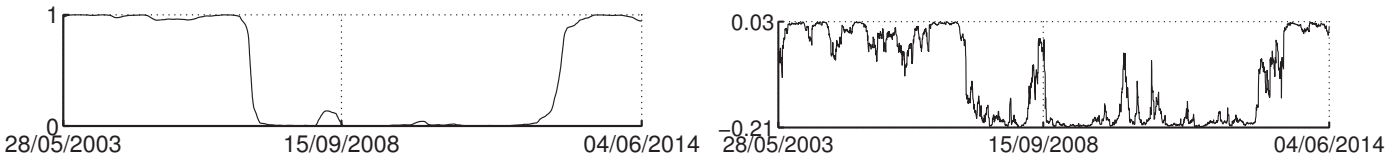

(c) Agriculture/US Bonds
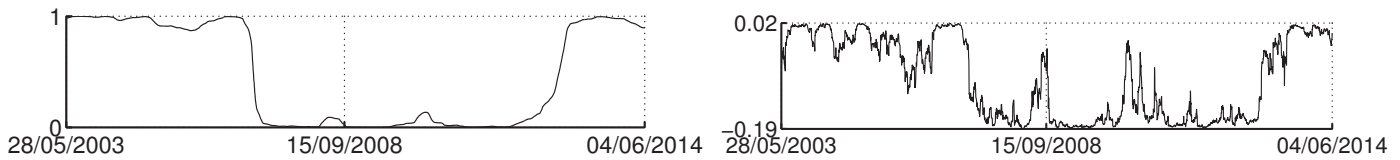

(d) Grain/US Bonds

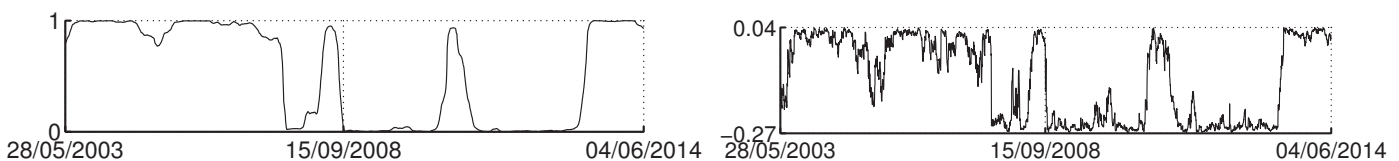

(e) Softs/US Bonds

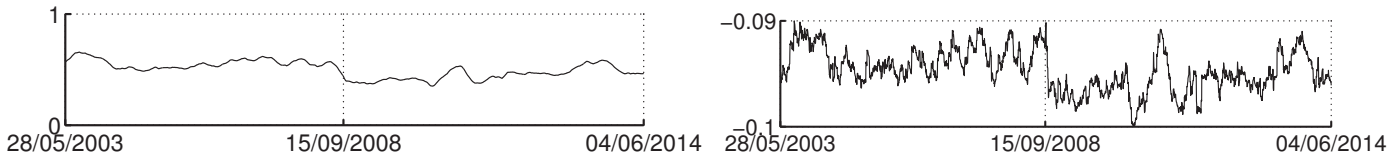

(f) Livestock/US Bonds

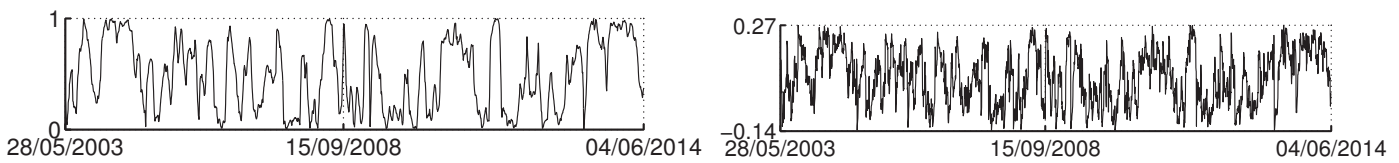

(g) Precious Metals/US Bonds

Note: this figure plots the estimated smoothed probability (left) and dynamic correlation of constructed group indices using GSCI weights, with US Bond (right), using daily data between May 28, 2003 and June 4, 2014. For instance, Panel (a) contains results from the GSCI-weighted index constructed from Industrial Metals commodity futures returns. Results from panels (a)-(e) indicate two dynamic correlation switching regime; regime One referring to the weak, but positive correlation regime and regime Two referring to the highly negative regime. Panels (f) and (g) have different patterns without a regime change. 
Supplementary Appendix :

Commodity returns co-movements: Fundamentals or "style "effect? 

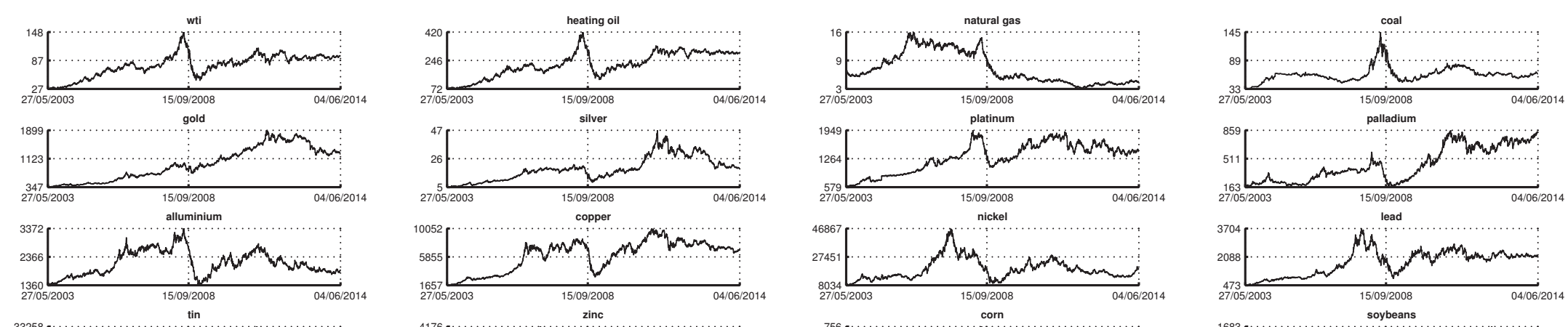

${ }_{27705 / 2003}^{10052}$
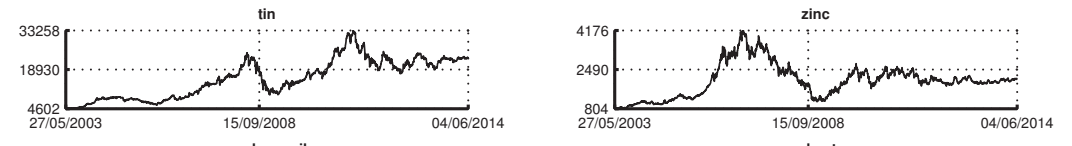

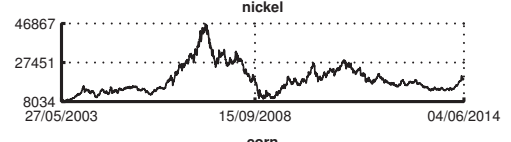

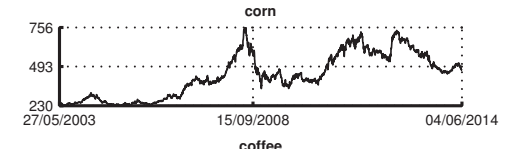

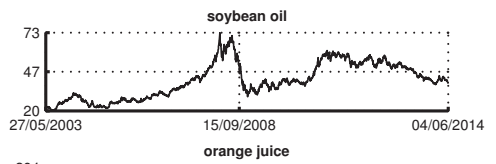

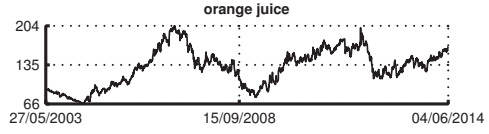

barley

251/06/2014
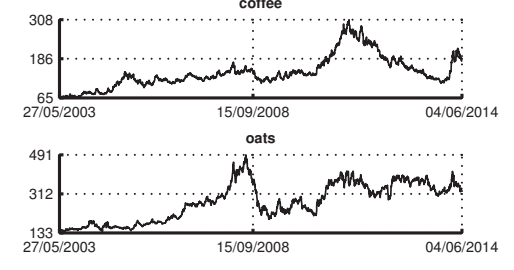

2725

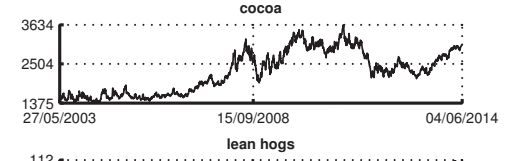

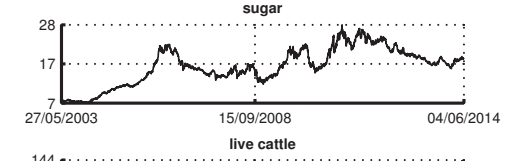

suntlowers
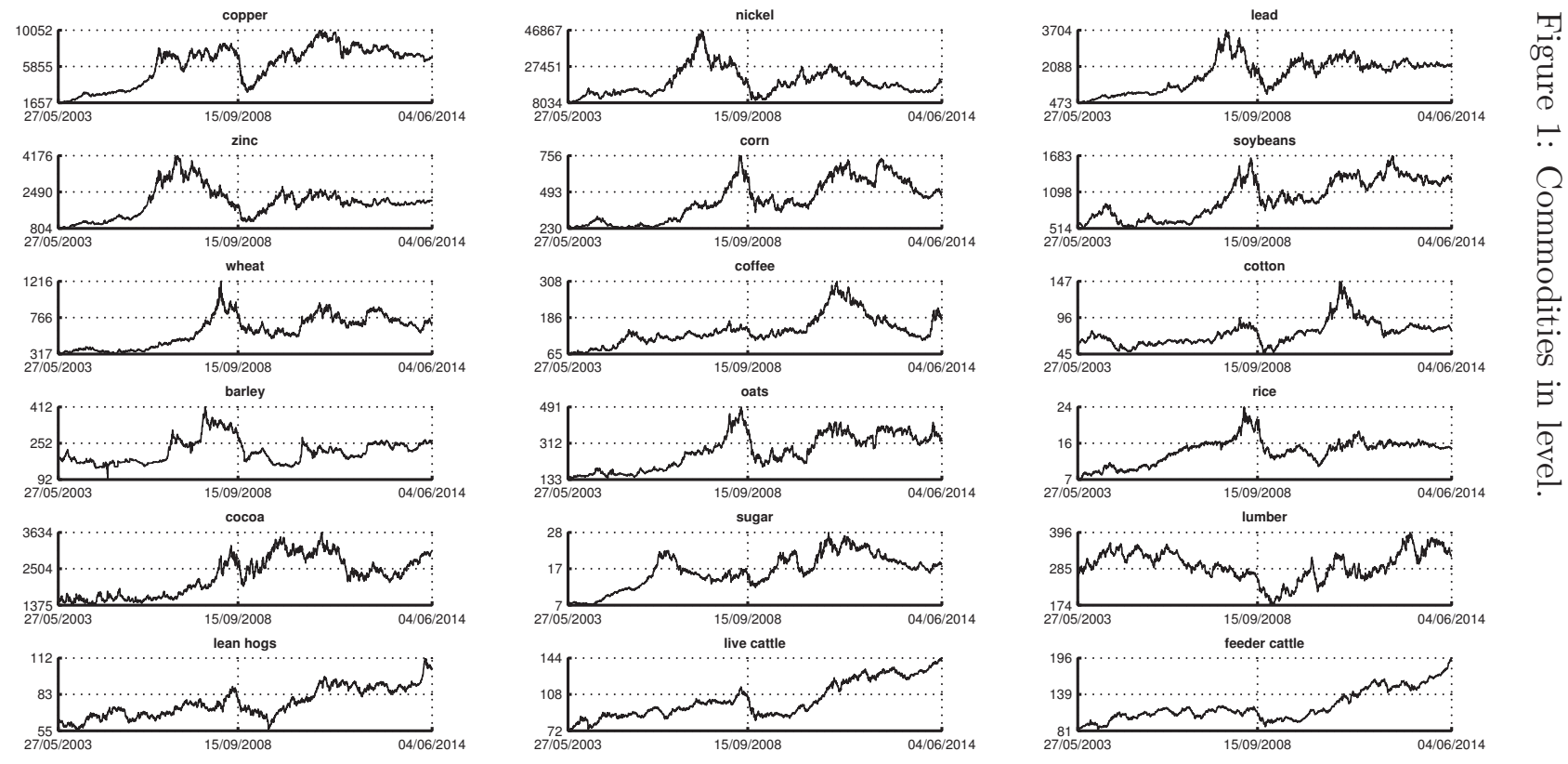

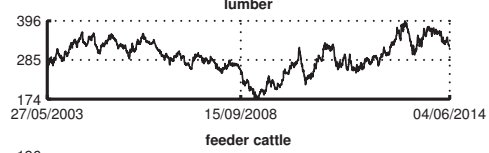

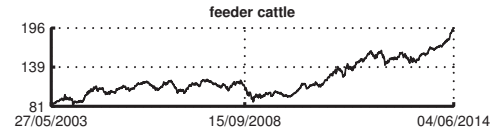



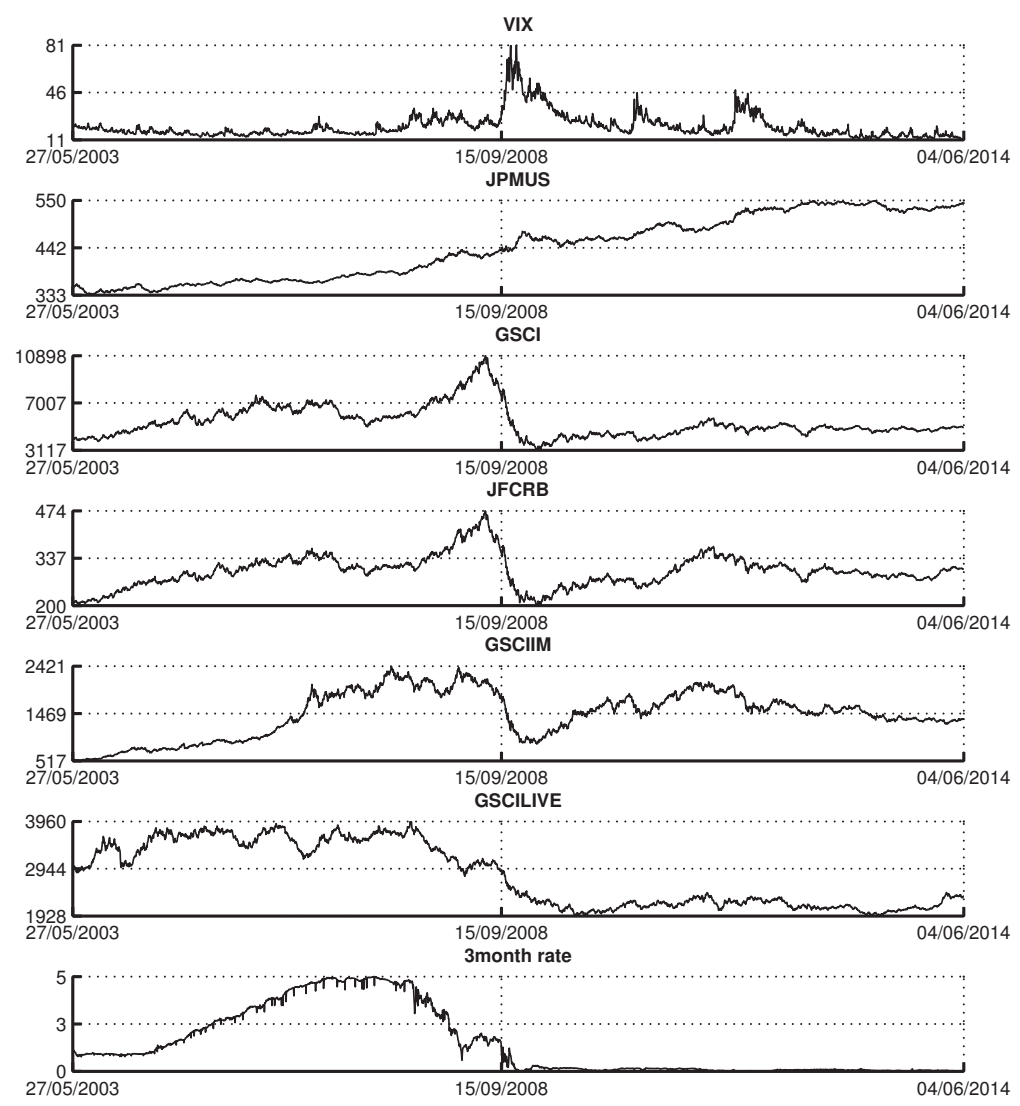
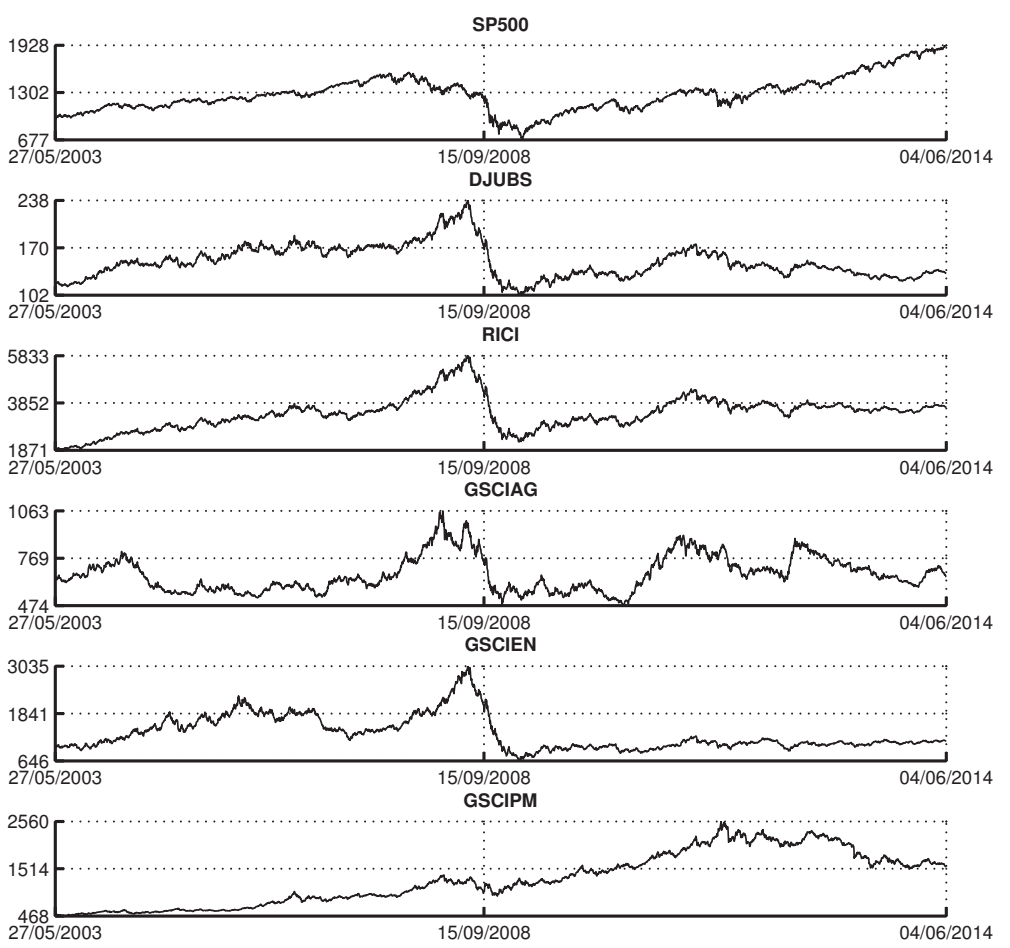

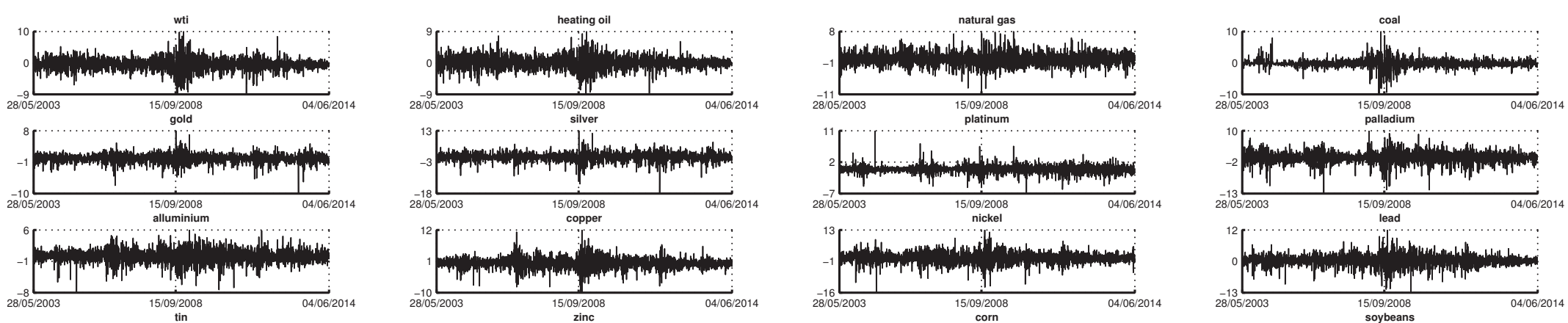

${ }_{28}^{-1305 / 2003}$

范

$\left.{ }_{-1105 / 2003}^{14}\right|_{15 / 09 / 2008} ^{14}$
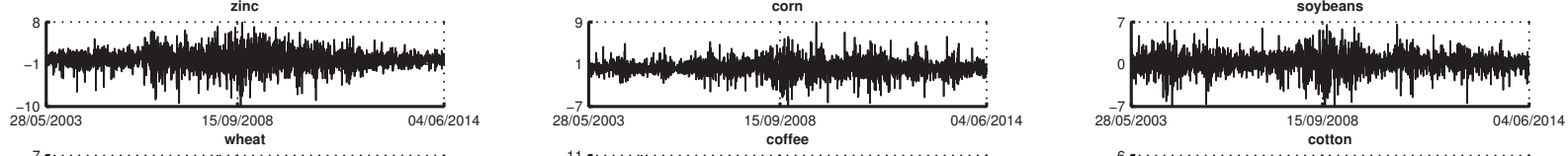

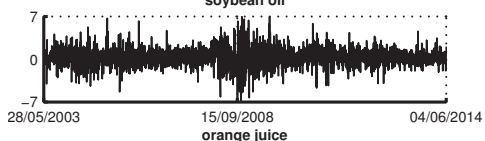

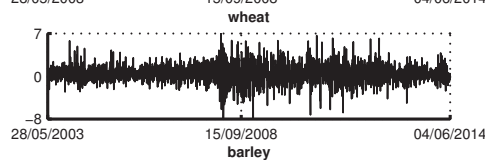

040612014
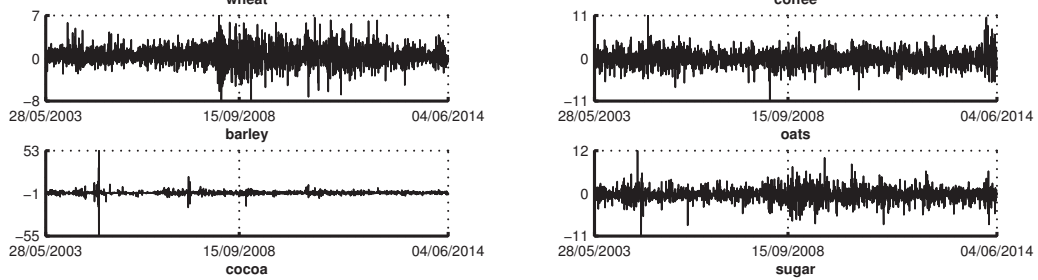

$\int_{-8}^{6} \int_{-805 / 2003}^{6}$

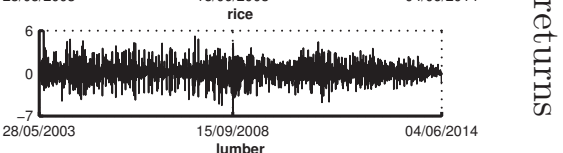
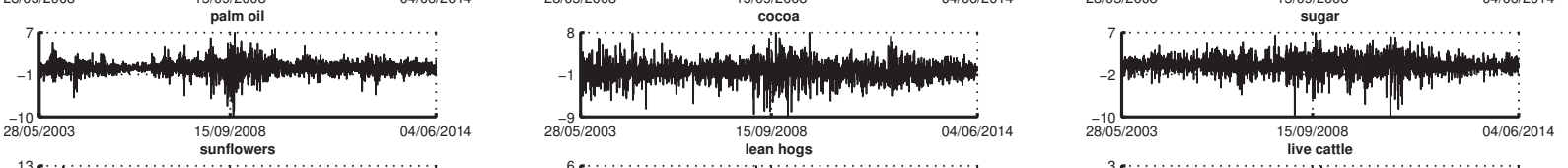

${ }_{28}^{2} \int_{052 / 2003}^{13}$
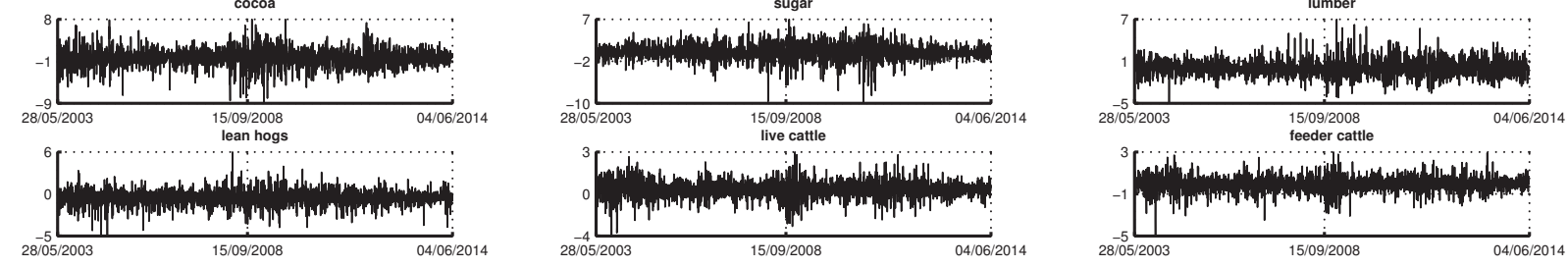

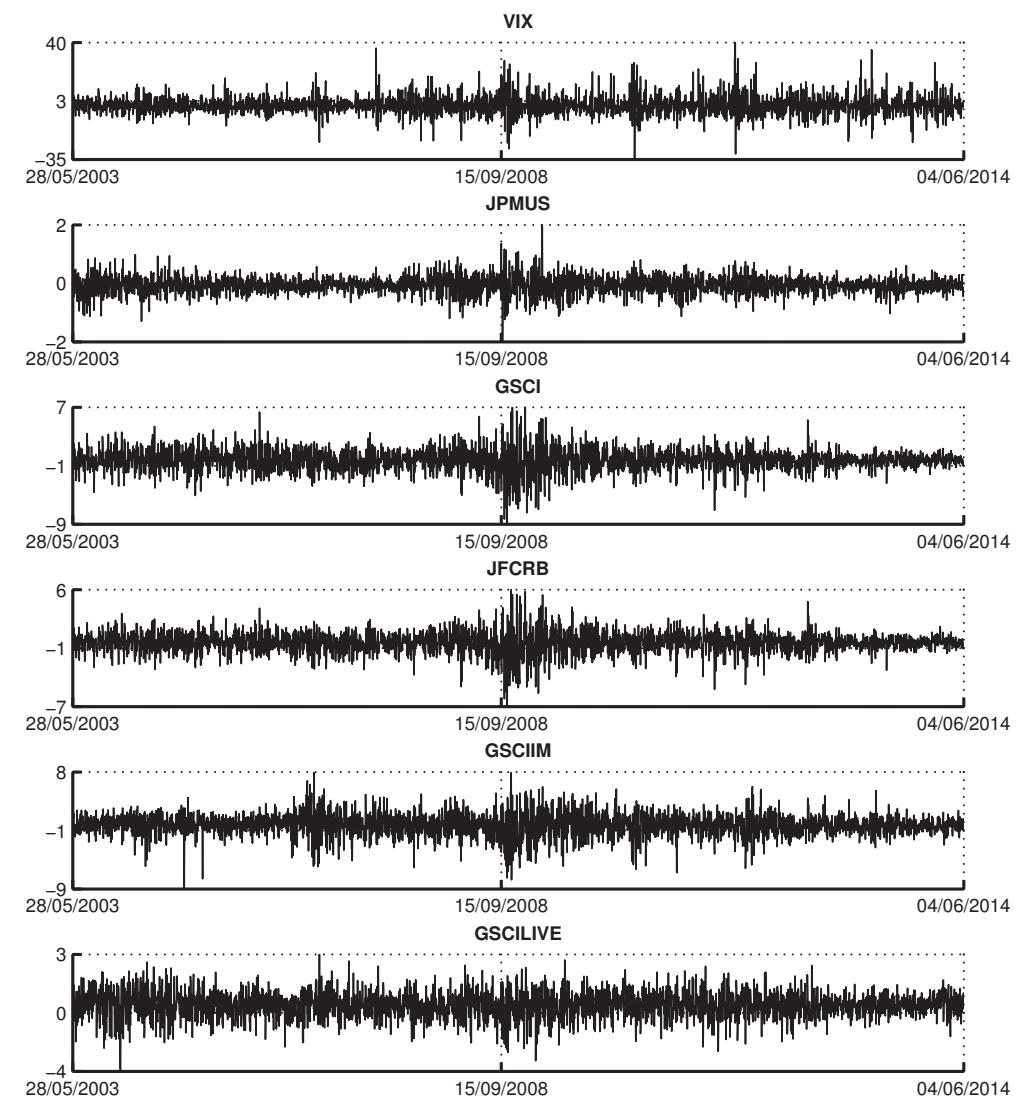
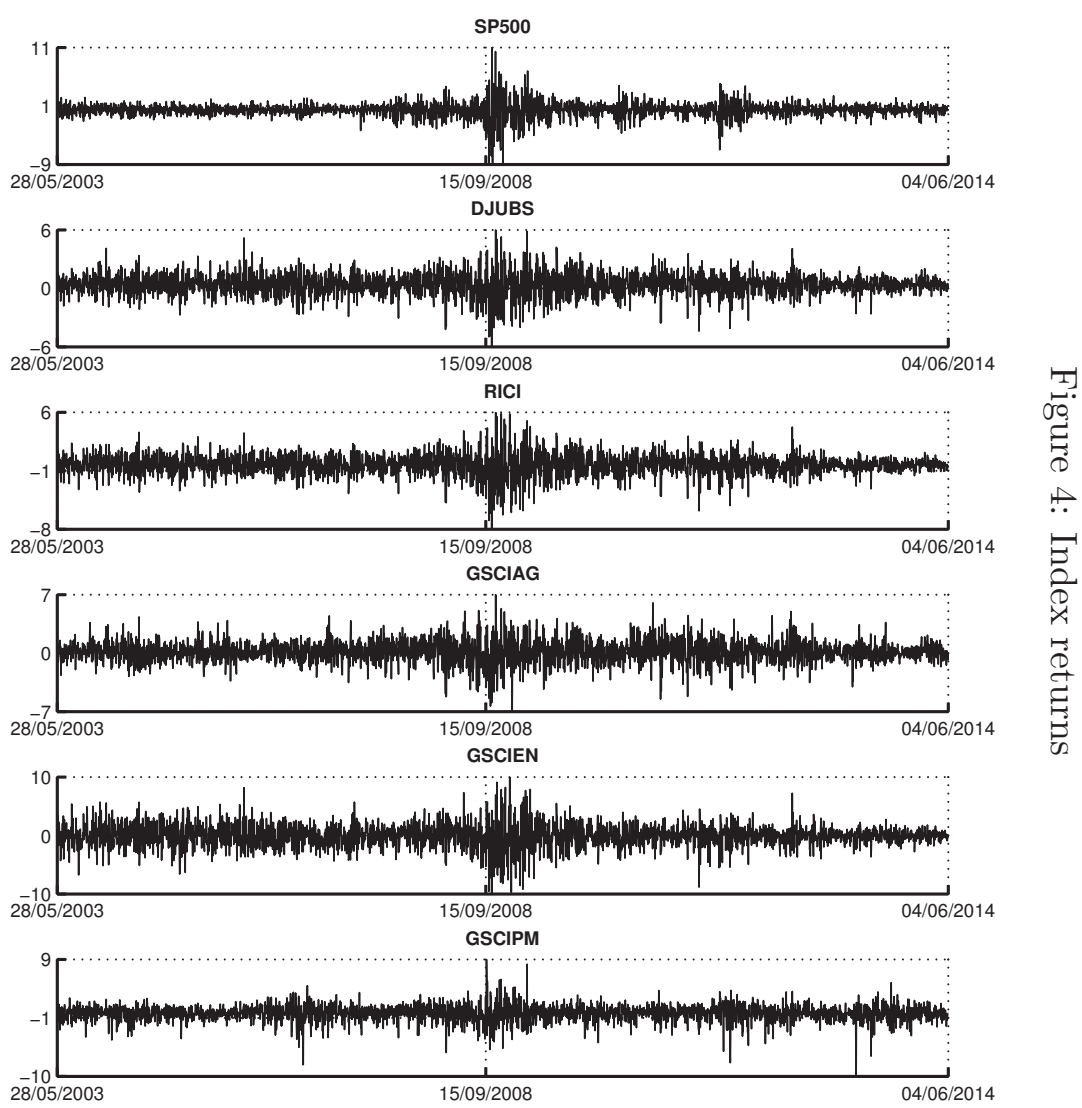


\section{De-garching}

Table 1 contains the selected model and estimated parameters for the 32 series of commodities, commodity (sub-) indices and traditional assets. Figures 5 and 6 , in the supplementary Appendix, show the estimated volatilities for commodities and the indices, respectively.

Table 1: Degarching for commodities

\begin{tabular}{|c|c|c|c|c|c|c|c|}
\hline Series & Model selected & $\omega$ & $\alpha$ & $\beta$ & $\gamma$ & $p_{11}$ & $p_{22}$ \\
\hline wti & EGARCH & $\begin{array}{c}8.4064 e-03 \\
(1.6516 e-05)\end{array}$ & $\begin{array}{c}0.1032 \\
(3.5254 e-04)\end{array}$ & $\begin{array}{c}-0.0396 \\
(1.2995 e-04)\end{array}$ & $\begin{array}{c}0.9936 \\
(1.1606 e-05)\end{array}$ & & \\
\hline heating oil & GARCH & $\begin{array}{c}2.2489 e-03 \\
(1.0144 e-05)\end{array}$ & $\begin{array}{c}0.0300 \\
(3.0869 e-05)\end{array}$ & $\begin{array}{c}0.9695 \\
(3.2210 e-05)\end{array}$ & & & \\
\hline natural gas & NAGARCH & $\begin{array}{c}8.2984 e-02 \\
(8.9677 e-04)\end{array}$ & $\begin{array}{c}0.0487 \\
(1.3547 e-04)\end{array}$ & $\begin{array}{c}0.4625 \\
(2.5321 e-02)\end{array}$ & $\begin{array}{c}0.9160 \\
(3.9181 e-04)\end{array}$ & & \\
\hline \multirow[t]{2}{*}{ coal } & MS-GARCH & $\begin{array}{c}1.5373 e-02 \\
(2.4583 e-04)\end{array}$ & $\begin{array}{c}0.0671 \\
(6.4581 e-04)\end{array}$ & $\begin{array}{c}0.8223 \\
(5.5234 e-03)\end{array}$ & & $\begin{array}{c}0.9809 \\
(1.9091 e-03)\end{array}$ & $\begin{array}{c}0.9999 \\
(2.0231 e-08)\end{array}$ \\
\hline & & $\begin{array}{c}1.7292 e-02 \\
(2.9865 e-04)\end{array}$ & $\begin{array}{c}0.0738 \\
(7.0805 e-04)\end{array}$ & $\begin{array}{c}0.9132 \\
(1.6568 e-03)\end{array}$ & & & \\
\hline \multirow[t]{2}{*}{ gold } & MS-GARCH & $\begin{array}{c}1.0000 e+00 \\
(7.5302 e-01)\end{array}$ & $\begin{array}{c}0.4246 \\
(8.6224 e-02)\end{array}$ & $\begin{array}{c}0.3783 \\
(1.0626 e-01)\end{array}$ & & $\begin{array}{c}0.9338 \\
(3.9328 e-04)\end{array}$ & $\begin{array}{c}0.9996 \\
(1.0324 e-07)\end{array}$ \\
\hline & & $\begin{array}{c}1.0399 e-02 \\
(6.9514 e-05)\end{array}$ & $\begin{array}{c}0.0277 \\
(6.9306 e-05)\end{array}$ & $\begin{array}{c}0.9623 \\
(2.6454 e-04)\end{array}$ & & & \\
\hline silver & FIGARCH & $\begin{array}{c}5.6105 e-01 \\
(5.4388 e-02)\end{array}$ & $\begin{array}{c}0.3544 \\
(6.2063 e-02)\end{array}$ & $\begin{array}{c}0.2913 \\
(1.5297 e-02)\end{array}$ & $\begin{array}{c}0.4915 \\
(1.2340 e-01)\end{array}$ & & \\
\hline \multirow[t]{2}{*}{ platinum } & MS-GARCH & $\underset{(6.8153 e-03)}{2.6174 e-01}$ & $\begin{array}{c}0.0792 \\
(1.7758 e-04)\end{array}$ & $\begin{array}{c}0.8097 \\
(2.0322 e-03)\end{array}$ & & $\begin{array}{c}0.9821 \\
(2.5719 e-05)\end{array}$ & $\begin{array}{c}0.9839 \\
(4.4406 e-05)\end{array}$ \\
\hline & & $\begin{array}{c}5.3263 e-03 \\
(7.2956 e-06)\end{array}$ & $\begin{array}{c}0.0059 \\
(5.0943 e-06)\end{array}$ & $\begin{array}{c}0.9841 \\
(4.0586 e-05)\end{array}$ & & & \\
\hline palladium & GARCH & $\begin{array}{c}4.8302 e-02 \\
(5.8382 e-04)\end{array}$ & $\begin{array}{c}0.0680 \\
(1.7898 e-04)\end{array}$ & $\begin{array}{c}0.9219 \\
(2.5100 e-04)\end{array}$ & & & \\
\hline \multirow[t]{2}{*}{ aluminum } & MS-GARCH & $\begin{array}{c}1.5134 e-02 \\
(3.9242 e-04)\end{array}$ & $\begin{array}{c}0.0989 \\
(8.2680 e-04)\end{array}$ & $\begin{array}{c}0.8911 \\
(1.0080 e-03)\end{array}$ & & $\begin{array}{c}0.9820 \\
(2.3364 e-04)\end{array}$ & $\begin{array}{c}0.9962 \\
(1.1890 e-05)\end{array}$ \\
\hline & & $\begin{array}{c}1.6467 e-02 \\
(9.5962 e-05)\end{array}$ & $\begin{array}{c}0.0175 \\
(4.8047 e-05)\end{array}$ & $\begin{array}{c}0.9725 \\
(1.4812 e-04)\end{array}$ & & & \\
\hline copper & GARCH & $\underset{(1.2503 e-04)}{2.4117 e-02}$ & $\begin{array}{c}0.0500 \\
(1.3531 e-04)\end{array}$ & $\begin{array}{c}0.9425 \\
(1.8726 e-04)\end{array}$ & & & \\
\hline nickel & GARCH & $\begin{array}{c}5.7550 e-02 \\
(7.7787 e-04)\end{array}$ & $\begin{array}{c}0.0642 \\
(2.6433 e-04)\end{array}$ & $\begin{array}{c}0.9268 \\
(3.5126 e-04)\end{array}$ & & & \\
\hline lead & GARCH & $\begin{array}{c}1.7488 e-02 \\
(1.2655 e-04)\end{array}$ & $\begin{array}{c}0.0451 \\
(2.0083 e-04)\end{array}$ & $\begin{array}{c}0.9520 \\
(2.3080 e-04)\end{array}$ & & & \\
\hline $\operatorname{tin}$ & FIGARCH & $\begin{array}{c}5.5677 e-01 \\
(2.4280 e-02)\end{array}$ & $\begin{array}{c}0.3697 \\
(6.2474 e-02)\end{array}$ & $\begin{array}{c}0.2606 \\
(2.9528 e-03)\end{array}$ & $\begin{array}{c}0.4694 \\
(7.5449 e-02)\end{array}$ & & \\
\hline zinc & GARCH & $\begin{array}{c}7.4981 e-03 \\
(4.8006 e-05)\end{array}$ & $\begin{array}{c}0.0369 \\
(2.2202 e-04)\end{array}$ & $\begin{array}{c}0.9617 \\
(2.4630 e-04)\end{array}$ & & & \\
\hline \multirow[t]{2}{*}{ corn } & MS-GARCH & $\begin{array}{c}3.8774 e-02 \\
(4.9616 e-04)\end{array}$ & $\begin{array}{c}0.0378 \\
(4.3713 e-05)\end{array}$ & $\begin{array}{c}0.9522 \\
(1.0901 e-04)\end{array}$ & & $\begin{array}{c}0.9728 \\
(5.3858 e-05)\end{array}$ & $\begin{array}{c}0.9488 \\
(4.4515 e-04)\end{array}$ \\
\hline & & $\begin{array}{c}3.3268 e-03 \\
(3.1743 e-06)\end{array}$ & $\begin{array}{c}0.0082 \\
(4.8502 e-06)\end{array}$ & $\begin{array}{c}0.9818 \\
(2.5906 e-05)\end{array}$ & & & \\
\hline \multirow[t]{2}{*}{ soybeans } & MS-GARCH & $\begin{array}{c}1.5590 e-02 \\
(7.2944 e-05)\end{array}$ & $\begin{array}{c}0.0187 \\
(1.4564 e-04)\end{array}$ & $\begin{array}{c}0.9681 \\
(3.7662 e-04)\end{array}$ & & $\begin{array}{c}0.9844 \\
(9.0032 e-05)\end{array}$ & $\begin{array}{c}0.9833 \\
(6.3892 e-04)\end{array}$ \\
\hline & & $\begin{array}{c}3.9673 e-02 \\
(8.3221 e-03)\end{array}$ & $\begin{array}{c}0.0539 \\
(1.6306 e-03)\end{array}$ & $\begin{array}{c}0.9361 \\
(8.9860 e-04)\end{array}$ & & & \\
\hline \multirow[t]{2}{*}{ soybean oil } & MS-GARCH & $\begin{array}{c}8.4262 e-06 \\
(1.9858 e-03)\end{array}$ & $\begin{array}{c}0.1085 \\
(6.4373 e-03)\end{array}$ & $\begin{array}{c}0.8815 \\
(7.6789 e-03)\end{array}$ & & $\begin{array}{c}0.3640 \\
(3.1648 e-01)\end{array}$ & $\begin{array}{c}0.5215 \\
(2.9838 e+00)\end{array}$ \\
\hline & & $\begin{array}{c}2.0608 e-02 \\
(1.8391 e-02)\end{array}$ & $\begin{array}{c}0.0197 \\
(5.8826 e-03)\end{array}$ & $\begin{array}{c}0.9703 \\
(2.2073 e-02)\end{array}$ & & & \\
\hline \multirow[t]{2}{*}{ wheat } & MS-GARCH & $\begin{array}{c}1.1909 e-03 \\
(1.0124 e-06)\end{array}$ & $\begin{array}{c}0.0342 \\
(1.0277 e-04)\end{array}$ & $\begin{array}{c}0.9558 \\
(2.8648 e-04)\end{array}$ & & $\begin{array}{c}0.8068 \\
(1.4761 e-02)\end{array}$ & $\begin{array}{c}0.0001 \\
(1.0165 e-04)\end{array}$ \\
\hline & & $\begin{array}{c}4.2417 e-01 \\
(1.3920 e-02)\end{array}$ & $\begin{array}{c}0.1350 \\
(1.7554 e-03)\end{array}$ & $\begin{array}{c}0.8375 \\
(1.6084 e-03)\end{array}$ & & & \\
\hline coffee & NAGARCH & $\begin{array}{c}5.9194 e-02 \\
(4.3068 e-04)\end{array}$ & $\begin{array}{c}0.0271 \\
(4.5386 e-05)\end{array}$ & $\begin{array}{c}-0.8577 \\
(7.2337 e-02)\end{array}$ & $\begin{array}{c}0.9349 \\
(3.2364 e-04)\end{array}$ & & \\
\hline \multirow[t]{2}{*}{ cotton } & MS-GARCH & $\begin{array}{c}4.9824 e-03 \\
(2.5800 e-05)\end{array}$ & $\begin{array}{c}0.0147 \\
(2.9347 e-05)\end{array}$ & $\begin{array}{c}0.9753 \\
(1.1888 e-04)\end{array}$ & & $\begin{array}{c}0.9880 \\
(3.5147 e-05)\end{array}$ & $\begin{array}{c}0.9927 \\
(5.3855 e-06)\end{array}$ \\
\hline & & $\begin{array}{c}3.2894 e-02 \\
(2.5135 e-04)\end{array}$ & $\begin{array}{c}0.0632 \\
(3.1997 e-04)\end{array}$ & $\begin{array}{c}0.9255 \\
(5.0982 e-04)\end{array}$ & & & \\
\hline orange juice & FIGARCH & $\begin{array}{c}5.3606 e-01 \\
(1.1514 e-02)\end{array}$ & $\begin{array}{c}0.3896 \\
(5.5193 e-02)\end{array}$ & $\begin{array}{c}0.2207 \\
(1.3401 e-03)\end{array}$ & $\begin{array}{c}0.4525 \\
(5.9961 e-02)\end{array}$ & & \\
\hline \multirow[t]{2}{*}{ barley } & MS-GARCH & $\underset{(\mathrm{NaN})}{1.0010 e-08}$ & $\begin{array}{l}0.6120 \\
(\text { NaN) }\end{array}$ & $\begin{array}{l}0.3040 \\
(\text { NaN })\end{array}$ & & $\underbrace{0.7514}_{(\mathrm{NaN})}$ & $\begin{array}{c}0.8043 \\
(\text { NaN })\end{array}$ \\
\hline & & $\underset{(\mathrm{NaN})}{1.0461 e-01}$ & $\begin{array}{l}0.0465 \\
(\text { NaN })\end{array}$ & $\begin{array}{l}0.9370 \\
(\text { NaN })\end{array}$ & & & \\
\hline oats & ZGARCH & $\begin{array}{c}3.4541 e-02 \\
(3.3534 e-04)\end{array}$ & $\begin{array}{c}0.0833 \\
(2.5465 e-04)\end{array}$ & $\begin{array}{c}-0.0124 \\
(4.1649 e-04)\end{array}$ & $\begin{array}{c}0.9227 \\
(5.6002 e-04)\end{array}$ & & \\
\hline \multirow[t]{2}{*}{ rice } & MS-GARCH & $\frac{1.2373 e-02}{(4.4780 e-05)}$ & $\begin{array}{c}0.0244 \\
(1.0448 e-05)\end{array}$ & $\begin{array}{c}0.9656 \\
(2.6358 e-05)\end{array}$ & & $\begin{array}{c}0.6925 \\
(1.2590 e-02)\end{array}$ & $\begin{array}{c}0.0001 \\
(7.1565 e-03)\end{array}$ \\
\hline & & $\begin{array}{c}2.1154 e-01 \\
(8.0178 e-02)\end{array}$ & $\begin{array}{c}0.8893 \\
(1.2661 e-02)\end{array}$ & $\begin{array}{c}0.0789 \\
(6.0380 e-02)\end{array}$ & & & \\
\hline \multirow[t]{2}{*}{ palm oil } & MS-GARCH & $\begin{array}{c}2.9441 e-02 \\
(1.4478 e-03)\end{array}$ & $\begin{array}{c}0.0789 \\
(1.1713 e-03)\end{array}$ & $\begin{array}{c}0.9028 \\
(3.4784 e-03)\end{array}$ & & $\begin{array}{c}0.9999 \\
(1.0655 e-07)\end{array}$ & $\begin{array}{c}0.9983 \\
(1.6577 e-05)\end{array}$ \\
\hline & & $\begin{array}{c}1.6166 e-02 \\
(7.9705 e-04)\end{array}$ & $\begin{array}{c}0.0838 \\
(4.2815 e-02)\end{array}$ & $\begin{array}{c}0.8633 \\
(9.6842 e-03)\end{array}$ & & & \\
\hline
\end{tabular}


(continued)

\begin{tabular}{|c|c|c|c|c|c|c|c|}
\hline Series & Model selected & $\omega$ & $\alpha$ & $\beta$ & $\gamma$ & $p_{11}$ & $p_{22}$ \\
\hline cocoa & EGARCH & $\begin{array}{c}4.1313 e-03 \\
(6.0467 e-06)\end{array}$ & $\begin{array}{c}0.0582 \\
(1.7471 e-04)\end{array}$ & $\begin{array}{c}0.0246 \\
(1.0288 e-04)\end{array}$ & $\begin{array}{c}0.9988 \\
(4.7266 e-06)\end{array}$ & & \\
\hline \multirow[t]{2}{*}{ sugar } & MS-GARCH & $\begin{array}{c}8.4331 e-02 \\
(1.1072 e-01)\end{array}$ & $\begin{array}{c}0.0506 \\
(8.3640 e-03)\end{array}$ & $\begin{array}{c}0.9258 \\
(2.9924 e-02)\end{array}$ & & $\begin{array}{c}0.9990 \\
(7.4942 e-06)\end{array}$ & $\begin{array}{c}0.9995 \\
(7.1889 e-07)\end{array}$ \\
\hline & & $\begin{array}{c}6.0628 e-01 \\
(3.2954 e-02)\end{array}$ & $\begin{array}{c}0.3124 \\
(4.8568 e-02)\end{array}$ & $\begin{array}{c}0.1341 \\
(5.8743 e-02)\end{array}$ & & & \\
\hline \multirow[t]{2}{*}{ lumber } & MS-GARCH & $\begin{array}{c}4.9197 e-03 \\
(1.9011 e-04)\end{array}$ & $\begin{array}{c}0.0195 \\
(2.3929 e-01)\end{array}$ & $\begin{array}{c}0.9691 \\
(5.9801 e-01)\end{array}$ & & $\begin{array}{c}0.9557 \\
(7.7735 e-03)\end{array}$ & $\begin{array}{c}0.9241 \\
(3.6866 e+00)\end{array}$ \\
\hline & & $\begin{array}{c}2.9329 e-02 \\
(3.9606 e-01)\end{array}$ & $\begin{array}{c}0.0158 \\
(1.3726 e-01)\end{array}$ & $\begin{array}{c}0.9742 \\
(5.7062 e-03)\end{array}$ & & & \\
\hline \multirow[t]{2}{*}{ sunflowers } & MS-GARCH & $\begin{array}{c}4.7647 e-02 \\
(2.5010 e-03)\end{array}$ & $\begin{array}{c}0.0278 \\
(2.0466 e-04)\end{array}$ & $\begin{array}{c}0.9622 \\
(7.4464 e-04)\end{array}$ & & $\begin{array}{c}0.7659 \\
(1.7077 e-02)\end{array}$ & $\begin{array}{c}0.8984 \\
(2.7995 e-03)\end{array}$ \\
\hline & & $\begin{array}{c}2.0278 e-03 \\
(2.2950 e-05)\end{array}$ & $\begin{array}{c}0.0008 \\
(2.2439 e-06)\end{array}$ & $\begin{array}{c}0.9892 \\
(7.4793 e-06)\end{array}$ & & & \\
\hline \multirow[t]{2}{*}{ lean hogs } & MS-GARCH & $\begin{array}{c}9.0529 e-03 \\
(6.4264 e-04)\end{array}$ & $\begin{array}{c}0.0199 \\
(6.2288 e-04)\end{array}$ & $\begin{array}{c}0.9701 \\
(3.0712 e-03)\end{array}$ & & $\begin{array}{c}0.9996 \\
(1.3801 e-05)\end{array}$ & $\begin{array}{c}0.9759 \\
(1.0910 e-02)\end{array}$ \\
\hline & & $\begin{array}{c}1.8811 e-03 \\
(1.7581 e-04)\end{array}$ & $\begin{array}{c}0.0083 \\
(4.7805 e-04)\end{array}$ & $\begin{array}{c}0.9659 \\
(2.6512 e-03)\end{array}$ & & & \\
\hline \multirow[t]{2}{*}{ live cattle } & MS-GARCH & $\begin{array}{c}3.8436 e-03 \\
(2.8058 e-05)\end{array}$ & $\begin{array}{c}0.0336 \\
(1.8011 e-03)\end{array}$ & $\begin{array}{c}0.9564 \\
(4.7673 e-03)\end{array}$ & & $\begin{array}{c}0.9999 \\
(1.1201 e-07)\end{array}$ & $\begin{array}{c}0.2693 \\
(1.7931 e-01)\end{array}$ \\
\hline & & $\begin{array}{c}1.0000 e+00 \\
(1.3146 e+01)\end{array}$ & $\begin{array}{c}0.0058 \\
(2.2217 e-05)\end{array}$ & $\begin{array}{c}0.9842 \\
(2.5613 e-03)\end{array}$ & & & \\
\hline \multirow[t]{3}{*}{ feeder cattle } & MS-GARCH & $\begin{array}{c}3.5116 e-01 \\
(1.6743 e+01)\end{array}$ & $\begin{array}{c}0.0000 \\
(5.5795 e-02)\end{array}$ & $\begin{array}{c}0.2355 \\
(6.0132 e+01)\end{array}$ & & $\begin{array}{c}0.9816 \\
(8.0693 e-03)\end{array}$ & $\begin{array}{c}0.9958 \\
(8.1210 e-04)\end{array}$ \\
\hline & & $\begin{array}{c}4.7135 e-03 \\
(2.9152 e-04)\end{array}$ & $\begin{array}{c}0.0413 \\
(1.1124 e-02) \\
\end{array}$ & $\begin{array}{c}0.9487 \\
(2.5852 e-02) \\
\end{array}$ & & & \\
\hline & & & Indices & & & & \\
\hline VIX & EGARCH & $\begin{array}{c}1.1350 e-01 \\
(1.3346 e-03)\end{array}$ & $\begin{array}{c}0.0996 \\
(6.3152 e-04)\end{array}$ & $\begin{array}{c}0.1672 \\
(5.4744 e-04)\end{array}$ & $\begin{array}{c}0.9670 \\
(1.1120 e-04)\end{array}$ & & \\
\hline \multirow[t]{2}{*}{ SP500 } & MS-GARCH & $\begin{array}{c}4.9183 e-02 \\
(5.3981 e-02)\end{array}$ & $\begin{array}{c}0.0556 \\
(4.2632 e-02)\end{array}$ & $\begin{array}{c}0.8413 \\
(2.5869 e-01)\end{array}$ & & $\begin{array}{c}0.9995 \\
(5.0638 e-06)\end{array}$ & $\begin{array}{c}0.9994 \\
(1.1186 e-05)\end{array}$ \\
\hline & & $\begin{array}{c}2.4107 e-02 \\
(2.4592 e-03)\end{array}$ & $\begin{array}{c}0.1000 \\
(2.6226 e-03)\end{array}$ & $\begin{array}{c}0.8900 \\
(8.4038 e-03)\end{array}$ & & & \\
\hline \multirow[t]{2}{*}{ JPMUSU } & MS-GARCH & $\begin{array}{c}1.0856 e-03 \\
(4.9872 e-07)\end{array}$ & $\begin{array}{c}0.0335 \\
(6.4647 e-04)\end{array}$ & $\begin{array}{c}0.9565 \\
(1.5833 e-03)\end{array}$ & & $\begin{array}{c}0.9990 \\
(1.5998 e-03)\end{array}$ & $\begin{array}{c}0.9963 \\
(2.6250 e-03)\end{array}$ \\
\hline & & $\begin{array}{c}2.9642 e-02 \\
(1.2352 e+00)\end{array}$ & $\begin{array}{c}0.0000 \\
(5.0359 e-04)\end{array}$ & $\begin{array}{c}0.1875 \\
(6.2549 e+02)\end{array}$ & & & \\
\hline \multirow[t]{2}{*}{ DJUBS } & MS-GARCH & $\begin{array}{c}1.1674 e-02 \\
(9.3626 e-05)\end{array}$ & $\begin{array}{c}0.0235 \\
(5.7099 e-03)\end{array}$ & $\begin{array}{c}0.9453 \\
(1.0291 e-02)\end{array}$ & & $\begin{array}{c}0.9999 \\
(9.7316 e-08)\end{array}$ & $\begin{array}{c}0.9999 \\
(7.1567 e-07)\end{array}$ \\
\hline & & $\begin{array}{c}1.5522 e-02 \\
(1.3240 e-04)\end{array}$ & $\begin{array}{c}0.0359 \\
(5.1784 e-03)\end{array}$ & $\begin{array}{c}0.9518 \\
(1.3850 e-02)\end{array}$ & & & \\
\hline \multirow[t]{2}{*}{ GSCI } & MS-GARCH & $\frac{2.4345 e-02}{(6.5711 e-05)}$ & $\begin{array}{c}0.0357 \\
(4.7810 e-05)\end{array}$ & $\begin{array}{c}0.9538 \\
(1.2578 e-04)\end{array}$ & & $\begin{array}{c}0.9998 \\
(8.6194 e-08)\end{array}$ & $\begin{array}{c}0.9999 \\
(3.1685 e-08)\end{array}$ \\
\hline & & $\begin{array}{c}1.2342 e-02 \\
(1.0187 e-03)\end{array}$ & $\begin{array}{c}0.0338 \\
(1.3248 e-03)\end{array}$ & $\begin{array}{c}0.9408 \\
(2.2630 e-03)\end{array}$ & & & \\
\hline \multirow[t]{2}{*}{ RICI } & MS-GARCH & $\begin{array}{c}7.1324 e-03 \\
(9.0938 e-05)\end{array}$ & $\begin{array}{c}0.0323 \\
(4.7074 e-03)\end{array}$ & $\begin{array}{c}0.9471 \\
(7.9218 e-03)\end{array}$ & & $\begin{array}{c}0.9999 \\
(1.6773 e-08)\end{array}$ & $\begin{array}{c}0.9999 \\
(1.1999 e-07)\end{array}$ \\
\hline & & $\begin{array}{c}1.5454 e-02 \\
(3.0707 e-05)\end{array}$ & $\begin{array}{c}0.0342 \\
(1.7877 e-05)\end{array}$ & $\begin{array}{c}0.9555 \\
(4.8004 e-05)\end{array}$ & & & \\
\hline \multirow[t]{2}{*}{ JFCRB } & MS-GARCH & $\begin{array}{c}1.4801 e-02 \\
(2.9056 e-05)\end{array}$ & $\begin{array}{c}0.0342 \\
(4.6830 e-04)\end{array}$ & $\begin{array}{c}0.9543 \\
(1.2954 e-03)\end{array}$ & & $\begin{array}{c}0.9999 \\
(1.3861 e-07)\end{array}$ & $\begin{array}{c}0.9999 \\
(1.5871 e-08)\end{array}$ \\
\hline & & $\begin{array}{c}7.7973 e-03 \\
(1.0210 e-04)\end{array}$ & $\begin{array}{c}0.0195 \\
(3.6970 e-03)\end{array}$ & $\begin{array}{c}0.9566 \\
(6.3312 e-03)\end{array}$ & & & \\
\hline \multirow[t]{2}{*}{ GSCIAG } & MS-GARCH & $\begin{array}{c}1.5359 e-02 \\
(1.1637 e-02)\end{array}$ & $\begin{array}{c}0.0589 \\
(1.0116 e-01)\end{array}$ & $\begin{array}{c}0.9311 \\
(2.2447 e-01)\end{array}$ & & $\begin{array}{c}0.9940 \\
(1.5336 e-04)\end{array}$ & $\begin{array}{c}0.9890 \\
(4.5541 e-03)\end{array}$ \\
\hline & & $\begin{array}{c}1.8503 e-02 \\
(9.5977 e-03)\end{array}$ & $\begin{array}{c}0.0118 \\
(1.5800 e-02)\end{array}$ & $\begin{array}{c}0.9782 \\
(3.5043 e-02)\end{array}$ & & & \\
\hline \multirow[t]{2}{*}{ GSCIIM } & MS-GARCH & $\begin{array}{c}8.3928 e-02 \\
(1.0234 e-02)\end{array}$ & $\begin{array}{c}0.0519 \\
(3.1973 e-04)\end{array}$ & $\begin{array}{c}0.9330 \\
(1.2395 e-03)\end{array}$ & & $\begin{array}{c}0.9774 \\
(7.1701 e-04)\end{array}$ & $\begin{array}{c}0.9839 \\
(1.2993 e-04)\end{array}$ \\
\hline & & $\begin{array}{c}9.0296 e-03 \\
(7.6561 e-05)\end{array}$ & $\begin{array}{c}0.0139 \\
(1.6351 e-04)\end{array}$ & $\begin{array}{c}0.9761 \\
(4.0548 e-04)\end{array}$ & & & \\
\hline GSCIEN & GARCH & $\begin{array}{c}4.0617 e-03 \\
(2.2171 e-05)\end{array}$ & $\begin{array}{c}0.0375 \\
(4.5764 e-05)\end{array}$ & $\begin{array}{c}0.9618 \\
(4.6106 e-05)\end{array}$ & & & \\
\hline \multirow[t]{2}{*}{ GSCILIVE } & MS-GARCH & $\begin{array}{c}9.1131 e-03 \\
(2.6223 e-05)\end{array}$ & $\begin{array}{c}0.0277 \\
(6.0262 e-05)\end{array}$ & $\begin{array}{c}0.9412 \\
(4.0599 e-04)\end{array}$ & & $\begin{array}{c}0.9990 \\
(8.6960 e-06)\end{array}$ & $\begin{array}{c}0.9998 \\
(4.6033 e-08)\end{array}$ \\
\hline & & $\begin{array}{c}7.9545 e-03 \\
(8.2759 e-06)\end{array}$ & $\begin{array}{c}0.0203 \\
(1.7611 e-05)\end{array}$ & $\begin{array}{c}0.9697 \\
(6.3003 e-05)\end{array}$ & & & \\
\hline \multirow[t]{2}{*}{ GSCIPM } & MS-GARCH & $\underset{(N a N)}{1.3491 e-08}$ & $\begin{array}{l}0.2165 \\
(\text { NaN })\end{array}$ & $\begin{array}{l}0.0787 \\
(\mathrm{NaN})\end{array}$ & & $\begin{array}{l}0.0001 \\
(\mathrm{NaN})\end{array}$ & $\begin{array}{c}0.6590 \\
(\mathrm{NaN})\end{array}$ \\
\hline & & $\begin{array}{c}3.2643 e-02 \\
(N a N)\end{array}$ & $\begin{array}{c}0.0416 \\
(\text { NaN })\end{array}$ & $\begin{array}{c}0.9484 \\
(\text { NaN })\end{array}$ & & & \\
\hline
\end{tabular}

Note: the estimation of the RSDC involves first extracting the univariate volatility of each series, Following ?, we tested seven GARCH models (all at first order): GARCH, EGARCH, FIGARCH, ZARCH, GJR-GARCH, AGARCH, NAGARCH, and adding MS-GARCH (?). This pool of models affords choice ranging from a simple GARCH model to specifications including asymmetry, threshold effects or long memory. The selection of the best model was based on a Bayesian information criterion. 
Table 2: Degarching: indices constructed from commodity futures returns.

\begin{tabular}{|c|c|c|c|c|c|c|}
\hline Series & Model selected & $\omega$ & $\alpha$ & $\beta$ & $p_{11}$ & $p_{22}$ \\
\hline \multirow[t]{2}{*}{ Total Non-Energy } & \multirow[t]{2}{*}{ MS-GARCH } & $\begin{array}{c}1.5639 e-03 \\
(4.5072 e-05)\end{array}$ & $\begin{array}{c}0.0156 \\
(1.1391 e-03)\end{array}$ & $\begin{array}{c}0.9744 \\
(4.7673 e-03)\end{array}$ & \multirow[t]{2}{*}{$\begin{array}{c}0.9819 \\
(6.5940 e-04)\end{array}$} & \multirow[t]{2}{*}{$\begin{array}{c}0.9540 \\
(1.8730 e-03\end{array}$} \\
\hline & & $\begin{array}{c}1.9298 e-02 \\
(1.2030 e-03)\end{array}$ & $\begin{array}{c}0.0492 \\
(3.1461 e-04)\end{array}$ & $\begin{array}{c}0.9408 \\
(6.5852 e-04)\end{array}$ & & \\
\hline \multirow[t]{2}{*}{ In-index Non-Energy } & \multirow[t]{2}{*}{ MS-GARCH } & $\begin{array}{c}3.0904 e-02 \\
(3.0238 e-02)\end{array}$ & $\begin{array}{c}0.0396 \\
(1.6988 e-03)\end{array}$ & $\begin{array}{c}0.9485 \\
(1.2555 e-02)\end{array}$ & \multirow[t]{2}{*}{$\begin{array}{c}0.9488 \\
(1.2362 e-03)\end{array}$} & \multirow[t]{2}{*}{$\begin{array}{c}0.9862 \\
(8.9576 e-04)\end{array}$} \\
\hline & & $\begin{array}{c}1.9211 e-03 \\
(1.2570 e-05)\end{array}$ & $\begin{array}{c}0.0161 \\
(4.6798 e-04)\end{array}$ & $\begin{array}{c}0.9739 \\
(1.0162 e-03)\end{array}$ & & \\
\hline \multirow[t]{2}{*}{ Off index Non-Energy } & \multirow[t]{2}{*}{ MS-GARCH } & $\begin{array}{c}2.2744 e-04 \\
(6.1649 e-08)\end{array}$ & $\begin{array}{c}0.0024 \\
(4.5903 e-07)\end{array}$ & $\begin{array}{c}0.9876 \\
(9.7672 e-06)\end{array}$ & \multirow[t]{2}{*}{$\begin{array}{c}0.8920 \\
(2.7119 e-04)\end{array}$} & \multirow[t]{2}{*}{$\begin{array}{c}0.9709 \\
(7.4021 e-05)\end{array}$} \\
\hline & & $\begin{array}{c}1.2887 e-02 \\
(4.7717 e-06)\end{array}$ & $\begin{array}{c}0.0397 \\
(2.7834 e-05) \\
\end{array}$ & $\begin{array}{c}0.9503 \\
(3.1846 e-05) \\
\end{array}$ & & \\
\hline \multirow[t]{2}{*}{ Energy } & \multirow[t]{2}{*}{ MS-GARCH } & $\begin{array}{c}2.0145 e-02 \\
(1.0434 e-04)\end{array}$ & $\begin{array}{c}0.0308 \\
(4.6297 e-05)\end{array}$ & $\begin{array}{c}0.9592 \\
(1.1005 e-04)\end{array}$ & \multirow[t]{2}{*}{$\begin{array}{c}0.9998 \\
(1.4736 e-08)\end{array}$} & \multirow[t]{2}{*}{$\begin{array}{c}0.9996 \\
(1.5116 e-07)\end{array}$} \\
\hline & & $\begin{array}{c}3.3111 e-02 \\
(3.7778 e-04)\end{array}$ & $\begin{array}{c}0.0175 \\
(2.9294 e-04)\end{array}$ & $\begin{array}{c}0.9205 \\
(8.7385 e-04)\end{array}$ & & \\
\hline \multirow[t]{2}{*}{ Precious Metals } & \multirow[t]{2}{*}{ MS-GARCH } & $\begin{array}{c}1.0405 e-02 \\
(9.5040 e-05)\end{array}$ & $\begin{array}{c}0.0212 \\
(3.9151 e-05)\end{array}$ & $\begin{array}{c}0.9688 \\
(1.7555 e-04)\end{array}$ & \multirow[t]{2}{*}{$\begin{array}{c}0.9920 \\
(2.1402 e-04)\end{array}$} & \multirow[t]{2}{*}{$\begin{array}{c}0.9279 \\
(1.0756 e-02)\end{array}$} \\
\hline & & $\begin{array}{c}1.0000 e+00 \\
(1.6738 e+00)\end{array}$ & $\begin{array}{c}0.2385 \\
(8.8066 e-02)\end{array}$ & $\begin{array}{c}0.5800 \\
(3.9972 e-02)\end{array}$ & & \\
\hline \multirow[t]{2}{*}{ Industrial Metals } & \multirow[t]{2}{*}{ MS-GARCH } & $\begin{array}{c}6.9173 e-03 \\
(2.6123 e-05)\end{array}$ & $\begin{array}{c}0.0146 \\
(6.0577 e-05)\end{array}$ & $\begin{array}{c}0.9754 \\
(2.9785 e-04)\end{array}$ & \multirow[t]{2}{*}{$\begin{array}{c}0.9729 \\
(3.4276 e-03)\end{array}$} & \multirow[t]{2}{*}{$\begin{array}{c}0.9649 \\
(6.1810 e-03)\end{array}$} \\
\hline & & $\begin{array}{c}6.4443 e-02 \\
(5.1759 e-03)\end{array}$ & $\begin{array}{c}0.0433 \\
(2.1565 e-03)\end{array}$ & $\begin{array}{c}0.9467 \\
(2.2559 e-03)\end{array}$ & & \\
\hline \multirow[t]{2}{*}{ Agriculture } & \multirow[t]{2}{*}{ MS-GARCH } & $\begin{array}{c}7.0939 e-03 \\
(3.4686 e-01)\end{array}$ & $\begin{array}{c}0.0390 \\
(3.4923 e+00)\end{array}$ & $\begin{array}{c}0.9510 \\
(8.4744 e+00)\end{array}$ & \multirow[t]{2}{*}{$\begin{array}{c}0.9995 \\
(7.1914 e-02)\end{array}$} & \multirow[t]{2}{*}{$\begin{array}{c}0.9642 \\
(2.0419 e+01)\end{array}$} \\
\hline & & $\begin{array}{c}8.4642 e-03 \\
(2.0039 e+02)\end{array}$ & $\begin{array}{c}0.2565 \\
(3.5394 e+00)\end{array}$ & $\begin{array}{c}0.7107 \\
(1.8346 e+03)\end{array}$ & & \\
\hline \multirow[t]{2}{*}{ Livestocks } & \multirow[t]{2}{*}{ MS-GARCH } & $\begin{array}{c}4.8543 e-03 \\
(4.6526 e-06)\end{array}$ & $\begin{array}{c}0.0304 \\
(1.2411 e-04)\end{array}$ & $\begin{array}{c}0.9574 \\
(3.2213 e-04)\end{array}$ & \multirow[t]{2}{*}{$\begin{array}{c}0.9998 \\
(2.3239 e-05)\end{array}$} & \multirow[t]{2}{*}{$\begin{array}{c}0.9994 \\
(3.8173 e-05)\end{array}$} \\
\hline & & $\begin{array}{c}4.9928 e-03 \\
(7.2303 e-03)\end{array}$ & $\begin{array}{c}0.0462 \\
(1.2021 e-01)\end{array}$ & $\begin{array}{c}0.9264 \\
(7.8353 e-01)\end{array}$ & & \\
\hline \multirow[t]{2}{*}{ Grains } & \multirow[t]{2}{*}{ MS-GARCH } & $\begin{array}{c}2.3836 e-02 \\
(1.4721 e-03)\end{array}$ & $\begin{array}{c}0.0329 \\
(5.4839 e-04)\end{array}$ & $\begin{array}{c}0.9567 \\
(1.2844 e-03)\end{array}$ & \multirow[t]{2}{*}{$\begin{array}{c}0.9996 \\
(3.8478 e-06)\end{array}$} & $\begin{array}{c}0.9998 \\
(2.9954 e-07)\end{array}$ \\
\hline & & $\begin{array}{c}3.0100 e-02 \\
(3.7243 e-03)\end{array}$ & $\begin{array}{c}0.0384 \\
(5.8713 e-04)\end{array}$ & $\begin{array}{c}0.9309 \\
(5.0066 e-03)\end{array}$ & & \\
\hline Soft & MS-GARCH & $\begin{array}{c}1.6159 e-02 \\
(5.3559 e-04)\end{array}$ & $\begin{array}{c}0.0963 \\
(2.1400 e-03)\end{array}$ & $\begin{array}{c}0.8937 \\
(3.0980 e-03)\end{array}$ & $\begin{array}{c}0.9765 \\
(3.3517 e-03)\end{array}$ & $\begin{array}{c}0.9849 \\
(6.6460 e-04)\end{array}$ \\
\hline & & $\begin{array}{c}7.0659 e-03 \\
(1.9291 e-04)\end{array}$ & $\begin{array}{c}0.0125 \\
(2.8248 e-04) \\
\end{array}$ & $\begin{array}{c}0.9775 \\
(1.1899 e-03)\end{array}$ & & \\
\hline
\end{tabular}

(a) Equally-weighted constructed commodity indices.

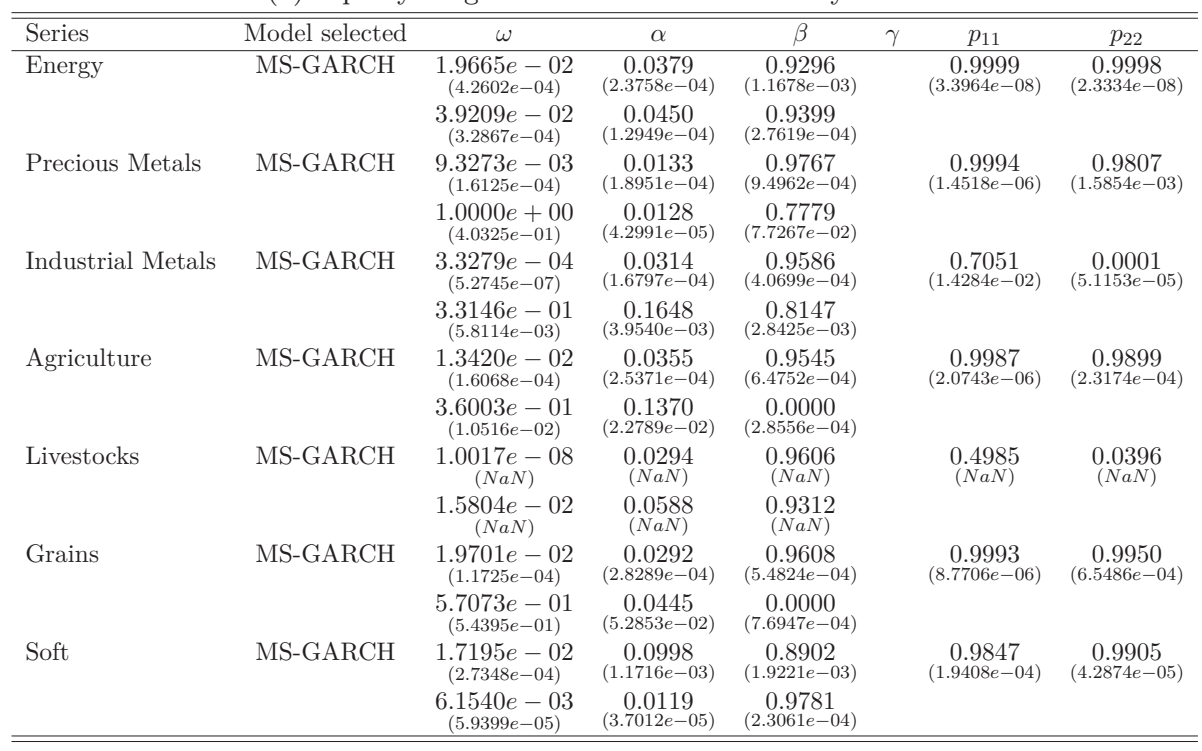

(b) commodity indices using GSCI weights. 


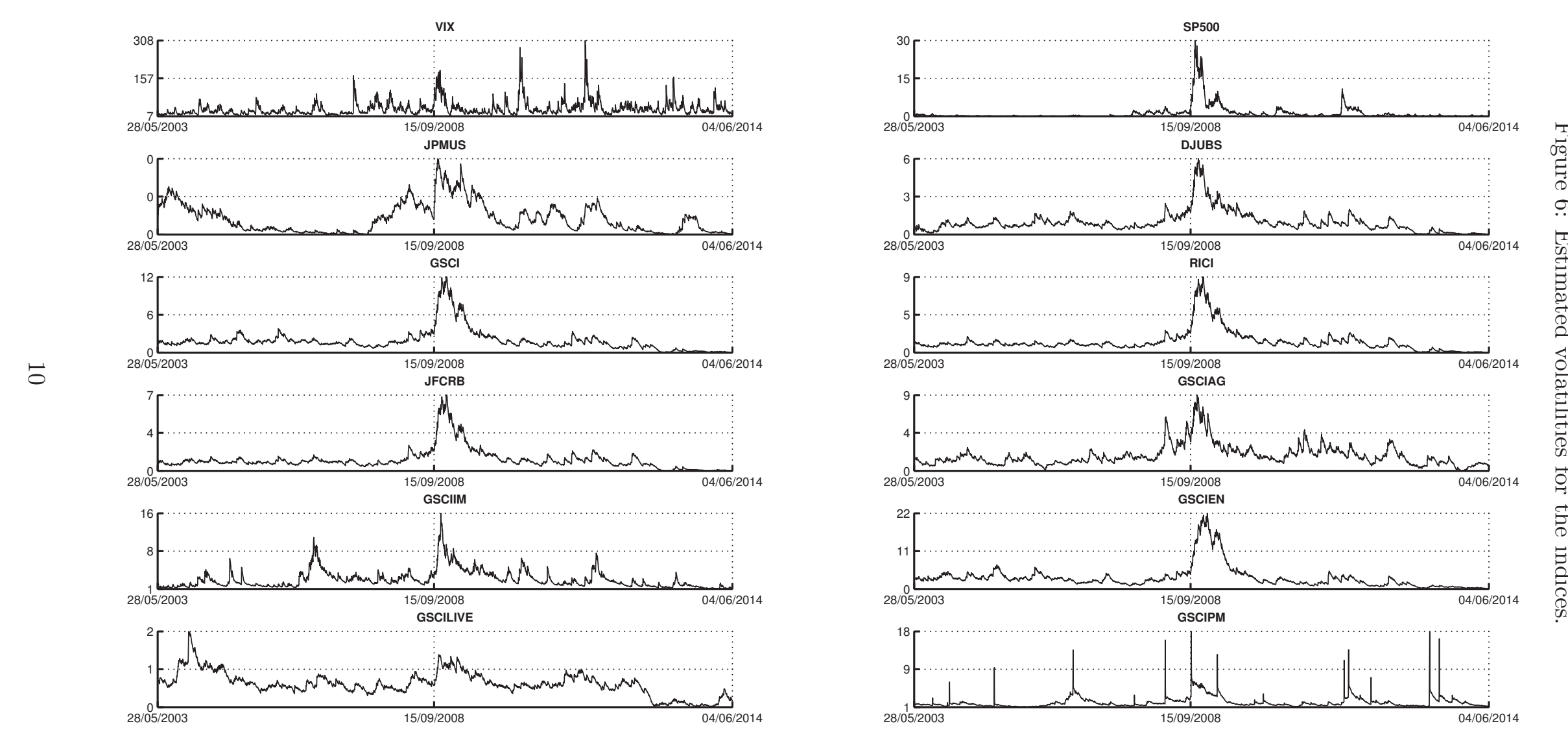


\section{RSDC estimated parameters}

In this section, we provide estimated parameters from RSDC model. $\hat{R}_{i}$ represents the estimated correlation matrix (see equation (5) in the paper), $\hat{C}_{i}$ represents the estimated covariance matrix of the regime $i$ (see equation (13)) and $\hat{P}$ represents the estimated transition matrix (see equation (12)). Standard errors (values in brackets) are given only for bivariate estimations, results from multivariate estimations are available upon request.

Table 3: Co-movements across the full range of commodities.

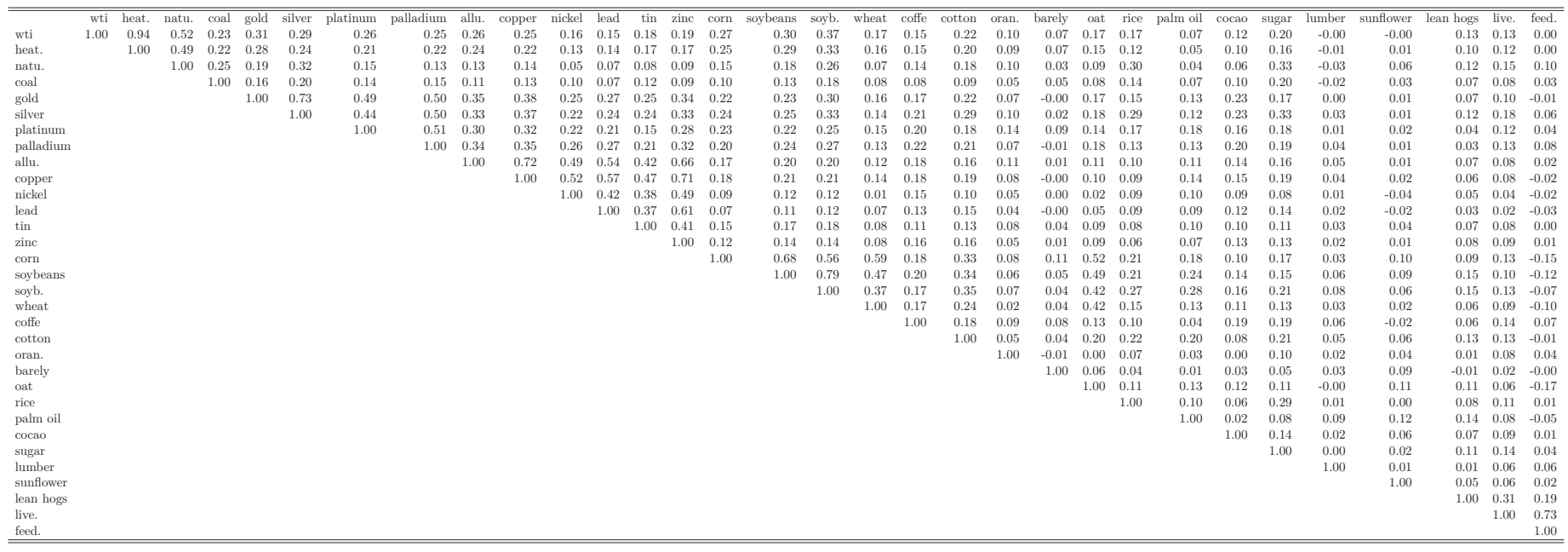

(a) $\hat{R}_{1}$

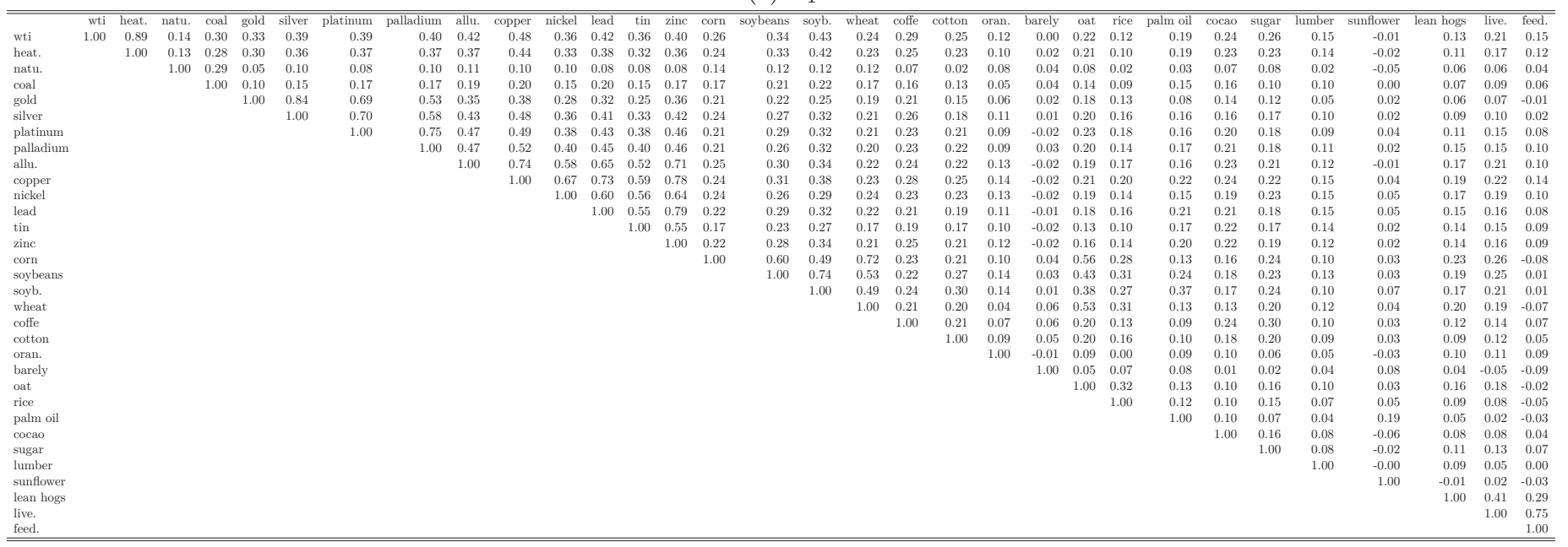

(b) $\hat{R}_{2}$

$$
\mathrm{P}=\left[\begin{array}{ll}
0.9589 & 0.0533 \\
0.0411 & 0.9467
\end{array}\right]
$$

(c) $\hat{P}$ 
Table 4: Co-movements across the In-index commodities.

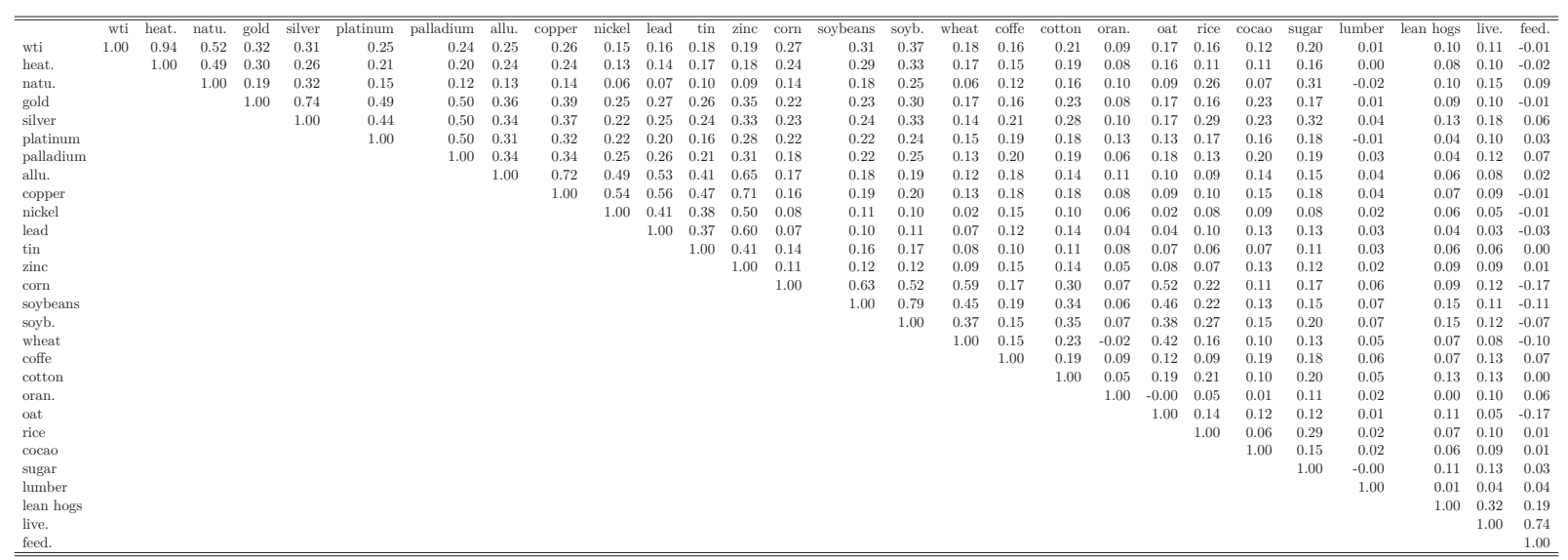

(a) $\hat{R}_{1}$

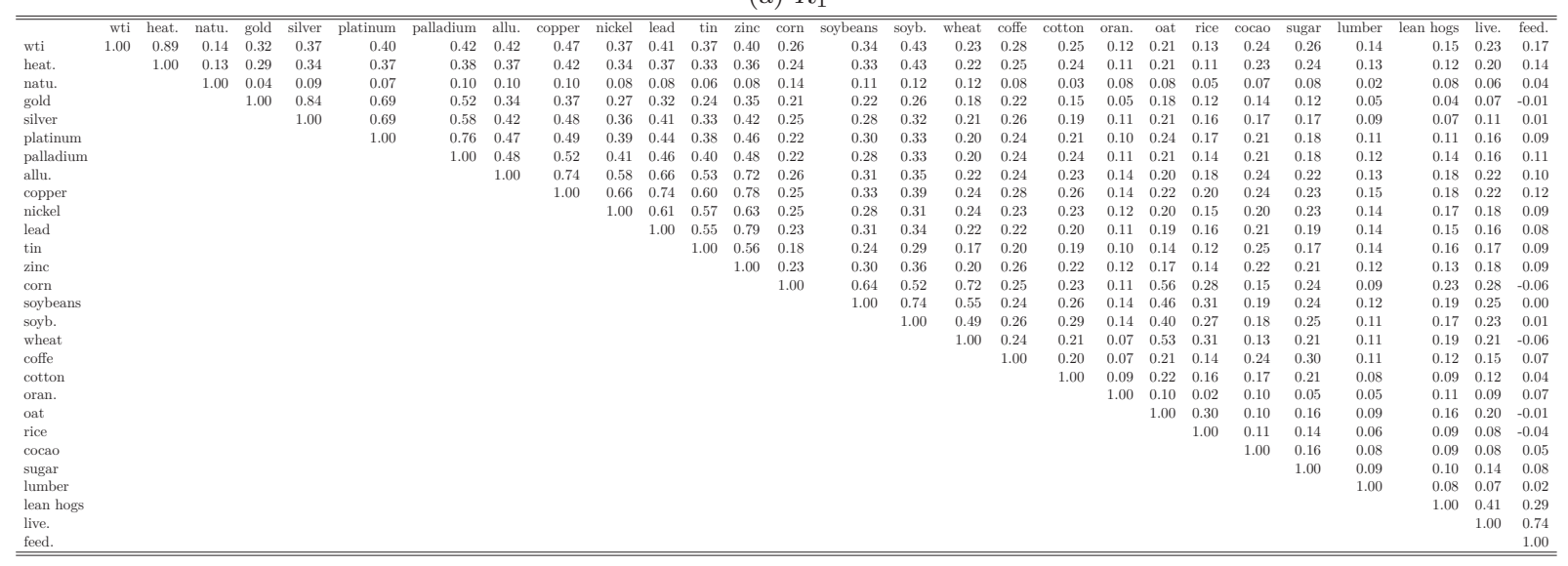

(b) $\hat{R}_{2}$

$\mathrm{P}=\left[\begin{array}{ll}0.9850 & 0.0182 \\ 0.0150 & 0.9818\end{array}\right]$

(c) $\hat{P}$

Table 5: Co-movements across Off-index commodities.

\begin{tabular}{lrrrr}
\hline \hline & coal & barely & palm oil & sunflower \\
coal & 1.00 & 0.04 & 0.06 & 0.00 \\
barely & & 1.00 & -0.00 & 0.06 \\
palm oil & & & 1.00 & 0.05 \\
sunflower & & & & 1.00 \\
\hline \hline
\end{tabular}

\begin{tabular}{lrrrr}
\hline \hline \multicolumn{5}{c}{ (a) $\hat{R}_{1}$} \\
\hline \hline \\
\hline \multirow{3}{c}{ coal } & coal & barely & palm oil & sunflower \\
barely & 1.00 & 0.05 & 0.19 & 0.04 \\
palm oil & & 1.00 & 0.12 & 0.14 \\
sunflower & & & 1.00 & 0.30 \\
\hline \hline
\end{tabular}

(b) $\hat{R}_{2}$

$$
\mathrm{P}=\left[\begin{array}{ll}
0.9891 & 0.0092 \\
0.0109 & 0.9908
\end{array}\right]
$$

(c) $\hat{P}$ 
Table 6: Co-movements between Non-Energy commodities with WTI.

\begin{tabular}{|c|c|c|c|c|c|c|c|c|c|c|c|c|c|c|c|c|c|c|c|c|c|}
\hline & \multicolumn{3}{|c|}{$\frac{\hat{R}_{1}}{1}$} & \multicolumn{3}{|c|}{$\frac{\hat{R}_{2}}{2}$} & \multicolumn{3}{|c|}{$\frac{\hat{R}_{3}}{2}$} & \multicolumn{3}{|c|}{$\hat{C}_{1}$} & \multicolumn{3}{|c|}{$\bar{C}_{2}$} & \multicolumn{3}{|c|}{$\bar{C}_{3}$} & \multicolumn{3}{|c|}{$\hat{P}$} \\
\hline Total Non-Energy (TNE) & $\begin{array}{l}W T I \\
T N E\end{array}$ & $\begin{array}{c}W T I \\
1.00\end{array}$ & $\left.\begin{array}{c}T N E \\
0.28 \\
1.00\end{array}\right]$ & $\begin{array}{l}W T I \\
T N E\end{array}$ & $\begin{array}{c}W T I \\
1.00\end{array}$ & $\left.\begin{array}{r}T N E \\
0.73 \\
1.00\end{array}\right]$ & $\begin{array}{l}W T I \\
T N E\end{array}$ & $\begin{array}{c}W T I \\
1.00\end{array}$ & $\left.\begin{array}{c}T N E \\
0.67 \\
1.00\end{array}\right]$ & $\begin{array}{l}\text { WTI } \\
\text { TNE }\end{array}$ & $\begin{array}{c}W T I \\
0.5343 \\
(6.0378 e-01)\end{array}$ & \begin{tabular}{|c|}
$T N E$ \\
0.142 \\
$(3.6624 e-02)$ \\
0.55170 \\
$(5.5510 e-01)$ \\
\end{tabular} & $\begin{array}{l}W T I \\
T N E\end{array}$ & $\begin{array}{c}W T I \\
0.1381 \\
(1.16438-01)\end{array}$ & $\begin{array}{c}T N E \\
0.1059 \\
(6.1134 e-02) \\
0.1533 \\
(1.43766-01) \\
\end{array}$ & $\begin{array}{l}W T I \\
T N E\end{array}$ & $\begin{array}{c}W T I \\
0.3274 \\
(3.3395 e-02)\end{array}$ & \begin{tabular}{|c|}
$T N E$ \\
0.2256 \\
$(1.6490 e-02)$ \\
0.3464 \\
$(3.73876-02)$
\end{tabular} & 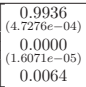 & $\begin{array}{c}0.00000 \\
\left(\begin{array}{c}0.6400 e-05) \\
0.9970 \\
(1.4924 e-06) \\
0.0030\end{array}\right.\end{array}$ & $\begin{array}{c}0.0036 \\
(5.64342-05) \\
0.0067 \\
(1.80907 e-05) \\
0.9897\end{array}$ \\
\hline In-index Non-Energy (INE) & $\begin{array}{l}\text { WTI } \\
\text { INE }\end{array}$ & $\begin{array}{c}W T I \\
1.00\end{array}$ & $\left.\begin{array}{c}I N E \\
0.28 \\
1.00\end{array}\right]$ & {$\left[\begin{array}{l}W T I \\
I N E\end{array}\right.$} & $\begin{array}{c}W T I \\
1.00\end{array}$ & $\left.\begin{array}{r}I N E \\
0.73 \\
1.00\end{array}\right]$ & {$\left[\begin{array}{l}W T I \\
I N E\end{array}\right.$} & $\begin{array}{c}W T I \\
1.00\end{array}$ & $\left.\begin{array}{c}I N E \\
0.68 \\
1.00\end{array}\right]$ & $\begin{array}{l}W T I \\
I N E\end{array}$ & $\begin{array}{c}W T I \\
0.5385 \\
(2.4704 e+00)\end{array}$ & $\left.\begin{array}{|c|}I N E \\
0.1507 \\
(2.02777 e-01) \\
0.5238 \\
(2.3212 e+00)\end{array}\right]$ & $\begin{array}{l}W T I \\
I N E\end{array}$ & $\begin{array}{c}W T I \\
(0.1261 \\
(7.3432 e-02)\end{array}$ & $\left.\begin{array}{c}I N E \\
0.091 \\
(3.54440 e-02) \\
0.1403 \\
(9.0252 e-02)\end{array}\right]$ & $\begin{array}{l}W T I \\
I N E\end{array}$ & $\begin{array}{c}W T I \\
(0.3353 \\
(2.7208 e+00)\end{array}$ & $\left.\begin{array}{|c|}I N E \\
0.2326 \\
(1.39393+00) \\
0.3540 \\
(3.0245 e+00)\end{array}\right]$ & $\begin{array}{c}0.9935 \\
\left(\begin{array}{c}0.9748 e-03) \\
0.000 \\
(1.2731 e-05) \\
0.0065\end{array}\right. \\
0\end{array}$ & 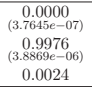 & $\begin{array}{c}.00037 \\
(5.4955-06) \\
0.0061 \\
(1.1061 e-05) \\
0.9902\end{array}$ \\
\hline Off index Non-Energy (ONE) & $\begin{array}{l}W T I \\
\text { ONE }\end{array}$ & $\begin{array}{c}W T I \\
1.00\end{array}$ & $\left.\begin{array}{c}O N E \\
0.00 \\
1.00\end{array}\right]$ & $\begin{array}{l}W T I \\
\text { ONE }\end{array}$ & $\begin{array}{c}W T I \\
1.00\end{array}$ & $\left.\begin{array}{c}O N E \\
0.17 \\
1.00\end{array}\right]$ & & & & $\begin{array}{l}W T I \\
O N E\end{array}$ & $\begin{array}{c}W T I \\
0.5028 \\
(8.1248 e-03)\end{array}$ & $\begin{array}{c}O N E \\
0.0020 \\
(3.7862 e-05) \\
0.5382 \\
(1.7982 e-02)\end{array}$ & $\begin{array}{l}W T I \\
O N E\end{array}$ & $\begin{array}{c}W T I \\
0.4971 \\
(7.8463 e-02)\end{array}$ & $\left.\begin{array}{c}O N E \\
0.0849 \\
(2.5446-03) \\
0.4791 \\
(7.2133 e-02)\end{array}\right]$ & & & & & $\begin{array}{lr}989 & 0.07 \\
0.06) & (7.612 \\
011 & 0.9\end{array}$ & $\left.\begin{array}{l}010 \\
27 e-07) \\
9990\end{array}\right]$ \\
\hline
\end{tabular}

(a) Total, In- and off-index commodities with WTI.

\begin{tabular}{|c|c|c|c|c|c|c|c|c|c|c|c|c|c|c|c|c|c|}
\hline & \multicolumn{3}{|c|}{$\hat{R}_{1}$} & \multicolumn{3}{|c|}{$\hat{R}_{2}$} & \multicolumn{3}{|c|}{$\bar{R}_{3}$} & \multicolumn{3}{|c|}{$\tilde{C}_{1}$} & \multicolumn{2}{|l|}{$\widehat{C}_{2}$} & \multicolumn{2}{|l|}{$\hat{C}_{3}$} & $\hat{P}$ \\
\hline Precious & $\begin{array}{l}\text { WTI } \\
\text { Prec. }\end{array}$ & $\begin{array}{c}W T I \\
1.00\end{array}$ & $\left.\begin{array}{r}\text { Prec. } \\
0.52 \\
1.00\end{array}\right]$ & $\begin{array}{l}\text { WTI } \\
\text { Prec. }\end{array}$ & $\begin{array}{l}W T I \\
1.00\end{array}$ & $\left.\begin{array}{c}\text { Prec. } \\
0.10 \\
1.00\end{array}\right]$ & & & & $\begin{array}{l}\text { WTI } \\
\text { Prec. }\end{array}$ & $\begin{array}{c}W T I \\
0.5373 \\
(7.2465 e-02)\end{array}$ & \begin{tabular}{c|} 
Prec. \\
0.2918 \\
$(2.1473-02)$ \\
0.5756 \\
$(8.3144-02)$
\end{tabular} & \begin{tabular}{|cc} 
& $W T I$ \\
WTI & 0.4608 \\
& $(1.9037 e-02)$ \\
Prec. &
\end{tabular} & $\begin{array}{c}\text { Prec. } \\
0.040 \\
\left(\begin{array}{c}0.2287 e-03) \\
0.448 \\
(1.8108 e-02)\end{array}\right) \\
\end{array}$ & & & {$\left[\begin{array}{cc}0.9757 & 0.0216 \\
(1.43636 e-04) & (2.0094-04) \\
0.0243 & 0.9784\end{array}\right]$} \\
\hline Industrial & $\begin{array}{l}\text { WTI } \\
\text { Indus. }\end{array}$ & $\begin{array}{c}W T I \\
1.00\end{array}$ & $\left.\begin{array}{c}\text { Indus. } \\
0.18 \\
1.00\end{array}\right]$ & $\begin{array}{c}\text { WTI } \\
\text { Indus. }\end{array}$ & $\begin{array}{l}W T I \\
1.00\end{array}$ & $\left.\begin{array}{c}\text { Indus. } \\
0.62 \\
1.00\end{array}\right]$ & $\begin{array}{c}\text { WTI } \\
\text { Indus. }\end{array}$ & $\begin{array}{l}W T I \\
1.00\end{array}$ & $\left.\begin{array}{c}\text { Indus. } \\
0.43 \\
1.00\end{array}\right]$ & $\begin{array}{l}\text { WTI } \\
\text { Indus. }\end{array}$ & $\begin{array}{c}W T I \\
0.6140 \\
(1.2093 e+01)\end{array}$ & $\begin{array}{c}\text { Indus. } \\
0.1125 \\
(3.5889 e-01 \\
0.602 \\
(1.1712 e+01)\end{array}$ & $\begin{array}{|cc|} & W T I \\
\text { WTI } & 0.1767 \\
& (3.2298 e-01) \\
\text { Indus. } & \end{array}$ & $\begin{array}{c}\text { Indus. } \\
0.1123 \\
(5.42626-02) \\
0.1845 \\
(3.5284 e-01)\end{array}$ & $\begin{array}{cc} & \text { WTI } \\
\text { WTI } & 0.2075 \\
& (6.2964 e-02) \\
\text { Indus. } & \end{array}$ & $\begin{array}{c}\text { Indus. } \\
0.0915 \\
(4.1674 \text { - } 02) \\
0.2175 \\
(6.8243 e-02)\end{array}$ & 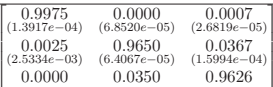 \\
\hline Agriculture & $\begin{array}{l}\text { WTI } \\
\text { Agri. }\end{array}$ & $\begin{array}{l}W T I \\
1.00\end{array}$ & $\left.\begin{array}{c}\text { Agri. } \\
0.24 \\
1.00\end{array}\right]$ & $\begin{array}{l}\text { WTI } \\
\text { Agri. }\end{array}$ & $\begin{array}{l}W T I \\
1.00\end{array}$ & $\left.\begin{array}{r}\text { Agri. } \\
0.72 \\
1.00\end{array}\right]$ & {$\left[\begin{array}{l}\text { WTI } \\
\text { Agri. }\end{array}\right.$} & $\begin{array}{c}W T I \\
1.00\end{array}$ & $\left.\begin{array}{r}\text { Agri. } \\
0.48 \\
1.00\end{array}\right]$ & $\begin{array}{l}\text { WTI } \\
\text { Agri. }\end{array}$ & $\begin{array}{c}\begin{array}{c}W T I \\
0.6226 \\
(6.3101 e+00)\end{array} \\
\end{array}$ & 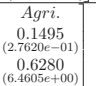 & $\begin{array}{lc} & W T I \\
W T I & 0.1483 \\
& (1.4533 e-02) \\
\text { Agri. } & \end{array}$ & 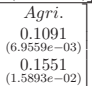 & \begin{tabular}{|lc} 
& $W T I$ \\
WTI & 0.2272 \\
& $(3.7020 e-02)$ \\
Agri. & \\
\end{tabular} & $\begin{array}{c}\text { Agri. } \\
0.1139 \\
\left(\begin{array}{c}1.0133 e-02) \\
0.2470 \\
(4.38800-02)\end{array}\right. \\
\end{array}$ & 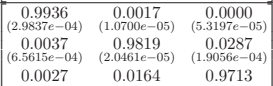 \\
\hline Live & $\begin{array}{l}\text { WTI } \\
\text { Live }\end{array}$ & $\begin{array}{l}W T I \\
1.00\end{array}$ & $\left.\begin{array}{l}\text { Live } \\
0.04 \\
1.00\end{array}\right]$ & $\begin{array}{l}\text { WTI } \\
\text { Live }\end{array}$ & $\begin{array}{l}W T I \\
1.00\end{array}$ & $\left.\begin{array}{l}\text { Live } \\
0.30 \\
1.00\end{array}\right]$ & & & & $\begin{array}{l}\text { WTI } \\
\text { Live }\end{array}$ & $\begin{array}{c}W T I \\
0.5446 \\
(4.1263 e-02)\end{array}$ & $\left.\begin{array}{c}\text { Live } \\
0.0221 \\
(2.2 .0322-04) \\
0.5381 \\
(4.3488 e-02\end{array}\right]$ & $\begin{array}{lc} & W T I \\
W T I & 0.4536 \\
\text { Live } & (7.5481 e-04) \\
\end{array}$ & $\left.\begin{array}{c}\text { Live } \\
0.1383 \\
(7.00616-05) \\
0.4552 \\
(9.0064-04)\end{array}\right]$ & & & {$\left[\begin{array}{cc}0.9989 & 0.0008 \\
(4.97355-06) & (5.3355 e-07) \\
0.0011 & 0.9992\end{array}\right]$} \\
\hline Grains & $\begin{array}{c}\text { WTI } \\
\text { Grains }\end{array}$ & $\begin{array}{l}W T I \\
1.00\end{array}$ & $\left.\begin{array}{c}\text { Grains } \\
0.18 \\
1.00\end{array}\right]$ & $\begin{array}{c}\text { WTI } \\
\text { Grains }\end{array}$ & $\begin{array}{l}W T I \\
1.00\end{array}$ & $\left.\begin{array}{c}\text { Grains } \\
0.63 \\
1.00\end{array}\right]$ & $\begin{array}{c}\text { WTI } \\
\text { Grains }\end{array}$ & $\begin{array}{c}W T I \\
1.00\end{array}$ & $\left.\begin{array}{c}\text { Grains } \\
0.31 \\
1.00\end{array}\right]$ & $\begin{array}{l}\text { WTI } \\
\text { Grains }\end{array}$ & $\begin{array}{c}W T I \\
0.5566 \\
(2.2598++00)\end{array}$ & $\left.\begin{array}{|l}\text { Grains } \\
0.097 \\
(6.0199 e-02) \\
0.557 \\
(2.4387 e+00)\end{array}\right]$ & \begin{tabular}{|cc} 
& $W T I$ \\
WTI & 0.1935 \\
& $(4.2147 e-02)$ \\
Grains & \\
\end{tabular} & $\begin{array}{c}\text { Grains } \\
0.1202 \\
(1.76944-02) \\
0.1894 \\
(4.0356 e-02) \\
\end{array}$ & \begin{tabular}{|cc} 
& $W T I$ \\
WTI & 0.2481 \\
& $(2.7191 e-01)$ \\
Grains &
\end{tabular} & $\begin{array}{c}\text { Grains } \\
0.0807 \\
(3.50511-02) \\
0.2668 \\
(3.12121 e-01)\end{array}$ & $\begin{array}{|ccc|}0.9982 & 0.0000 & 0.0007 \\
(2.1902 e-04) & (1.42525 e-06) & (1.3449 e-06) \\
0.0000 & 0.969 & 0.0378 \\
(1.9701 e-05) & (7.78868-07) & (1.8697 e-05) \\
0.0018 & 0.0301 & 0.9615 \\
\end{array}$ \\
\hline Soft & $\begin{array}{l}\text { WTI } \\
\text { Soft }\end{array}$ & $\begin{array}{l}W T I \\
1.00\end{array}$ & $\left.\begin{array}{l}\text { Soft } \\
0.16 \\
1.00\end{array}\right]$ & $\begin{array}{l}\text { WTI } \\
\text { Soft }\end{array}$ & $\begin{array}{l}W T I \\
1.00\end{array}$ & $\left.\begin{array}{c}\text { Soft } \\
0.62 \\
1.00\end{array}\right]$ & $\begin{array}{l}\text { WTI } \\
\text { Soft }\end{array}$ & $\begin{array}{c}W T I \\
1.00\end{array}$ & $\left.\begin{array}{c}\text { Soft } \\
0.36 \\
1.00\end{array}\right]$ & $\begin{array}{l}\text { WTI } \\
\text { Soft }\end{array}$ & $\begin{array}{c}\text { WTI } \\
0.5229 \\
(1.3232 e+01)\end{array}$ & $\left.\begin{array}{c}\text { Soft } \\
0.0809 \\
(2.8795 e-01) \\
0.5098 \\
(1.2576 e+01)\end{array}\right]$ & $\begin{array}{lc} & W T I \\
\text { WTI } & 0.2253 \\
\text { Soft } & (7.4899 e-02) \\
\text { Sof } & \\
\end{array}$ & $\left.\begin{array}{c}\text { Soft } \\
0.1426 \\
(3.8840 e-02) \\
0.2325 \\
(7.92929-02)\end{array}\right]$ & \begin{tabular}{|cc} 
& $W T I$ \\
WTI & 0.2500 \\
& $(5.7437 e-02)$ \\
Soft &
\end{tabular} & $\left.\begin{array}{c}\text { Soft } \\
0.0067 \\
(7.73996-03) \\
0.2831 \\
(7.3691 e-02)\end{array}\right]$ & $\begin{array}{|ccc|}0.9946 & 0.0026 & 0.0000 \\
(5.8385 e-04) & (3.34212 e-04) & (8.99918 e-05) \\
0.0001 & 0.9712 & 0.0330 \\
(2.2143 e-03) & (1.8950 e-04) & (4.3395 e-03) \\
0.0054 & 0.0262 & 0.9620 \\
\end{array}$ \\
\hline
\end{tabular}

(b) Equally-weighted constructed commodity indices with WTI.

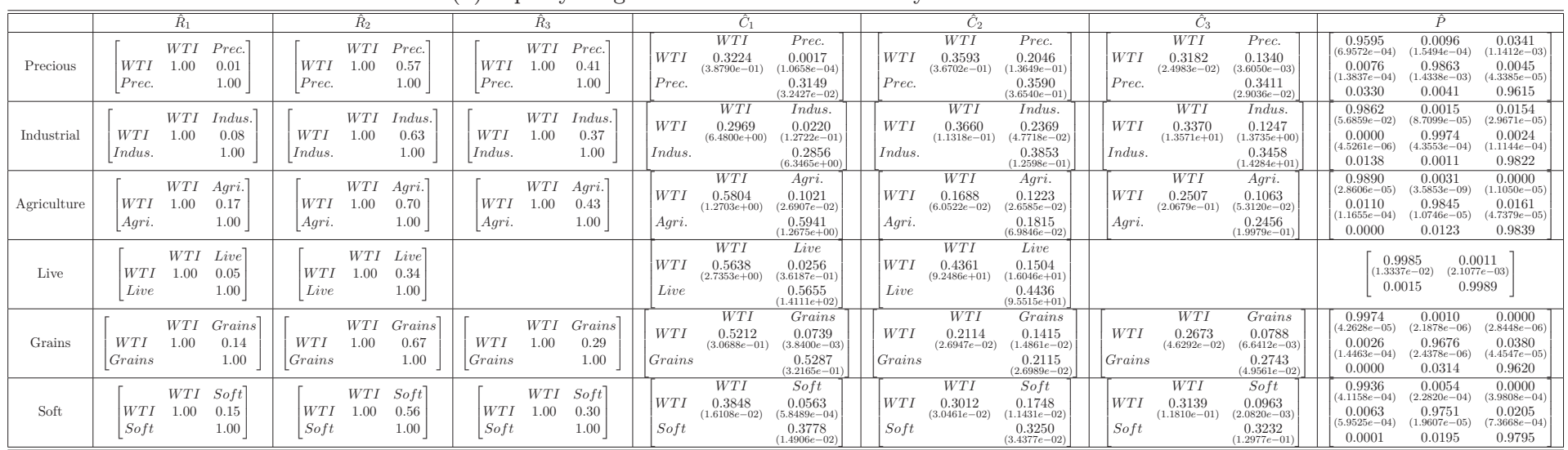

(c) Constructed commodity indices, using GSCI weights, with WTI. 
Table 7: Bivariate commo with WTI.

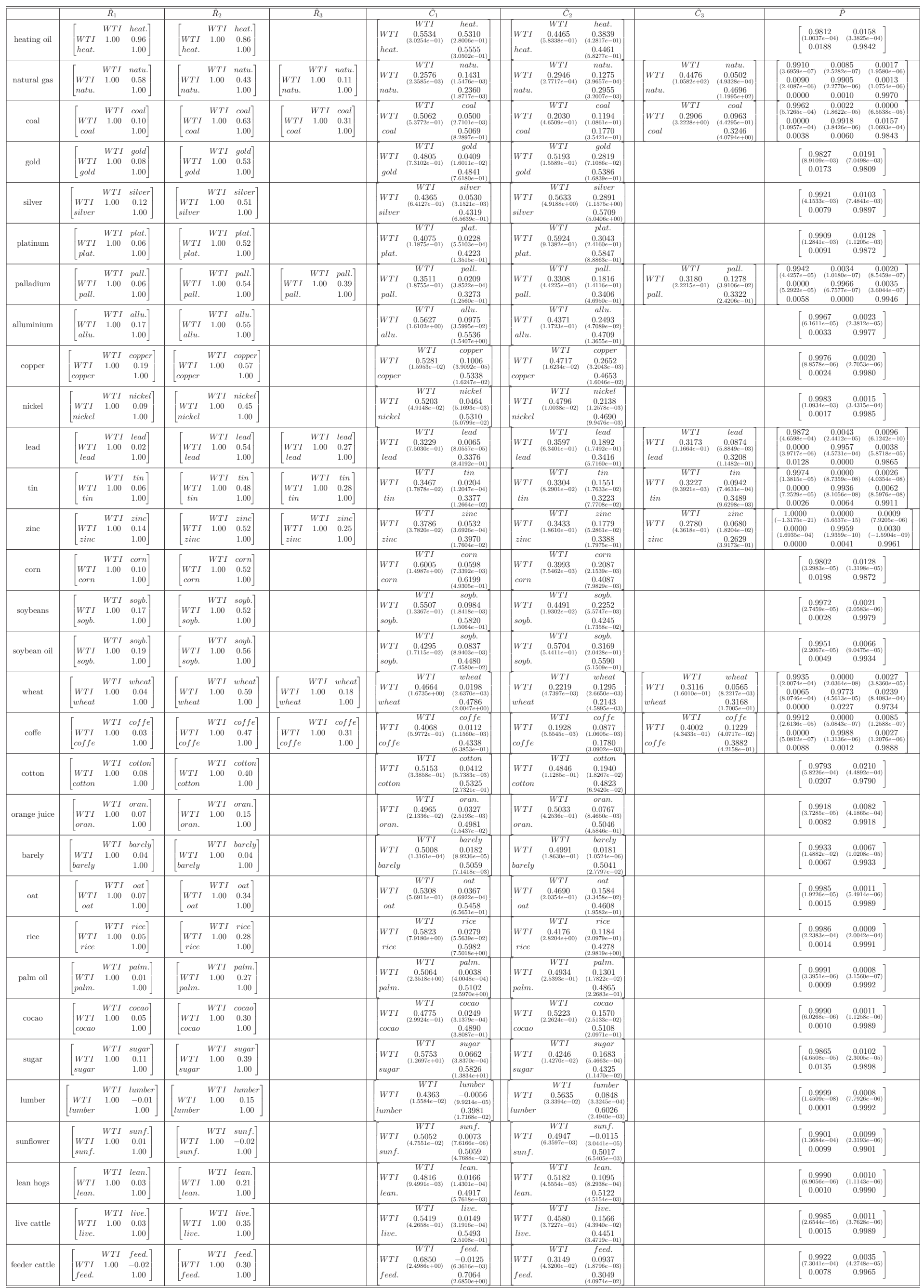


Table 8: Co-movements between commodities and the S\&P500.

\begin{tabular}{|c|c|c|c|c|c|c|c|c|c|c|c|c|c|c|}
\hline & \multicolumn{3}{|c|}{$\dot{R}_{1}$} & \multicolumn{3}{|c|}{$\begin{array}{l}\bar{R}_{2} \\
\end{array}$} & \multicolumn{3}{|c|}{$\begin{array}{l}\hat{C}_{1} \\
\end{array}$} & \multicolumn{3}{|c|}{$\begin{array}{ll}\hat{C}_{2} \\
\end{array}$} & \multicolumn{2}{|c|}{ 芦 } \\
\hline DJUBS & {$\left[\begin{array}{c}\text { DJUBS } \\
\text { SP500 }\end{array}\right.$} & $\begin{array}{c}\text { DJUBS } \\
1.00\end{array}$ & $\left.\begin{array}{cc}S & S P 500 \\
0.02 \\
1.00\end{array}\right]$ & $\begin{array}{c}D J U B S \\
S P 500\end{array}$ & $\begin{array}{c}D J U B S \\
1.00\end{array}$ & $\left.\begin{array}{cc}S & S P 500 \\
0.51 \\
\\
1.00\end{array}\right]$ & $\begin{array}{c}\text { DJUBS } \\
\text { SP500 }\end{array}$ & $\begin{array}{c}\text { DJUBS } \\
0.5686 \\
(9.8428 e-02) \\
\end{array}$ & $\begin{array}{c}S P 500 \\
0.0085 \\
(1.1 .1421 e-05) \\
0.5569 \\
(8.25676-02)\end{array}$ & $\begin{array}{c}D J U B S \\
S P 500\end{array}$ & $\begin{array}{c}\text { DJUBS } \\
0.4414 \\
(6.1621 e-03)\end{array}$ & $\begin{array}{c}S P 500 \\
0.2239 \\
(1.02599-03) \\
0.4349 \\
(5.9932 e-03)\end{array}$ & {$\left[\begin{array}{c}0.9991 \\
(1.3993-06) \\
0.0009\end{array}\right.$} & $\left.\begin{array}{c}0.0007 \\
(2.3559 e-06) \\
0.9993\end{array}\right]$ \\
\hline GSCI & $\begin{array}{l}\text { GSCI } \\
\text { SP500 }\end{array}$ & $\begin{array}{l}\text { GSCI } \\
1.00\end{array}$ & $\left.\begin{array}{c}S P 500 \\
-0.04 \\
1.00\end{array}\right]$ & $\begin{array}{l}\text { GSCI } \\
\text { SP500 }\end{array}$ & $\begin{array}{c}G S C I \\
1.00\end{array}$ & $\left.\begin{array}{c}S P 500 \\
0.57 \\
1.00\end{array}\right]$ & $\begin{array}{l}G S C I \\
S P 500\end{array}$ & $\begin{array}{c}G S C I \\
0.5532 \\
(1.1356 e-01) \\
\end{array}$ & $\begin{array}{c}S P 500 \\
-0.0210 \\
(8.2986 e-05) \\
0.55252 \\
(1.0413 e-01)\end{array}$ & $\begin{array}{l}G S C I \\
S P 500\end{array}$ & $\begin{array}{c}G S C I \\
0.4423 \\
(1.0234 e-02)\end{array}$ & $\left.\begin{array}{c}S P 500 \\
0.253 \\
(5.383232 e-03) \\
0.467 \\
(1.04266-02)\end{array}\right]$ & {$\left[\begin{array}{c}0.9975 \\
(2.80210-04) \\
0.0025\end{array}\right.$} & $\left.\begin{array}{c}0.0022 \\
(1.27444-05) \\
0.9978\end{array}\right]$ \\
\hline RICI & $\begin{array}{l}\text { RICI } \\
\text { SP500 }\end{array}$ & $\begin{array}{l}R I C I \\
1.00\end{array}$ & $\left.\begin{array}{c}S P 500 \\
0.01 \\
1.00\end{array}\right]$ & $\begin{array}{l}R I C I \\
S P 500\end{array}$ & $\begin{array}{c}\text { RICI } \\
1.00\end{array}$ & $\left.\begin{array}{c}S P 500 \\
0.58 \\
1.00\end{array}\right]$ & $\begin{array}{l}R I C I \\
S P 500\end{array}$ & $\begin{array}{c}R I C I \\
0.5587 \\
(9.5770 e-01)\end{array}$ & $\begin{array}{c}S P 500 \\
0.0047 \\
(1.6414 t-04) \\
0.569 \\
(8.6966-0161)\end{array}$ & $\begin{array}{l}R I C I \\
S P 500\end{array}$ & $\begin{array}{c}R I C I \\
0.4326 \\
(9.2056 e-02)\end{array}$ & $\begin{array}{c}S P 500 \\
0.2486 \\
(3.453 e-02) \\
0.4249 \\
(8.878-02\end{array}$ & {$\left[\begin{array}{c}0.9982 \\
(2.01676-05) \\
0.0018\end{array}\right.$} & $\left.\begin{array}{c}0.0014 \\
(2.736330-06) \\
0.9986\end{array}\right]$ \\
\hline CRB & $\begin{array}{l}C R B \\
S P 500\end{array}$ & $\begin{array}{c}C R B \\
1.00\end{array}$ & $\left.\begin{array}{c}S P 500 \\
0.01 \\
1.00\end{array}\right]$ & $\begin{array}{c}C R B \\
S P 500\end{array}$ & $\begin{array}{c}C R B \\
1.00\end{array}$ & $\left.\begin{array}{c}S P 500 \\
0.57 \\
1.00\end{array}\right]$ & $\begin{array}{l}C R B \\
S P 500\end{array}$ & $\begin{array}{c}C R B \\
\left(\begin{array}{c}0.5581 \\
(7.3351 e-01)\end{array}\right.\end{array}$ & 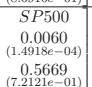 & $\begin{array}{l}C R B \\
S P 500\end{array}$ & $\begin{array}{c}C R B \\
0.4340 \\
(1.0507 e-02)\end{array}$ & $\begin{array}{c}S P 500 \\
0.2466 \\
(4.4268<-03) \\
0.4249 \\
(1.02860-02)\end{array}$ & {$\left[\begin{array}{c}0.9982 \\
(3.7387 e-05) \\
0.0018\end{array}\right.$} & $\left.\begin{array}{c}0.0013 \\
(1.9314 e-06) \\
0.9987\end{array}\right]$ \\
\hline
\end{tabular}

(a) Commodity indices with the S\&P500.

\begin{tabular}{|c|c|c|c|c|c|c|c|c|c|c|c|c|c|c|}
\hline & \multicolumn{3}{|c|}{$\bar{R}_{1}$} & \multicolumn{3}{|c|}{$\hat{R}_{2}$} & \multicolumn{3}{|c|}{$\hat{C}_{1}$} & \multicolumn{3}{|c|}{$\hat{C}_{2}$} & \multicolumn{2}{|c|}{ 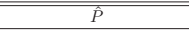 } \\
\hline Energy & {$\left[\begin{array}{l}\text { SP500 } \\
\text { Energy }\end{array}\right.$} & $\begin{array}{l}S P 500 \\
1.00\end{array}$ & $\left.\begin{array}{c}\text { Energy } \\
-0.04 \\
1.00\end{array}\right]$ & $\begin{array}{l}\text { SP500 } \\
\text { Energy }\end{array}$ & $\begin{array}{c}S P 500 \\
1.00\end{array}$ & $\left.\begin{array}{c}\text { Energy } \\
0.50 \\
1.00\end{array}\right]$ & $\begin{array}{l}\text { SP500 } \\
\text { Energy }\end{array}$ & $\begin{array}{c}S P 500 \\
0.5722 \\
(5.0667 e-02) \\
\end{array}$ & $\begin{array}{c}\text { Energy } \\
-0.0230 \\
(2.80181 e-04 \\
0.553 \\
(5.43212-02\end{array}$ & $\begin{array}{l}\text { SP500 } \\
\text { Energy }\end{array}$ & $\begin{array}{c}S P 500 \\
0.4197 \\
(2.2551 e-02) \\
\end{array}$ & $\begin{array}{c}\text { Energy } \\
0.2099 \\
(3.9519-03) \\
0.4129 \\
(2.2025-02)\end{array}$ & {$\left[\begin{array}{c}0.9979 \\
(1.5632 e-04) \\
0.0021\end{array}\right.$} & $\left.\begin{array}{c}0.0015 \\
(1.52577-0.5) \\
0.9985\end{array}\right]$ \\
\hline Precious & $\begin{array}{c}\text { SP500 } \\
\text { Prec. }\end{array}$ & $\begin{array}{c}S P 500 \\
1.00\end{array}$ & $\left.\begin{array}{c}\text { Prec. } \\
-0.09 \\
1.00\end{array}\right]$ & $\begin{array}{l}\text { SP500 } \\
\text { Prec. }\end{array}$ & $\begin{array}{l}S P 500 \\
1.00\end{array}$ & $\left.\begin{array}{c}\text { Prec. } \\
0.42 \\
1.00\end{array}\right]$ & $\begin{array}{l}\text { SP500 } \\
\text { Prec. }\end{array}$ & $\begin{array}{c}S P 500 \\
0.5981 \\
(1.1156 e+00) \\
\end{array}$ & $\begin{array}{c}\text { Prec. } \\
-0.054 \\
(4.16310-0.03) \\
0.5866 \\
(1.06986+00)\end{array}$ & $\begin{array}{l}\text { SP500 } \\
\text { Prec. }\end{array}$ & $\begin{array}{c}S P 500 \\
0.3937 \\
(2.0030 e-01) \\
\end{array}$ & $\begin{array}{c}\text { Prec. } \\
0.1731 \\
(3.14877-02) \\
0.4380 \\
(2.4522 e-01)\end{array}$ & {$\left[\begin{array}{c}0.9759 \\
(1.302920-03) \\
0.0241\end{array}\right.$} & $\left.\begin{array}{c}0.0186 \\
(1.78838-04) \\
0.9814\end{array}\right]$ \\
\hline Industrial & $\begin{array}{l}\text { SP500 } \\
\text { Indus. }\end{array}$ & $\begin{array}{l}S P 500 \\
1.00\end{array}$ & $\left.\begin{array}{c}\text { Indus. } \\
0.15 \\
1.00\end{array}\right]$ & {$\left[\begin{array}{l}\text { SP500 } \\
\text { Indus. }\end{array}\right.$} & $\begin{array}{c}S P 500 \\
1.00\end{array}$ & $\left.\begin{array}{c}\text { Indus. } \\
0.49 \\
1.00\end{array}\right]$ & $\begin{array}{l}\text { SP500 } \\
\text { Indus. }\end{array}$ & $\begin{array}{c}\text { SP500 } \\
0.6411 \\
(1.9335 e-02) \\
\end{array}$ & $\begin{array}{c}\text { Indus. } \\
0.0973 \\
(7.7 .73037-05) \\
0.6453 \\
(2.03385-02)\end{array}$ & $\begin{array}{l}\text { SP500 } \\
\text { Indus. }\end{array}$ & $\begin{array}{c}S P 500 \\
0.3507 \\
(3.7462 e-04)\end{array}$ & $\begin{array}{c}\text { Indus. } \\
0.1756 \\
(9.71056-05) \\
0.3629 \\
(3.9687 e-04)\end{array}$ & {$\left[\begin{array}{c}0.9989 \\
(2.18880-06) \\
0.0011\end{array}\right.$} & $\left.\begin{array}{c}0.0006 \\
(1.91744-07) \\
0.9994\end{array}\right]$ \\
\hline Agriculture & $\begin{array}{l}\text { SP500 } \\
\text { Agri. }\end{array}$ & $\begin{array}{c}S P 500 \\
1.00\end{array}$ & $\left.\begin{array}{c}\text { Agri. } \\
0.06 \\
1.00\end{array}\right]$ & {$\left[\begin{array}{l}\text { SP500 } \\
\text { Agri. }\end{array}\right.$} & $\begin{array}{c}S P 500 \\
1.00\end{array}$ & $\left.\begin{array}{c}\text { Agri. } \\
0.44 \\
1.00\end{array}\right]$ & $\begin{array}{l}\text { SP500 } \\
\text { Agri. }\end{array}$ & $\begin{array}{c}S P 500 \\
0.6271 \\
(2.1173 e-02)\end{array}$ & $\begin{array}{c}\text { Agri. } \\
0.0370 \\
(1.5310-04) \\
0.6286 \\
(2.1277 e-02)\end{array}$ & $\begin{array}{l}\text { SP500 } \\
\text { Agri. }\end{array}$ & $\begin{array}{c}S P 500 \\
0.3648 \\
(2.4110 e-02)\end{array}$ & $\begin{array}{c}\text { Agr } \\
0.168 \\
(4.3489 e \\
0.401 \\
(2.9118 e\end{array}$ & {$\left[\begin{array}{c}0.9988 \\
(5.82942-06) \\
0.0012\end{array}\right.$} & $\left.\begin{array}{c}0.0006 \\
(1.181515-07) \\
0.9994\end{array}\right]$ \\
\hline Live & $\begin{array}{c}\text { SP500 } \\
\text { Live }\end{array}$ & $\begin{array}{c}S P 500 \\
1.00\end{array}$ & $\left.\begin{array}{c}\text { Live } \\
-0.04 \\
1.00\end{array}\right]$ & $\begin{array}{c}\text { SP500 } \\
\text { Live }\end{array}$ & $\begin{array}{c}\text { SP500 } \\
1.00\end{array}$ & $\left.\begin{array}{l}\text { Live } \\
0.27 \\
1.00\end{array}\right]$ & $\begin{array}{c}\text { SP500 } \\
\text { Live }\end{array}$ & $\begin{array}{c}S P 500 \\
0.5772 \\
(9.1244 e-03) \\
\end{array}$ & $\begin{array}{c}\text { Live } \\
-0.0212 \\
(3.5065-04) \\
0.5727 \\
(7.9026-03)\end{array}$ & $\begin{array}{c}\text { SP500 } \\
\text { Live }\end{array}$ & $\begin{array}{c}S P 500 \\
0.4146 \\
(2.2298 e-02)\end{array}$ & $\begin{array}{c}\text { Live } \\
0.11118 \\
(1.42066-03) \\
0.4205 \\
(2.2741 e-02)\end{array}$ & {$\left[\begin{array}{c}0.9988 \\
(5.23877-077) \\
0.0012\end{array}\right.$} & {$\left[\begin{array}{c}0.0014 \\
(2.4206-06) \\
0.9986\end{array}\right]$} \\
\hline Grains & $\begin{array}{l}\text { SP500 } \\
\text { Grains }\end{array}$ & $\begin{array}{l}S P 500 \\
1.00\end{array}$ & $\left.\begin{array}{c}\text { Grains } \\
0.03 \\
1.00\end{array}\right]$ & {$\left[\begin{array}{l}\text { SP500 } \\
\text { Grains }\end{array}\right.$} & $\begin{array}{c}S P 500 \\
1.00\end{array}$ & $\left.\begin{array}{c}\text { Grains } \\
0.34 \\
1.00\end{array}\right]$ & $\begin{array}{l}\text { SP500 } \\
\text { Grains }\end{array}$ & $\begin{array}{c}\text { SP500 } \\
0.6558 \\
(4.1414 e-02) \\
\end{array}$ & $\begin{array}{c}\text { Grains } \\
0.0216 \\
(1.4383 e-04 \\
0.6741 \\
(4.2127 e-02 \\
\end{array}$ & $\begin{array}{l}\text { SP500 } \\
\text { Grains }\end{array}$ & $\begin{array}{c}S P 500 \\
0.3360 \\
(8.02022-03)\end{array}$ & $\begin{array}{c}\text { Grains } \\
0.1154 \\
(4.2015-04) \\
0.3397 \\
(8.5673 e-03)\end{array}$ & {$\left[\begin{array}{c}0.9988 \\
(1.937110-05) \\
0.0012\end{array}\right.$} & $\left.\begin{array}{c}0.0006 \\
(3.2971 e-07) \\
0.9994\end{array}\right]$ \\
\hline Soft & $\begin{array}{l}\text { SP500 } \\
\text { Soft }\end{array}$ & $\begin{array}{c}S P 500 \\
1.00\end{array}$ & $\left.\begin{array}{l}\text { Soft } \\
0.05 \\
1.00\end{array}\right]$ & $\begin{array}{l}\text { SP500 } \\
\text { Soft }\end{array}$ & $\begin{array}{c}\text { SP500 } \\
1.00\end{array}$ & $\left.\begin{array}{c}\text { Soft } \\
0.41 \\
1.00\end{array}\right]$ & $\begin{array}{c}\text { SP500 } \\
\text { Soft }\end{array}$ & $\begin{array}{c}S P 500 \\
0.5544 \\
(3.6586 e-02)\end{array}$ & $\begin{array}{c}\text { Soft } \\
0.0270 \\
(5.55382 e-04) \\
0.5636 \\
(4.3601 e-02)\end{array}$ & $\begin{array}{c}\text { SP500 } \\
\text { Soft }\end{array}$ & $\begin{array}{c}\text { SP500 } \\
0.4374 \\
(3.9317 e-02)\end{array}$ & 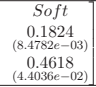 & {$\left[\begin{array}{c}0.9987 \\
(8.5140 e-07) \\
0.0013\end{array}\right.$} & $\left.\begin{array}{c}0.0007 \\
(2.7647 e-07) \\
0.9993\end{array}\right]$ \\
\hline
\end{tabular}

(b) Equally-weighted constructed commodity indices with S\&P500.

\begin{tabular}{|c|c|c|c|c|c|c|c|c|c|c|c|c|c|c|}
\hline & \multicolumn{3}{|c|}{$\hat{R}_{1}$} & \multicolumn{3}{|c|}{$\hat{R}_{2}$} & \multicolumn{3}{|c|}{$\hat{C}_{1}$} & \multicolumn{3}{|c|}{$\hat{C}_{2}$} & \multicolumn{2}{|c|}{$\overline{\bar{P}}$} \\
\hline Energy & $\begin{array}{l}\text { SP500 } \\
\text { Energy }\end{array}$ & $\begin{array}{c}S P 500 \\
1.00\end{array}$ & $\left.\begin{array}{c}\text { Energy } \\
-0.03 \\
1.00\end{array}\right]$ & {$\left[\begin{array}{l}\text { SP500 } \\
\text { Energy }\end{array}\right.$} & $\begin{array}{c}\text { SP500 } \\
1.00\end{array}$ & $\left.\begin{array}{c}\text { Energy } \\
0.57 \\
1.00\end{array}\right]$ & $\begin{array}{l}\text { SP500 } \\
\text { Energy }\end{array}$ & $\begin{array}{c}S P 500 \\
0.5655 \\
(1.0123 e-01) \\
\end{array}$ & $\begin{array}{c}\text { Energy } \\
-0.0194 \\
(1.72019-03) \\
0.5622 \\
(1.25272-01\end{array}$ & $\begin{array}{l}\text { SP500 } \\
\text { Energy }\end{array}$ & $\begin{array}{c}\text { SP500 } \\
0.4263 \\
(3.3212 e-01)\end{array}$ & $\begin{array}{c}\text { Enorgy } \\
0.2460 \\
(9.5973-02) \\
0.4339 \\
(3.4464-01\end{array}$ & {$\left[\begin{array}{c}0.9980 \\
(1.91460-03) \\
0.0020\end{array}\right.$} & $\left.\begin{array}{c}0.0016 \\
(1.87732-04) \\
0.9984\end{array}\right]$ \\
\hline Precious & $\begin{array}{l}\text { SP500 } \\
\text { Prec. }\end{array}$ & $\begin{array}{c}\text { SP500 } \\
1.00\end{array}$ & $\left.\begin{array}{c}\text { Prec. } \\
-0.14 \\
1.00\end{array}\right]$ & $\begin{array}{l}\text { SP500 } \\
\text { Prec. }\end{array}$ & $\begin{array}{c}S P 500 \\
1.00\end{array}$ & $\left.\begin{array}{c}\text { Prec. } \\
0.40 \\
1.00\end{array}\right]$ & $\begin{array}{l}\text { SP500 } \\
\text { Prec. }\end{array}$ & $\begin{array}{c}S P 500 \\
0.6034 \\
(4.7433 e+00) \\
\end{array}$ & $\begin{array}{c}\text { Prec. } \\
-0.0813 \\
(7.7 .7275-02) \\
0.5809 \\
(4.37070+00)\end{array}$ & $\begin{array}{c}\text { SP500 } \\
\text { Prec. }\end{array}$ & $\begin{array}{c}S P 500 \\
0.3855 \\
(2.2603 e-01)\end{array}$ & $\begin{array}{c}\text { Prec. } \\
0.1644 \\
(2.2007 \overline{2}-02) \\
0.4341 \\
(2.7992 e-01)\end{array}$ & {$\left[\begin{array}{c}0.9750 \\
(3.14880-03) \\
0.0250\end{array}\right.$} & $\left.\begin{array}{c}0.0194 \\
(4.96329-04) \\
0.9806\end{array}\right]$ \\
\hline Industrial & {$\left[\begin{array}{l}\text { SP500 } \\
\text { Indus. }\end{array}\right.$} & $\begin{array}{c}S P 500 \\
1.00\end{array}$ & $\left.\begin{array}{c}\text { Indus. } \\
0.15 \\
1.00\end{array}\right]$ & {$\left[\begin{array}{l}\text { SP500 } \\
\text { Indus. }\end{array}\right.$} & $\begin{array}{c}S P 500 \\
1.00\end{array}$ & $\left.\begin{array}{c}\text { Indus. } \\
0.50 \\
1.00\end{array}\right]$ & $\begin{array}{l}\text { SP500 } \\
\text { Indus. }\end{array}$ & $\begin{array}{c}S P 500 \\
0.6387 \\
(4.9060 e-01)\end{array}$ & $\begin{array}{c}\text { Indus. } \\
0.0962 \\
(9.6883 e-03) \\
0.6464 \\
(5.1523 e-01)\end{array}$ & $\begin{array}{l}\text { SP500 } \\
\text { Indus. }\end{array}$ & $\begin{array}{c}S P 500 \\
0.3531 \\
(1.1295 e-01)\end{array}$ & $\begin{array}{c}\text { Indus. } \\
0.1825 \\
(3.1180-02) \\
0.3702 \\
(1.1853 e-01)\end{array}$ & {$\left[\begin{array}{c}0.9989 \\
(1.57370-06) \\
0.0011\end{array}\right.$} & $\left.\begin{array}{c}0.0007 \\
(1.3788 e-07) \\
0.9993\end{array}\right]$ \\
\hline Agriculture & $\begin{array}{l}\text { SP500 } \\
\text { Agri. }\end{array}$ & $\begin{array}{c}S P 500 \\
1.00\end{array}$ & $\left.\begin{array}{c}\text { Agri. } \\
0.04 \\
1.00\end{array}\right]$ & $\begin{array}{l}\text { SP500 } \\
\text { Agri. }\end{array}$ & $\begin{array}{c}S P 500 \\
1.00\end{array}$ & $\left.\begin{array}{r}\text { Agri. } \\
0.38 \\
1.00\end{array}\right]$ & $\begin{array}{l}\text { SP500 } \\
\text { Agri. }\end{array}$ & $\begin{array}{c}S P 500 \\
0.6467 \\
(6.4541 e-01)\end{array}$ & $\begin{array}{c}\text { Agri. } \\
0.0227 \\
(1.16182 e-03) \\
0.6453 \\
(6.3884 e-01)\end{array}$ & $\begin{array}{c}\text { SP500 } \\
\text { Agri. }\end{array}$ & $\begin{array}{c}S P 500 \\
0.341 \\
(1.8756 e-02)\end{array}$ & $\begin{array}{c}\text { Agri. } \\
0.1352 \\
(3.3552 e-03) \\
0.3760 \\
(2.1877 e-02)\end{array}$ & {$\left[\begin{array}{c}0.9988 \\
(5.738480-06) \\
0.0012\end{array}\right.$} & $\left.\begin{array}{c}0.0006 \\
(3.79549-07) \\
0.9994\end{array}\right]$ \\
\hline Live & $\begin{array}{c}S P 500 \\
\text { Live }\end{array}$ & $\begin{array}{c}\text { SP500 } \\
1.00\end{array}$ & $\left.\begin{array}{c}\text { Live } \\
-0.03 \\
1.00\end{array}\right]$ & $\begin{array}{c}\text { SP500 } \\
\text { Live }\end{array}$ & $\begin{array}{c}S P 500 \\
1.00\end{array}$ & $\left.\begin{array}{c}\text { Live } \\
0.27 \\
1.00\end{array}\right]$ & $\begin{array}{c}S P 500 \\
\text { Live }\end{array}$ & $\begin{array}{c}S P 500 \\
0.5652 \\
(1.1875 e-02) \\
\end{array}$ & $\begin{array}{c}\text { Live } \\
-0.0197 \\
(2.7522 e-04) \\
0.5748 \\
(2.8320 e-00)\end{array}$ & $\begin{array}{c}\text { SP500 } \\
\text { Live }\end{array}$ & $\begin{array}{c}S P 500 \\
0.4266 \\
(2.6173 e-02)\end{array}$ & $\begin{array}{c}\text { Live } \\
0.1176 \\
(2.07911 e-03) \\
0.4343 \\
(2.9666 e-02)\end{array}$ & {$\left[\begin{array}{c}0.9988 \\
(5.491110-077) \\
0.0012\end{array}\right.$} & $\left.\begin{array}{c}0.0014 \\
(2.42549-06) \\
0.9986\end{array}\right]$ \\
\hline Grains & $\begin{array}{l}\text { SP500 } \\
\text { Grains }\end{array}$ & $\begin{array}{c}S P 500 \\
1.00\end{array}$ & $\left.\begin{array}{c}\text { Grains } \\
0.03 \\
1.00\end{array}\right]$ & {$\left[\begin{array}{l}\text { SP500 } \\
\text { Grains }\end{array}\right.$} & $\begin{array}{c}S P 500 \\
1.00\end{array}$ & $\left.\begin{array}{c}\text { Grains } \\
0.34 \\
1.00\end{array}\right]$ & $\begin{array}{l}\text { SP500 } \\
\text { Grains }\end{array}$ & $\begin{array}{c}S P 500 \\
0.6635 \\
(1.1279 e-01)\end{array}$ & $\begin{array}{c}\text { Grains } \\
0.0177 \\
(1.46100-04) \\
0.6651 \\
(1.1677 e-011)\end{array}$ & $\begin{array}{l}\text { SP500 } \\
\text { Grains }\end{array}$ & $\begin{array}{c}S P 500 \\
0.3284 \\
(5.9472 e-03)\end{array}$ & $\begin{array}{c}\text { Grains } \\
0.1150 \\
(1.2940 e-03) \\
0.3494 \\
(7.06060-033)\end{array}$ & {$\left[\begin{array}{c}0.9986 \\
(1.94750-05) \\
0.0014\end{array}\right.$} & $\left.\begin{array}{c}0.0006 \\
(5.4345 e-07) \\
0.9994\end{array}\right]$ \\
\hline Soft & $\begin{array}{c}\text { SP500 } \\
\text { Soft }\end{array}$ & $\begin{array}{c}S P 500 \\
1.00\end{array}$ & $\left.\begin{array}{l}\text { Soft } \\
0.03 \\
1.00\end{array}\right]$ & $\begin{array}{c}\text { SP500 } \\
\text { Soft }\end{array}$ & $\begin{array}{c}S P 500 \\
1.00\end{array}$ & $\left.\begin{array}{c}\text { Soft } \\
0.39 \\
1.00\end{array}\right]$ & $\begin{array}{l}\text { SP500 } \\
\text { Soft }\end{array}$ & $\begin{array}{c}S P 500 \\
0.5418 \\
(1.2002 e-01)\end{array}$ & $\begin{array}{c}\text { Soft } \\
0.0183 \\
(2.13972-05) \\
0.5567 \\
(9.0162 e-02)\end{array}$ & $\begin{array}{c}\text { SP500 } \\
\text { Soft }\end{array}$ & $\begin{array}{c}S P 500 \\
0.4500 \\
(5.63090-02)\end{array}$ & $\begin{array}{c}\text { Soft } \\
0.1777 \\
(8.3910 e-03) \\
0.4693 \\
(6.2509 e-02)\end{array}$ & {$\left[\begin{array}{c}0.9988 \\
(1.7024-060) \\
0.0012\end{array}\right.$} & $\left.\begin{array}{c}0.0007 \\
(1.4017 e-07) \\
0.9993\end{array}\right]$ \\
\hline
\end{tabular}

(c) Constructed commodity indices, using GSCI weights, with S\&P500. 
Table 9: Bivariate commodity-equity estimations.

\begin{tabular}{|c|c|c|c|c|c|c|c|c|c|c|c|c|c|c|}
\hline & \multicolumn{3}{|c|}{$\overline{\hat{R}_{1}}$} & \multicolumn{3}{|c|}{$\overline{\hat{R}_{2}}$} & \multicolumn{3}{|c|}{$\hat{C}_{1}$} & \multicolumn{3}{|c|}{$\begin{array}{ll}\hat{C}_{2} \\
\end{array}$} & \multicolumn{2}{|r|}{$\hat{\bar{P}}$} \\
\hline wti & $\begin{array}{c}S P 500 \\
w t i\end{array}$ & $\begin{array}{l}\text { SP500 } \\
1.00\end{array}$ & $\left.\begin{array}{c}w t i \\
-0.06 \\
1.00\end{array}\right]$ & $\begin{array}{c}S P 500 \\
w t i\end{array}$ & $\begin{array}{c}S P 500 \\
1.00\end{array}$ & $\left.\begin{array}{c}w t i \\
0.56 \\
1.00\end{array}\right]$ & $\begin{array}{c}S P 500 \\
w t i\end{array}$ & $\begin{array}{c}S P 500 \\
0.5281 \\
(9.3179 e+01)\end{array}$ & $\begin{array}{c}w t i \\
-0.0333 \\
(3.2084-0.01) \\
(9.548483 \\
(9.7807+01)\end{array}$ & $\begin{array}{c}S P 500 \\
w t i\end{array}$ & $\begin{array}{c}S P 500 \\
0.4638 \\
(2.7615 e+00)\end{array}$ & $\begin{array}{c}w t i \\
0.2582 \\
(2.5575-011) \\
0.4516 \\
(2.64899+00)\end{array}$ & {$\left[\begin{array}{c}0.9972 \\
(6.4572 e-01) \\
0.0028\end{array}\right.$} & {$\left[\begin{array}{c}0.0027 \\
(9.4933 e-02) \\
0.9973\end{array}\right]$} \\
\hline heating oil & {$\left[\begin{array}{l}\text { SP500 } \\
\text { heat. }\end{array}\right.$} & $\begin{array}{c}S P 500 \\
1.00\end{array}$ & $\left.\begin{array}{c}\text { heat. } \\
-0.07 \\
1.00\end{array}\right]$ & {$\left[\begin{array}{l}\text { SP500 } \\
\text { heat. }\end{array}\right.$} & $\begin{array}{c}S P 500 \\
1.00\end{array}$ & $\left.\begin{array}{r}\text { heat. } \\
0.52 \\
1.00\end{array}\right]$ & $\begin{array}{l}\text { SP500 } \\
\text { heat. }\end{array}$ & $\begin{array}{c}S P 500 \\
0.5350 \\
(1.0234 e+00)\end{array}$ & 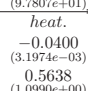 & $\begin{array}{l}\text { SP500 } \\
\text { heat. }\end{array}$ & $\begin{array}{c}S P 500 \\
0.4569 \\
(1.77000-02)\end{array}$ & $\begin{array}{c}(2.6889 e++00) \\
\text { heat. } \\
0.2345 \\
(5.60466-03) \\
0.4378\end{array}$ & {$\left[\begin{array}{c}0.9973 \\
(9.2520 e-03) \\
0.0027\end{array}\right.$} & $\left.\begin{array}{c}0.0025 \\
(4.0007 e-04) \\
0.9975\end{array}\right]$ \\
\hline natural gas & {$\left[\begin{array}{l}\text { SP500 } \\
\text { natu. }\end{array}\right.$} & $\begin{array}{c}S P 500 \\
1.00\end{array}$ & $\left.\begin{array}{c}\text { natu. } \\
-0.02 \\
1.00\end{array}\right]$ & {$\left[\begin{array}{l}\text { SP500 } \\
\text { natu. }\end{array}\right.$} & $\begin{array}{c}S P 500 \\
1.00\end{array}$ & $\left.\begin{array}{c}\text { natu. } \\
0.11 \\
1.00\end{array}\right]$ & $\begin{array}{l}\text { SP500 } \\
\text { natu. }\end{array}$ & $\begin{array}{c}S P 500 \\
0.4897 \\
(3.8346 e-02) \\
\end{array}$ & $\begin{array}{c}\text { natu. } \\
-0.0100 \\
(3.0417-04) \\
0.4990 \\
(3.2980-02)\end{array}$ & $\begin{array}{l}\text { SP500 } \\
\text { natu. }\end{array}$ & $\begin{array}{c}S P 500 \\
0.5021 \\
(1.5905 e-02) \\
\end{array}$ & $\begin{array}{c}n \text { natu. } \\
0.0552 \\
(1.1734-03) \\
0.5021 \\
(13644-022\end{array}$ & {$\left[\begin{array}{c}0.9976 \\
(3.3560 e-04) \\
0.0024\end{array}\right.$} & $\left.\begin{array}{c}0.0022 \\
(1.8069 e-04) \\
0.9978\end{array}\right]$ \\
\hline coal & {$\left[\begin{array}{c}S P 500 \\
\text { coal }\end{array}\right.$} & $\begin{array}{l}S P 500 \\
1.00\end{array}$ & $\left.\begin{array}{c}c o a l \\
-0.03 \\
1.00\end{array}\right]$ & $\begin{array}{c}S P 500 \\
\text { coal }\end{array}$ & $\begin{array}{c}S P 500 \\
1.00\end{array}$ & $\left.\begin{array}{c}c o a l \\
0.34 \\
1.00\end{array}\right]$ & $\begin{array}{c}S P 500 \\
\text { coal }\end{array}$ & $\begin{array}{c}S P 500 \\
0.6410 \\
(6.9090 e-02)\end{array}$ & $\begin{array}{c}c \text { coal } \\
-0.0184 \\
(3.57212-0.04) \\
0.6551 \\
(6.0670-021\end{array}$ & $\begin{array}{l}\text { SP500 } \\
\text { coal }\end{array}$ & $\begin{array}{c}S P 500 \\
0.3558 \\
(1.4348 e-04)\end{array}$ & $\begin{array}{c}\text { coal } \\
0.1187 \\
(1.00860-04) \\
0.3534 \\
(1.6080-04)\end{array}$ & {$\left[\begin{array}{c}0.9971 \\
(8.74440-06) \\
0.0029\end{array}\right.$} & $\left.\begin{array}{c}0.0014 \\
(5.4562-077) \\
0.9986\end{array}\right]$ \\
\hline gold & {$\left[\begin{array}{c}\text { SP500 } \\
\text { gold }\end{array}\right.$} & $\begin{array}{l}S P 500 \\
1.00\end{array}$ & $\left.\begin{array}{c}\text { gold } \\
-0.17 \\
1.00\end{array}\right]$ & {$\left[\begin{array}{l}\text { SP500 } \\
\text { gold }\end{array}\right.$} & $\begin{array}{c}S P 500 \\
1.00\end{array}$ & $\left.\begin{array}{l}\text { gold } \\
0.37 \\
1.00\end{array}\right]$ & $\begin{array}{c}S P 500 \\
\text { gold }\end{array}$ & $\begin{array}{c}S P 500 \\
0.5831 \\
(5.2981 e+00)\end{array}$ & $\begin{array}{c}\text { gold } \\
-0.0984 \\
(1.4930-0.01) \\
0.5735 \\
(5.1244+0)\end{array}$ & $\begin{array}{l}\text { SP500 } \\
\text { gold }\end{array}$ & $\begin{array}{c}S P 500 \\
0.4007 \\
(1.0089 e-01)\end{array}$ & $\begin{array}{c}\text { gold } \\
0.1588 \\
(4.7832-03) \\
0.4492 \\
(1.28030-01)\end{array}$ & {$\left[\begin{array}{c}0.9738 \\
(1.5399 e-03) \\
0.0262\end{array}\right.$} & $\left.\begin{array}{c}0.0220 \\
(2.43280-04) \\
0.9780\end{array}\right]$ \\
\hline silver & $\begin{array}{l}\text { SP500 } \\
\text { silver }\end{array}$ & $\begin{array}{c}S P 500 \\
1.00\end{array}$ & $\left.\begin{array}{c}\text { silver } \\
-0.04 \\
1.00\end{array}\right]$ & {$\left[\begin{array}{l}\text { SP500 } \\
\text { silver }\end{array}\right.$} & $\begin{array}{l}S P 500 \\
1.00\end{array}$ & $\left.\begin{array}{c}\text { silver } \\
0.41 \\
1.00\end{array}\right]$ & $\begin{array}{l}\text { SP500 } \\
\text { silver }\end{array}$ & $\begin{array}{c}S P 500 \\
0.5929 \\
(1.6742 e-01) \\
\end{array}$ & $\begin{array}{c}\text { silver } \\
-0.0245 \\
(7.452-0.05) \\
0.5900 \\
(1.78700 e-01) \\
\end{array}$ & $\begin{array}{l}\text { SP500 } \\
\text { silver }\end{array}$ & $\begin{array}{c}S P 500 \\
0.3989 \\
(5.7527 e-02) \\
\end{array}$ & $\begin{array}{c}\text { silver } \\
0.1656 \\
(7.4681 e-03) \\
0.4128 \\
(6.4255 e-02)\end{array}$ & {$\left[\begin{array}{c}0.9812 \\
(1.106220-04) \\
0.0188\end{array}\right.$} & $\left.\begin{array}{c}0.0143 \\
(2.98568-05) \\
0.9857\end{array}\right]$ \\
\hline platinum & $\begin{array}{l}\text { SP500 } \\
\text { plat. }\end{array}$ & $\begin{array}{c}S P 500 \\
1.00\end{array}$ & $\left.\begin{array}{c}\text { plat. } \\
0.03 \\
1.00\end{array}\right]$ & $\begin{array}{l}\text { SP500 } \\
\text { plat. }\end{array}$ & $\begin{array}{c}S P 500 \\
1.00\end{array}$ & $\left.\begin{array}{c}\text { plat. } \\
0.42 \\
1.00\end{array}\right]$ & $\begin{array}{l}S P 500 \\
\text { plat. }\end{array}$ & $\begin{array}{c}S P 500 \\
0.6176 \\
(1.1949 e+00) \\
\end{array}$ & $\begin{array}{c}\text { plat. } \\
0.0200 \\
(1.1428<-03) \\
0.5990 \\
(1.395 e+00)\end{array}$ & $\begin{array}{l}\text { SP500 } \\
\text { plat. }\end{array}$ & $\begin{array}{c}S P 500 \\
0.3742 \\
(6.3042 e-01)\end{array}$ & $\begin{array}{c}\text { plat. } \\
0.1623 \\
(1.25866-01) \\
0.4080 \\
(7.4456-01)\end{array}$ & {$\left[\begin{array}{c}0.9983 \\
(2.21388-05) \\
0.0017\end{array}\right.$} & $\left.\begin{array}{c}0.0011 \\
(1.7921-05) \\
0.9989\end{array}\right]$ \\
\hline palladium & $\begin{array}{c}\text { SP500 } \\
\text { pall. }\end{array}$ & $\begin{array}{c}S P 500 \\
1.00\end{array}$ & $\left.\begin{array}{c}\text { pall. } \\
0.08 \\
1.00\end{array}\right]$ & $\begin{array}{l}\text { SP500 } \\
\text { pall. }\end{array}$ & $\begin{array}{c}S P 500 \\
1.00\end{array}$ & $\left.\begin{array}{c}\text { pall. } \\
0.45 \\
1.00\end{array}\right]$ & $\begin{array}{l}\text { SP500 } \\
\text { pall. }\end{array}$ & $\begin{array}{c}S P 500 \\
0.6265 \\
(1.6831 e-02) \\
\end{array}$ & $\begin{array}{c}\text { pall. } \\
0.0496 \\
(4.1153 e-05) \\
0.6127 \\
(1.6966-022\end{array}$ & $\begin{array}{l}\text { SP500 } \\
\text { pall. }\end{array}$ & $\begin{array}{c}S P 500 \\
0.3653 \\
(4.3826 e-02) \\
\end{array}$ & $\begin{array}{c}\text { pall. } \\
0.1694 \\
(8.51744-0.03) \\
0.3874 \\
(49233-022\end{array}$ & {$\left[\begin{array}{c}0.9989 \\
(4.8755-06) \\
0.0011\end{array}\right.$} & $\left.\begin{array}{c}0.0006 \\
(1.37599-06) \\
0.9994\end{array}\right]$ \\
\hline alluminium & $\begin{array}{l}\text { SP500 } \\
\text { allu. }\end{array}$ & $\begin{array}{c}S P 500 \\
1.00\end{array}$ & $\left.\begin{array}{c}\text { allu. } \\
0.12 \\
1.00\end{array}\right]$ & {$\left[\begin{array}{c}\text { SP500 } \\
\text { allu. }\end{array}\right.$} & $\begin{array}{c}S P 500 \\
1.00\end{array}$ & $\left.\begin{array}{l}\text { allu. } \\
0.45 \\
1.00\end{array}\right]$ & $\begin{array}{l}\text { SP500 } \\
\text { allu. }\end{array}$ & $\begin{array}{c}S P 500 \\
0.6444 \\
(2.4159 e-01)\end{array}$ & 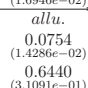 & $\begin{array}{l}\text { SP500 } \\
\text { allu. }\end{array}$ & $\begin{array}{c}S P 500 \\
0.3475 \\
(4.3856 e-01)\end{array}$ & 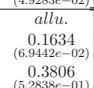 & {$\left[\begin{array}{c}0.9988 \\
(1.7809 e-03) \\
0.0012\end{array}\right.$} & $\left.\begin{array}{c}0.0007 \\
(2.38640-05) \\
0.9993\end{array}\right]$ \\
\hline copper & {$\left[\begin{array}{l}\text { SP500 } \\
\text { copper }\end{array}\right.$} & $\begin{array}{c}S P 500 \\
1.00\end{array}$ & $\left.\begin{array}{c}\text { copper } \\
0.14 \\
1.00\end{array}\right]$ & {$\left[\begin{array}{l}\text { SP500 } \\
\text { copper }\end{array}\right.$} & $\begin{array}{c}S P 500 \\
1.00\end{array}$ & $\left.\begin{array}{c}\text { copper } \\
0.49 \\
1.00\end{array}\right]$ & $\begin{array}{l}S P 500 \\
\text { copper }\end{array}$ & $\begin{array}{c}S P 500 \\
0.6161 \\
(1.6989 e-03)\end{array}$ & $\begin{array}{c}\text { copper } \\
0.0847 \\
(1.717770-04) \\
0.6256 \\
(1.794060-03)\end{array}$ & $\begin{array}{l}\text { SP500 } \\
\text { copper }\end{array}$ & $\begin{array}{c}S P 500 \\
0.357 \\
(2.1743 e-03) \\
\end{array}$ & $\begin{array}{c}\text { copper } \\
0.1834 \\
(2.0636-04) \\
0.3734 \\
(2.137344-03)\end{array}$ & {$\left[\begin{array}{c}0.9989 \\
(1.53340-06) \\
0.0011\end{array}\right.$} & $\left.\begin{array}{c}0.0007 \\
(2.65700-077) \\
0.9993\end{array}\right]$ \\
\hline nickel & $\mid \begin{array}{l}\text { SP500 } \\
\text { nickel }\end{array}$ & $\begin{array}{c}S P 500 \\
1.00\end{array}$ & $\left.\begin{array}{c}\text { nickel } \\
0.12 \\
1.00\end{array}\right]$ & {$\left[\begin{array}{l}\text { SP500 } \\
\text { nickel }\end{array}\right.$} & $\begin{array}{l}S P 500 \\
1.00\end{array}$ & $\left.\begin{array}{c}\text { nickel } \\
0.37 \\
1.00\end{array}\right]$ & $\begin{array}{l}\text { SP500 } \\
\text { nickel }\end{array}$ & $\begin{array}{c}S P 500 \\
0.5703 \\
(5.4426 e+00) \\
\end{array}$ & $\begin{array}{c}\text { nickel } \\
0.0675 \\
(4.231212-03) \\
0.5926 \\
(3.36949-01)\end{array}$ & $\begin{array}{l}\text { SP500 } \\
\text { nickel }\end{array}$ & $\begin{array}{c}S P 500 \\
0.4215 \\
(5.5615 e-01) \\
\end{array}$ & $\begin{array}{c}\text { nickel } \\
0.1527 \\
(1.0154+-01) \\
0.4074 \\
(5.3697 e-011)\end{array}$ & {$\left[\begin{array}{c}0.9989 \\
(3.31740-05) \\
0.0011\end{array}\right.$} & $\left.\begin{array}{c}0.0007 \\
(3.9848 e-077) \\
0.9993\end{array}\right]$ \\
\hline lead & $\begin{array}{c}\text { SP500 } \\
\text { lead }\end{array}$ & $\begin{array}{c}S P 500 \\
1.00\end{array}$ & $\left.\begin{array}{l}\text { lead } \\
0.11 \\
1.00\end{array}\right]$ & $\begin{array}{l}\text { SP500 } \\
\text { lead }\end{array}$ & $\begin{array}{c}S P 500 \\
1.00\end{array}$ & $\left.\begin{array}{c}\text { lead } \\
0.44 \\
1.00\end{array}\right]$ & $\begin{array}{c}\text { SP500 } \\
\text { lead }\end{array}$ & $\begin{array}{c}S P 500 \\
0.6444 \\
(1.3189 e-03)\end{array}$ & $\begin{array}{c}l e a d \\
0.0681 \\
(3.72120-04) \\
0.6518 \\
(2.2661 e-03)\end{array}$ & $\begin{array}{l}S P 500 \\
\text { lead }\end{array}$ & $\begin{array}{c}S P 500 \\
0.3474 \\
(2.5956 e-03) \\
\end{array}$ & $\begin{array}{c}\text { lead } \\
0.1515 \\
(3.45990-04) \\
0.3481 \\
(2.55666-03)\end{array}$ & {$\left[\begin{array}{c}0.9988 \\
(5.9617 e-06) \\
0.0012\end{array}\right.$} & $\left.\begin{array}{c}0.0006 \\
(2.7898 e-07) \\
0.9994\end{array}\right]$ \\
\hline $\operatorname{tin}$ & {$\left[\begin{array}{c}S P 500 \\
\operatorname{tin}\end{array}\right.$} & $\begin{array}{c}S P 500 \\
1.00\end{array}$ & $\left.\begin{array}{c}\operatorname{tin} \\
0.09 \\
1.00\end{array}\right]$ & {$\left[\begin{array}{c}S P 500 \\
\text { tin }\end{array}\right.$} & $\begin{array}{c}S P 500 \\
1.00\end{array}$ & $\left.\begin{array}{c}\text { tin } \\
0.39 \\
1.00\end{array}\right]$ & $\begin{array}{c}S P 500 \\
\operatorname{tin}\end{array}$ & $\begin{array}{c}S P 500 \\
0.5918 \\
(1.0305 e-02)\end{array}$ & 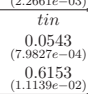 & $\begin{array}{l}S P 500 \\
\operatorname{tin}\end{array}$ & $\begin{array}{c}S P 500 \\
0.4000 \\
(2.1282 e-02) \\
\end{array}$ & $\begin{array}{c}\text { tin } \\
0.1559 \\
(4.2974 \mathrm{e}-03) \\
0.3936 \\
(1.7700 \mathrm{e}-02)\end{array}$ & {$\left[\begin{array}{c}0.9990 \\
(5.2023-06) \\
0.0010\end{array}\right.$} & $\left.\begin{array}{c}0.0007 \\
(5.172020-07) \\
0.9993\end{array}\right]$ \\
\hline zinc & $\begin{array}{c}S P 500 \\
\text { zinc }\end{array}$ & $\begin{array}{c}S P 500 \\
1.00\end{array}$ & $\left.\begin{array}{c}z i n c \\
0.10 \\
1.00\end{array}\right]$ & {$\left[\begin{array}{l}S P 500 \\
\text { zinc }\end{array}\right.$} & $\begin{array}{c}S P 500 \\
1.00\end{array}$ & $\left.\begin{array}{c}z i n c \\
0.40 \\
1.00\end{array}\right]$ & $\begin{array}{l}\text { SP500 } \\
\text { zinc }\end{array}$ & $\begin{array}{c}S P 500 \\
0.60030 \\
(2.8418 e-01)\end{array}$ & $\begin{array}{c}z i n c \\
0.0610 \\
(6.93060-05) \\
0.6194 \\
(3.12722 e-01) \\
\end{array}$ & $\begin{array}{l}S P 500 \\
z i n c\end{array}$ & $\begin{array}{c}S P 500 \\
0.3889 \\
(2.3655 e-03)\end{array}$ & $\begin{array}{c}z i n c \\
0.1519 \\
(2.1684 e-03) \\
0.3792 \\
(3.3393 e-03)\end{array}$ & {$\left[\begin{array}{c}0.9983 \\
(1.4361 e-04) \\
0.0017\end{array}\right.$} & $\left.\begin{array}{c}0.0012 \\
(1.78912-055) \\
0.9988\end{array}\right]$ \\
\hline corn & $\begin{array}{c}S P 500 \\
\text { corn }\end{array}$ & $\begin{array}{c}S P 500 \\
1.00\end{array}$ & $\left.\begin{array}{c}\text { corn } \\
0.04 \\
1.00\end{array}\right]$ & $\begin{array}{l}\text { SP500 } \\
\text { corn }\end{array}$ & $\begin{array}{c}S P 500 \\
1.00\end{array}$ & $\left.\begin{array}{l}\text { corn } \\
0.31 \\
1.00\end{array}\right]$ & $\begin{array}{c}\text { SP500 } \\
\text { corn }\end{array}$ & $\begin{array}{c}S P 500 \\
0.6961 \\
(9.2982 e-02) \\
\end{array}$ & $\begin{array}{c}\text { corn } \\
0.0261 \\
(7.09996-04) \\
0.6872 \\
(1.61272-01)\end{array}$ & $\begin{array}{l}\text { SP500 } \\
\text { corn }\end{array}$ & $\begin{array}{c}S P 500 \\
0.2957 \\
(4.5279 e-02) \\
\end{array}$ & $\begin{array}{c}\text { corn } \\
0.0970 \\
(3.3222-03) \\
0.3414 \\
(6.2690 e-02)\end{array}$ & {$\left[\begin{array}{c}0.9981 \\
(2.0201 e-04) \\
0.0019\end{array}\right.$} & $\left.\begin{array}{c}0.0008 \\
(3.7586 e-06) \\
0.9992\end{array}\right]$ \\
\hline soybeans & $\begin{array}{l}S P 500 \\
\text { soyb. }\end{array}$ & $\begin{array}{l}S P 500 \\
1.00\end{array}$ & $\left.\begin{array}{c}\text { soyb. } \\
0.05 \\
1.00\end{array}\right]$ & {$\left[\begin{array}{c}S P 500 \\
\text { soyb. }\end{array}\right.$} & $\begin{array}{c}S P 500 \\
1.00\end{array}$ & $\left.\begin{array}{c}\text { soyb. } \\
0.33 \\
1.00\end{array}\right]$ & $\begin{array}{l}S P 500 \\
\text { soyb. }\end{array}$ & $\begin{array}{c}S P 500 \\
0.6380 \\
(2.8043 e+00)\end{array}$ & $\begin{array}{c}(1.012720 .01) \\
\text { soyb } \\
0.0312 \\
(4.631818-03) \\
0.6573 \\
(1.87555 e+00)\end{array}$ & $\begin{array}{l}\text { SP500 } \\
\text { soyb. }\end{array}$ & $\begin{array}{c}S P 500 \\
0.3538 \\
(4.5083 e-01) \\
\end{array}$ & $\begin{array}{c}(\text { b.2690e-02) } \\
\text { soyb. } \\
0.1174 \\
(5.1427 e-02) \\
0.3492 \\
(4.6022 e-01)\end{array}$ & {$\left[\begin{array}{c}0.9989 \\
(9.54120-06) \\
0.0011\end{array}\right.$} & $\left.\begin{array}{c}0.0007 \\
(1.0393 e-07) \\
0.9993\end{array}\right]$ \\
\hline soybean oil & $\begin{array}{l}\text { SP500 } \\
\text { soyb. }\end{array}$ & $\begin{array}{l}S P 500 \\
1.00\end{array}$ & $\left.\begin{array}{c}\text { soyb. } \\
0.03 \\
1.00\end{array}\right]$ & {$\left[\begin{array}{l}S P 500 \\
\text { soyb. }\end{array}\right.$} & $\begin{array}{c}S P 500 \\
1.00\end{array}$ & $\left.\begin{array}{c}\text { soyb. } \\
0.37 \\
1.00\end{array}\right]$ & $\begin{array}{l}S P 500 \\
\text { soyb. }\end{array}$ & $\begin{array}{c}S P 500 \\
0.6181 \\
(1.6110 e-01) \\
\end{array}$ & $\begin{array}{c}1.0750 y b \\
\text { soyb } \\
0.0195 \\
(1.376-603) \\
0.6311 \\
(9.3492 e-02) \\
\end{array}$ & $\begin{array}{l}\text { SP500 } \\
\text { soyb. }\end{array}$ & $\begin{array}{c}S P 500 \\
0.3738 \\
(7.9579 e-02) \\
\end{array}$ & $\begin{array}{c}(4.6022 e-01) \\
\text { soyb. } \\
0.1404 \\
(4.7772 e-03) \\
0.3759 \\
(8.1442 e-02)\end{array}$ & 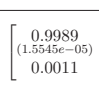 & $\left.\begin{array}{c}0.0007 \\
(5.64212-077) \\
0.9993\end{array}\right]$ \\
\hline wheat & {$\left[\begin{array}{l}\text { SP500 } \\
\text { wheat }\end{array}\right.$} & $\begin{array}{c}S P 500 \\
1.00\end{array}$ & $\left.\begin{array}{c}\text { wheat } \\
-0.01 \\
1.00\end{array}\right]$ & {$\left[\begin{array}{l}\text { SP500 } \\
\text { wheat }\end{array}\right.$} & $\begin{array}{l}S P 500 \\
1.00\end{array}$ & $\left.\begin{array}{c}\text { wheat } \\
0.34 \\
1.00\end{array}\right]$ & $\begin{array}{l}\text { SP500 } \\
\text { wheat }\end{array}$ & $\begin{array}{c}S P 500 \\
0.6891 \\
(3.0126 e+01)\end{array}$ & $\begin{array}{c}\text { wheat } \\
-0.0097 \\
(2.3915-0.02) \\
0.6973 \\
(1.7218 e+01)\end{array}$ & $\begin{array}{l}\text { SP500 } \\
\text { wheat }\end{array}$ & $\begin{array}{c}S P 500 \\
0.3028 \\
(5.7432 e-02)\end{array}$ & $\begin{array}{c}\text { wheat } \\
0.1055 \\
(1.3350 e-02) \\
0.3123 \\
(6.6470 e-02)\end{array}$ & {$\left[\begin{array}{c}0.9951 \\
(1.10155-04) \\
0.0049\end{array}\right.$} & $\left.\begin{array}{c}0.0022 \\
(6.86744-06) \\
0.9978\end{array}\right]$ \\
\hline coffe & $\begin{array}{l}\text { SP500 } \\
\text { coffe }\end{array}$ & $\begin{array}{c}S P 500 \\
1.00\end{array}$ & $\left.\begin{array}{c}\operatorname{coffe} \\
0.02 \\
1.00\end{array}\right]$ & {$\left[\begin{array}{l}\text { SP500 } \\
\text { coffe }\end{array}\right.$} & $\begin{array}{l}S P 500 \\
1.00\end{array}$ & $\left.\begin{array}{c}\text { coffe } \\
0.31 \\
1.00\end{array}\right]$ & $\begin{array}{l}S P 500 \\
\text { coffe }\end{array}$ & $\begin{array}{c}S P 500 \\
0.5463 \\
(3.0938 e-01) \\
\end{array}$ & $\begin{array}{c}c \text { cof fee } \\
0.0113 \\
(1.41313-05) \\
0.5722 \\
(3.4478 \varepsilon+00)\end{array}$ & $\begin{array}{l}\text { SP500 } \\
\text { coffe }\end{array}$ & $\begin{array}{c}S P 500 \\
0.4456 \\
(1.1492 e+00)\end{array}$ & $\begin{array}{c}c o f f e \\
0.1342 \\
(1.0917 e-01) \\
0.4278 \\
(1.2339 e+00)\end{array}$ & {$\left[\begin{array}{c}0.9965 \\
(2.08994-05) \\
0.0035\end{array}\right.$} & $\left.\begin{array}{c}0.0024 \\
(3.7688 e-06) \\
0.9976\end{array}\right]$ \\
\hline cotton & $\begin{array}{l}\text { SP500 } \\
\text { cotton }\end{array}$ & $\begin{array}{c}S P 500 \\
1.00\end{array}$ & $\left.\begin{array}{c}\text { cotton } \\
0.03 \\
1.00\end{array}\right]$ & {$\left[\begin{array}{l}S P 500 \\
\text { cotton }\end{array}\right.$} & $\begin{array}{l}S P 500 \\
1.00\end{array}$ & $\left.\begin{array}{c}\text { cotton } \\
0.27 \\
1.00\end{array}\right]$ & $\begin{array}{l}S P 500 \\
\text { cotton }\end{array}$ & $\begin{array}{c}S P 500 \\
0.4644 \\
(4.4032 e-02) \\
\end{array}$ & $\begin{array}{c}\text { cotton } \\
0.0131 \\
(1.65522-04) \\
0.4875 \\
(4.95572-02)\end{array}$ & $\begin{array}{l}\text { SP500 } \\
\text { cotton }\end{array}$ & $\begin{array}{c}\text { SP500 } \\
0.5275 \\
(6.6034 e-03) \\
\end{array}$ & $\begin{array}{c}\text { cotton } \\
0.1411 \\
(2.2068<-04) \\
0.5273 \\
(6.5990 e-03)\end{array}$ & {$\left[\begin{array}{c}1.0000 \\
(5.2246 e-12) \\
0.0000\end{array}\right.$} & $\left.\begin{array}{c}0.0007 \\
(1.0229 e-05) \\
0.9993\end{array}\right]$ \\
\hline orange juice & $\begin{array}{l}\text { SP500 } \\
\text { oran. }\end{array}$ & $\begin{array}{l}S P 500 \\
1.00\end{array}$ & $\left.\begin{array}{c}\text { oran. } \\
0.01 \\
1.00\end{array}\right]$ & {$\left[\begin{array}{l}\text { SP500 } \\
\text { oran. }\end{array}\right.$} & $\begin{array}{c}S P 500 \\
1.00\end{array}$ & $\left.\begin{array}{c}\text { oran. } \\
0.19 \\
1.00\end{array}\right]$ & $\begin{array}{l}\text { SP500 } \\
\text { oran. }\end{array}$ & $\begin{array}{c}S P 500 \\
0.5286 \\
(8.1483 e+03)\end{array}$ & $\begin{array}{c}\text { oran. } \\
0.0037 \\
(6.901010-04) \\
0.5354 \\
(8.5470 e+03)\end{array}$ & $\begin{array}{l}\text { SP500 } \\
\text { oran. }\end{array}$ & $\begin{array}{c}S P 500 \\
0.4632 \\
(5.1971 e-02)\end{array}$ & $\begin{array}{c}\text { oran. } \\
0.0864 \\
(4.2020-03) \\
0.4673 \\
(1.0121 e-01)\end{array}$ & {$\left[\begin{array}{c}0.9973 \\
(8.521210-06) \\
0.0027\end{array}\right.$} & $\left.\begin{array}{c}0.0030 \\
(4.101110-066) \\
0.9970\end{array}\right]$ \\
\hline barely & {$\left[\begin{array}{l}\text { SP500 } \\
\text { barely }\end{array}\right.$} & $\begin{array}{c}S P 500 \\
1.00\end{array}$ & $\left.\begin{array}{c}\text { barely } \\
-0.01 \\
1.00\end{array}\right]$ & {$\left[\begin{array}{l}\text { SP500 } \\
\text { barely }\end{array}\right.$} & $\begin{array}{l}S P 500 \\
1.00\end{array}$ & $\left.\begin{array}{c}\text { barely } \\
-0.01 \\
1.00\end{array}\right]$ & $\begin{array}{l}\text { SP500 } \\
\text { barely }\end{array}$ & $\begin{array}{c}S P 500 \\
0.4968 \\
(2.3269 e-01)\end{array}$ & 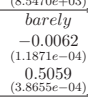 & $\begin{array}{l}\text { SP500 } \\
\text { barely }\end{array}$ & $\begin{array}{c}S P 500 \\
0.4950 \\
(5.3960 e-01)\end{array}$ & $\begin{array}{c}\text { barely } \\
-0.0062 \\
(6.5441 e-04) \\
0.5041 \\
(5.9019 e-01)\end{array}$ & {$\left[\begin{array}{c}0.9932 \\
(3.6725 e-01) \\
0.0068\end{array}\right.$} & $\left.\begin{array}{c}0.0066 \\
(5.62906-06) \\
0.9932\end{array}\right]$ \\
\hline oat & {$\left[\begin{array}{c}S P 500 \\
\text { oat }\end{array}\right.$} & $\begin{array}{c}S P 500 \\
1.00\end{array}$ & $\left.\begin{array}{c}\text { oat } \\
-0.06 \\
1.00\end{array}\right]$ & {$\left[\begin{array}{c}S P 500 \\
\text { oat }\end{array}\right.$} & $\begin{array}{c}S P 500 \\
1.00\end{array}$ & $\left.\begin{array}{c}\text { oat } \\
0.27 \\
1.00\end{array}\right]$ & $\begin{array}{c}\text { SP500 } \\
\text { oat }\end{array}$ & $\begin{array}{c}S P 500 \\
0.5425 \\
(1.3874 e-01)\end{array}$ & 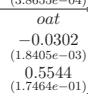 & $\begin{array}{c}\text { SP } 500 \\
\text { oat }\end{array}$ & $\begin{array}{c}S P 500 \\
0.4494 \\
(7.1162 e-02)\end{array}$ & $\begin{array}{c}\text { oat } \\
0.1222 \\
(4.6095 e-03) \\
0.4522 \\
(7.3456 e-02)\end{array}$ & {$\left[\begin{array}{c}0.9888 \\
(1.46969-04) \\
0.0112\end{array}\right.$} & $\left.\begin{array}{c}0.0099 \\
(5.81919-05) \\
0.9901\end{array}\right]$ \\
\hline rice & {$\left[\begin{array}{c}\text { SP500 } \\
\text { rice }\end{array}\right.$} & $\begin{array}{c}S P 500 \\
1.00\end{array}$ & $\left.\begin{array}{c}\text { rice } \\
-0.00 \\
1.00\end{array}\right]$ & $\begin{array}{c}\text { SP500 } \\
\text { rice }\end{array}$ & $\begin{array}{c}S P 500 \\
1.00\end{array}$ & $\left.\begin{array}{l}\text { rice } \\
0.22 \\
1.00\end{array}\right]$ & $\begin{array}{c}\text { SP500 } \\
\text { rice }\end{array}$ & $\begin{array}{c}S P 500 \\
0.6104 \\
(3.9854 e+02)\end{array}$ & $\begin{array}{c}\text { rice } \\
-0.0015 \\
(3.20633-06) \\
0.6223 \\
(4.1566 e+02)\end{array}$ & $\begin{array}{l}S P 500 \\
\text { rice }\end{array}$ & $\begin{array}{c}\text { SP500 } \\
0.3815 \\
(5.2947 e-03)\end{array}$ & $\begin{array}{c}\text { rice } \\
0.0868 \\
(4.40033-05) \\
0.4037 \\
(2.6815 e-03)\end{array}$ & {$\left[\begin{array}{c}0.9988 \\
(2.46520-06) \\
0.0012\end{array}\right.$} & $\left.\begin{array}{c}0.0007 \\
(1.3989 e-07) \\
0.9993\end{array}\right]$ \\
\hline palm oil & {$\left[\begin{array}{l}\text { SP500 } \\
\text { palm. }\end{array}\right.$} & $\begin{array}{c}S P 500 \\
1.00\end{array}$ & $\left.\begin{array}{c}\text { palm. } \\
-0.03 \\
1.00\end{array}\right]$ & {$\left[\begin{array}{l}\text { SP500 } \\
\text { palm. }\end{array}\right.$} & $\begin{array}{l}S P 500 \\
1.00\end{array}$ & $\left.\begin{array}{c}\text { palm. } \\
0.16 \\
1.00\end{array}\right]$ & $\begin{array}{l}\text { SP500 } \\
\text { palm. }\end{array}$ & $\begin{array}{c}S P 500 \\
0.5651 \\
(3.3941 e-01)\end{array}$ & $\begin{array}{c}\text { palm. } \\
-0.0181 \\
(1.2978-04) \\
0.5727 \\
(3.26722-01) \\
\end{array}$ & $\begin{array}{l}\text { SP500 } \\
\text { palm. }\end{array}$ & $\begin{array}{c}S P 500 \\
0.4267 \\
(7.0878 e-02)\end{array}$ & $\begin{array}{c}\text { palm. } \\
0.0661 \\
(1.4891 e-03) \\
0.4240 \\
(6.8109 e-02)\end{array}$ & {$\left[\begin{array}{c}0.9985 \\
(9.2416 e-06) \\
0.0015\end{array}\right.$} & {$\left[\begin{array}{c}0.0011 \\
(1.4342 e-06) \\
0.9989\end{array}\right]$} \\
\hline cocao & $\begin{array}{l}S P 500 \\
\text { cocao }\end{array}$ & $\begin{array}{l}S P 500 \\
1.00\end{array}$ & $\left.\begin{array}{c}\text { cocao } \\
0.06 \\
1.00\end{array}\right]$ & {$\left[\begin{array}{l}S P 500 \\
\text { cocao }\end{array}\right.$} & $\begin{array}{c}S P 500 \\
1.00\end{array}$ & $\left.\begin{array}{c}\text { cocao } \\
0.27 \\
1.00\end{array}\right]$ & $\begin{array}{l}\text { SP500 } \\
\text { cocao }\end{array}$ & $\begin{array}{c}S P 500 \\
0.5738 \\
(1.4777 e-03)\end{array}$ & $\begin{array}{c}c \text { cocao } \\
0.0330 \\
(1.8500-04) \\
0.5889 \\
(9.62980-04)\end{array}$ & $\begin{array}{l}\text { SP500 } \\
\text { cocao }\end{array}$ & $\begin{array}{c}S P 500 \\
0.4180 \\
(1.0153 e-03)\end{array}$ & $\begin{array}{c}c o c a 0 \\
0.1099 \\
(1.3199-04) \\
0.4109 \\
(7.67199-04)\end{array}$ & {$\left[\begin{array}{c}0.9990 \\
(3.3818-06) \\
0.0010\end{array}\right.$} & $\left.\begin{array}{c}0.0008 \\
(5.3457 e-07) \\
0.9992\end{array}\right]$ \\
\hline sugar & $\begin{array}{l}\text { SP500 } \\
\text { sugar }\end{array}$ & $\begin{array}{c}S P 500 \\
1.00\end{array}$ & $\left.\begin{array}{c}\text { sugar } \\
-0.02 \\
1.00\end{array}\right]$ & {$\left[\begin{array}{l}\text { SP500 } \\
\text { sugar }\end{array}\right.$} & $\begin{array}{c}S P 500 \\
1.00\end{array}$ & $\left.\begin{array}{c}\text { sugar } \\
0.25 \\
1.00\end{array}\right]$ & $\begin{array}{l}S P 500 \\
\text { sugar }\end{array}$ & $\begin{array}{c}S P 500 \\
0.5215 \\
(5.1037 e-03) \\
\end{array}$ & $\begin{array}{c}\text { sugar } \\
-0.0122 \\
(1.48412-04) \\
0.5193 \\
(1.7366 e-03)\end{array}$ & $\begin{array}{l}\text { SP500 } \\
\text { sugar }\end{array}$ & $\begin{array}{c}\text { SP500 } \\
0.4703 \\
(2.6608 e-03) \\
\end{array}$ & $\begin{array}{c}\text { sugar } \\
0.1206 \\
(1.207230-04) \\
0.4959 \\
(2.7099 e-03)\end{array}$ & {$\left[\begin{array}{c}0.9991 \\
(6.64411-07) \\
0.0009\end{array}\right.$} & $\left.\begin{array}{c}0.0008 \\
(3.0887 e-07) \\
0.9992\end{array}\right]$ \\
\hline lumber & {$\left[\begin{array}{l}\text { SP500 } \\
\text { lumber }\end{array}\right.$} & $\begin{array}{c}S P 500 \\
1.00\end{array}$ & $\left.\begin{array}{c}\text { lumber } \\
0.13 \\
1.00\end{array}\right]$ & $\begin{array}{l}\text { SP500 } \\
\text { lumber }\end{array}$ & $\begin{array}{l}S P 500 \\
1.00\end{array}$ & $\left.\begin{array}{c}\text { lumber } \\
0.13 \\
1.00\end{array}\right]$ & $\begin{array}{l}\text { SP500 } \\
\text { lumber }\end{array}$ & $\begin{array}{c}\text { SP500 } \\
0.4967 \\
(2.1669 e-04) \\
\end{array}$ & $\begin{array}{c}\text { lumber } \\
0.0629 \\
(4.3958-05) \\
0.5011 \\
(2.782010-04)\end{array}$ & $\begin{array}{l}\text { SP500 } \\
\text { lumber }\end{array}$ & $\begin{array}{c}S P 500 \\
0.4952 \\
(2.1503 e-03) \\
\end{array}$ & $\begin{array}{c}\text { lumber } \\
0.0636 \\
(1.6388-05) \\
0.4996 \\
(2.2722 e-03)\end{array}$ & {$\left[\begin{array}{c}0.9932 \\
(3.99922-05) \\
0.0068\end{array}\right.$} & $\left.\begin{array}{c}0.0068 \\
(1.1753 e-077) \\
0.9932\end{array}\right]$ \\
\hline sunflower & $\begin{array}{l}\text { SP500 } \\
\text { sunf. }\end{array}$ & $\begin{array}{c}S P 500 \\
1.00\end{array}$ & $\left.\begin{array}{c}\text { sunf. } \\
-0.09 \\
1.00\end{array}\right]$ & {$\left[\begin{array}{l}\text { SP500 } \\
\text { sunf. }\end{array}\right.$} & $\begin{array}{l}S P 500 \\
1.00\end{array}$ & $\left.\begin{array}{c}\operatorname{sunf} . \\
0.06 \\
1.00\end{array}\right]$ & $\begin{array}{l}\text { SP500 } \\
\text { sunf. }\end{array}$ & $\begin{array}{c}S P 500 \\
0.4835 \\
(1.9411 e-01) \\
\end{array}$ & 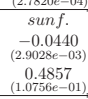 & $\begin{array}{l}\text { SP500 } \\
\text { sunf. }\end{array}$ & $\begin{array}{c}S P 500 \\
0.5083 \\
(1.4238 e-02) \\
\end{array}$ & $\begin{array}{c}\text { sunf. } \\
0.0304 \\
(2.9859 e-04) \\
0.5218 \\
(2.8744 e-02) \\
\end{array}$ & {$\left[\begin{array}{c}0.9906 \\
(1.4004 e-05) \\
0.0094\end{array}\right.$} & $\left.\begin{array}{c}0.0101 \\
(1.6983 e-05) \\
0.9899\end{array}\right]$ \\
\hline lean hogs & {$\left[\begin{array}{l}\text { SP500 } \\
\text { lean. }\end{array}\right.$} & $\begin{array}{c}S P 500 \\
1.00\end{array}$ & $\left.\begin{array}{c}\text { lean. } \\
-0.04 \\
1.00\end{array}\right]$ & {$\left[\begin{array}{l}\text { SP500 } \\
\text { lean. }\end{array}\right.$} & $\begin{array}{c}S P 500 \\
1.00\end{array}$ & $\left.\begin{array}{r}\text { lean. } \\
0.15 \\
1.00\end{array}\right]$ & $\begin{array}{l}\text { SP500 } \\
\text { lean. }\end{array}$ & $\begin{array}{c}S P 500 \\
0.5205 \\
(1.0452 e+02) \\
\end{array}$ & $\begin{array}{c}(1.0750 e-01) \\
\text { lean. } \\
-0.0213 \\
(8.118210-01) \\
0.5299 \\
(6.3541 e+00) \\
\end{array}$ & $\begin{array}{l}\text { SP500 } \\
\text { lean. }\end{array}$ & $\begin{array}{c}S P 500 \\
0.4713 \\
(8.5893 e+01)\end{array}$ & $\begin{array}{c}\text { lean. } \\
0.0690 \\
(1.5878 e+00) \\
0.4740 \\
(1.1786 e+02) \\
\end{array}$ & {$\left[\begin{array}{c}0.9984 \\
(1.12300-03) \\
0.0016\end{array}\right.$} & $\left.\begin{array}{c}0.0019 \\
(1.4966-05) \\
0.9981\end{array}\right]$ \\
\hline live cattle & {$\left[\begin{array}{l}\text { SP500 } \\
\text { live. }\end{array}\right.$} & $\begin{array}{l}S P 500 \\
1.00\end{array}$ & $\left.\begin{array}{c}\text { live. } \\
-0.05 \\
1.00\end{array}\right]$ & $\begin{array}{l}\text { SP500 } \\
\text { live. }\end{array}$ & $\begin{array}{c}S P 500 \\
1.00\end{array}$ & $\left.\begin{array}{l}\text { live. } \\
0.32 \\
1.00\end{array}\right]$ & $\begin{array}{l}\text { SP500 } \\
\text { live. }\end{array}$ & $\begin{array}{c}S P 500 \\
0.5602 \\
(1.3011 e-01) \\
\end{array}$ & $\begin{array}{c}\text { live. } \\
-0.0261 \\
(2.19912-0.04) \\
0.5598 \\
(1.23616-01)\end{array}$ & $\begin{array}{l}\text { SP500 } \\
\text { live. }\end{array}$ & $\begin{array}{c}S P 500 \\
0.4316 \\
(4.2484 e-02) \\
\end{array}$ & $\begin{array}{c}\text { live. } \\
0.1385 \\
(9.43280-03) \\
0.4347 \\
(4.59110-02)\end{array}$ & {$\left[\begin{array}{c}0.9942 \\
(4.1092 e-04) \\
0.0058\end{array}\right.$} & $\left.\begin{array}{c}0.0047 \\
(1.7089 e-04) \\
0.9953\end{array}\right]$ \\
\hline feeder cattle & {$\left[\begin{array}{l}\text { SP500 } \\
\text { feed. }\end{array}\right.$} & $\begin{array}{l}S P 500 \\
1.00\end{array}$ & $\left.\begin{array}{c}\text { feed. } \\
-0.05 \\
1.00\end{array}\right]$ & {$\left[\begin{array}{l}\text { SP500 } \\
\text { feed. }\end{array}\right.$} & $\begin{array}{c}S P 500 \\
1.00\end{array}$ & $\left.\begin{array}{c}\text { feed. } \\
0.30 \\
1.00\end{array}\right]$ & $\begin{array}{l}\text { SP500 } \\
\text { feed. }\end{array}$ & $\begin{array}{c}S P 500 \\
0.6308 \\
(2.7738 e-01)\end{array}$ & $\begin{array}{c}\text { feed. } \\
-0.0354 \\
(1.7414-04) \\
0.6710 \\
(3.3240 e-01) \\
\end{array}$ & $\begin{array}{l}S P 500 \\
\text { feed. }\end{array}$ & $\begin{array}{c}S P 500 \\
0.3610 \\
(6.7919 e-02) \\
\end{array}$ & $\begin{array}{c}f e e d . \\
0.1052 \\
(4.2680 e-03) \\
0.3402 \\
(6.0727 e-02)\end{array}$ & {$\left[\begin{array}{c}0.9886 \\
(1.1 .1366-04) \\
0.0114\end{array}\right.$} & $\left.\begin{array}{c}0.0061 \\
(1.5713 e-05) \\
0.9939\end{array}\right]$ \\
\hline
\end{tabular}


Table 10: Co-movements between commodities and US Bonds.

\begin{tabular}{|c|c|c|c|c|c|c|c|c|c|c|c|c|c|c|}
\hline & \multicolumn{3}{|c|}{$\dot{R}_{1}$} & \multicolumn{3}{|c|}{$\hat{R}_{2}$} & \multicolumn{3}{|c|}{$\bar{C}_{1}$} & \multicolumn{3}{|c|}{$\hat{C}_{2}$} & \multicolumn{2}{|c|}{$\hat{P}$} \\
\hline DJUBS & $\begin{array}{c}D J U B S \\
\text { JPMUSU }\end{array}$ & $\begin{array}{c}D J U B S \\
1.00\end{array}$ & $\left.\begin{array}{c}J P M U S U \\
0.05 \\
1.00\end{array}\right]$ & $\begin{array}{c}D J U B S \\
\text { JPMUSU }\end{array}$ & $\begin{array}{c}D J U B S \\
1.00\end{array}$ & $\left.\begin{array}{c}J P M U S U \\
-0.34 \\
1.00\end{array}\right]$ & \begin{tabular}{|c|} 
DJUBS \\
JPMUSU
\end{tabular} & $\begin{array}{c}D J U B S \\
0.5361 \\
(5.2714 e-02)\end{array}$ & $\begin{array}{c}J P M U S U \\
0.0284 \\
(5.20866-04) \\
0.5247 \\
(6.97888-02)\end{array}$ & $\begin{array}{c}\text { DJUBS } \\
\text { JPMUSU }\end{array}$ & $\begin{array}{c}D J U B S \\
0.4739 \\
(1.1562 e-01)\end{array}$ & $\begin{array}{c}J P M U S U \\
-0.1592 \\
(1.1881 e-02) \\
0.4743 \\
(1.685 e-01\end{array}$ & {$\left[\begin{array}{c}0.9969 \\
(4.8315 e-06) \\
0.0031\end{array}\right.$} & $\left.\begin{array}{c}0.0027 \\
(5.3589 e-06) \\
0.9973\end{array}\right]$ \\
\hline GSCI & $\begin{array}{c}G S C I \\
J P M U S U\end{array}$ & $\begin{array}{c}G S C I \\
1.00\end{array}$ & $\left.\begin{array}{c}J P M U S U \\
0.02 \\
1.00\end{array}\right]$ & $\begin{array}{c}\text { GSCI } \\
\text { JPMUSU }\end{array}$ & $\begin{array}{l}\text { GSCI } \\
1.00\end{array}$ & $\left.\begin{array}{c}J P M U S U \\
-0.42 \\
1.00\end{array}\right]$ & $\begin{array}{c}G S C I \\
\text { JPMUSU }\end{array}$ & $\begin{array}{c}G S C I \\
0.5995 \\
(1.5158 e+00)\end{array}$ & $\begin{array}{c}J P M U S U \\
0.0148 \\
(4.31909-04) \\
0.5955) \\
(2.66900000)\end{array}$ & $\begin{array}{c}G S C I \\
J P M U S U\end{array}$ & $\begin{array}{c}G S C I \\
0.3960 \\
(2.5093 e+00)\end{array}$ & $\begin{array}{c}J P M U S U \\
-0.1668 \\
(6.5271 e-02) \\
0.4036 \\
(8.0475 e+00)\end{array}$ & {$\left[\begin{array}{c}0.9975 \\
(1.143530-05) \\
0.0025\end{array}\right.$} & {$\left[\begin{array}{c}0.0017 \\
(8.2817 e-07) \\
0.9983\end{array}\right]$} \\
\hline RICI & $\begin{array}{c}R I C I \\
J P M U S U\end{array}$ & $\begin{array}{c}R I C I \\
1.00\end{array}$ & $\left.\begin{array}{c}J P M U S U \\
0.05 \\
1.00\end{array}\right]$ & $\begin{array}{c}\text { RICI } \\
\text { JPMUSU }\end{array}$ & $\begin{array}{l}R I C I \\
1.00\end{array}$ & $\left.\begin{array}{c}J P M U S U \\
-0.40 \\
1.00\end{array}\right]$ & $\begin{array}{c}\text { RICI } \\
\text { JPMUSU }\end{array}$ & $\begin{array}{c}R I C I \\
0.5424 \\
(9.6937 e-02)\end{array}$ & $\begin{array}{c}J P M U S U \\
0.0266 \\
(3.23006-04) \\
0.559 \\
(1.18363 e-01)\end{array}$ & $\begin{array}{c}\text { RICI } \\
\text { JPMUSU }\end{array}$ & $\begin{array}{c}R I C I \\
0.4489 \\
(2.2409 e-02)\end{array}$ & $\left.\begin{array}{c}J P M U S U \\
-0.1775 \\
(3.2686 e-03) \\
0.442) \\
(2.08886 e-02)\end{array}\right]$ & {$\left[\begin{array}{c}0.9961 \\
(4.0 .1856-05) \\
0.0039\end{array}\right.$} & {$\left[\begin{array}{c}0.0030 \\
(6.4312 e-06) \\
0.9970\end{array}\right]$} \\
\hline CRB & $\begin{array}{c}C R B \\
\text { JPMUSU }\end{array}$ & $\begin{array}{c}C R B \\
1.00\end{array}$ & $\left.\begin{array}{c}J P M U S U \\
0.06 \\
1.00\end{array}\right]$ & $\begin{array}{c}C R B \\
J P M U S U\end{array}$ & $\begin{array}{c}C R B \\
1.00\end{array}$ & $\left.\begin{array}{c}J P M U S U \\
-0.40 \\
1.00\end{array}\right]$ & $\begin{array}{c}C R B \\
\text { JPMUSU }\end{array}$ & $\begin{array}{c}C R B \\
0.5347 \\
(1.0627 e-02)\end{array}$ & $\begin{array}{c}J P M U S U \\
0.0309 \\
(1.6259 e-04) \\
0.5453 \\
(1.2139 e-02)\end{array}$ & $\begin{array}{c}C R B \\
J P M U S U\end{array}$ & $\begin{array}{c}C R B \\
0.4574 \\
(3.9283 e-03)\end{array}$ & $\left.\begin{array}{c}J P M U S U \\
-0.1812 \\
(1.5823 e-04) \\
(4.4538) \\
(4.1801 e-03)\end{array}\right]$ & {$\left[\begin{array}{c}0.9958 \\
(1.46040-05) \\
0.0042\end{array}\right.$} & $\left.\begin{array}{c}0.0033 \\
(3.01515 e-06) \\
0.9967\end{array}\right]$ \\
\hline
\end{tabular}

(a) Commodity indices with US Bonds.

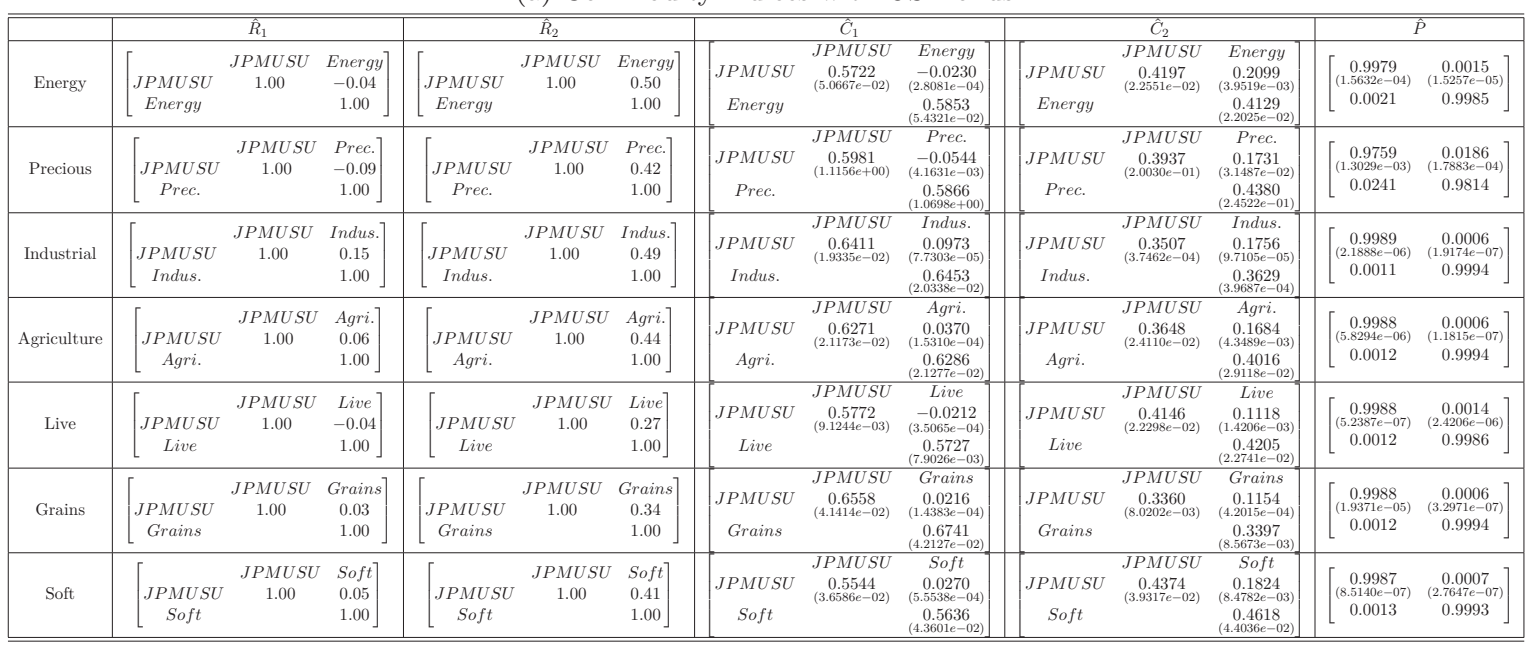

(b) Equally-weighted constructed commodity indices wih US Bonds.

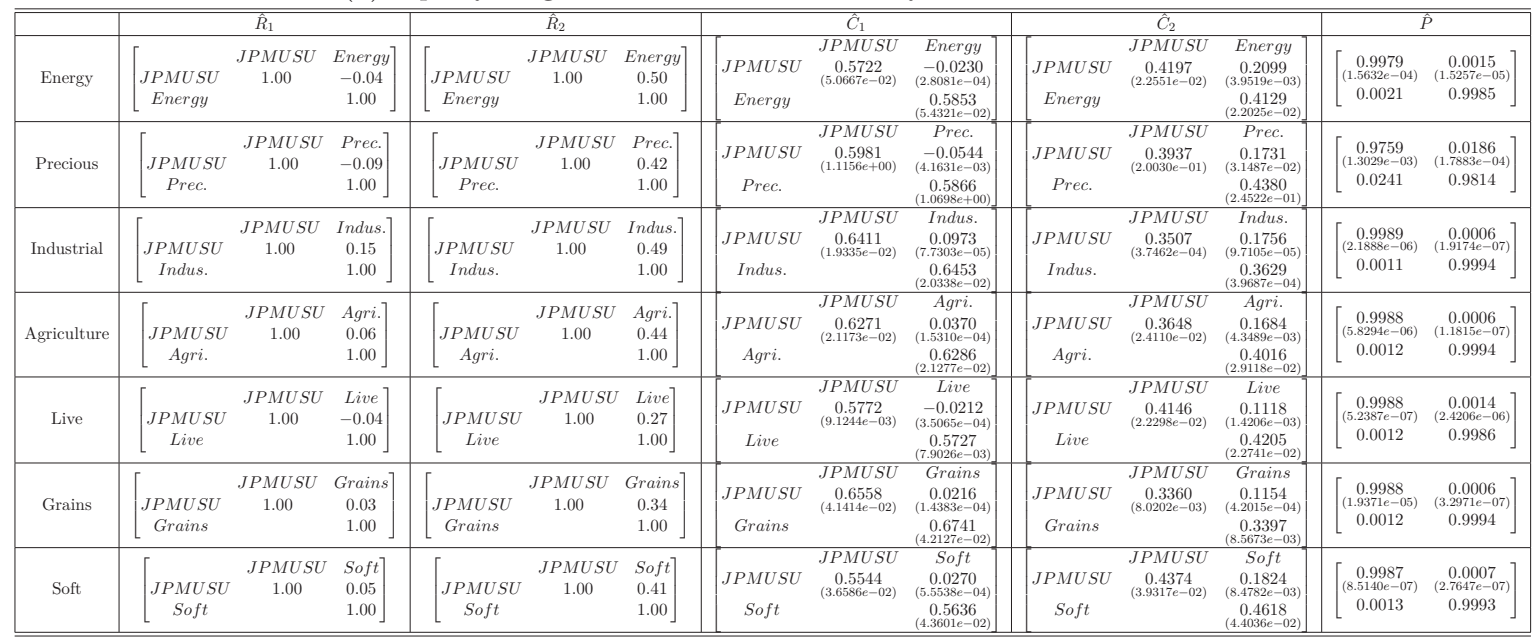

(c) Constructed commodity indices, using GSCI weights, with US Bonds. 
Table 11: Bivariate commodity-bond estimations.

\begin{tabular}{|c|c|c|c|c|c|c|c|c|c|c|c|c|c|c|}
\hline & \multicolumn{3}{|c|}{$\bar{R}_{1}$} & \multicolumn{3}{|c|}{$\bar{R}_{2}$} & \multicolumn{3}{|c|}{$\tilde{C}_{1}$} & \multicolumn{3}{|c|}{$\hat{C}_{2}$} & \multicolumn{2}{|c|}{$P$} \\
\hline wti & $\begin{array}{c}\text { jpmusu } \\
\text { wti }\end{array}$ & $\begin{array}{c}\text { jpmusu } \\
1.00\end{array}$ & $\left.\begin{array}{c}w t i \\
0.02 \\
1.00\end{array}\right]$ & {$\left[\begin{array}{c}\text { jpmusu } \\
\text { wti }\end{array}\right.$} & $\begin{array}{c}\text { jpmusu } \\
1.00\end{array}$ & $\left.\begin{array}{c}w t i \\
-0.41 \\
1.00\end{array}\right]$ & $\begin{array}{c}\text { jpmusu } \\
w t i\end{array}$ & $\begin{array}{c}\text { jpmusu } \\
0.6045 \\
(4.1961 e-01) \\
\end{array}$ & $\begin{array}{c}w t i \\
0.0129 \\
(1.72946-04) \\
0.6062 \\
(2.5758 e-01)\end{array}$ & $\begin{array}{c}\text { jpmusu } \\
w t i\end{array}$ & $\begin{array}{c}\text { jpmusu } \\
0.3946 \\
(2.2241 e-02) \\
\end{array}$ & $\begin{array}{c}w t i \\
-0.1623 \\
(3.02677-03) \\
0.3936 \\
(2.23178-02)\end{array}$ & {$\left[\begin{array}{c}0.9976 \\
(7.37666-06) \\
0.0024\end{array}\right.$} & $\left.\begin{array}{c}0.0016 \\
(7.4052 e-07) \\
0.9984\end{array}\right]$ \\
\hline heating oil & $\begin{array}{c}\text { jpmusu } \\
\text { heat. }\end{array}$ & $\begin{array}{c}j p m u s u \\
1.00\end{array}$ & $\left.\begin{array}{r}\text { heat. } \\
0.03 \\
1.00\end{array}\right]$ & $\begin{array}{c}\text { jpmusu } \\
\text { heat. }\end{array}$ & $\begin{array}{c}\text { jpmusu } \\
1.00\end{array}$ & $\left.\begin{array}{c}\text { heat. } \\
-0.38 \\
1.00\end{array}\right]$ & $\begin{array}{l}\text { jpmusu } \\
\text { heat. }\end{array}$ & $\begin{array}{c}\text { jpmusu } \\
0.5973 \\
(2.9414 e-03) \\
\end{array}$ & $\begin{array}{c}\text { heat. } \\
0.0180 \\
(1.29100-04) \\
0.6176 \\
(1.3439 e-02)\end{array}$ & $\begin{array}{c}\text { jpmusu } \\
\text { heat. }\end{array}$ & $\begin{array}{c}\text { jpmusu } \\
0.4017 \\
(3.2037 e-03) \\
\end{array}$ & $\begin{array}{c}\text { heat. } \\
-0.1494 \\
(3.4414-05) \\
0.3840 \\
(2.2831 e-03)\end{array}$ & {$\left[\begin{array}{c}0.9978 \\
(6.17850-06) \\
0.0022\end{array}\right.$} & $\left.\begin{array}{c}0.0014 \\
(7.1340 e-07) \\
0.9986\end{array}\right]$ \\
\hline natural gas & $\begin{array}{l}\text { jpmusu } \\
\text { natu. }\end{array}$ & $\begin{array}{c}\text { jpmusu } \\
1.00\end{array}$ & $\left.\begin{array}{c}\text { natu. } \\
-0.01 \\
1.00\end{array}\right]$ & {$\left[\begin{array}{c}\text { jpmusu } \\
\text { natu. }\end{array}\right.$} & $\begin{array}{c}\text { jpmusu } \\
1.00\end{array}$ & $\left.\begin{array}{c}\text { natu. } \\
-0.01 \\
1.00\end{array}\right]$ & $\begin{array}{c}\text { jpmusu } \\
\text { natu. }\end{array}$ & $\begin{array}{c}p \text { musu } \\
0.5003 \\
(2.3131 e-04) \\
\end{array}$ & $\begin{array}{c}\text { natu. } \\
-0.0035 \\
(1.0487 e-03) \\
0.5013 \\
(2.1042 e-03)\end{array}$ & $\begin{array}{c}\text { jpmusu } \\
\text { natu. }\end{array}$ & $\begin{array}{c}j p m u s u \\
0.4987 \\
(3.0122 e-01) \\
\end{array}$ & $\begin{array}{c}\text { natu. } \\
-0.0039 \\
(3.476-03) \\
0.4998 \\
(2.96020-01)\end{array}$ & {$\left[\begin{array}{c}0.9933 \\
(7.1 .16000+00) \\
0.0067\end{array}\right.$} & $\left.\begin{array}{c}0.0067 \\
(2.2112 e-04) \\
0.9933\end{array}\right]$ \\
\hline coal & {$\left[\begin{array}{c}\text { jpmusu } \\
\text { coal }\end{array}\right.$} & $\begin{array}{l}\text { jpmusu } \\
1.00\end{array}$ & $\left.\begin{array}{c}\text { coal } \\
0.12 \\
1.00\end{array}\right]$ & {$\left[\begin{array}{c}\text { jpmusu } \\
\text { coal }\end{array}\right.$} & $\begin{array}{c}\text { jpmusu } \\
1.00\end{array}$ & $\left.\begin{array}{c}c o a l \\
-0.24 \\
1.00\end{array}\right]$ & $\begin{array}{c}\text { jpmusu } \\
\text { coal }\end{array}$ & $\begin{array}{c}\text { jpmusu } \\
0.5880 \\
(1.6977 e+01) \\
\end{array}$ & $\begin{array}{c}\text { coal } \\
0.0759 \\
(5.56272-011) \\
0.6280 \\
(3.0827 e+01)\end{array}$ & $\begin{array}{c}\text { jpmusu } \\
\text { coal }\end{array}$ & $\begin{array}{c}\text { jpmusu } \\
0.4110 \\
(8.5253 c+02)\end{array}$ & $\begin{array}{c}\text { coal } \\
-0.0941 \\
(4.52899+01) \\
0.3805 \\
(7.4523 e+02)\end{array}$ & {$\left[\begin{array}{c}0.9862 \\
(2.11500-02) \\
0.0138\end{array}\right.$} & {$\left[\begin{array}{c}0.0087 \\
(3.46850-033) \\
0.9913\end{array}\right]$} \\
\hline gold & {$\left[\begin{array}{c}\text { jpmusu } \\
\text { gold }\end{array}\right.$} & $\begin{array}{c}\text { jpmusu } \\
1.00\end{array}$ & $\left.\begin{array}{c}\text { gold } \\
-0.16 \\
1.00\end{array}\right]$ & {$\left[\begin{array}{c}\text { jpmusu } \\
\text { gold }\end{array}\right.$} & $\begin{array}{c}\text { jpmusu } \\
1.00\end{array}$ & $\left.\begin{array}{c}\text { gold } \\
0.32 \\
1.00\end{array}\right]$ & $\begin{array}{c}\text { jpmusu } \\
\text { gold }\end{array}$ & $\begin{array}{c}\text { jpmusu } \\
0.5053 \\
(1.0743 e-01) \\
\end{array}$ & $\begin{array}{c}\text { gold } \\
-0.0836 \\
(2.79972-03) \\
0.5574 \\
(1.29780-01)\end{array}$ & $\begin{array}{c}\text { jpmusu } \\
\text { gold }\end{array}$ & $\begin{array}{c}j p m u s u \\
0.4937 \\
(3.2175 e-02) \\
\end{array}$ & $\begin{array}{c}\text { gold } \\
0.1528 \\
(1.5456-03) \\
0.4653 \\
(2.88193-02)\end{array}$ & {$\left[\begin{array}{c}0.9627 \\
(4.3319 e-04) \\
0.0373\end{array}\right.$} & {$\left[\begin{array}{c}0.0362 \\
(2.262020-04) \\
0.9638\end{array}\right]$} \\
\hline silver & {$\left[\begin{array}{c}\text { jpmusu } \\
\text { silver }\end{array}\right.$} & $\begin{array}{c}\text { jpmusu } \\
1.00\end{array}$ & $\left.\begin{array}{r}\text { silver } \\
0.16 \\
1.00\end{array}\right]$ & {$\left[\begin{array}{c}\text { jpmusu } \\
\text { silver }\end{array}\right.$} & $\begin{array}{c}\text { jpmusu } \\
1.00\end{array}$ & $\left.\begin{array}{c}\text { silver } \\
-0.14 \\
1.00\end{array}\right]$ & $\begin{array}{l}\text { jpmusu } \\
\text { silver }\end{array}$ & $\begin{array}{c}\text { jpmusu } \\
0.4774 \\
(5.0076 e-02) \\
\end{array}$ & $\begin{array}{c}\text { silver } \\
0.0752 \\
(2.6380-03) \\
0.4685 \\
(3.7662 e-02)\end{array}$ & $\begin{array}{c}\text { jpmusu } \\
\text { silver }\end{array}$ & $\begin{array}{c}p m u s u \\
0.5217 \\
(5.6135 e-01)\end{array}$ & $\begin{array}{c}\text { silver } \\
-0.0753 \\
(1.9136-02) \\
0.5343 \\
(6.25040-01)\end{array}$ & {$\left[\begin{array}{c}0.9894 \\
\left(\begin{array}{c}6.9317 e-05) \\
0.0106\end{array}\right.\end{array}\right.$} & $\left.\begin{array}{c}0.0119 \\
(5.87828205) \\
0.9881\end{array}\right]$ \\
\hline platinum & $\begin{array}{c}\text { jpmusu } \\
\text { plat. }\end{array}$ & $\begin{array}{c}\text { jpmusu } \\
1.00\end{array}$ & $\left.\begin{array}{c}\text { plat. } \\
0.11 \\
1.00\end{array}\right]$ & {$\left[\begin{array}{c}\text { jpmusu } \\
\text { plat. }\end{array}\right.$} & $\begin{array}{c}\text { jpmusu } \\
1.00\end{array}$ & $\left.\begin{array}{c}\text { plat. } \\
-0.20 \\
1.00\end{array}\right]$ & $\begin{array}{c}\text { jpmusu } \\
\text { plat. }\end{array}$ & $\begin{array}{c}p m u s u \\
0.4722 \\
(8.0716 e-03)\end{array}$ & $\begin{array}{c}\text { plat. } \\
0.0532 \\
(3.87092-04) \\
0.4923 \\
(1.2739 e-02)\end{array}$ & $\begin{array}{c}\text { jpmusu } \\
\text { plat. }\end{array}$ & $\begin{array}{c}\text { jpmusu } \\
0.5268 \\
(7.4769 e-01) \\
\end{array}$ & $\begin{array}{c}\text { plat. } \\
-0.1050 \\
(4.21530-02) \\
0.5147 \\
(6.9781 e-01)\end{array}$ & {$\left[\begin{array}{c}0.9921 \\
(3.02316-05) \\
0.0079\end{array}\right.$} & $\left.\begin{array}{c}0.0084 \\
(2.22996-05) \\
0.9916\end{array}\right]$ \\
\hline palladium & $\begin{array}{c}\text { jpmusu } \\
\text { pall. }\end{array}$ & $\begin{array}{l}\text { jpmusu } \\
1.00\end{array}$ & $\left.\begin{array}{c}\text { pall. } \\
0.02 \\
1.00\end{array}\right]$ & $\begin{array}{c}\text { jpmusu } \\
\text { pall. }\end{array}$ & $\begin{array}{c}\text { jpmusu } \\
1.00\end{array}$ & $\left.\begin{array}{c}\text { pall. } \\
-0.20 \\
1.00\end{array}\right]$ & $\begin{array}{c}\text { jpmusu } \\
\text { pall. }\end{array}$ & $\begin{array}{c}\text { jpmusu } \\
0.4280 \\
(7.4773 e-01)\end{array}$ & $\begin{array}{c}\text { pall. } \\
0.0098 \\
(4.0580-03) \\
0.4245 \\
(1.1125 e+01) \\
\end{array}$ & $\begin{array}{c}\text { jpmusu } \\
\text { pall. }\end{array}$ & $\begin{array}{c}\text { pmusu } \\
0.5710 \\
(8.9093 e+00) \\
\end{array}$ & $\begin{array}{c}\text { pall. } \\
-0.1173 \\
(2.181112-01) \\
0.5756 \\
(9.76366+00)\end{array}$ & {$\left[\begin{array}{c}0.9988 \\
(2.4103 e-05) \\
0.0012\end{array}\right.$} & {$\left[\begin{array}{c}0.0019 \\
(2.4220 e-04) \\
0.9981\end{array}\right]$} \\
\hline alluminium & $\begin{array}{c}\text { jpmusu } \\
\text { allu. }\end{array}$ & $\begin{array}{c}\text { jpmusu } \\
1.00\end{array}$ & $\left.\begin{array}{c}\text { allu. } \\
0.04 \\
1.00\end{array}\right]$ & $\begin{array}{c}\text { jpmusu } \\
\text { allu. }\end{array}$ & $\begin{array}{c}\text { jpmusu } \\
1.00\end{array}$ & $\left.\begin{array}{c}\text { allu. } \\
-0.29 \\
1.00\end{array}\right]$ & $\begin{array}{c}\text { jpmusu } \\
\text { allu. }\end{array}$ & $\begin{array}{c}p m u s u \\
0.4801 \\
(4.2301 e-02) \\
\end{array}$ & $\begin{array}{c}\text { allu. } \\
0.0217 \\
(3.4732 e-05) \\
0.4965 \\
(8.5772 e-02) \\
\end{array}$ & $\begin{array}{c}\text { jpmusu } \\
\text { allu. }\end{array}$ & $\begin{array}{c}p \text { musu } \\
0.5189 \\
(3.1694 e-01) \\
\end{array}$ & $\begin{array}{c}\text { allu. } \\
-0.1527 \\
(2.64344-02) \\
0.5281 \\
(3.2684 e-01) \\
\end{array}$ & {$\left[\begin{array}{c}0.9940 \\
(8.5897 e-05) \\
0.0060\end{array}\right.$} & $\left.\begin{array}{c}0.0061 \\
\left(\begin{array}{c}2.34616-04) \\
0.9939\end{array}\right]\end{array}\right]$ \\
\hline copper & $\begin{array}{l}\text { jpmusu } \\
\text { copper }\end{array}$ & $\begin{array}{c}\text { jpmusu } \\
1.00\end{array}$ & $\left.\begin{array}{c}\text { copper } \\
0.03 \\
1.00\end{array}\right]$ & {$\left[\begin{array}{l}\text { jpmusu } \\
\text { copper }\end{array}\right.$} & $\begin{array}{c}\text { jpmusu } \\
1.00\end{array}$ & $\left.\begin{array}{c}\text { copper } \\
-0.32 \\
1.00\end{array}\right]$ & $\begin{array}{l}\text { jpmusu } \\
\text { copper }\end{array}$ & $\begin{array}{c}p \text { musu } \\
0.4507 \\
(4.7167 e-02) \\
\end{array}$ & $\begin{array}{c}\text { copper } \\
0.0139 \\
(5.4979 e-05) \\
0.4560 \\
(3.2939 e-02)\end{array}$ & $\begin{array}{l}\text { jpmusu } \\
\text { copper }\end{array}$ & $\begin{array}{c}\text { jpmusu } \\
0.5484 \\
(8.5442 e-02) \\
\end{array}$ & $\begin{array}{c}\text { copper } \\
-0.1720 \\
(1.25988-02) \\
0.5431 \\
(8.7049 e-02)\end{array}$ & {$\left[\begin{array}{c}0.9971 \\
(9.0135 e-06) \\
0.0029\end{array}\right.$} & $\left.\begin{array}{c}0.0029 \\
(5.57832 e-06) \\
0.9971\end{array}\right]$ \\
\hline nickel & {$\left[\begin{array}{c}\text { jpmusu } \\
\text { nickel }\end{array}\right.$} & $\begin{array}{c}\text { jpmusu } \\
1.00\end{array}$ & $\left.\begin{array}{c}\text { nickel } \\
0.06 \\
1.00\end{array}\right]$ & {$\left[\begin{array}{c}\text { jpmusu } \\
\text { nickel }\end{array}\right.$} & $\begin{array}{c}\text { jpmusu } \\
1.00\end{array}$ & $\left.\begin{array}{c}\text { nickel } \\
-0.23 \\
1.00\end{array}\right]$ & $\begin{array}{c}\text { jpmusu } \\
\text { nickel }\end{array}$ & $\begin{array}{c}\text { jpmusu } \\
0.4246 \\
(3.8283 e-02)\end{array}$ & $\begin{array}{c}\text { nickel } \\
0.0241 \\
(1.8662 e-04) \\
0.43434 \\
(239998-02)\end{array}$ & $\begin{array}{c}\text { jpmusu } \\
\text { nickel }\end{array}$ & $\begin{array}{c}p m u s u \\
0.5744 \\
(6.9734 e-02) \\
\end{array}$ & $\begin{array}{c}\text { nickel } \\
-0.1318 \\
(1.2480-02) \\
0.5657 \\
(7.5620-02)\end{array}$ & {$\left[\begin{array}{c}0.9973 \\
(9.29077-06) \\
0.0027\end{array}\right.$} & $\left.\begin{array}{c}(8.0035 \\
(8.876-055) \\
0.9965\end{array}\right]$ \\
\hline lead & $\begin{array}{c}\text { jpmusu } \\
\text { lead }\end{array}$ & $\begin{array}{c}\text { jpmusu } \\
1.00\end{array}$ & $\left.\begin{array}{l}\text { lead } \\
0.03 \\
1.00\end{array}\right]$ & {$\left[\begin{array}{c}\text { jpmusu } \\
\text { lead }\end{array}\right.$} & $\begin{array}{c}\text { jpmusu } \\
1.00\end{array}$ & $\left.\begin{array}{c}\text { lead } \\
-0.29 \\
1.00\end{array}\right]$ & $\begin{array}{c}\text { jpmusu } \\
\text { lead }\end{array}$ & $\begin{array}{c}j p m u s u \\
0.5345 \\
(4.0761 e+00) \\
\end{array}$ & $\begin{array}{c}\text { lead } \\
0.0172 \\
(4.8212-03) \\
0.5511 \\
(4.3337 e+00)\end{array}$ & $\begin{array}{c}\text { jpmusu } \\
\text { lead }\end{array}$ & $\begin{array}{c}p m u s u \\
0.4645 \\
(1.2626 e+00) \\
\end{array}$ & $\begin{array}{c}\text { lead } \\
-0.1307 \\
(1.0254-0.01) \\
0.4488 \\
(1.17288+00)\end{array}$ & {$\left[\begin{array}{c}0.9982 \\
(3.338320-05) \\
0.0018\end{array}\right.$} & $\left.\begin{array}{c}0.0012 \\
(3.67696-05) \\
0.9988\end{array}\right]$ \\
\hline tin & {$\left[\begin{array}{c}\text { jpmusu } \\
\text { tin }\end{array}\right.$} & $\begin{array}{c}\text { jpmusu } \\
1.00\end{array}$ & $\left.\begin{array}{c}\operatorname{tin} \\
-0.01 \\
1.00\end{array}\right]$ & {$\left[\begin{array}{c}\text { jpmusu } \\
\text { tin }\end{array}\right.$} & $\begin{array}{c}\text { jpmusu } \\
1.00\end{array}$ & $\left.\begin{array}{c}\operatorname{tin} \\
-0.29 \\
1.00\end{array}\right]$ & $\begin{array}{c}\text { jpmusu } \\
\text { tin }\end{array}$ & $\begin{array}{c}\text { jpmusu } \\
0.5956 \\
(8.2233 e-01)\end{array}$ & $\begin{array}{c}\text { tin } \\
-0.0088 \\
(7.42822-04) \\
0.6019 \\
(2.6659 e+00)\end{array}$ & $\begin{array}{c}\text { jpmusu } \\
\text { tin }\end{array}$ & $\begin{array}{c}\text { jpmusu } \\
0.4035 \\
(3.3463 e+00)\end{array}$ & $\begin{array}{c}\operatorname{tin} \\
-0.1119 \\
(3.28699-01) \\
0.4070 \\
(3.3793 e+00)\end{array}$ & {$\left[\begin{array}{c}0.9989 \\
\left(\begin{array}{c}4.56100-05) \\
0.0011\end{array}\right.\end{array}\right.$} & $\left.\begin{array}{c}0.0008 \\
(4.0567 e-06) \\
0.9992\end{array}\right]$ \\
\hline zinc & $\begin{array}{c}\text { jpmusu } \\
\text { zinc }\end{array}$ & $\begin{array}{l}\text { jpmusu } \\
1.00\end{array}$ & $\left.\begin{array}{c}z i n c \\
0.05 \\
1.00\end{array}\right]$ & {$\left[\begin{array}{c}\text { jpmusu } \\
\text { zinc }\end{array}\right.$} & $\begin{array}{c}j p m u s u \\
1.00\end{array}$ & $\left.\begin{array}{c}z i n c \\
-0.32 \\
1.00\end{array}\right]$ & $\begin{array}{c}\text { jpmusu } \\
\text { zinc }\end{array}$ & $\begin{array}{c}p m \text { musu } \\
0.5074 \\
(4.0591 e-02)\end{array}$ & $\begin{array}{c}z i n c \\
0.0268 \\
(5.6036-04) \\
0.5317 \\
(2.6424 e-02) \\
\end{array}$ & $\begin{array}{c}\text { jpmusu } \\
\text { zinc }\end{array}$ & $\begin{array}{c}p \text { musu } \\
0.4917 \\
(1.9648 e-01) \\
\end{array}$ & $\begin{array}{c}z i n c \\
-0.1510 \\
(1.6293 e-02) \\
0.4669 \\
(1.7800 e-01)\end{array}$ & {$\left[\begin{array}{c}0.9847 \\
(6.1330 e-04) \\
0.0153\end{array}\right.$} & {$\left[\begin{array}{c}0.0145 \\
(9.5012 e-04) \\
0.9855\end{array}\right]$} \\
\hline corn & $\begin{array}{c}\text { jpmusu } \\
\text { corn }\end{array}$ & $\begin{array}{c}\text { jpmusu } \\
1.00\end{array}$ & $\left.\begin{array}{c}\text { corn } \\
0.05 \\
1.00\end{array}\right]$ & {$\left[\begin{array}{c}j p m u s u \\
\text { corn }\end{array}\right.$} & $\begin{array}{c}\text { jpmusu } \\
1.00\end{array}$ & $\left.\begin{array}{c}\text { corn } \\
-0.21 \\
1.00\end{array}\right]$ & $\begin{array}{c}\text { jpmusu } \\
\text { corn }\end{array}$ & $\begin{array}{c}j p m u s u \\
0.4836 \\
(2.9463 e+01)\end{array}$ & $\begin{array}{c}\text { corn } \\
0.0248 \\
(1.3888-01) \\
0.5069 \\
(2.0015 e+01) \\
\end{array}$ & $\begin{array}{c}\text { jpmusu } \\
\text { corn }\end{array}$ & $\begin{array}{c}\text { jpmusu } \\
0.5155 \\
(6.8164 e-01)\end{array}$ & $\begin{array}{c}c o r n \\
-0.1094 \\
(1.0912 e-02) \\
0.5217 \\
(7.18799 e-01)\end{array}$ & {$\left[\begin{array}{c}0.9742 \\
0.03982-02) \\
0.0258\end{array}\right.$} & $\left.\begin{array}{c}0.0264 \\
(4.96936-03) \\
0.9736\end{array}\right]$ \\
\hline soybeans & {$\left[\begin{array}{c}\text { jpmusu } \\
\text { soyb. }\end{array}\right.$} & $\begin{array}{c}\text { jpmusu } \\
1.00\end{array}$ & $\left.\begin{array}{r}\text { soyb. } \\
0.05 \\
1.00\end{array}\right]$ & {$\left[\begin{array}{c}\text { jpmusu } \\
\text { soyb. }\end{array}\right.$} & $\begin{array}{c}\text { jpmusu } \\
1.00\end{array}$ & $\left.\begin{array}{c}s o y b . \\
-0.24 \\
1.00\end{array}\right]$ & $\begin{array}{c}\text { jpmusu } \\
\text { soyb. }\end{array}$ & $\begin{array}{c}\text { jpmusu } \\
0.4526 \\
(1.6211 e-01) \\
\end{array}$ & $\begin{array}{c}\text { soyb. } \\
0.0246 \\
(1.3991 e-03) \\
0.4563 \\
(1.64786-01)\end{array}$ & $\begin{array}{c}\text { jpmusu } \\
\text { soyb. }\end{array}$ & $\begin{array}{c}\text { jpmusu } \\
0.5464 \\
(1.8621 e+00)\end{array}$ & $\begin{array}{c}\text { soyb. } \\
-0.1297 \\
(7.5874-02) \\
0.5502 \\
(1.7721 e+00)\end{array}$ & {$\left[\begin{array}{c}0.9999 \\
(1.0957 r-04) \\
0.0091\end{array}\right.$} & {$\left[\begin{array}{c}0.0107 \\
(7.7664 e-04) \\
0.9893\end{array}\right]$} \\
\hline soybean oil & {$\left[\begin{array}{c}\text { jpmusu } \\
\text { soyb. }\end{array}\right.$} & $\begin{array}{c}\text { jpmusu } \\
1.00\end{array}$ & $\left.\begin{array}{c}\text { soyb. } \\
0.02 \\
1.00\end{array}\right]$ & {$\left[\begin{array}{c}\text { jpmusu } \\
\text { soyb. }\end{array}\right.$} & $\begin{array}{c}\text { jpmusu } \\
1.00\end{array}$ & $\left.\begin{array}{c}s o y b . \\
-0.20 \\
1.00\end{array}\right]$ & $\begin{array}{c}\text { jpmusu } \\
\text { soyb. }\end{array}$ & $\begin{array}{c}\text { jpmusu } \\
0.3416 \\
(4.3154 e-02) \\
\end{array}$ & $\begin{array}{c}\text { soyb. } \\
0.0084 \\
(5.1359 e-05) \\
0.3514 \\
(3.2828 e-02)\end{array}$ & $\begin{array}{c}\text { jpmusu } \\
\text { soyb. }\end{array}$ & $\begin{array}{c}\text { jpmusu } \\
0.6574 \\
(9.6578 e-03) \\
\end{array}$ & $\begin{array}{c}\text { soyb. } \\
-0.1312 \\
(8.5324-04) \\
0.6556\end{array}$ & {$\left[\begin{array}{c}1.0000 \\
(6.4213 e-12) \\
0.0000\end{array}\right.$} & {$\left[\begin{array}{c}0.0010 \\
(2.8699-095) \\
0.9990\end{array}\right]$} \\
\hline wheat & {$\left[\begin{array}{l}\text { jpmusu } \\
\text { wheat }\end{array}\right.$} & $\begin{array}{c}\text { jpmusu } \\
1.00\end{array}$ & $\left.\begin{array}{c}\text { wheat } \\
0.07 \\
1.00\end{array}\right]$ & $\begin{array}{l}\text { jpmusu } \\
\text { wheat }\end{array}$ & $\begin{array}{c}\text { jpmusu } \\
1.00\end{array}$ & $\left.\begin{array}{c}\text { wheat } \\
-0.22 \\
1.00\end{array}\right]$ & $\begin{array}{l}\text { jpmusu } \\
\text { wheat }\end{array}$ & $\begin{array}{c}\text { jpmusu } \\
0.4950 \\
(1.4084 e+00) \\
\end{array}$ & $\begin{array}{c}\text { wheat } \\
0.0361 \\
(3.73010-02) \\
0.4998 \\
(1.4418 e+00)\end{array}$ & $\begin{array}{c}\text { jpmusu } \\
\text { wheat }\end{array}$ & $\begin{array}{c}\text { jpmusu } \\
0.5041 \\
(2.5671 e+00) \\
\end{array}$ & $\begin{array}{c}\text { wheat } \\
-0.1126 \\
(1.2134-02) \\
0.5099 \\
(2.6464 c+00)\end{array}$ & {$\left[\begin{array}{c}0.9851 \\
(2.77532-03) \\
0.0149\end{array}\right.$} & $\left.\begin{array}{c}0.0146 \\
(4.8672 e-03) \\
0.9854\end{array}\right]$ \\
\hline coffe & {$\left[\begin{array}{c}\text { jpmusu } \\
\text { coffe }\end{array}\right.$} & $\begin{array}{c}\text { jpmusu } \\
1.00\end{array}$ & $\left.\begin{array}{r}c o f f e \\
0.08 \\
1.00\end{array}\right]$ & $\begin{array}{c}\text { jpmusu } \\
\text { coffe }\end{array}$ & $\begin{array}{c}\text { jpmusu } \\
1.00\end{array}$ & $\left.\begin{array}{c}c o f f e \\
-0.18 \\
1.00\end{array}\right]$ & $\begin{array}{l}\text { jpmusu } \\
\text { coffe }\end{array}$ & $\begin{array}{c}p \text { musu } \\
0.4516 \\
(3.6565 e-02) \\
\end{array}$ & $\begin{array}{c}c o f f e \\
0.038 \\
(9.48780-055) \\
0.4771 \\
(2.9845 e-02) \\
\end{array}$ & $\begin{array}{l}\text { jpmusu } \\
\text { coffe }\end{array}$ & $\begin{array}{c}j p m u s u \\
0.5475 \\
(2.1850 e-02) \\
\end{array}$ & $\begin{array}{c}\text { coffee } \\
-0.0940 \\
(1.70555-04) \\
0.5229 \\
(2.0787 e-02)\end{array}$ & {$\left[\begin{array}{c}0.9992 \\
(1.2249 e-05) \\
0.0008\end{array}\right.$} & {$\left[\begin{array}{c}0.0009 \\
(1.63040-06) \\
0.9991\end{array}\right]$} \\
\hline cotton & {$\left[\begin{array}{l}\text { jpmusu } \\
\text { cotton }\end{array}\right.$} & $\begin{array}{c}\text { jpmusu } \\
1.00\end{array}$ & $\left.\begin{array}{c}\text { cotton } \\
0.01 \\
1.00\end{array}\right]$ & $\begin{array}{l}\text { jpmusu } \\
\text { cotton }\end{array}$ & $\begin{array}{c}\text { jpmusu } \\
1.00\end{array}$ & $\left.\begin{array}{c}\text { cotton } \\
-0.23 \\
1.00\end{array}\right]$ & $\begin{array}{l}\text { jpmusu } \\
\text { cotton }\end{array}$ & $\begin{array}{c}\text { jpmusu } \\
0.4908 \\
(6.1932 e-01) \\
\end{array}$ & $\begin{array}{c}\text { cotton } \\
0.0006 \\
(1.90766-04) \\
0.51161 \\
(6.7242 e-02) \\
\end{array}$ & $\begin{array}{l}\text { jpmusu } \\
\text { cotton }\end{array}$ & $\begin{array}{c}j p m u s u \\
0.5082 \\
(1.1368 e-01) \\
\end{array}$ & $\begin{array}{c}\text { cotton } \\
-0.1167 \\
(7.0623 e-03) \\
0.4987 \\
(1.1011 e-01)\end{array}$ & {$\left[\begin{array}{c}0.9823 \\
(2.17750-04) \\
0.0177\end{array}\right.$} & $\left.\begin{array}{c}0.0178 \\
(1.7564 e-04) \\
0.9822\end{array}\right]$ \\
\hline orange juice & {$\left[\begin{array}{c}\text { jpmusu } \\
\text { oran. }\end{array}\right.$} & $\begin{array}{c}\text { jpmusu } \\
1.00\end{array}$ & $\left.\begin{array}{c}\text { oran. } \\
0.05 \\
1.00\end{array}\right]$ & {$\left[\begin{array}{c}\text { jpmusu } \\
\text { oran. }\end{array}\right.$} & $\begin{array}{c}\text { jpmusu } \\
1.00\end{array}$ & $\left.\begin{array}{c}\text { oran. } \\
-0.13 \\
1.00\end{array}\right]$ & $\begin{array}{c}\text { jpmusu } \\
\text { oran. }\end{array}$ & $\begin{array}{c}\text { jpmusu } \\
0.4785 \\
(6.1301 e-02) \\
\end{array}$ & $\left.\begin{array}{c}\text { oran. } \\
0.0253 \\
(1.3565 e-03) \\
0.4753 \\
(1.875676 e-01)\end{array}\right]$ & $\begin{array}{l}\text { jpmusu } \\
\text { oran. }\end{array}$ & $\begin{array}{c}j p m u s u \\
0.5206 \\
(4.7237 e-02) \\
\end{array}$ & $\begin{array}{c}\text { oran. } \\
-0.0687 \\
(1.1992-0.3) \\
0.5293 \\
(6.05282-02)\end{array}$ & {$\left[\begin{array}{c}1.0000 \\
(2.37166-11) \\
0.0000\end{array}\right.$} & $\left.\begin{array}{c}0.0007 \\
(2.7194 e-04) \\
0.9993\end{array}\right]$ \\
\hline barely & {$\left[\begin{array}{c}\text { jpmusu } \\
\text { barely }\end{array}\right.$} & $\begin{array}{cc}\text { jpmusu } \\
1.00\end{array}$ & $\left.\begin{array}{c}\text { barely } \\
-0.04 \\
1.00\end{array}\right]$ & {$\left[\begin{array}{c}\text { jpmusu } \\
\text { barely }\end{array}\right.$} & $\begin{array}{c}\text { jpmusu } \\
1.00\end{array}$ & $\left.\begin{array}{c}\text { barely } \\
0.09 \\
1.00\end{array}\right]$ & $\begin{array}{l}\text { jpmusu } \\
\text { barely }\end{array}$ & $\begin{array}{c}\text { jpmusu } \\
0.4962 \\
(3.0984 e-02) \\
\end{array}$ & $\begin{array}{c}\text { barely } \\
-0.0220 \\
(7.1 .3920-05) \\
0.5344 \\
(1.33132-02)\end{array}$ & $\begin{array}{l}\text { jpmusu } \\
\text { barely }\end{array}$ & $\begin{array}{c}\text { jpmusu } \\
0.5029 \\
(6.6089 e-02) \\
\end{array}$ & $\begin{array}{c}\text { barely } \\
0.0499 \\
(5.2899-05) \\
0.4756 \\
(4.64356-02)\end{array}$ & {$\left[\begin{array}{c}0.9821 \\
(1.1014+04) \\
0.0179\end{array}\right.$} & $\left.\begin{array}{c}0.0184 \\
(8.3387 e-05) \\
0.9816\end{array}\right]$ \\
\hline oat & {$\left[\begin{array}{c}\text { jpmusu } \\
\text { oat }\end{array}\right.$} & $\begin{array}{c}\text { jpmusu } \\
1.00\end{array}$ & $\left.\begin{array}{c}\text { oat } \\
-0.04 \\
1.00\end{array}\right]$ & {$\left[\begin{array}{c}\text { jpmusu } \\
\text { oat }\end{array}\right.$} & $\begin{array}{c}\text { jpmusu } \\
1.00\end{array}$ & $\left.\begin{array}{c}\text { oat } \\
-0.13 \\
1.00\end{array}\right]$ & $\begin{array}{c}\text { jpmusu } \\
\text { oat }\end{array}$ & $\begin{array}{c}\text { jpmusu } \\
0.4974 \\
(5.8555 e-02)\end{array}$ & $\begin{array}{c}\text { oat } \\
-0.0220 \\
(8.34572-05) \\
0.5029 \\
(1.108990-01)\end{array}$ & $\begin{array}{c}\text { jpmusu } \\
\text { oat }\end{array}$ & $\begin{array}{c}\text { jpmusu } \\
0.5017 \\
(3.4523 e-02) \\
\end{array}$ & $\begin{array}{c}\text { oat } \\
-0.0655 \\
(2.73920-05) \\
0.5037 \\
(49679-02)\end{array}$ & {$\left[\begin{array}{c}0.9932 \\
(8.9257 e-05) \\
0.0068\end{array}\right.$} & $\left.\begin{array}{c}0.0069 \\
(2.8876 e-05) \\
0.9931\end{array}\right]$ \\
\hline rice & {$\left[\begin{array}{c}\text { jpmusu } \\
\text { rice }\end{array}\right.$} & $\begin{array}{c}\text { jpmusu } \\
1.00\end{array}$ & $\left.\begin{array}{l}\text { rice } \\
0.07 \\
1.00\end{array}\right]$ & {$\left[\begin{array}{c}\text { jpmusu } \\
\text { rice }\end{array}\right.$} & $\begin{array}{c}\text { jpmusu } \\
1.00\end{array}$ & $\left.\begin{array}{c}\text { rice } \\
-0.09 \\
1.00\end{array}\right]$ & $\begin{array}{c}\text { jpmusu } \\
\text { rice }\end{array}$ & $\begin{array}{c}p m \text { musu } \\
0.4827 \\
(1.6950 e-01)\end{array}$ & $\begin{array}{c}\text { rice } \\
0.0343 \\
(9.3200-04) \\
0.4985 \\
(1.9440-01)\end{array}$ & $\begin{array}{c}\text { jpmusu } \\
\text { rice }\end{array}$ & $\begin{array}{c}p m u s u \\
0.5163 \\
(1.3625 e-01) \\
\end{array}$ & $\begin{array}{c}\text { rice } \\
-0.0463 \\
(1.2638-03) \\
0.5275 \\
(1.43999-01)\end{array}$ & {$\left[\begin{array}{c}0.9874 \\
(8.02500-04) \\
0.0126\end{array}\right.$} & $\left.\begin{array}{c}0.0130 \\
(5.1622 e-04) \\
0.9870\end{array}\right]$ \\
\hline palm oil & {$\left[\begin{array}{l}\text { jpmusu } \\
\text { palm. }\end{array}\right.$} & $\begin{array}{c}\text { jpmusu } \\
1.00\end{array}$ & $\left.\begin{array}{c}\text { palm. } \\
-0.06 \\
1.00\end{array}\right]$ & $\begin{array}{l}\text { jpmusu } \\
\text { palm. }\end{array}$ & $\begin{array}{c}\text { jpmusu } \\
1.00\end{array}$ & $\left.\begin{array}{c}\text { palm. } \\
-0.06 \\
1.00\end{array}\right]$ & $\begin{array}{l}\text { jpmusu } \\
\text { palm. }\end{array}$ & $\begin{array}{c}\text { jpmusu } \\
0.5004 \\
(3.5819 e-05)\end{array}$ & $\begin{array}{c}\text { palm. } \\
-0.0297 \\
(2.61010-05) \\
0.4992 \\
(6.06962-05)\end{array}$ & $\begin{array}{l}\text { jpmusu } \\
\text { palm. }\end{array}$ & $\begin{array}{c}\text { jpmusu } \\
0.4987 \\
(8.0696 e-04) \\
\end{array}$ & $\begin{array}{c}\text { palm. } \\
-0.0296 \\
(1.80829-04) \\
0.4975 \\
(6.2744 e-04)\end{array}$ & {$\left[\begin{array}{c}0.9934 \\
(2.4437 e-03) \\
0.0066\end{array}\right.$} & $\left.\begin{array}{c}0.0066 \\
(1.1382 e-06) \\
0.9934\end{array}\right]$ \\
\hline cocao & {$\left[\begin{array}{c}\text { jpmusu } \\
\text { cocao }\end{array}\right.$} & $\begin{array}{c}\text { jpmusu } \\
1.00\end{array}$ & $\left.\begin{array}{c}\text { cocao } \\
0.00 \\
1.00\end{array}\right]$ & $\begin{array}{c}\text { jpmusu } \\
\text { сосао }\end{array}$ & $\begin{array}{c}\text { jpmusu } \\
1.00\end{array}$ & $\left.\begin{array}{c}c o c a o \\
-0.19 \\
1.00\end{array}\right]$ & $\begin{array}{c}\text { jpmusu } \\
\text { сосао }\end{array}$ & $\begin{array}{c}j p m u s u \\
0.5197 \\
(4.6699 e-02)\end{array}$ & $\left.\begin{array}{c}c \text { cocao } \\
0.0007 \\
(1.18350-04) \\
0.5311 \\
(7.4659 e-02)\end{array}\right]$ & $\begin{array}{c}\text { jpmusu } \\
\text { сосао }\end{array}$ & $\begin{array}{c}\text { jpmusu } \\
0.4794 \\
(5.4160 e-02) \\
\end{array}$ & $\begin{array}{c}c \text { cocao } \\
-0.0912 \\
(5.78744-04) \\
0.4657 \\
(4.8347 e-02)\end{array}$ & {$\left[\begin{array}{c}0.9938 \\
(8.5592 e-05) \\
0.0062\end{array}\right.$} & $\left.\begin{array}{c}0.0056 \\
(9.4105 e-06) \\
0.9944\end{array}\right]$ \\
\hline sugar & {$\left[\begin{array}{c}\text { jpmusu } \\
\text { sugar }\end{array}\right.$} & $\begin{array}{c}\text { jpmusu } \\
1.00\end{array}$ & $\left.\begin{array}{r}\text { sugar } \\
0.07 \\
1.00\end{array}\right]$ & $\begin{array}{l}\text { jpmusu } \\
\text { sugar }\end{array}$ & $\begin{array}{c}\text { jpmusu } \\
1.00\end{array}$ & $\left.\begin{array}{c}\text { sugar } \\
-0.14 \\
1.00\end{array}\right]$ & $\begin{array}{l}\text { jpmusu } \\
\text { sugar }\end{array}$ & $\begin{array}{c}\text { jpmusu } \\
0.4520 \\
(8.6172 e-01) \\
\end{array}$ & \begin{tabular}{|c|} 
sugar \\
0.0327 \\
$(8.9565-03)$ \\
0.4602 \\
$(1.2563 e+00)$
\end{tabular} & $\begin{array}{c}\text { jpmusu } \\
\text { sugar }\end{array}$ & $\begin{array}{c}\text { jpmusu } \\
0.5471 \\
(1.2300 e-01) \\
\end{array}$ & $\begin{array}{c}\text { sugar } \\
-0.0793 \\
(6.1409-03) \\
0.5550 \\
(1.265580-01)\end{array}$ & {$\left[\begin{array}{c}0.9956 \\
(1.547770-05) \\
0.0044\end{array}\right.$} & $\left.\begin{array}{c}0.0047 \\
(2.2200 e-05) \\
0.9953\end{array}\right]$ \\
\hline lumber & $\begin{array}{l}\text { jpmusu } \\
\text { lumber }\end{array}$ & $\begin{array}{c}\text { jpmusu } \\
1.00\end{array}$ & $\left.\begin{array}{c}\text { lumber } \\
-0.12 \\
1.00\end{array}\right]$ & {$\left[\begin{array}{l}\text { jpmusu } \\
\text { lumber }\end{array}\right.$} & $\begin{array}{c}\text { jpmusu } \\
1.00\end{array}$ & $\left.\begin{array}{c}\text { lumber } \\
-0.02 \\
1.00\end{array}\right]$ & $\begin{array}{l}\text { jpmusu } \\
\text { lumber }\end{array}$ & $\begin{array}{c}\text { jpmusu } \\
0.5131 \\
\left(4.6363 e^{-02)}\right. \\
\end{array}$ & 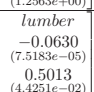 & $\begin{array}{l}\text { jpmusu } \\
\text { lumber }\end{array}$ & $\begin{array}{c}\text { jpmusu } \\
0.4860 \\
(4.4172 e-01) \\
\end{array}$ & 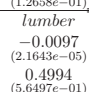 & {$\left[\begin{array}{c}0.9819 \\
(2.0041 e-04) \\
0.0181\end{array}\right.$} & $\left.\begin{array}{c}0.0183 \\
(2.5814 e-05) \\
0.9817\end{array}\right]$ \\
\hline sunflower & {$\left[\begin{array}{l}\text { jpmusu } \\
\text { sunf. }\end{array}\right.$} & $\begin{array}{c}\text { jpmusu } \\
1.00\end{array}$ & $\left.\begin{array}{c}\operatorname{sunf} . \\
-0.08 \\
1.00\end{array}\right]$ & $\begin{array}{c}\text { jpmusu } \\
\text { sunf. }\end{array}$ & $\begin{array}{c}\text { jpmusu } \\
1.00\end{array}$ & $\left.\begin{array}{r}\operatorname{sunf} . \\
0.06 \\
1.00\end{array}\right]$ & $\begin{array}{l}\text { jpmusu } \\
\text { sunf. }\end{array}$ & $\begin{array}{c}\text { jpmusu } \\
0.4949 \\
(5.1528 e-01) \\
\end{array}$ & $\begin{array}{c}\text { sunf. } \\
-0.0374 \\
(1.2066-03) \\
0.4845 \\
(5.4934 c-01)\end{array}$ & $\begin{array}{c}\text { jpmusu } \\
\text { sunf. }\end{array}$ & $\begin{array}{c}\text { jpmusu } \\
0.5041 \\
(8.0267 e-01) \\
\end{array}$ & $\begin{array}{c}\text { sunf. } \\
0.0291 \\
(2.26732-03) \\
0.5230 \\
(5.04750-01)\end{array}$ & {$\left[\begin{array}{c}0.9947 \\
(1.375350-04) \\
0.0053\end{array}\right.$} & $\left.\begin{array}{c}0.0048 \\
(6.7415 e-05) \\
0.9952\end{array}\right]$ \\
\hline lean hogs & {$\left[\begin{array}{c}\text { jpmusu } \\
\text { lean. }\end{array}\right.$} & $\begin{array}{c}\text { jpmusu } \\
1.00\end{array}$ & $\left.\begin{array}{c}\text { lean. } \\
-0.06 \\
1.00\end{array}\right]$ & {$\left[\begin{array}{c}\text { jpmusu } \\
\text { lean. }\end{array}\right.$} & $\begin{array}{c}\text { jpmusu } \\
1.00\end{array}$ & $\left.\begin{array}{c}\text { lean. } \\
-0.06 \\
1.00\end{array}\right]$ & $\begin{array}{c}\text { jpmusu } \\
\text { lean. }\end{array}$ & $\begin{array}{c}\text { jpmusu } \\
0.5004 \\
(1.6645 e-02)\end{array}$ & $\begin{array}{c}\text { lean. } \\
-0.0325 \\
(4.75312-06) \\
0.5028 \\
(8.03432-03)\end{array}$ & $\begin{array}{c}\text { jpmusu } \\
\text { lean. }\end{array}$ & $\begin{array}{c}j p m u s u \\
0.4987 \\
(3.6520 e-02) \\
\end{array}$ & $\begin{array}{c}\text { lean. } \\
-0.0324 \\
(1.1095 e-03) \\
0.5011 \\
(3.68800 e-02)\end{array}$ & {$\left[\begin{array}{c}0.9934 \\
(3.09990-01) \\
0.0066\end{array}\right.$} & $\left.\begin{array}{c}0.00666 \\
(7.3696 e-06) \\
0.9934\end{array}\right]$ \\
\hline live cattle & {$\left[\begin{array}{c}\text { jpmusu } \\
\text { live. }\end{array}\right.$} & $\begin{array}{c}\text { jpmusu } \\
1.00\end{array}$ & $\left.\begin{array}{c}\text { live. } \\
-0.01 \\
1.00\end{array}\right]$ & $\begin{array}{l}\text { jpmusu } \\
\text { live. }\end{array}$ & $\begin{array}{c}\text { jpmusu } \\
1.00\end{array}$ & $\left.\begin{array}{c}\text { live. } \\
-0.19 \\
1.00\end{array}\right]$ & $\begin{array}{c}\text { jpmusu } \\
\text { live. }\end{array}$ & $\begin{array}{c}\text { jpmusu } \\
0.4988 \\
(1.3121 e+00)\end{array}$ & $\begin{array}{c}\text { live. } \\
-0.0050 \\
(5.8658-05) \\
0.4968 \\
(1.1555 e+00)\end{array}$ & $\begin{array}{c}\text { jpmusu } \\
\text { live. }\end{array}$ & $\begin{array}{c}\text { jpmusu } \\
0.5003 \\
(4.5260 e-02) \\
\end{array}$ & $\begin{array}{c}\text { live. } \\
-0.0940 \\
(1.7650-0.03) \\
0.4976 \\
(3.2933-02)\end{array}$ & {$\left[\begin{array}{c}0.9829 \\
(7.2341 e-04) \\
0.0171\end{array}\right.$} & $\left.\begin{array}{c}0.0170 \\
(3.3098 e-04) \\
0.9830\end{array}\right]$ \\
\hline feeder cattle & {$\left[\begin{array}{c}\text { jpmusu } \\
\text { feed. }\end{array}\right.$} & $\begin{array}{c}\text { jpmusu } \\
1.00\end{array}$ & $\left.\begin{array}{r}\text { feed. } . \\
0.03 \\
1.00\end{array}\right]$ & $\begin{array}{c}\text { jpmusu } \\
\text { feed. }\end{array}$ & $\begin{array}{c}\text { jpmusu } \\
1.00\end{array}$ & $\left.\begin{array}{c}\text { feed. } \\
-0.17 \\
1.00\end{array}\right]$ & $\begin{array}{c}\text { jpmusu } \\
\text { feed. }\end{array}$ & $\begin{array}{c}\text { jpmusu } \\
0.4953 \\
(3.4835 e-02)\end{array}$ & $\begin{array}{c}\text { feed. } \\
0.0127 \\
(9.7730 e-05) \\
0.5048 \\
(3.6189 e-02) \\
\end{array}$ & $\begin{array}{c}\text { jpmusu } \\
\text { feed. }\end{array}$ & $\begin{array}{c}\text { jpmusu } \\
0.5038 \\
(5.8327 e-02) \\
\end{array}$ & $\begin{array}{c}\text { feed. } \\
-0.081 \\
(3.85086-04) \\
0.5064 \\
(5.5869 e-02) \\
\end{array}$ & {$\left[\begin{array}{c}0.9765 \\
(7.2171 e-04) \\
0.0235\end{array}\right.$} & $\left.\begin{array}{c}0.02222 \\
(6.02686-05) \\
0.9768\end{array}\right]$ \\
\hline
\end{tabular}



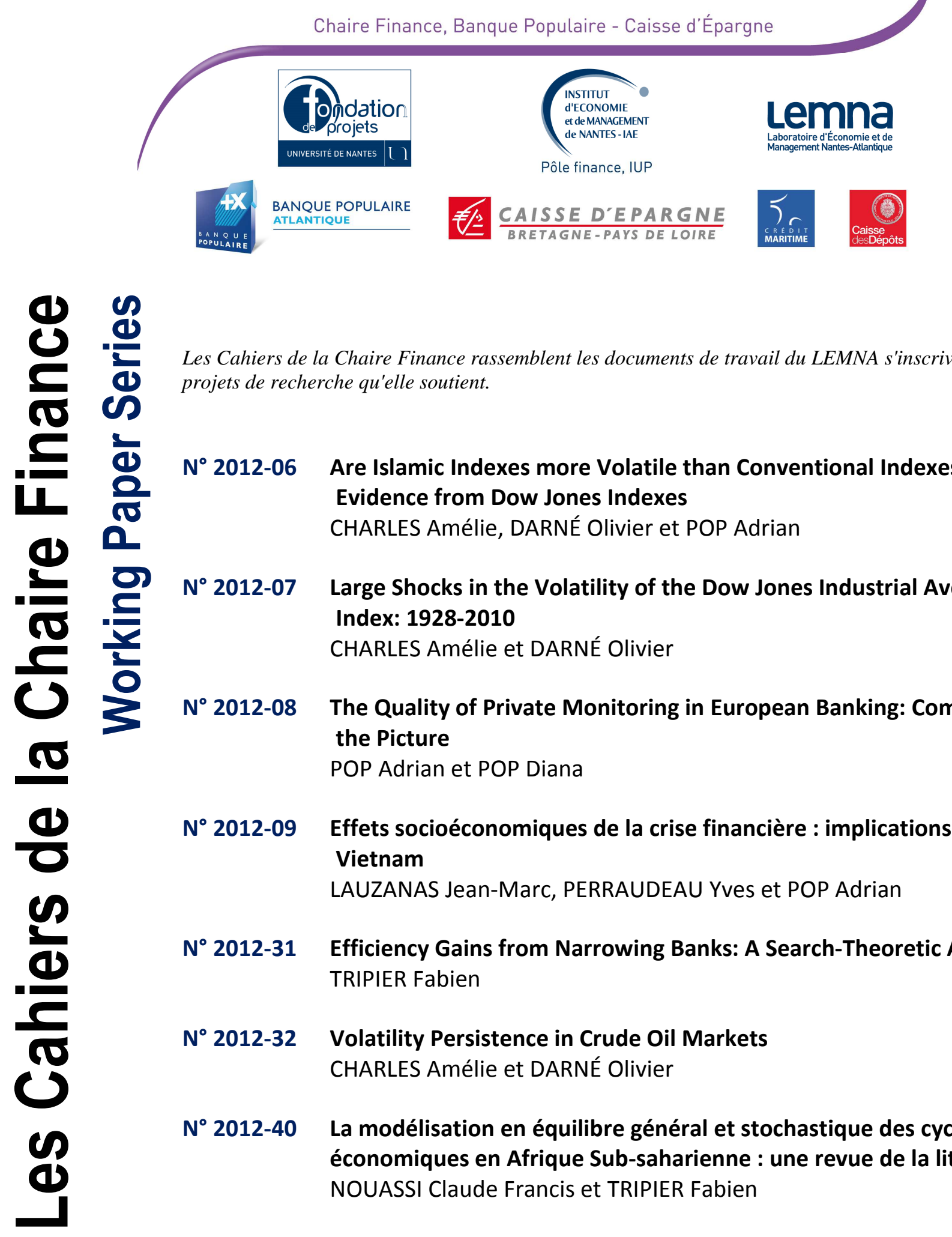

Les Cahiers de la Chaire Finance rassemblent les documents de travail du LEMNA s'inscrivant dans des projets de recherche qu'elle soutient.
$\mathbf{N}^{\circ}$ 2012-06 Are Islamic Indexes more Volatile than Conventional Indexes? Evidence from Dow Jones Indexes
CHARLES Amélie, DARNÉ Olivier et POP Adrian
$N^{\circ}$ 2012-07 Large Shocks in the Volatility of the Dow Jones Industrial Average Index: 1928-2010
CHARLES Amélie et DARNÉ Olivier
$\mathbf{N}^{\circ}$ 2012-08 The Quality of Private Monitoring in European Banking: Completing the Picture
POP Adrian et POP Diana
$\mathbf{N}^{\circ}$ 2012-09 Effets socioéconomiques de la crise financière : implications pour le Vietnam
LAUZANAS Jean-Marc, PERRAUDEAU Yves et POP Adrian
N² 2012-31 Efficiency Gains from Narrowing Banks: A Search-Theoretic Approach TRIPIER Fabien
$\mathbf{N}^{\circ}$ 2012-32 Volatility Persistence in Crude Oil Markets CHARLES Amélie et DARNÉ Olivier

$N^{\circ}$ 2012-40 La modélisation en équilibre général et stochastique des cycles économiques en Afrique Sub-saharienne : une revue de la littérature NOUASSI Claude Francis et TRIPIER Fabien

Les opinions exposées dans ce document n'engagent que les auteurs. Ceux-ci assument la responsabilité de toute erreur ou omission.

La Chaire Finance est une initiative de la Banque Populaire Atlantique, la Caisse d'Epargne Bretagne-Pays de Loire, la Caisse des Dépôts, du Crédit Maritime et de l'Université de Nantes, sous l'égide de la Fondation de Projets de I'Université de Nantes.

Site web : http://www.univ-nantes.fr/fondation/chairefinance

\section{Contact}

Chaire Finance, Banque Populaire - Caisse d'Epargne

IEMN-IAE, Chemin de Censive du Tertre - BP 52231

44322 Nantes cedex 3

Tél : +33 (0)2 40141660

Fax : +33(0)2 40141650

Email : Flavie.Chamard-Gueret@univ-nantes.fr 

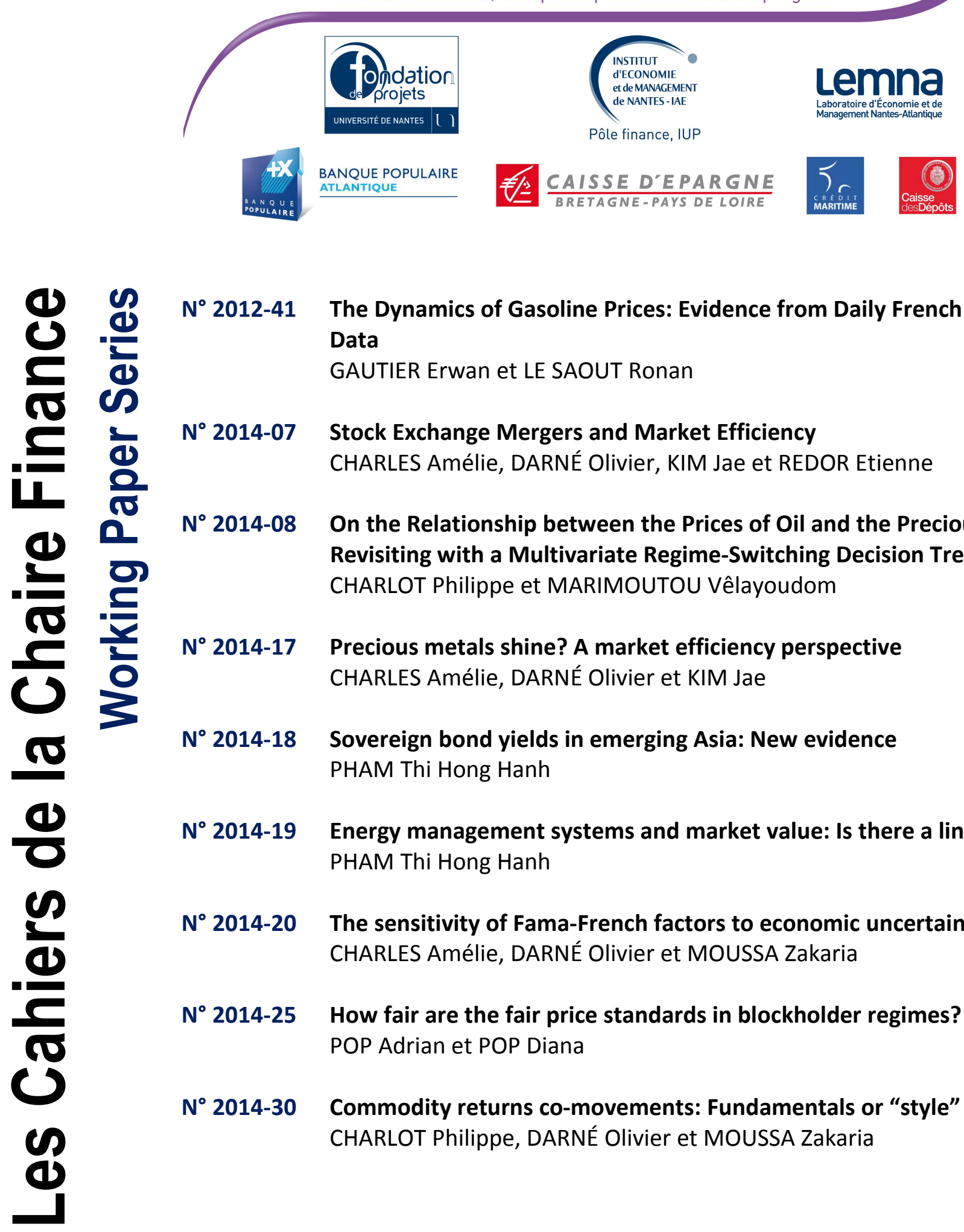

N²012-41 The Dynamics of Gasoline Prices: Evidence from Daily French Micro Data

GAUTIER Erwan et LE SAOUT Ronan

$N^{\circ}$ 2014-07 Stock Exchange Mergers and Market Efficiency

CHARLES Amélie, DARNÉ Olivier, KIM Jae et REDOR Etienne

$\mathbf{N}^{\circ}$ 2014-08 On the Relationship between the Prices of Oil and the Precious Metals:

Revisiting with a Multivariate Regime-Switching Decision Tree

CHARLOT Philippe et MARIMOUTOU Vêlayoudom

$N^{\circ}$ 2014-17 Precious metals shine? A market efficiency perspective CHARLES Amélie, DARNÉ Olivier et KIM Jae

$\mathbf{N}^{\circ}$ 2014-18 Sovereign bond yields in emerging Asia: New evidence PHAM Thi Hong Hanh

$N^{\circ}$ 2014-19 Energy management systems and market value: Is there a link? PHAM Thi Hong Hanh

$\mathrm{N}^{\circ}$ 2014-20 The sensitivity of Fama-French factors to economic uncertainty CHARLES Amélie, DARNÉ Olivier et MOUSSA Zakaria

$N^{\circ}$ 2014-25 How fair are the fair price standards in blockholder regimes? POP Adrian et POP Diana

$N^{\circ}$ 2014-30 Commodity returns co-movements: Fundamentals or "style" effect? CHARLOT Philippe, DARNÉ Olivier et MOUSSA Zakaria 